UNIVERSIDADE DE SÃO PAULO

INSTITUTO DE GEOCIÊNCIAS

\title{
FÓSSEIS EM MICRITOS QUATERNÁRIOS DA SERRA DA BODOQUENA, BONITO-MS E SUA APLICAÇÃO EM ESTUDOS PALEOAMBIENTAIS
}

GISELLE UTIDA

Orientador: Prof. Dr. Setembrino Petri

DISSERTAÇÃO DE MESTRADO

Programa de Pós-Graduação em Geoquímica e Geotectônica

São Paulo

2009 
“Tudo que acontece tem seu lado bom. Toda mudança é para melhor.” “No fim tudo dá certo...” Fernando Sabino 


\section{AGRADECIMENTOS}

Agradeço a todos que estiveram envolvidos neste trabalho sem exceção. Ao CNPq pelo financiamento do Projeto: Geologia e Paleontologia das Tufas Calcárias da Serra da Bodoquena, Mato Grosso do Sul (Proc. 479500/2007-0) e pela bolsa de mestrado. Ao IPHAN pela autorização de coleta de amostra no Porto de Corumbá através do Ofício n²84/GAB18º'SR/IPHAN-MS de 29 de agosto de 2008.

Ao Professor Doutor Setembrino Petri, exemplo a ser seguido de profissional dedicado e perseverante, sempre disposto a mais um projeto, pela orientação. Ao Professor Doutor Paulo César Boggiani por toda ajuda, campos e dedicação ao Projeto.

Ao meu amigo de campo Emiliano Castro de Oliveira, pelos conselhos geológicos, carga de campo, furo de trado e toda ajuda prestada.

Aos proprietários e funcionários das áreas estudadas, Mineração Calcário Xaraés da Fazenda São Geraldo, Fazenda Cachoeiras do Mimoso, Balneário Cabeceira do Betione, Balneário Pôr-do-Sol, Balneário Municipal Prudente Corrêa, Camping Poliana, Ilha do Padre, Praia da Figueira, ao Hotel Muito Bonito, Restaurante Tapera e a Prefeitura de Bonito.

Aos funcionários e professores do Instituto de Geociências dos laboratórios de Sedimentologia “Armando Coimbra”, Micropaleontologia “Setembrino Petri”, Preparação de amostras, Isótopos estáveis, Difratometria de Raio-X, Fluorescência de Raio-X, Paleobiologia, Microscopia Eletrônica de Varredura e Coleção de Fósseis.

Aos meus amigos da pós-graduação do Instituto de Geociências da USP, em especial a Evelyn Ap. M. S. Bizan, Guilherme R. Romero, Felipe van Enck Meira, Darciléa F. Castro, Felipe T. Figueiredo, Eline A. S. Barreto, Gabiella T. Fontaneta e Renato Kahwage da graduação em Geociências.

Aos Professores Wânia Duleba, Thomas R. Fairchild, Juliana Leme, Raphael Hypólito, Marcello Simões, Ivo Karman, Francisco W. da Cruz Junior, Paulo C. F. Giannini e William Sallun-Filho do Instituto Geológico.

A minha primeira orientadora na paleontologia Patrícia de Souza Cristalli, pelos meus trabalhos iniciais, por me ajudar nos estudos para a pós-graduação e pela amizade. 
A toda minha família pela confiança e ajuda, em especial aos meus pais, Flavio e Priscila, e padrinhos, Meire e Valdir. Ao meu namorado Rogerio Alves Rodrigues pela compreensão nos momentos difíceis, a distância durante os trabalhos de campo, o carinho e a confiança.

As minhas amigas Débora Clivati, Mariana Silva Gomide, Tatiana Mieko Tsumura, Luciane Maria Bicudo, Edione Sousa Moura e Paula Reis Matos pela amizade, por acreditarem em mim, sempre enviando mensagens positivas. 


\section{RESUMO}

O município de Bonito e arredores em Mato Grosso do Sul apresentam atrações turísticas relacionadas a diversos tipos de depósitos carbonáticos quaternários, que formam cachoeiras, barragens naturais e tornam as águas de turbidez quase nula. A área está inserida no Parque Nacional da Serra da Bodoquena e na Reserva da Biosfera do Pantanal (UNESCO). As tufas calcárias são rochas porosas formadas pela precipitação do carbonato de cálcio em água doce e podem conter diversos tipos de fósseis. Apresentam-se sob a forma de cachoeiras, barragens e sedimentos lacustres que formam depósitos micríticos inconsolidados, descritos dentro da Formação Xaraiés. Os micritos são extensos e relativamente espessos em toda a região. Contudo, a maior parte das ocorrências está intemperizada, parcialmente erodida e distribuída em áreas limitadas. O presente estudo foca a caracterização paleontológica, granulométrica e geoquímica (elementos maiores, menores, traços e isótopos de carbono e oxigênio), através de levantamento de detalhe dos micritos da área da Mineração Calcário Xaraés, em Bonito (MS). As amostras foram obtidas por furo de trado, coleta de amostras superficiais e de bloco decimétrico orientado para estudo tafonômico, complementado com investigação de campo e amostragem de algumas áreas na Serra da Bodoquena, Pantanal e Corumbá. Os micritos da Mineração Calcário Xaraés, são depósitos lacustres e podem ser descritos em três eventos: 1: base afossilífera, oncólitos, argilominerais e dados isotópicos marcam um período de maior umidade; 2: ostracodes, algas caráceas e gastrópodes fósseis que colonizaram este estágio e a baixa variação dos dados isotópicos sugerem um período estável; 3: gastrópodes de água doce resistentes a ressecamento colonizaram esta etapa, em associação com os dados isotópicos sugerem processos alternados de evaporação e umidade. O topo da seção estudada é marcada por evaporação total da água do lago, morte em massa do gastrópode Biomphalaria e instalação do gastrópode Idiopyrgus. A ausência de estruturas sedimentares, orientação, seleção e fragmentação dos bioclastos e o empacotamento fraco a disperso e feições de alteração dos bioclastos por tempo de exposição na interface água-sedimento denotam condições estáticas do ambiente durante o processo final de deposição. Estas características também sugerem abastecimento do lago por águas subterrâneas, pois produzem menor taxa de alteração dos bioclastos e manutenção das condições químicas da água, como demonstrado pela homogeneidade dos dados geoquímicos. Outros depósitos estudados de micritos também apresentam resultados semelhantes. Há forte presença de indivíduos do gênero Biomphalaria e da Família Hydrobiidae nos depósitos. Dados de campo mostram os depósitos de tufas calcárias na região com extensão maior que as registradas, ocorrendo principalmente próximos aos leitos dos rios atuais, que os dissolvem nos períodos chuvosos. Os depósitos de tufas calcárias da Serra da Bodoquena, principalmente os micríticos, provavelmente foram formados nos últimos 10.000 anos, indicando período mais quente e seco que o atual. Os últimos 2.700 na região podem ser caracterizados por aumento da umidade, extinção dos depósitos micríticos e instalação dos depósitos de tufas de cachoeira e barragens.

PALAVRA-CHAVE: micritos, Serra da Bodoquena, gastrópodes, ostracodes 


\section{ABSTRACT}

Bonito town and surrounding areas in Mato Grosso do Sul state are tourist attractions related with many quaternary carbonate deposits which form waterfalls, dams and render almost zero turbidity waters. That area is part of the National Park of Bodoquena Range and Pantanal Biosphere Reserve (UNESCO). Calcareous tufa are porous rocks formed by calcium carbonate laid down in freshwaters containg a great variety of fossils. They were presented in form of waterfalls, dams and lacustrine sediments, forming unconsolidated micritic deposits, being part of the Xaraés Formation. Micritic deposits are extensive and thick in whole area. Most of the deposits are weathered, partly eroded and distributed in restricted areas. The present study focuses on paleontological, granulometric, and geochemical (major, minor and trace elements, carbon and oxygen isotopes) data. The micritic deposits of Calcário Xaraés Mine in Bonito (MS) are detailed studied. Samples were obtained by auger drilling, also in outcrops area and one orientated centimetric indeformed block for taphomic study. The research was complemented with field study and sampling in the Bodoquena Range, Pantanal and Corumbá. Calcário Xaraés Mine’ micrites are lacustrine deposits. We described through three events: 1: their base does not contain fossils, but bears oncoids, clayminerals. Isotope data point to a wetter period, 2: ostracods, charophytes and gastropods fossils colonized this episode and homogeneity of isotope data suggest a stable event, 3: freshwater gastropods endured scarce water conditions so colonized the area. The isotope data then was varied suggesting alternated periods of evaporation and humidity. Total water lake evaporation resulted in the mass death of the Biomphalaria gastropod and consequent with diffusion of Idiopyrgus gastropod. Absence of sedimentary structures, bioclastic orientation, selection and fragmentation, weak to dispersal packing bioclast and bioclastic alteration features, are indications of long durantion in the water-sediment interface. These features suggest environmental static conditions during the final deposition. These features also suggest groundwater supplies to the lake, leading to less bioclastic alteration, and maintaing chemical water conditions, such as homogeneity of geochemical data. Other studied micritic deposits show almost the same results. There is strong presence of gastropod Biomphalaria and Hydrobiidae Family on these deposits. Field data show calcareous tufa deposits with an extension larger than the studied area, occurring mainly next to the rivers, which dissolve micritic in the rainy period. Bodoquena Range calcareous tufa deposits, mainly micritic sediments, probably were formed in the last 10.000 years, indicating a hotter and drier period than nowadays. The last 2.700 years in this region can be characterized by humidity increase, micritic deposits extinctions and installation of waterfalls and dams tufa depositions.

KEY-WORDS: micrites, Bodoquena Range, gastropods, ostracods 


\section{LISTA DE FIGURAS}

Figura 01 Distribuição dos carbonatos quaternários sobre a Faixa de dobramentos Paraguai, segundo a classificação de Boggiani \& Coimbra (1995). Modificado de Boggiani \& Coimbra, 1995.

Figura 02 Esquema geológico da Faixa Paraguai. Extraído de Boggiani \& Alvarenga (2004).......

Figura 03 Seção tipo da Formação Xaraiés na Escadinha da XV, Corumbá, MS.

Figura 04 Calcários da região matogrossense segundo Boggiani \& Coimbra (1995). A) Calcários do Pantanal do Miranda, Estrada Parque Pantanal Sul, MS. B) Tufa de cachoeira no Rio Formoso, Bonito, MS

Figura 05 Depósito de micritos inconsolidados. Mineração Calcário Xaraés, Bonito, MS...

Figura 06 Área alagada próxima às margens do Rio Formoso, remansos com grande crescimento de algas caráceas. Foto: Laboratório de Sedimentologia Professor Armando Coimbra, janeiro de 1995, a partir da esquerda Professor Paulo. C. Boggiani e Professor Armando M. Coimbra

Figura 07 Gêneros e espécies de gastrópodes encontrados nos depósitos calcários quaternários da Serra da Bodoquena. a) Pomacea canaliculata. b) Bulimulus aungustus. c) Biomphalaria. d) Idiopyrgus souleyetianus. e) Megalobulimulus......

Figura 08 Vista aérea do depósito de micritos da Mineração Calcário Xaraés. Fonte: Google, 2009

Figura 09 A) Localização do município de Bonito no Estado do Mato Grosso do Sul. B) Localização da Mineração Calcário Xaraés (Geologia modificada de Araújo et al., 1982).

Figura 10 Coleta do bloco orientado em micritos inconsolidados da lavra da Mineração Calcário Xaraés. Explicação no texto..

Figura 11 Bloco analisado no estudo tafonômico. a) representação do bloco em planta. b) representação do bloco em perfil. c) Exemplo de trabalho no bloco. d) Face norte e lateral direita do bloco.

Figura 12 Variáveis morfológicas analisadas dos gastrópodes do gênero Pomacea. Para Biomphalaria Sph é a altura da abertura. Baseado em Estebenet, A. L. (1998)...

Figura 13 Perfil obtido com informações coletadas em campo.

Figura 14 Oncólitos encontrados na base da lavra de carbonatos da Mineração Calcário Xaraés. O oncólito indicado pela seta apresenta crescimento concêntrico, evidenciando transporte durante seu crescimento, ao contrário do oncólito a sua direita......

Figura 15 Mineração Calcário Xaraés, Faz. São Geraldo. A) Visão geral da área de coleta na mineração. B) Corte amostrado representado em uma coluna amarela na figura A. C) Amostragem por método de tradagem, local representado por um círculo vermelho na figura A, notar calcário mais claro proveniente da tradagem sobre calcário mais escuro da porção exposta. D) Amostragem em campo, as amostras coletadas representam o perfil à direita, $\mathrm{C}$ : corte, $\mathrm{T}$ : Tradagem.

Figura 16 Lavra da Mineração Calcário Xaraés. A) Exposição no mesmo local de coleta anterior, apenas com maior profundidade. B) Área sobre o depósito depois de retirada da vegetação.

Figura 17 Micritos intemperizados sobre argila vermelha. A) Micritos de antiga área de exploração da Mineração "Calcário Xaraés”. Círculo vermelho indica pincel e posição de B) Detalhe da área da figura A....

Figura 18 A) Área de coleta. Visão do afloramento em processo de erosão e decomposição devido ao domínio de vegetação, notar o crescimento de raízes. B) Gastrópodes e bivalves encontrados.

Figura 19 Área de coleta do ponto 06, Cachoeiras do Mimoso. A) Rocha carbonática aflorante. 
B) Gastrópodes, pontos brancos, são encontrados neste afloramento bem incrustados nas tufas.

Figura 20 Depósito do ponto 07, Rio Seputa. A) Sumidouro do Rio Seputa. Notar nas figuras A, $\mathrm{B}$ e $\mathrm{C}$ as margens sem vegetação com a rocha exposta. Em períodos de chuva ela deve ficar coberta pela água. C) Círculo vermelho indica área de coleta. D) Macroalgas filamentosas produzem bolhas de gás carbônico que são recobertas pelo carbonato..

Figura 21 Rio Campina. As margens erodidas expõem gastrópodes em um depósito calcário cinzento. Círculo vermelho indica área de coleta em detalhe em B) Acima e a esquerda da figura um gastrópode.

Figura 22 Antiga mineração de carbonato. A) Solo de carbonato exposto, 07TUF16B. B) Detalhe do depósito com gastrópodes. C) Calcário compacto e denso na mesma área, 07TUF16D.

Figura 23 A e B) Área de remanso do Rio Formoso. Em B a elipse amarela define a área onde são encontradas algas. C) Área de fluxo após o remanso, a direção da corrente de água é da direita para a esquerda. D) Gastrópode destacado por um clipe, ao redor nódulos carbonáticos que recobrem todo o solo na figura $\mathrm{C}$

Figura 24 A) Tufa de cachoeira fóssil próximo a queda atual à esquerda (seta). B) Detalhe do afloramento. C) Tufas calcárias fósseis com vestígios de vegetais, áreas mais escuras são folhas. Detalhe da figura B.

Figura 25 Caverna formada por tufas calcárias. A) Caverna formada por tufas calcárias na Fazenda do Rio Mimoso. B) Detalhe do interior da caverna......

Figura 26 Depósito de tufas calcárias fósseis. Não há gastrópodes nesta área, apenas folhas.........

Figura 27 Rio Betione. A) Queda de água, notar o fluxo e o volume de água. B) Queda de água com folhas fixas na porção superior da queda. C) Tufa calcária com aspecto rugoso e esverdeado. D) Folhas ainda com matéria orgânica recobertas por carbonato.

Figura 28 Gastrópodes encontrados no primeiro ponto do Rio Betione. A) Gastrópodes atuais mortos nas margens do rio. B) Solo expondo gastrópodes em antigos depósitos de carbonato

Figura 29 Rio Betione no ponto 13. A) Queda de água. B) Rio após uma das quedas de água. Notar o volume de água e vegetação......

Figura 30 Balneário Pôr do Sol. Área com gastrópodes. A) Corte próximo a margem com exposição de gastrópodes. B) Gastrópode destacado com círculo encontrado no local...

Figura 31 Balneário Municipal Prudente Corrêa. A e B) O rio possui grande volume de água, mas pouco fluxo. C) Calcário com gastrópodes.

Figura 32 Rio Formoso no Camping Poliana. A) Queda de água. B) Após a queda grande volume de água e pouco fluxo. C) Às margens pequena profundidade e águas límpidas. D) Âs margens crescem macroalgas filamentosas.

Figura 33 Antigos depósitos de tufas calcárias às margens do Rio Formoso. A) Tufa calcária semelhante aos de quedas de água. B) Depósito contendo gastrópodes e tubos calcários.

Figura 34 Detalhes do Rio Formoso na Ilha do Padre A) Notar grande volume de água e pouco fluxo. B) Macroalgas filamentosas. C) Gastrópodes mortos no fundo próximos às margens. D) Ovos de gastrópodes fixos à vegetação à margem do rio destacados em vermelho. E) Ovos de gastrópodes fixos à madeira da ponte, provavelmente Pomacea, pela coloração e tamanho. Escala aproximada de $1 \mathrm{~cm}$.

Figura 35 Rio Formoso. Sistema com maior fluxo de água

Figura 36 Rio Formoso. A, B e C) Área de maior fluxo do Rio Formoso. D) Área de remanso. Ocorrência de estromatólitos recentes no leito do rio.

Figura 37 Micrito consolidado encontrado as margens do Rio Formozinho. Gastrópode do gênero Pomacea indicado pela seta azul e alteração do carbonato indicada pela seta 
amarela.

Figura 38 Tufas calcárias nas margens do Rio Formozinho. A) Localização do micrito consolidado, seta amarela, e do gastrópode, seta vermelha, no solo representado em B) Gastrópodes do gênero Pomacea em solo às margens do Rio Formozinho.

Figura 39 Rio Formoso. A) Praia da Figueira. B) Rio Formoso C) Margem com diversas oviposições do gênero Pomacea. D) Detalhe dos ovos de Pomacea.

Figura 40 A) Leito do rio com baixa turbulência. B) Tufas de cachoeira localizadas ao fundo da imagem A. C) Panorâmica de parte da planície acima do leito do Rio do Prata. O rio encontra-se atrás da casa entre a vegetação.....

Figura 41 Rio Mimoso represado neste ponto. A) Acúmulo de sedimentos e matéria orgânica causado pelo represamento. B) Local da barragem.

Figura 42 Rio Mimoso. A) "Equipamento" para retirada de água do rio. B) Tufa calcária de cachoeira provavelmente extinta pelo represamento do rio.

Figura 43 A) Área exposta de sedimentos próxima à coleta de água. A seta superior indica localização da figura 43 B, a inferior a localização da figura 43 C, logo abaixo, a água está presente. B) Conchas de moluscos na área exposta. C) Seixos expostos na base do afloramento. Imagem sem escala, não foi possível alcançar o local.

Figura 44 Córrego da Olaria. A) Porção represada do córrego por tufas de barragem. B) Porção com tufas de cachoeira

Figura 45 Córrego Pitangueiras. A) Leito do rio entalhando o depósito de micritos e tufas no leito. B) Micritos expostos às margens do rio, a esquerda tufa fitohermal recoberta por musgos, indicada pela seta, e a direita micrito com conchas de moluscos

Figura 46 Depósitos próximo ao Córrego Pitangueiras. A) Afloramento de micritos detríticos sobre argila de cor vermelha a montante do rio. Seta vermelha indica posição do micrito detrítico. B) Micrito detrítico

Figura 47 Córrego Pitangueiras. Porção a jusante do ponto 30 marcado com GPS. Notar que o rio entalha a argila e não carbonatos...

Figura 48 Localização da nascente do Rio Sucuri. A linha pontilhada se refere ao trecho percorrido. Fonte: Google, 2009.

Figura 49 Rio Sucuri, Bonito, MS. A) Nascente do Rio Sucuri. B) Detalhe da água aflorando. C) Acúmulo de conchas no leito do rio, a seta indica o sentido da corrente. D) Porção de sedimento solto com vegetação e muitas conchas de gastrópodes. E, F) População de algas caráceas no Rio Sucuri. G) Micritos endurecidos no leito do rio. H) Detalhe dos micritos no leito do rio...

Figura 50 Lente do Pantanal do Miranda. A) Visão geral do depósito. B) Detalhe da rocha com conchas do gênero Pomacea. C) Detalhe do afloramento.

Figura 51 Lente do Pantanal do Miranda. A) Vista do afloramento da Lente. B) Detalhe da rocha com gastrópode.

Figura 52 Exemplares de gastrópode do gênero Marisa encontrados em uma das Lentes Calcárias do Pantanal do Miranda. As duas primeiras conchas representam o mesmo indivíduo.

Figura 53 A) Afloramento em frente ao posto de abastecimento de barcos no porto de CorumbáMS. B) Detalhe do depósito. C) Amostra com prováveis fragmentos de moluscos em um intraclasto. D) Detalhe da porção com prováveis fragmentos de moluscos.

Figura 54 Gráfico evaporação x precipitação em Campo Grande-MS das médias mensais de 1961 a 1990 seguindo as normas climatológicas do Instituto Nacional de Meteorologia. Extraído de: IMET - Instituto Nacional de Meteorologia......

Figura 55 Teor de carbonato dos depósitos da Mineração Calcário Xaraés. a) Teor de carbonato da Mineração Calcário Xaraés, o ponto no gráfico em 0 representa a base do depósito, e b) Os demais depósitos estudados. 
Figura 56 Gráficos obtidos da análise multivariada dos elementos composicionais do perfil da Mineração Calcário Xaraés. a) Autovalores dos componentes principais. b) Distribuição dos elementos composicionais nos $1^{\mathrm{a}}$ e $2^{\mathrm{a}}$ componentes principais. c) Distribuição das observações e dos elementos composicionais. d) Relação entre o $1^{\mathrm{a}} \mathrm{e}$ $2^{\mathrm{a}}$ componente principal. Figura 55 - Análise de agrupamento. a) Análise de agrupamento do perfil da Mineração Calcário Xaraés. b) Observações relativas aos pontos no perfil. $5,16 \mathrm{~m}$ equivale ao topo do depósito. Exposição: amostras obtidas em porção expostas. Tradagem: amostras obtidas por coleta através de furo de trado..........

Figura 57 Análise de agrupamento. a) Análise de agrupamento do perfil da Mineração Calcário Xaraés. b) Observações relativas aos pontos no perfil. $5,16 \mathrm{~m}$ equivale ao topo do depósito. Exposição: amostras obtidas em porção expostas. Tradagem: amostras obtidas por coleta através de furo de trado.

Figura 58 Gráficos obtidos da análise multivariada dos elementos composicionais do perfil da Mineração Calcário Xaraés sem os pontos referentes à base. a) Autovalores das componentes principais. b) Distribuição dos elementos composicionais nas $1^{\mathrm{a}}$ e $2^{\mathrm{a}}$ componentes principais. c) Distribuição das observações e dos elementos composicionais. d) Relação entre a $1^{\mathrm{a}}$ e $2^{\mathrm{a}}$ componente principal

Figura 59 Análise de agrupamento. a) Análise de agrupamento do perfil da Mineração Calcário Xaraés sem os três pontos referentes à base. b) Observações relativas aos pontos no perfil. 5,16m equivale ao topo do depósito. Exposição: amostras obtidas em porção expostas. Tradagem: amostras obtidas por coleta através de furo de trado.

Figura 60 Gráficos obtidos da análise multivariada dos elementos composicionais do perfil da Mineração Calcário Xaraés sem as três amostras da base e os demais pontos. a) Autovalores dos componentes principais. b) Distribuição dos elementos composicionais no $1^{\circ}$ e $2^{\circ}$ componentes principais. c) Distribuição das observações e dos elementos composicionais. d) Relação entre o $1^{\circ}$ e $2^{\circ}$ componente principal.

Figura 61 Análise de agrupamento do perfil da Mineração Calcário Xaraés sem os três pontos da base e os demais pontos estudados. a) Análise de agrupamento dos micritos do perfil da Mineração Calcário Xaraés sem os três pontos da base e demais pontos estudados. b) Observações relativas aos pontos. 5,16m equivale ao topo do depósito. Exposição: amostras obtidas em porção expostas. Tradagem: amostras obtidas por coleta através de furo de trado.

Figura 62 Isótopos de Carbono e Oxigênio da Mineração Calcário Xaraés

Figura 63 Isótopos de Carbono e Oxigênio do perfil da Mineração Calcário Xaraés. Resultados de isótopos de carbono e oxigênio para análise em micritos e em gastrópodes. A elipse marca os micritos com exceção da base. Os gastrópodes analisados foram coletados no perfil de acordo com a legenda. A base do depósito é representada em $0 \mathrm{~m}$.

Figura 64 Comparação dos isótopos de carbono e Oxigênio dos depósitos da Serra da Bodoquena. Resultados de isótopos de carbono e oxigênio para análise em micritos e moluscos.

Figura 65 Distribuição de $\delta^{13} \mathrm{C}_{\mathrm{V}-\mathrm{PDB}} \%$ e e $\delta^{18} \mathrm{O}_{\mathrm{V}-\mathrm{PDB}} \%$ para os depósitos micríticos e moluscos encontrados nestes calcários.

Figura 66 Gastrópodes encontrados na Mineração Calcário Xaraés. A, B) Pomacea. C, D) Biomphalaria. E, F) Idiopyrgus. G, H) Bulimulus...

Figura 67 Demais moluscos encontrados nos depósitos. a) Visão interna e externa de Diplodon. b) Dois indivíduos da Família Thiaridae. c) Visão dorsal e ventral de Drepanotrema. d) Visão ventral e dorsal de Happia. e) Visão interna de Psidium. f) Indivíduo do gênero Acrobis.

Figura 68 a) Gastrópode do gênero Pomacea classificado como friável na análise tafonômica. Notar as camadas da concha. b) Porção da camada 4 com empacotamento de bioclastos considerado denso a direita, à esquerda empacotamento disperso. Notar também a incrustação nos gastrópodes.

Figura 69 Análise tafonômica em planta. Imagens das camadas analisadas do bloco orientado de 
micritos da Mineração Calcário Xaraés. Escala $5 \mathrm{~cm}$

Figura 70 Exemplos de assinaturas tafonômicas estudadas. a) A primeira concha é atual e possui coloração característica. A segunda concha, apesar de atual, esteve exposta a ações intempéricas apresentando perda de cor. A terceira concha é fóssil, coletada no ponto 04, possui algumas incrustações e está completamente branca. b) Concha atual com incrustações carbonáticas semelhantes às encontradas nos fósseis, como a da terceira concha em a.

Figura 71 Análise do bloco em planta. a) Empacotamento do depósito. b) Orientação dos bioclastos. c) Textura dos bioclasto. d) Coloração dos bioclastos. e) Fragmentação dos bioclastos...

Figura 72 Folhas com incrustação carbonática (seta inferior) e sem incrustação carbonática (seta superior), presas em troncos dentro do leito do Rio Betione, Bodoquena-MS..

Figura 73 Classificação de alteração dos bioclastos obtidos do bloco orientado da análise em planta. a) Alteração dos bioclastos. b) Posição da alteração nos bioclastos.

Figura 74 Fragmentação dos bioclastos na análise em planta do bloco orientado. a) Porcentagem de bioclastos fragmentados de acordo com a posição. b) Porcentagem de fragmentação de acordo com o taxon. c) Porcentagem da posição de fragmentação de acordo com o taxon...

Figura 75 Observações de acordo com o taxon dos bioclastos obtidos do bloco orientado da análise em planta. a) Porcentagem de friabilidade de acordo com o taxon. b) Porcentagem de condição dos bioclastos de acordo com o taxon. c) Porcentagem da textura de acordo com o taxon. d) Porcentagem do tipo de coloração de acordo com o taxon. e) Porcentagem da orientação dos bioclastos de acordo com o taxon...

Figura 76 Distribuição da altura $(\mathrm{SH})$ pela largura $(\mathrm{SW})$ dos bioclastos obtidos do bloco orientado estudado em planta.

Figura 77 Face norte do bloco orientado após a retirada dos horizontes para análise tafonômica. Escala $5 \mathrm{~cm}$......

Figura 78 Análise do bloco em perfil. a) Empacotamento do depósito. b) Orientação dos bioclastos. c) Textura dos bioclasto. d) Coloração dos bioclastos. e) Fragmentação dos bioclastos...

Figura 79 Classificação de alteração dos bioclastos obtidos da análise do bloco orientado analisado em perfil. a) Alteração dos bioclastos. b) Posição da alteração nos bioclastos.

Figura 80 Fragmentação dos bioclastos na análise em perfil do bloco orientado. a) Porcentagem de bioclastos fragmentados de acordo com a posição. b) Porcentagem de fragmentação de acordo com o Táxon. c) Porcentagem da posição de fragmentação de acordo com o Táxon.

Figura 81 Distribuição da altura (SH) pela largura (SW) dos bioclastos obtidos da análise em bloco orientado estudado em perfil...

Figura 82 Observações de acordo com o taxon dos bioclastos estudados em perfil no bloco orientado. a) Porcentagem de friabilidade de acordo com o taxon. b) Porcentagem de condição dos bioclastos de acordo com o taxon. c) Porcentagem da textura de acordo com o taxon. d) Porcentagem do tipo de coloração de acordo com o taxon. e) Porcentagem da orientação dos bioclastos de acordo com o taxon.

Figura 83 Número de voltas das conchas para Idiopyrgus, Hydrobiidae e Pomacea obtidos da amostra orientada em planta..

Figura 84 Médias obtidas dos gastrópodes analisados no bloco orientado em planta e perfil. A proporção entre os gastrópodes foi mantida.

Figura 85 Gráficos para as razões biométricas analisadas dos indivíduos do gênero Pomacea obtidos na análise do bloco em planta.

Figura 86 Relações morfológicas de Pomacea, Idiopyrgus, Biomphalaria e para a Família 
Hydrobiidae obtidos na análise do bloco orientado em planta.

Figura 87 Razões de largura da concha (SW) pela altura da concha (SH) e largura da abertura (AW) pela altura da concha para indivíduos do gênero Idiopyrgus obtidos na análise do bloco orientado em planta.

Figura 88 Razões de largura da concha (SW) pela altura da concha (SH) e largura da abertura (Sph) pela altura da concha para indivíduos do gênero Biomphalaria obtidos na análise do bloco orientado em planta.

Figura 89 Razão largura da concha (SW) pela altura da concha (SH) para indivíduos da Família Hydrobiidae obtidos na análise do bloco orientado em planta..

Figura 90 Frequências da altura dos gêneros Pomacea e Idiopyrgus, e diâmetro de Biomphalaria quando analisados em planta na amostra

Figura 91 Número de voltas das conchas para Idiopyrgus e Pomacea obtidos no bloco orientado estudado em perfil.

Figura 92 Gráficos para as razões biométricas dos gastrópodes obtidos no bloco orientado analisado em perfil.

Figura 93 Relações morfológicas das conchas de Pomacea, Idiopyrgus e Biomphalaria obtidas no bloco orientado analisado em perfil.....

Figura 94 Razões de largura da concha (SW) pela altura da concha (SH) e largura da abertura (AW) pela altura da concha do gênero Idiopyrgus obtidos no bloco orientado estudado em perfil.

Figura 95 Razões de largura da concha (SW) pela altura da concha (SH) e largura da abertura (Sph) pela altura da concha para indivíduos do gênero Biomphalaria obtidos no bloco orientado analisado em perfil.

Figura 96 Frequências da altura dos gêneros Pomacea e Idiopyrgus, e diâmetro de Biomphalaria, quando analisados em perfil na amostra.

Figura 97 Representação do total de moluscos encontrados na análise tafonômica em planta do bloco orientado da Mineração Calcário Xaraés.

Figura 98 Proporção de taxa por camada obtidas no bloco analisado em planta.

Figura 99 Representação do total de moluscos encontrados na análise tafonômica em perfil do bloco da Mineração Calcário Xaraés.

Figura 100 Proporção de taxa por camada do bloco analisado em perfil..

Figura 101 Orientação dos gastrópodes na Mineração Calcário Xaraés. a) Histograma da orientação dos gastrópodes na análise em planta, $0^{\circ}$ representa o Norte e o vetor em preto indica o vetor médio. b) Histograma da orientação dos gastrópodes na análise em perfil, $0^{\circ}$ representa o Topo do perfil e o vetor em preto indica o vetor médio...........

Figura 102 Esquema do bloco analisado em planta e em perfil com os dados do vetor médio de cada análise.

Figura 103 Impressões musculares utilizadas para identificar os ostracodes. Modificado de Van Morkhoven (1963) e Gross (2008)...

Figura 104 Ovos de ostracodes estudados por Smith (1999). a) Esferas encontradas da Formação Santana. b) Ovos recentes do ostracode Heterocypris incongruens de espécimes criados em laboratório. c) Ovos recentes do ostracode Darwinula stevensoni de espécimes criados em laboratório. Extraído de Smith (1999). d) Estruturas interpretadas como: d.1) ovo esférico de ostracode Mineração Calcário Xaraés, ponto 1,06 do perfil; d.2) ovo alongado de ostracode, depósito 14; d.3) Heliozoa, depósito 16B. Escala $10 \mu \mathrm{m}$.

Figura 105 Fungos atuais. a) Zoosporângio atual de Chytriomyces hyalinus Karling. b) Talo policêntrico com zoosporângios operculados de Nowakowskiella hemisphaerospora Shanor. Extraído de Pires-Zottarelli1 \& Rocha (2007). c) Estruturas esféricas ligadas a um pedúnculo encontradas no depósito 14 . 
Figura 106 Seções tranversais dos tipos de talos encontrados nos depósitos micríticos na planície da Serra da Bodoquena.....

Figura 107 Talos encontrados no depósito 07. Os talos apresentam os nós dos ramos, talo da direita possui parte de um girogonite.

Figura 108 Morfologia dos indivíduos do gênero Chara encontrados nos depósitos em estudo. Sem escala.

Figura 109 Índice de Shannon Weaver calculado para os fósseis da Mineração Calcário Xaraés. Elipses indicam áreas de possível modificação intempérica no depósito.

Figura 110 Concentração de fósseis no perfil da Mineração Calcário Xaraés e o índice de diversidade (H')

Figura 111 Índice de diversidade dos fósseis do perfil dos micritos da Mineração Calcário Xaraés e da Serra da Bodoquena.

Figura 112 Esquema dos resultados do conteúdo fossilífero, granulometria e isótopos obtidos para o depósito de micritos da Mineração Calcário Xaraés. 1, 2 e 3 referem-se às etapas de evolução do depósito esquematizadas na Figura 111. Mais explicações no texto

Figura 113 Hipótese de evolução do depósito da Mineração Calcário Xaraés. O volume da coluna de água é baseado na curva obtida através dos dados de isótopos de oxigênio. Explicação no texto

Figura 114 Hipótese de extinção do depósito de micritos da Mineração Calcário Xaraés a partir de análise do bloco orientado do topo do depósito. a) 1,2 e 3 Hipótese da sequência de extinção do lago. 4) Depósito da Mineração Calcário Xaraés, a imagem a esquerda mostra em vermelho uma projeção do bloco estudado ainda não extraído, e em amarelo a camada de solo descartada. À direita vista geral de uma das frentes de extração de carbonatos. Mais explicações no texto. b) Feições sedimentológicas. c) Feições bioestratinômicas. d) Feições paleoecológicas.

Figura 115 Esquema dos resultados do conteúdo fossilífero, granulometria e isótopos obtidos para os depósitos de micritos da Serra da Bodoquena. Explicações no texto

Prancha I Microfósseis encontrados na Mineração Calcário Xaraés

Prancha II Microfósseis encontrados na Mineração Calcário Xaraés 195

Prancha III Microfósseis encontrados na Mineração Calcário Xaraés

Prancha IV Microfósseis encontrados nos depósitos 04 e 06 199

Prancha V Microfósseis encontrados nos depósitos 07 e 14 ..... 201

Prancha VI Microfósseis encontrados nos depósitos 16B e 16D 


\section{LISTA DE TABELAS E QUADROS}

Tabela 01 Projeções UTM dos pontos estudados no Estado do Mato Grosso do Sul, os pontos estudados em estudados em destaque.

Tabela 02 Proporções das classes granulométricas e classificação atribuída a os sedimentos da Mineração Calcário Xaraés e demais pontos estudados segundo Trefethen (1950). Topo do perfil é 5,16m. Exposição: amostras obtidas em porção expostas. Tradagem: amostras obtidas por coleta através de furo de trado.

Tabela 03 Estatística descritiva dos dados granulométricos dos sedimentos da Mineração Calcário Xaraés

Tabela 04 Argilominerais e calcita identificados nas análises de DRX para os sedimentos da Mineração Calcário Xaraés e demais depósitos da Serra da Bodoquena. Exposição: amostras obtidas em porção expostas. Tradagem: amostras obtidas por coleta através de furo de trado.

Tabela 05 Análise da \% de contribuição dos componentes principais do perfil da Mineração Calcário Xaraés.

Tabela 0610 primeiros componentes principais gerados da análise multivariada do perfil da Mineração Calcário Xaraés

Tabela 07 Análise da \% de contribuição dos componentes principais dos micritos da Mineração Calcário Xaraés.

Tabela 088 primeiros componentes principais gerados da análise multivariada do perfil da Mineração Calcário Xaraés sem os três pontos da base.

Tabela 09 Análise da \% de contribuição dos componentes principais do perfil da Mineração Calcário Xaraés, sem as três amostras da base, e os demais pontos.

Tabela 1012 primeiros componentes principais gerados da análise multivariada dos micritos do perfil da Mineração Calcário Xaraés sem os três pontos da base e os demais depósitos estudados.

Tabela 11 Isótopos do perfil (profundidade em m) da Mineração Calcário Xaraés. Resultados para isótopo de carbono e oxigênio obtidos de micritos e de gastrópodes do gênero Pomacea. Exposição: amostras obtidas em porção expostas. Tradagem: amostras obtidas por coleta através de furo de trado.

Tabela 12 Resultados para isótopo de carbono e oxigênio obtidos de micritos, gastrópodes e bivalves em amostras dos demais depósitos estudados.

Tabela 13 Moluscos identificados durante as coletas na Serra da Bodoquena

Tabela 14 Moluscos identificados em 100g das amostras de micritos da Serra da Bodoquena.

Tabela 15 Características do sedimento retirado de cada camada do bloco orientado na análise em planta.

Tabela 16 Características do bloco orientado estudado em perfil.

Tabela 17 Análise estatística da biometria das conchas obtidas da análise do bloco orientado em planta.

Tabela 18 Razões para as variáveis biométricas analisadas obtidas das conchas da análise do bloco em planta. Tais razões aumentam em relação com crescimento da concha (Estebenet, 1998).

Tabela 19 Análise estatística da biometria das conchas obtidas do bloco orientado estudado em perfil.

Tabela 20 Razões para as variáveis biométricas dos gastrópodes obtidos no bloco orientado analisado em perfil.

Tabela 21 Índices ecológicos para os dados coletados nas camadas em planta do bloco orientado........

Tabela 22 Índices ecológicos para os dados coletados nas camadas analisadas em planta no bloco orientado. 
Tabela 23 Teste de uniformidade para as direções do ápice dos gastrópodes do bloco orientado analisados em planta e em perfil da Mineração Calcário Xaraés.

Tabela 24 Ostracodes encontrados nos depósitos de micritos. Nesta tabela são contabilizadas apenas as valvas direitas, ou esquerdas, e indivíduos inteiros, para evitar a contagem em dobro do mesmo indivíduo

Quadro 01 Variações morfológicas do gênero Chara encontrado nos depósitos de micritos da planície da Serra da Bodoquena.

Tabela 25 Ocorrências das variações morfológicas de Chara nos depósitos de micritos da planície da Serra da Bodoquena. Indet.: girogonites não identificados.

Tabela 26 Moluscos encontrados nos micritos da planície da Serra da Bodoquena.....

Tabela 27 Índices ecológicos calculados para as amostras a partir dos dados da análise de microfósseis. N-número total de indivíduos, S-número total de espécies.

Tabela 28 Datações obtidas pelo método ${ }^{14} \mathrm{C}$ para diversos tipos de tufa da Serra da Bodoquena. Idade calibrada com INTCAL04 Radiocarbon Age Calibration (2004) por Sallun-Filho et al. (2009). 1 - Sallun-Filho et al. (2009); 2 - Turq et al. (1987); 3 - Boggiani et al., (2002). Modificado de Sallun-Filho et al. (2009)..... 


\section{SUMÁRIO}

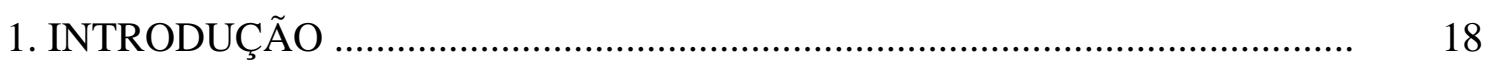

2. AS TUFAS CALCÁRIAS …................................................................... 20

2.1. Aspectos geológicos da área de estudo .................................................................... 20

2.2. Definição das tufas calcárias ............................................................................. 22

2.3. A Formação Xaraiés e os calcários quaternários da região ........................................... 24

2.4. Fósseis presentes nas tufas calcárias do Mato Grosso do Sul ....................................... 28

3. MATERIAIS E MÉTODOS DE ESTUDO ................................................. $\quad 30$

3.1. Locais de estudo ......................................................................................... $\quad 30$

3.2. Análise granulométrica e teor de carbonato ........................................................... 32

3.3. Identificação dos argilominerais e análise química e de elementos traços ....................... 33

3.4. Análises de isótopos estáveis de carbono e oxigênio ................................................. 33

3.5. Coleta e identificação dos moluscos ................................................................... 34

3.6. Análise micropaleontológica .......................................................................... 34

3.7. Identificação dos microfósseis ......................................................................... $\quad 35$

3.8. Análises tafonômicas e morfológicas ................................................................. 36

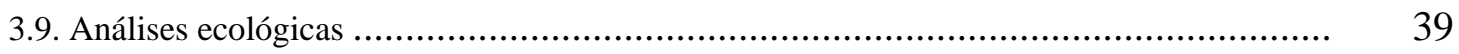

3.10 Outros enfoques estatísticos ............................................................................... 40

4. AFLORAMENTOS ESTUDADOS …........................................................ 41

4.1. Afloramentos da Serra da Bodoquena estudados em campo e laboratório ....................... 41

4.2. Afloramentos estudados em campo ................................................................. 49

4.2.1. Serra da Bodoquena ......................................................................... 49

4.2.2. Depósitos do Pantanal .............................................................................. 69

4.2.3. Depósito de Corumbá .................................................................................... 71

4.3. Considerações .............................................................................................. $\quad 72$

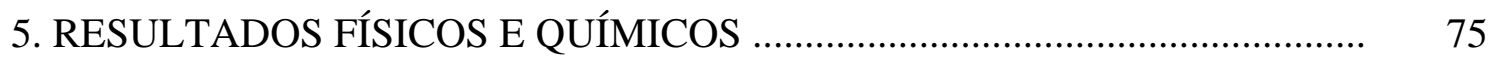

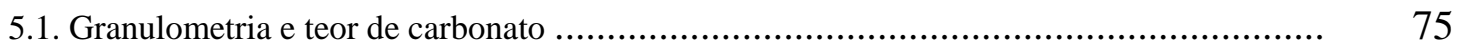

5.2. Identificação dos argilominerais ......................................................................... $\quad 77$

5.3. Análises de elementos maiores, menores e traços ................................................... 80

5.3.1. Mineração Calcário Xaraés ..................................................................... $\quad 80$

5.3.2. Micritos da Mineração Calcário Xaraés ....................................................... 83

5.3.3. Micritos da Mineração Calcário Xaraés e outros depósitos da Serra da Bodoquena.. 86

5.3.4. Considerações ..................................................................................... 89

5.4. Análise de isótopos estáveis ................................................................................ $\quad 90$

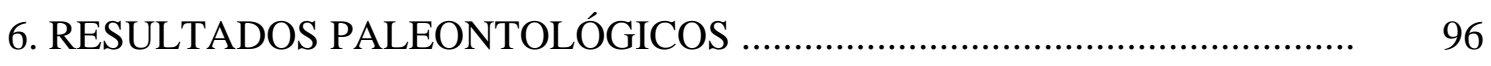

6.1. Identificação dos moluscos ........................................................................... 96

6.2. Análises tafonômicas ................................................................................... 100

6.2.1. Análise do bloco orientado em planta ........................................................ 100

6.2.2. Análise do bloco orientado em perfil ........................................................... 108

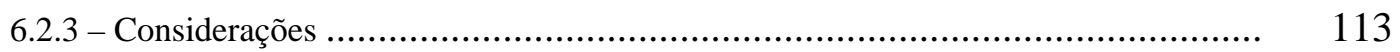

6.3. Análises morfológicas dos gastrópodes ............................................................. 114

6.3.1. Gastrópodes do bloco analisado em planta .................................................. 114

6.3.2. Gastrópodes do bloco analisado em perfil .................................................... 121 


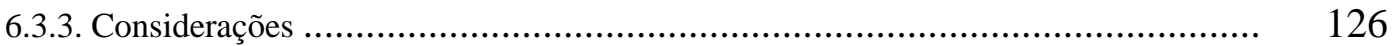

6.4. Índices ecológicos da paleofauna coletada no bloco orientado ..................................... 128

6.4.1. Índices ecológicos da paleofauna obtida na análise tafonômica em planta .............. 128

6.4.2. Índices ecológicos da paleofauna obtida na análise tafonômica em perfil ............... 129

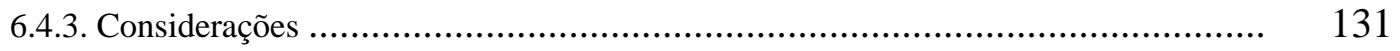

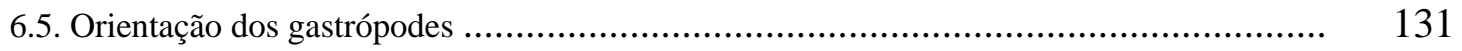

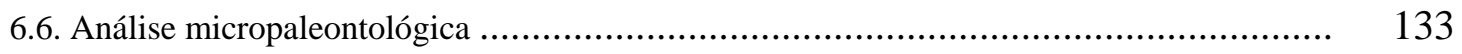

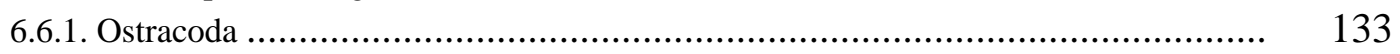

6.6.2. Estruturas esferoidais ........................................................................ 146

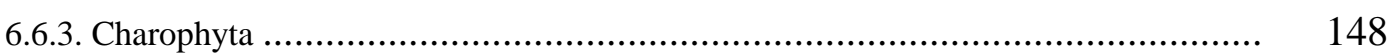

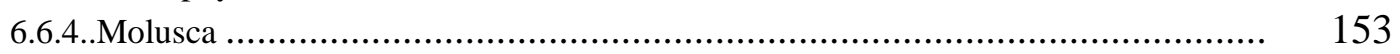

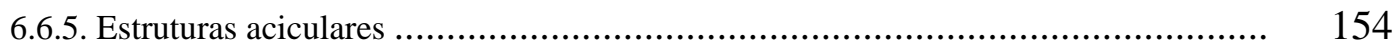

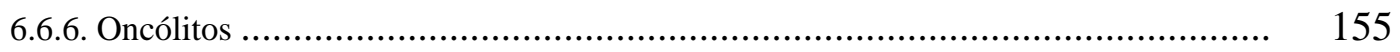

6.6.7. Índices ecológicos da paleofauna coletada na análise micropaleotológica .............. 155

6.6.8. Considerações ....................................................................................... 157

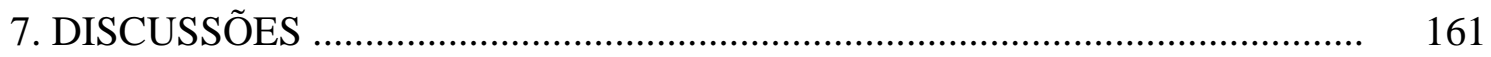

7.1. Os micritos da Mineração Calcário Xaraés ............................................................. 161

7.2. Outros depósitos de micritos da Serra da Bodoquena ................................................ 171

7.3. As tufas da Serra da Bodoquena e os depósitos do Pantanal e Corumbá ......................... 174

7.4. Idade dos depósitos de micritos da Serra da Bodoquena e as implicações ambientais ........ 175

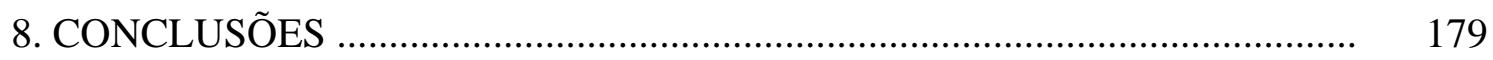

9. REFERÊNCIAS BIBLIOGRÁFICAS................................................................. 182

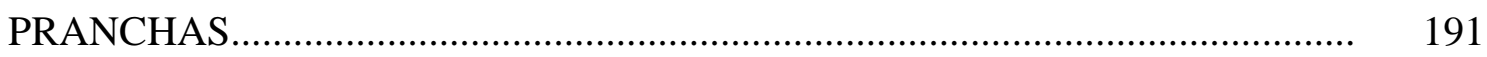

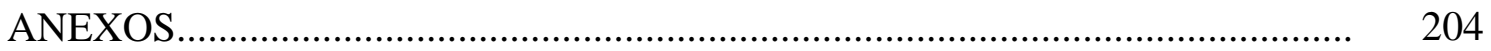




\section{INTRODUÇÃO}

Atualmente a região de Bonito no Mato Grosso do Sul é atração turística de renome internacional, motivada pela ocorrência de diversos depósitos carbonáticos quaternários, que formam cachoeiras em águas translúcidas. A área em parte está inserida no Parque Nacional da Serra da Bodoquena e faz parte da Reserva da Biosfera do Pantanal (UNESCO).

Estas áreas incluem os depósitos micríticos onde ocorrem moluscos e outros fósseis. Alguns desses depósitos são explorados economicamente para uso na agricultura e ração animal.

Estes depósitos micríticos são intemperizados pelos rios fornecendo carbonatos para deposições atuais, especialmente as do tipo de cachoeiras, principais atrativos procurados pelos turistas.

Em Bonito ocorrem diversos depósitos carbonáticos quaternários como estes, contendo fósseis de moluscos, ostracodes e algas caráceas (Utida et al., 2008). Estes depósitos foram pela primeira vez identificados por Almeida (1945), e posteriormente estudados por Turq et al. (1987); Roque (1999); Boggiani \& Coimbra (1995) e Boggiani et. al. (2002), mas estudos pormenorizados dos fósseis foram iniciados por Utida et al. (2007) e Utida et al. (2008).

Os micritos são extensos e relativamente espessos em toda a região de Bonito. Contudo, a maior parte das ocorrências está intemperizada, parcialmente erodida e distribuída em áreas limitadas. Felizmente, os trabalhos de extração de micritos inconsolidados pela Mineração Calcário Xaraés, à margem do Rio Mimoso, à cerca de 19 km ao Sul da cidade de Bonito, forneceu uma oportunidade impar para este estudo.

O principal objetivo desta pesquisa foi realizar a caracterização paleontológica, geoquímica (elementos maiores, menores, traço e isótopos de carbono e oxigênio) e granulométrica das tufas micríticas presentes na Mineração Calcário Xaraés, onde foi realizado um furo de trado para coleta de amostras, coletas superficiais e coleta de bloco decimétrico orientado para estudo tafonômico, além de outros depósitos com ocorrências similares na região da Serra da Bodoquena - MS para realização de comparações.

Depósitos quaternários de carbonatos continentais no Pantanal e Corumbá também foram visitados para possíveis correlações. O estudo também tem como finalidade verificar a 
potencialidade dos métodos empregados para estudos paleoambientais, como demonstrado por Meyrick \& Preece (2001), Davies \& Griffiths (2005), Andrews (2006) e Meyrich \& Karrow (2007).

A descrição destes depósitos pode fornecer informações sobre o paleoambiente local em que estes organismos viveram, ajudando a descrever a evolução dos paleoambientes da região durante parte do Quaternário, documentando-se a evolução dos processos de deposição dos micritos da região, desde uma fase pré-micrito até o último processo de sedimentação, atingindo a situação atual. 


\section{AS TUFAS CALCÁRIAS}

2.1. Aspectos geológicos da área de estudo

O Planalto da Bodoquena, descrita por Almeida (1965) como Serra da Bodoquena, está a sudeste da Planície do Pantanal entre $19^{\circ} 15^{\prime}$ e $22^{\circ} 15^{\prime}$ de latitude sul e entre $57^{\circ} 30$ e $56^{\circ} 15^{\prime}$ de longitude oeste, possui cerca de $200 \mathrm{~km}$ na direção norte-sul e até $800 \mathrm{~m}$ de altitude (Almeida, 1965; Sallun-Filho et. al., 2004).

Os depósitos carbonáticos quaternários da Serra da Bodoquena desenvolvem-se sobre as rochas calcárias do Grupo Corumbá, na Faixa de dobramentos Paraguai, da mesma forma que os Calcários Xaraiés (Figura 01) (Almeida, 1965; Araújo et al., 1982). Em casos raros assentam-se sobre outras rochas precambrianas.

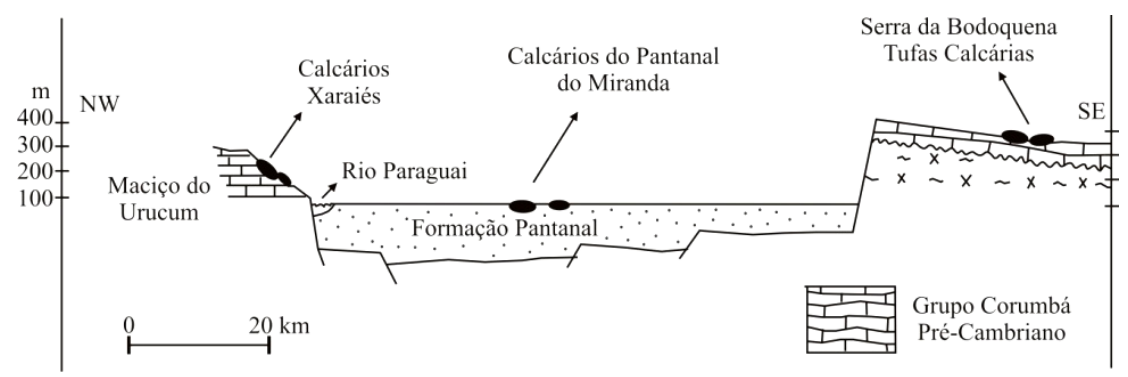

Figura 01 - Distribuição dos carbonatos quaternários sobre a Faixa de dobramentos Paraguai, segundo a classificação de Boggiani \& Coimbra (1995). Modificado de Boggiani \& Coimbra, 1995.

A Faixa de dobramentos Paraguai estende-se ao longo dos estados do Mato Grosso do Sul e Mato Grosso, por cerca de $2.000 \mathrm{~km}$. É curvilínea, convexa para noroeste, passando pela Serra da Bodoquena, Corumbá e Serra do Amolar no Mato Grosso do Sul, flexionando-se para N-NE na Serra das Araras no Mato Grosso (Figura 02) (Boggiani et. al., 1993).

Afloram na Serra da Bodoquena calcários do Grupo Corumbá, de idade ediacarana, que se assentam sobre as rochas paleoproterozóicas, do Complexo metamórfico Rio Apa. A leste do Grupo Corumbá, são encontradas rochas metassedimentares neoproterozóicas do Grupo Cuiabá (Anexo D) (Boggiani \& Alvarenga, 2004; Sallun-Filho, 2005). 
A sudeste da Serra da Bodoquena a Faixa Paraguai encontra-se encoberta por rochas da Bacia do Paraná, rochas sedimentares paleozóicas e mesozóicas, principalmente arenitos da Formação Aquidauana. Ao norte, a Serra é coberta por sedimentos quaternários da Bacia do Pantanal (Boggiani \& Alvarenga, 2004; Sallun-Filho, 2005).

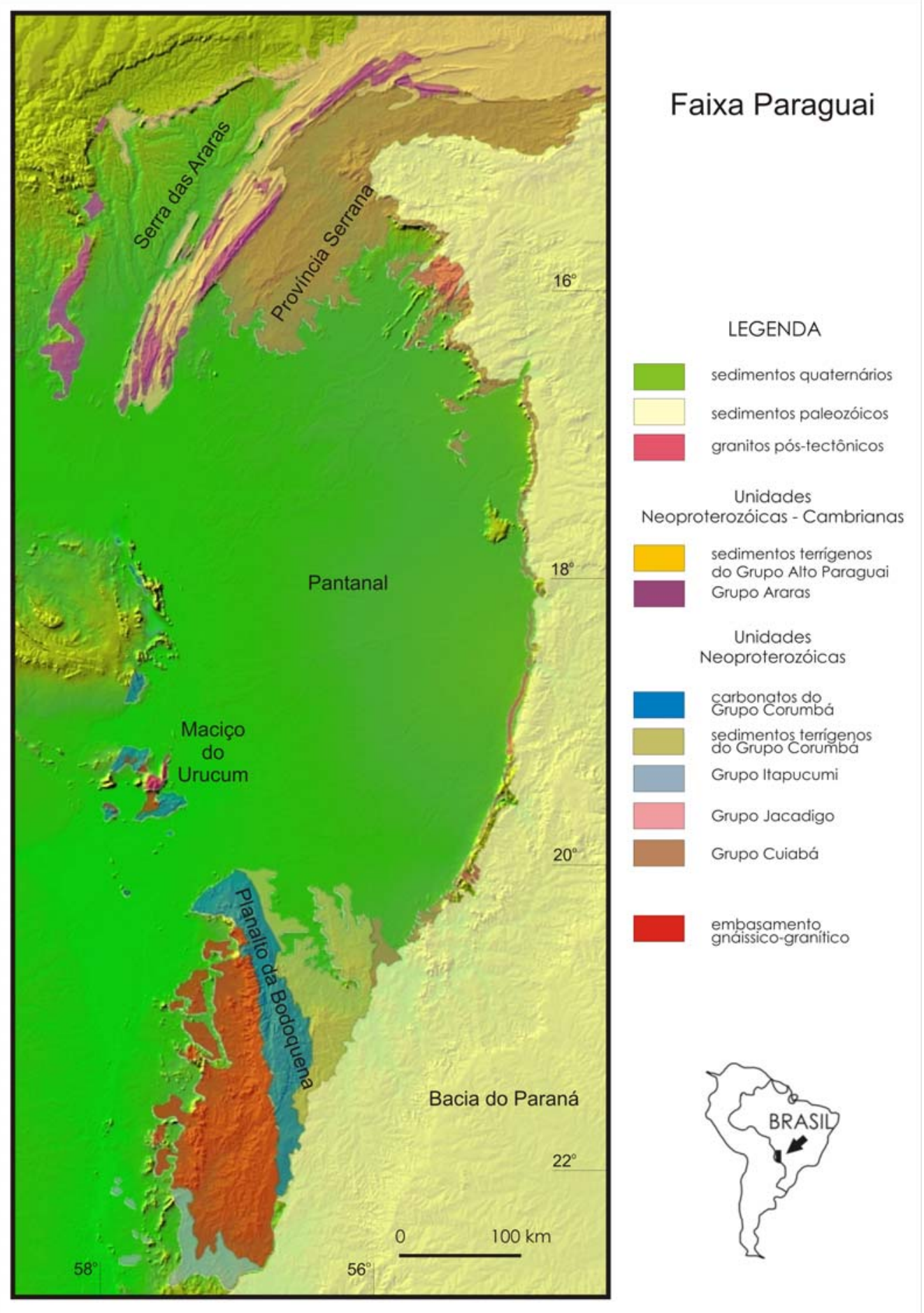

Figura 02 - Esquema geológico da Faixa Paraguai. Extraído de Oliveira, 2009. 


\subsection{Definição de tufas calcárias}

Segundo Pedley (1990) o termo tufa calcária designa rochas porosas, formadas em água doce rica em carbonatos, apresentando crescimento de micro e macrófitas, geralmente englobando restos de folhas e madeira.

O termo Kalktuff é utilizado na literatura alemã (Pedley, 1990). Já o termo Tufa é utilizado na literatura inglesa, e por vezes utilizado como sinônimo de tufa calcária na literatura brasileira, assim como cita o glossário geológico do IBGE (Araújo et al., 1999).

$\mathrm{Na}$ literatura italiana encontra-se o termo travertino, inicialmente utilizado para descrever as tufas calcárias, pois são fisicamente semelhante, entretanto, hoje é restrito aos depósitos formados a partir de precipitações em águas termais (Pedley, 1990).

De acordo com Suguio (1998) o termo em português é tufo calcário, no entanto, nomenclatura muito semelhante a tufos vulcânicos, rocha formada de material vulcânico, constituído principalmente de cinzas, podendo conter lapilli, bombas e outros fragmentos piroclásticos (Suguio, op. cit.).

Neste trabalho será utilizado o termo tufa calcária, pois muitos trabalhos nacionais já trazem este termo, além de unificar o nome junto com os trabalhos internacionais e evitar confusão com o termo tufo vulcânico.

Dois tipos de tufas foram descritas por Pedley (1990), autóctones e clásticas. As tufas autóctones envolvem tufas fitohermais e tufas estromatolíticas. As tufas clásticas podem ser fitoclásticas, oncoidais ou intraclásticas. As tufas intraclásticas envolvem tufas detríticas, microdetríticas, peloidais e paleosolos tufáceos.

As tufas autóctones fitohermais são estruturas verticais suportadas por hidrófitas e macrófitas aquáticas. São colonizadas por microfilmes de cianobactérias, bactérias cocóides, fungos e diatomáceas, cimentados por finas camadas de calcita com baixo teor de $\mathrm{Mg}$. Geralmente são encontrados anelídeos, ostracodes, larvas de insetos e moluscos. Em geral a estrutura de carbonato é rapidamente dissolvida, tornando a tufa altamente porosa e permeável. As tufas autóctones estromatolíticas, são formadas por camadas superficiais de esqueletos estromatolíticos, frequentemente associadas a cianobactérias do gênero Oscillatoria (Pedley, op. cit.). 
As tufas fitoclásticas consistem em fragmentos de vegetação incrustados, principalmente composto por folhas e galhos transportados, formando um depósito suportado por clastos (Pedley, 1990).

As tufas clásticas oncoidais possuem forma esférica, geralmente formadas em rios, ou forma mais alongada, típicas de ambientes de baixa energia, e ainda formas irregulares podem se desenvolver em ambientes estáticos. Estas estruturas oncoidais possuem núcleos formados de fragmentos de madeira, gastrópodes ou grãos, formando uma tufa suportada por grãos associada a tufa intraclástica ou micritos (Pedley, op. cit.).

O tipo de tufa intraclástica detrítica é formado por fragmentos de tufa fitohermal e de cimentos pré-formados, em geral pela fração silte e argila. Estes fragmentos são transportados durante períodos de maior volume de água e depositados nos canais fluviais, ou áreas alagáveis (Pedley, 1990).

As tufas microdetríticas, ou micríticas, são os sedimentos mais finos encontrados entre as tufas. É encontrado em depósitos de lagos, lagoas e alagados. Pode formar finas camadas, mas frequentemente não apresenta estruturas deposicionais. A origem destes depósitos ainda não é clara, segundo Pedley (op. cit.) alguns autores sugerem sua formação por influência da fotossíntese, que libera $\mathrm{O}_{2}$, induzindo a precipitação do carbonato no ambiente. Geralmente estão associados a gastrópodes terrestres e de água doce, carófitas e ostracodes.

Também caracterizada como tufa microdetrítica, as tufas peloidais somente são identificadas petrograficamente. São pelóides agrupados em massas polinucleadas de 10 a 70 $\mu \mathrm{m}$ de diâmetro. Podem ser suportadas pelos grãos, mas são mais comuns as compactas (Pedley, 1990).

As tufas calcárias micríticas quaternárias apresentam-se nas formas de tufas porosas inconsolidadas ou tufas porosas não friáveis. Com dissoluções e reprecipitações pelo intemperismo, perdem os poros tornando-se compactas (Guerra, 1993). Podem ser sedimentadas quimicamente a partir de águas de fontes, lagos ou água subterrânea percolante (Suguio, 1998), mas não se descarta a hipótese da atuação da bioindução em conjunto.

Em geral, nos depósitos fósseis de tufas calcárias, no horizonte inferior, há tufas degradadas, formando rochas mais compactas. No horizonte superior há sedimento rico em matéria orgânica, que pode conter gastrópodes pulmonados, formando paleosolos de tufas (Pedley, 1990). 
2.3. A Formação Xaraiés e os calcários quaternários da região

A Formação Xaraiés tem como embasamento rochas do Grupo Corumbá e conglomerados arcosianos da base do Grupo Jacadigo na zona limítrofe com a Bolívia (Almeida, 1945) (Figura 02).

Em geral é um depósito calcário, irregular, de incrustação, estando ausente qualquer estrutura sedimentar. Possui cor creme, rosada ou raramente avermelhada, sendo consistente e de porosidade variável (Almeida, 1945).

Almeida (1945) distinguiu quatro tipos de rochas:

a) tufa calcária com vegetais fósseis, apresentando orifícios tubulares grossamente paralelos e impressões foliares, matriz maciça, com algum material detrítico, principalmente quartzo, de estrutura cristalina e granulação variável.

b) tufa calcária leve e muito esponjosa, de estratificação grossa, com lâminas contorcidas, de cor creme acinzentada, com muitos orifícios de galhos e impressões das duas faces das folhas grossamente acamadas em cimento friável.

c) conglomerado grosso com cimento calcário, apresentando fragmentos arredondados ou angulosos, predominantemente de calcário negro. De matriz maciça, cor creme clara, avermelhada ou acinzentada. São raros fósseis, sendo eventualmente encontrados fragmentos de gastrópodes.

d) travertino com gastrópodes, de pouca porosidade, tenaz, de cor creme acinzentada, avermelhada localmente. Sem estratificação macro ou microscópica, com grãos milimétricos ou sub-milimétricos de quartzo sub-arredondado, e calcário negro, com gastrópodes encontrados dispostos confusamente em geral fragmentados. Depósito impropriamente chamado de travertino, adequando-se a denominação de micrito.

Inclui-se aos carbonatos da Formação Xaraiés, as tufas calcárias da Serra da Bodoquena e tufas calcárias na Serra das Araras (Figura 02) (Correia \& Auler, 2006; Correia \& Auler, 2007).

Após a classificação de Almeida para os carbonatos da Formação Xaraiés, Boggiani \& Coimbra (1995) separaram os calcários da região matogrossense de acordo com suas origens, sendo: Calcário Xaraiés, Lentes calcárias do Pantanal do Miranda e Tufas Calcárias da Serra da Bodoquena (Figura 01). 
Os Calcários Xaraiés seriam os calcretes da Formação Xaraiés descritos por Almeida (1965) na escadaria que corta a escarpa da cidade de Corumbá, com acesso ao porto, conhecida na cidade como "Escadinha da XV" (Figura 03), como conglomerado grosso. Segundo Boggiani \& Coimbra (op. cit.) devem ser tratados separadamente das tufas, por estas ainda estarem em processo de formação, ao contrário desses carbonatos, interpretados como calcretes, relacionados a clima mais seco do que o atual. Roque (1999) e Ribeiro et al. (2001) verificaram o equilíbrio radioativo entre o ${ }^{246} \mathrm{U}$ e o ${ }^{226} \mathrm{Ra}$, admitindo idade pleistocênica para os calcretes de Corumbá descritos por Almeida (1945).

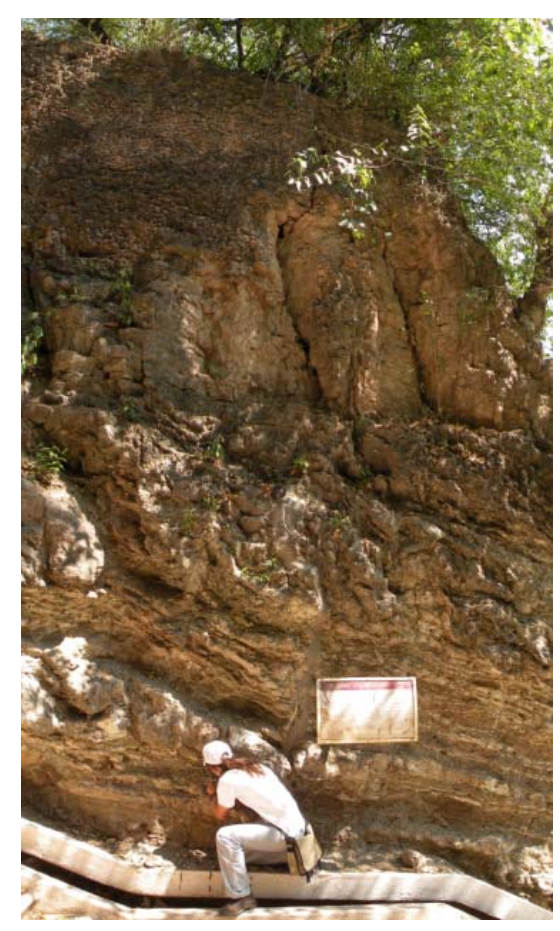

Figura 03 - Seção tipo da Formação Xaraiés na Escadinha da XV, Corumbá, MS.

Os calcários do Pantanal do Miranda seriam formados da precipitação do carbonato em ambiente lacustre, nas planícies alagadas dos rios Aquidauana, Abobral e Miranda (Figura 04 A) (Boggiani \& Coimbra, 1995). Ribeiro et al. (2001) obtiveram idade de $3.910 \pm 110$ anos A.P. para estes carbonatos pelo método ${ }^{14} \mathrm{C}$.

É provável que a reativação de falhas do lineamento Transbrasiliano tenha causado o rebaixamento do Pantanal durante o Pleistoceno Inferior (Gesicki \& Riccomini, 1998; Soares et. al., 1998; Riccomini \& Assumpção, 1999). É uma bacia sedimentar tectonicamente ativa, entretanto, ainda há pouco conhecimento sobre a tectônica, a cronoestratigrafia e a evolução paleogeográfica e processos sedimentares da Bacia do Pantanal para maiores conclusões (Assine, 2003). 

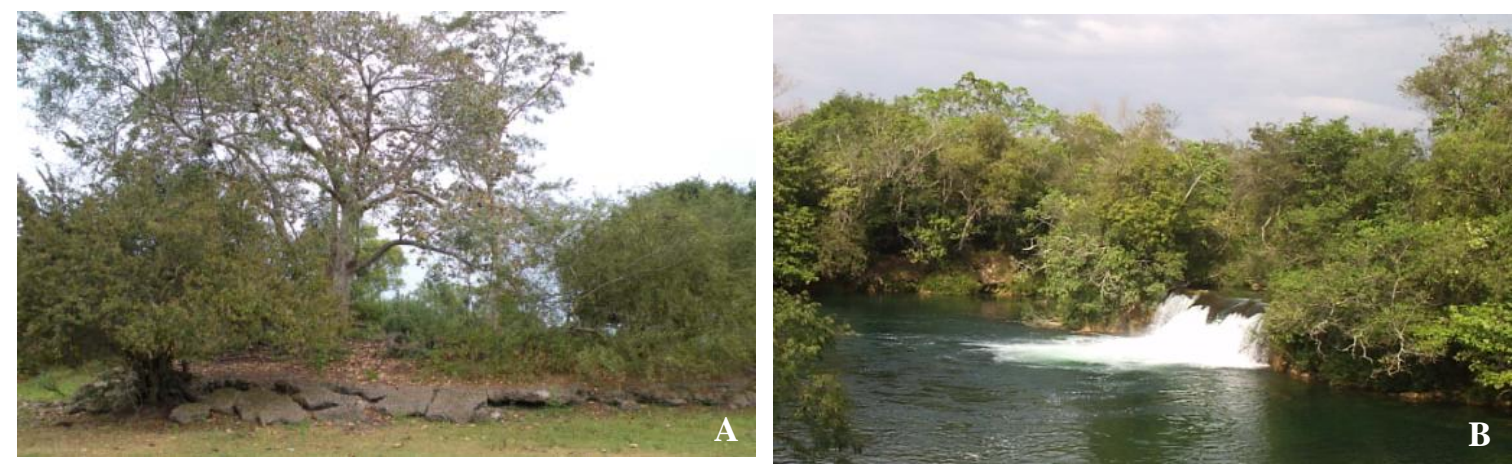

Figura 04 - Calcários da região matogrossense segundo Boggiani \& Coimbra (1995). A) Calcários do Pantanal do Miranda, Estrada Parque Pantanal Sul, MS. B) Tufa de cachoeira no Rio Formoso, Bonito, MS.

Já as Tufas da Serra da Bodoquena, envolvem: tufas na forma de cachoeiras e represas, formadas em quedas de água pela precipitação do carbonato pela degaseificação do gás carbônico e por influência de diatomáceas, e cianobactérias e musgos (Figura 04 B). Datações pelo método ${ }^{14} \mathrm{C}$ revelaram idades entre 2130 a 3410 anos A.P. para estes tipos de carbonatos (Ribeiro et al., 2001); e os micritos inconsolidados (Figura 05) devem ter sido formados por precipitação do carbonato provavelmente por bio-indução do fitoplâncton que consome $\mathrm{CO}_{2}$ (Boggiani \& Coimbra, 1995; Boggiani et al., 2002). Estes micritos sempre contêm gastrópodes, com idade de cerca de 5.200 A.P., obtida pelo método ${ }^{14} \mathrm{C}$ (Turq et al., 1987).

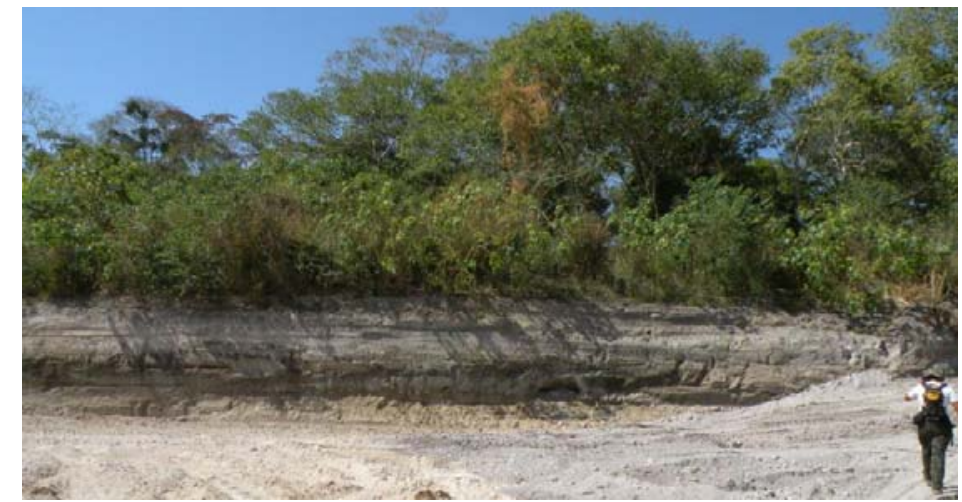

Figura 05 - Depósito de micritos inconsolidados. Mineração Calcário Xaraés, Bonito, MS.

Segundo Boggiani et al. (2002) estes depósitos seriam formados em meandros abandonados e o acúmulo de micrito reduziria a profundidade das lagoas associadas, formando brejos ao final da deposição, com camadas orgânicas superficiais, o que promove percolação de águas aciduladas, impedindo a consolidação da lama calcária, tornando friáveis as conchas de moluscos. 
Os micritos inconsolidados foram chamados de tufas inconsolidadas por Roque (1999) e Ribeiro et al. (2001), interpretados também como depósitos de lago. Os autores explicam sua origem a partir de lagos ricos em $\mathrm{CaCO}_{3}$, com a precipitação e deposição como sedimentos de fundo, depositando-se as partículas finas de carbonato em suspensão, por ação da gravidade.

Os micritos inconsolidados, ou calcários pulvurulentos, também ocorrem em meandros abandonados do Rio Formoso, como depósitos isolados, cada um com cerca de $300.000 \mathrm{~m}^{3}$ de volume (Boggiani et al., 2002; Sallun Filho et al., 2004).

Na região da Serra da Bodoquena, Cristalli (2006) notou a falta de deposição de tufas atuais no leito do Rio Sucuri, provavelmente causada pela baixa correnteza de água, tornando difícil a liberação do gás carbônico. Este rio possui água muito transparente e abundante vegetação subaquática e submersa, e vegetação terrestre afastada do leito do rio. Já as águas do Rio Formoso contendo tufas, não são tão transparentes, devido ao escape de gás carbônico e precipitação do carbonato de cálcio, com vegetação terrestre mais fechada e próxima ao leito do Rio. Nas porções mais calmas do fluxo de água, a deposição das tufas ocorre nas margens. Em quedas de água, o carbonato é depositado nas próprias quedas formando cachoeiras com crescimento a jusante.

Áreas alagadas próximas aos rios também ocorrem na região com densa vegetação rasteira próxima as margens e grande quantidade de macrófitas na água, principalmente algas caráceas (Figura 06) e deposição de carbonatos no fundo (Boggiani, com. pessoal).

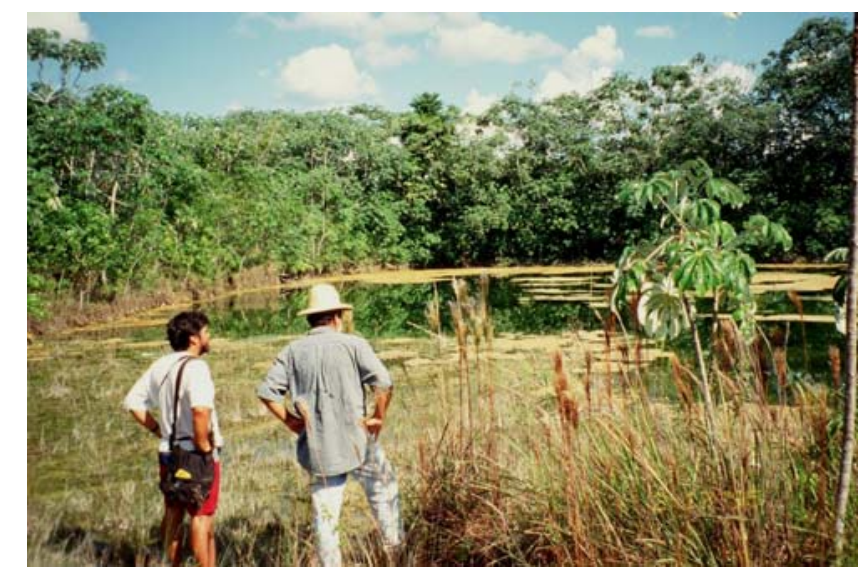

Figura 06 - Área alagada próxima às margens do Rio Formoso, remansos com grande crescimento de algas caráceas. Foto: Laboratório de Sedimentologia Professor Armando Coimbra, janeiro de 1995, a partir da esquerda Professor Paulo. C. Boggiani e Professor Armando M. Coimbra. 
2.4. Fósseis presentes nas tufas calcárias de Mato Grosso do Sul

Os estudos de ostracodes e gastrópodes holocênicos terrestres e de água doce ainda são escassos e pouco pormenorizados no Brasil, ao contrário de outros depósitos do mundo.

A presença de gastrópodes quaternários em Mato Grosso do Sul foi citada na região de Corumbá por Almeida (1945), com identificação de Mendes como Stenogyra (Opeas) misera Orb., Zonitoides sp. e Bulimulus sp. em calcários da Formação Xaraiés (In. Almeida, 1945). Porém, não foram estudadas sob ponto de vista dos jazimentos e outras possíveis informações ambientais. Outros autores (Turq et al., 1987; Roque, 1999; Ribeiro et al., 2001) apenas utilizaram os fósseis para obter datações, sem fornecer sua identificação.

Espécimes quaternários em micritos inconsolidados da Serra da Bodoquena foram citados e identificados como Biomphalaria, Physa e Aquidauania (Boggiani et al., 2002). Boggiani et al. (1998) encontraram espécies da família Ampullariidae e o gênero Biomphalaria nas Lentes Calcárias no Pantanal do Miranda.

No depósito micrítico da Mineração Calcário Xaraés (Bonito-MS) Scheffler (2006) identificou alguns gêneros de gastrópodes, Pomacea, Bulimulus, Biomphalaria, Drymaeus e Megalobulimulus (Figura 07). Utida et al. (2007) também identificaram o gênero Biomphalaria, além das espécies Pomacea canaliculata (Lamarck, 1804), Pomacea semperi (Kobelt, 1914), Idiopyrgus souleyetianus Pilsbry, 1991 (Aquidauania brasiliensis Rey, 1954) e Bulimulus angustus Weyrauch, 1966 na Mineração Calcário Xaraés (Figura 07).
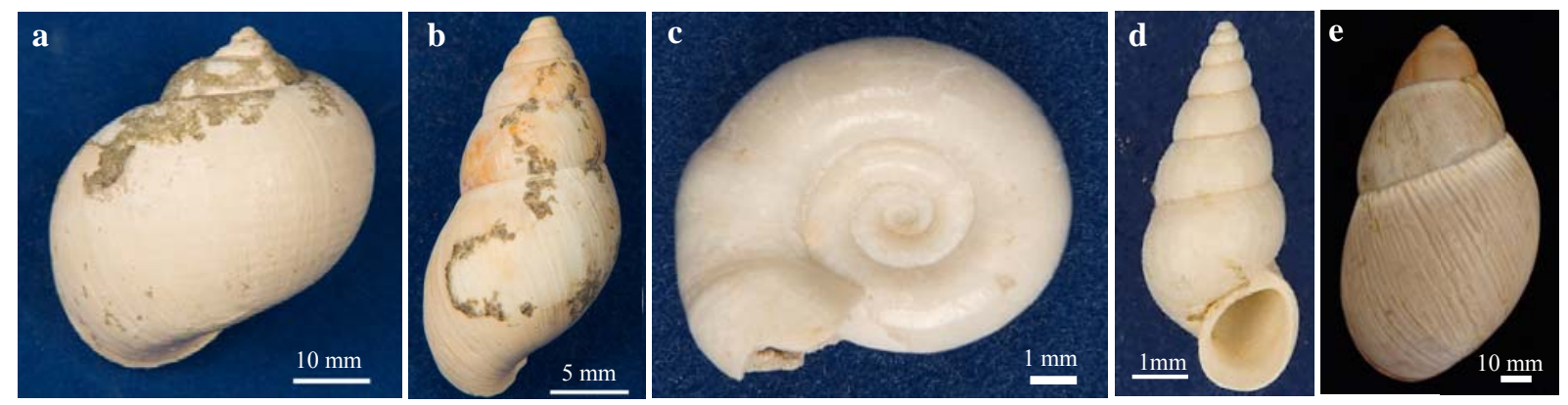

Figura 07 - Gêneros e espécies de gastrópodes encontrados nos depósitos calcários quaternários da Serra da Bodoquena. a) Pomacea canaliculata. b) Bulimulus aungustus. c) Biomphalaria. d) Idiopyrgus souleyetianus. e) Megalobulimulus.

Utida et al. (2008) também encontraram ostracodes, girogonites de algas caráceas, micro e macrogastrópodes nestes depósitos, sugerindo deposição em lagos. 
Estes carbonatos foram classificados como Formação Xaraiés, descrita por Almeida (1945) inicialmente na escarpa de Corumbá (MS), entre Porto Aurora e Ladário. Supôs-se, então, que estes calcários teriam sido formados pedogenéticamente em cones de dejeção de torrentes, sugerindo sua deposição como calcretes ${ }^{1}$ em clima semi-árido, provavelmente durante o Pleistoceno (Almeida, 1945; Assine, 2003), diferentemente dos depósitos micríticos possivelmente lacustres da região de Bonito, MS.

${ }^{1}$ Calcrete - Acumulação terrestre, predominantemente de carbonato de cálcio, resultado da cimentação por precipitação a partir de águas vadosas ou freáticas saturadas de carbonato de cálcio (Wright \& Tucker, 1991). Ocorre em climas áridos e se acumula localmente em camadas, permeando e cimentando fragmentos residuais e solos dessas regiões (Suguio, 1998). 


\section{MATERIAIS E MÉTODOS DE ESTUDO}

Três estudos de campo foram realizados, o primeiro entre 20 e 25 de julho de 2007, o segundo entre 25 e 31 de agosto de 2008 e o terceiro entre 21 e 27 de março de 2009. Durante o primeiro estudo de campo foram obtidas amostras dos micritos inconsolidados da Mineração Calcário Xaraés, Bonito, MS, através de coleta em porção exposta, complementada por amostragem por furo de trado, compondo um perfil, e mais 5 depósitos de micritos foram selecionados para as análises laboratoriais. Os demais depósitos foram apenas descritos durante trabalhos de campo.

Análises físicas e químicas foram realizadas para caracterização dos depósitos. Análise granulométrica, teor de carbonato, identificação de argilominerais por difratometria de raio-x, análise composicional por fluorescência de raio-x e análise de isótopos estáveis de carbono e oxigênio compõem as descrições físicas e químicas.

As análises paleontológicas foram compostas por coleta e identificação de macrofósseis e microfósseis, nas amostras obtidas da porção exposta e coleta por furo de trado da Mineração e dos demais depósitos, análise tafonômica de amostra orientada da Mineração Calcário Xaraés, análise ecológica dos dados de microfósseis e dos macrofósseis obtidos da análise tafonômica, além da análise biométrica destes macrofósseis.

\subsection{Locais de estudo}

A área de estudo localiza-se na região da Serra da Bodoquena e seus arredores no Estado do Mato Grosso do Sul, Brasil, principalmente próxima à cidade de Bonito (Figura 09).

O principal depósito de estudo, a Mineração Calcário Xaraés, ponto 1, onde foi realizado furo de trado e coleta em porção exposta, localiza-se a $18 \mathrm{~km}$ do centro do município de Bonito, MS, na Fazendo São Geraldo. É um afloramento exposto de cerca de 600x600m (Figura 08 e 09), onde é lavrado o carbonato para uso como corretivo de solo. Devido à alta friabilidade, é apenas desagregado e seco antes da utilização. 


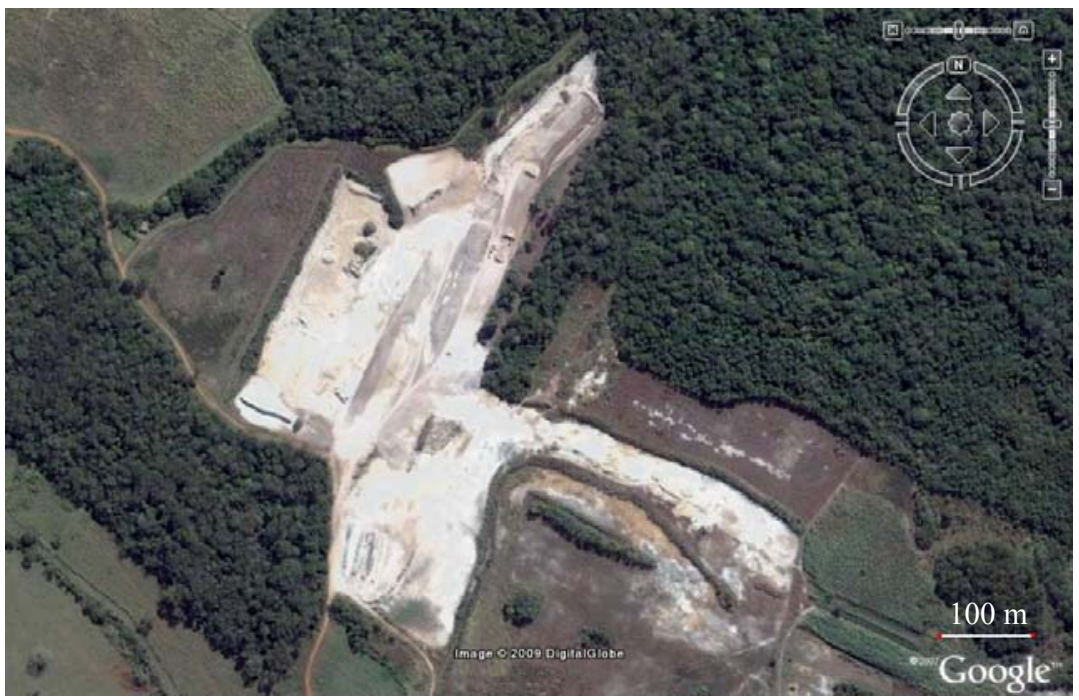

Figura 08 - Vista aérea do depósito de micritos da Mineração Calcário Xaraés. Fonte: Google, 2009.
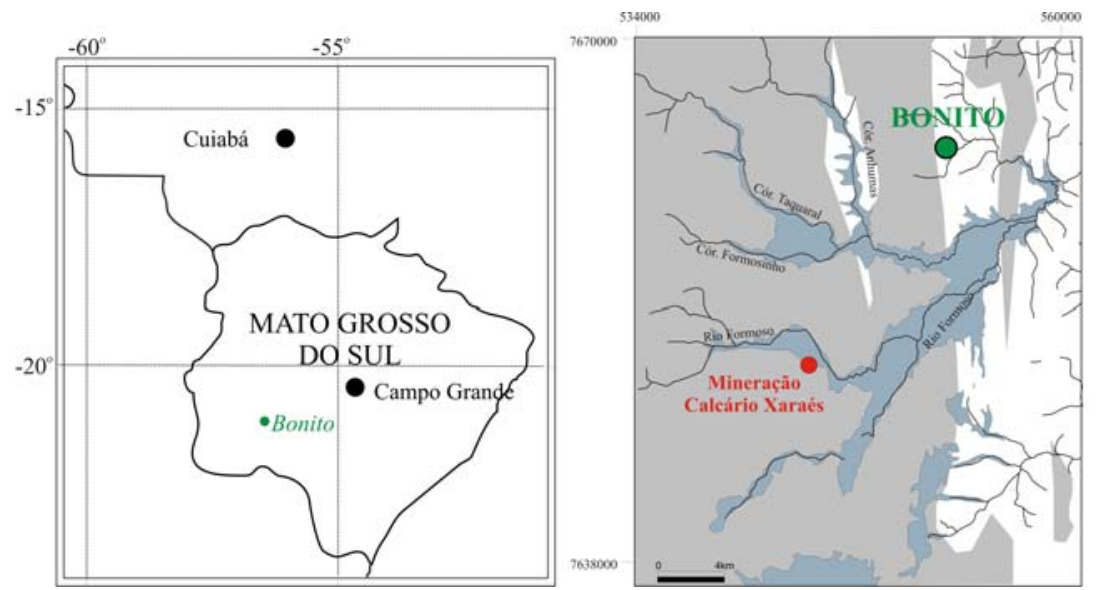

Tufas

Rochas carbonáticas do Grupo Corumbá

Áreas não carbonáticas

Figura 09 - A) Localização do município de Bonito no Estado do Mato Grosso do Sul. B) Localização da Mineração Calcário Xaraés (Geologia modificada de Araújo et al., 1982).

Além do depósito da Mineração, foram visitados outros 22 pontos, entre eles depósitos de micritos fósseis e outras tufas atuais (Tabela 01), dos quais 5 depósitos micríticos, mais a Mineração, foram estudados em laboratório. O Anexo D mostra os pontos estudados sobre um mapa geológico modificado de Sallun-Filho (2005). Os depósitos de tufas dos pontos estudados, geralmente associados com as drenagens dos rios atuais, vão além das áreas quaternárias amostradas no mapa.

Três pontos foram amostrados fora do contexto da Serra da Bodoquena, os Calcários do Pantanal do Miranda, na região do Pantanal Sul (pontos 32 e 38), descritos por Boggiani \& Coimbra (1995), e um afloramento descrito por Almeida (1965) como conglomerados com cimento calcário, no porto de Corumbá, MS (ponto 34), agrupados por Boggiani \& Coimbra 
(1995) como Calcários Xaraés (Tabela 01). Estes pontos foram amostrados com a finalidade de realizar possíveis comparações com os micritos da Serra da Bodoquena.

Tabela 01 - Projeções UTM dos pontos estudados no Estado do Mato Grosso do Sul, os pontos estudados em destaque.

\begin{tabular}{rrrl}
\hline \multicolumn{5}{c}{ Projeções dos pontos estudados em Mato Grosso do Sul } \\
\hline Pontos & UTM WGS84 zona 21k & \multicolumn{1}{c}{ Local } \\
\hline $\mathbf{1}$ & 544652 & 7650534 & Mineração Calcário Xaraés - Bonito \\
$3 . \mathbf{4}$ & 545726 & 7649713 & Rio Formoso - Bonito \\
5 & $\mathbf{5 5 1 8 1 3}$ & $\mathbf{7 6 7 7 3 6 9}$ & Cachoeiras do Mimoso - Bonito \\
$\mathbf{6}$ & 551762 & 7677565 & Cachoeiras do Mimoso - Bonito \\
$\mathbf{7}$ & $\mathbf{5 5 1 8 4 6}$ & $\mathbf{7 6 7 7 3 9 2}$ & Cachoeiras do Mimoso - Bonito \\
11 & 539492 & $\mathbf{7 6 7 0 7 2 7}$ & Rio Seputa - Bonito \\
12 & 536885 & 7675291 & Estrada para Fazenda Baía das Garças \\
13 & 536396 & 7721952 & Rio Betione - Balneário Cabeceira do Betione - Bodoquena \\
$\mathbf{1 4}$ & $\mathbf{5 2 9 4 6 6}$ & $\mathbf{7 7 2 8 0 5 4}$ & Rio Campina - Bodoquena \\
15 & 536210 & 7718678 & Balneário Municipal Prudente Corrêa - Bodoquena \\
$\mathbf{1 6}$ & $\mathbf{5 5 2 2 4 7}$ & $\mathbf{7 6 6 5 2 6 2}$ & Antiga Mineração de carbonatos - Bonito \\
17 & 564035 & 7665028 & Rio Formoso - Camping Poliana - Bonito \\
18 & 563837 & 7664270 & Rio Formoso - Ilha do Padre - Bonito \\
19 & 550.753 & 7.656 .577 & Rio Formozinho - Bonito \\
21 & 548.189 & 7.649 .912 & Rio Formoso - Praia da Figueira - Bonito \\
23 & 547.963 & 7.630 .237 & Rio do Prata - Bonito \\
28 & 547.129 & 7.680 .909 & Rio Mimoso - Estrada Bonito-Bodoquena \\
29 & 543.312 & 7.686 .949 & Córrego Olaria - Estrada Bonito-Bodoquena \\
30 & 540.355 & 7.692 .517 & Córrego Pitangueiras - Estrada Bonito-Bodoquena \\
--- & 545.764 & 7.648 .368 & Nascente do Rio Sucuri \\
32 & 496.138 & 7.834 .854 & Lentes do Pantanal do Miranda - Estrada Parque Pantanal Sul \\
34 & 431.445 & 7.899 .576 & Margens do Rio Paraguai - Corumbá \\
38 & 495.429 & 7.847 .272 & Lentes do Pantanal do Miranda - Estrada Parque Pantanal Sul - Hotel Faz. Xaraés \\
\hline
\end{tabular}

\subsection{Análise granulométrica e teor de carbonato}

A análise granulométrica e do teor de carbonato foram realizadas no laboratório de sedimentologia "Professor Armando Márcio Coimbra" do Instituto de Geociências da Universidade de São Paulo. Tais procedimentos foram realizados de acordo com os padrões estabelecidos por Giannini et al. (2004).

Para a análise granulométrica foi utilizada cerca $60 \mathrm{~g}$ de sedimento úmido, e após sua secagem em estufa a $60^{\circ} \mathrm{C}$. O sedimento foi desagregado e mantido em proveta de $1000 \mathrm{ml}$ com água destilada e cerca de $1 \mathrm{~g}$ de $\mathrm{Na}_{2} \mathrm{P}_{2} \mathrm{O}_{7}$ para evitar a floculação das argilas. Depois de, descansar por 2 horas para que os grãos mais grossos sedimentassem por ação da gravidade, foi então submetido à pipetagem para quantificação das frações argila e silte.

Após lavagem das amostras por elutriação, para eliminação do $\mathrm{Na}_{2} \mathrm{P}_{2} \mathrm{O}_{7}$ utilizado e da argila e silte, as amostras foram secas e peneiradas em vibrador mecânico com peneiras com 
intervalos de 0,5 phi e pesadas. Para análise estatística da análise granulométrica foi utilizada planilha desenvolvida por Gianinni et al. (2007).

A análise do teor de carbonato foi feita em $5 \mathrm{~g}$ de amostra, seca e pesada, com adição de $\mathrm{HCl} 10 \%$, após o término da reação foi adicionada água destilada e filtrada a mistura em filtros de $3 \mu \mathrm{m}$ de porosidade. O teor de carbonato foi calculado através da diferença de peso antes e após o ataque químico.

3.3. Identificação dos argilominerais e análise química e de elementos traços

As identificações das argilas encontradas nas amostras foram realizadas no Laboratório de Difração de Raios X do Instituto de Geociências da Universidade de São Paulo, equipado com difratômetro de pó Siemens modelo D5000, geradores de Raios X e câmeras de difração de vários tipos para pó ou monocristais (Debye-Scherer e Guinier, Gandolfi, câmera de precessão), a partir de amostras coletadas durante o processamento para análise granulométrica. As lâminas foram preparadas por evaporação natural da amostras ou por centrifugação a $5000 \mathrm{rpm}$, utilizando o precipitado para produzir uma fina camada sobre a lâmina.

A análise composicional das amostras foi realizada no Laboratório de Fluorescência de Raios X do Departamento de Mineralogia e Geotectônica do Instituto de Geociências da Universidade de São Paulo, com equipamento automático Philips, modelo PW2400, com método desenvolvido por MORI et al. (1999).

\subsection{Análises de isótopos estáveis de carbono e oxigênio}

As análises isotópicas de $\delta^{13} \mathrm{C}_{\mathrm{V}-\mathrm{PDB}}$ e de $\delta^{18} \mathrm{O}_{\mathrm{V}-\mathrm{PDB}}$ foram feitas no Centro de Pesquisas Geocronológicas - CPGeo do Instituto de Geociências da Universidade de São Paulo, no Laboratório Isótopos Estáveis - LIE.

$\mathrm{O}$ método utilizado é o da determinação da razão ${ }^{13} \mathrm{C} /{ }^{12} \mathrm{C}$ e da razão ${ }^{18} \mathrm{O} /{ }^{16} \mathrm{O} \mathrm{em}$ carbonatos através do método de MacCrea (1950) e Urey et al. (1951). O CO² é extraído pela reação com ácido fosfórico a $100 \%\left(\mathrm{~d}>1.92 \mathrm{~g} / \mathrm{cm}^{3}\right)$ sob vácuo e analisado em espectrômetro de massa de fonte gasosa Deltaplus Advantage, ThermoFinnigan. 
As amostras foram preparadas com equipamentos esterilizados para evitar contaminação e enviadas maceradas ao laboratório. Nas análises dos sedimentos parte das amostras foram maceradas com todo material que a compunha. Para as análises isotópicas dos gastrópodes houve selecionamento e limpeza dos organismos com a extração mecânica dos sedimentos internos e externos e posteriormente macerados.

Foram escolhidos gastrópodes do gênero Pomacea para as análises, quando este gênero não foi encontrado ou os indivíduos tiveram massa insuficiente para a análise foram utilizados outros gêneros disponíveis.

\subsection{Coleta e identificação dos moluscos}

Os moluscos foram coletados aleatoriamente no campo, apenas para analise qualitativa, conhecimento dos espécimes e identificação daqueles que foram encontrados nas amostras devidamente coletadas. Em laboratório em $100 \mathrm{~g}$ de amostra os moluscos foram separados e identificados. Baseado em Simone (2006) e outros trabalhos realizados na região, os moluscos foram classificados por comparação morfológica. Os espécimes coletados foram depositados na Coleção Científica do Instituto de Geociências da Universidade de São Paulo (Anexo E).

\subsection{Análise micropaleontológica}

Para verificar a existência de microfósseis nos depósitos estudados foi utilizada metodologia do laboratório de Micropaleontologia "Setembrino Petri". Uma porção da amostra foi pesada em mesma quantidade, previamente seca em estufa

Foram consideradas 17,78 gramas de amostra seca, definidas pela porção utilizada na primeira amostra estudada. Vale deixar claro que o objetivo da análise micropaleontológica não é taxonômico, e sim verificar a existência de microfósseis.

À amostra foi adicionada água para auxiliar a desagregação do sedimento, foi levada em chapa quente $\left(80^{\circ} \mathrm{C}\right)$ para que os movimentos de ascensão da água ajudem na desagregação dos sedimentos. 
Em seguida a amostra foi peneirada com auxilio de água nas peneiras de abertura 0,5 0,125 - 0,063 e 0,021 mm. O material peneirado e lavado foi filtrado em papel filtro de $3 \mu \mathrm{m}$ e colocado em estufa para secar. Após secos os sedimentos são flotados em tricloroetileno, os microfósseis tendem a boiar, pois têm peso específico menor que o tricloroetileno.

O sobrenadante foi coado em papel filtro de $3 \mu \mathrm{m}$, secado e triado em placa de Petri para coleta dos microfósseis. A triagem do material foi feita sob estereomicroscópio, os microfósseis foram separados e colados com goma de alcatina (formol, álcool, água e goma) em lâminas quadriculadas e numeradas. Com as lâminas prontas foram previamente identificados os microfósseis encontrados.

Os espécimes coletados foram depositados na Coleção Científica de Micropaleontológica do laboratório "Setembrino Petri" no Instituto de Geociências da Universidade de São Paulo (Anexos F, G e H), alguns espécimes não puderam ser recuperados após MEV ou foram fragmentados durante manuseio.

A numeração seguiu o padrão utilizado na coleção e leva em anexo os detalhes das lâminas (Anexos F, G e H). A numeração inicia-se pelo código do livro (GP/5E), seguida pelo número da lâmina (GP/5E-4068), seguida pelo número do quadrante da lâmina (GP/5E4068.1) e no caso da lâmina 4068 pela ordem de alinhamento dos fósseis dentro do quadrante (GP/5E-4068.1.2).

\subsection{Identificação dos microfósseis}

Para a identificação dos ostracodes foram utilizadas imagens de Microscópio Eletrônico de Varredura, para a observação da morfologia dos indivíduos. Estas imagens foram realizadas no laboratório de Microscopia Eletrônica de Varredura do Instituto de Geociências da Universidade de São Paulo.

A classificação dos ostracodes é baseada nas características morfológicas das impressões musculares, ornamentação e outras características. Quando possível foi utilizada a chave de Grekoff (1956) e Van Morkhoven (1963), além de outros trabalhos especializados.

A identificação dos microgastrópodes também foi baseada em Simone (2006) por comparação morfológica. 
Já a identificação dos girogonites da alga caráceas encontradas foram realizadas baseadas em Feist (2005) e outros trabalhos especializados.

\subsection{Análises tafonômicas e morfológicas}

As análises tafonômicas foram realizadas em amostra coletada com orientação em relação ao Norte (Figura 10 e 11). A coleta do bloco orientado foi realizada em etapas: 1) escavação da superfície, 2: escavação da frente, 3) escavação das laterais, 4) escavação da base, 5) escavação da porção posterior, e 6) retirada e moldagem do bloco para acomodação em caixa de isopor para manter mesmas características do depósito.
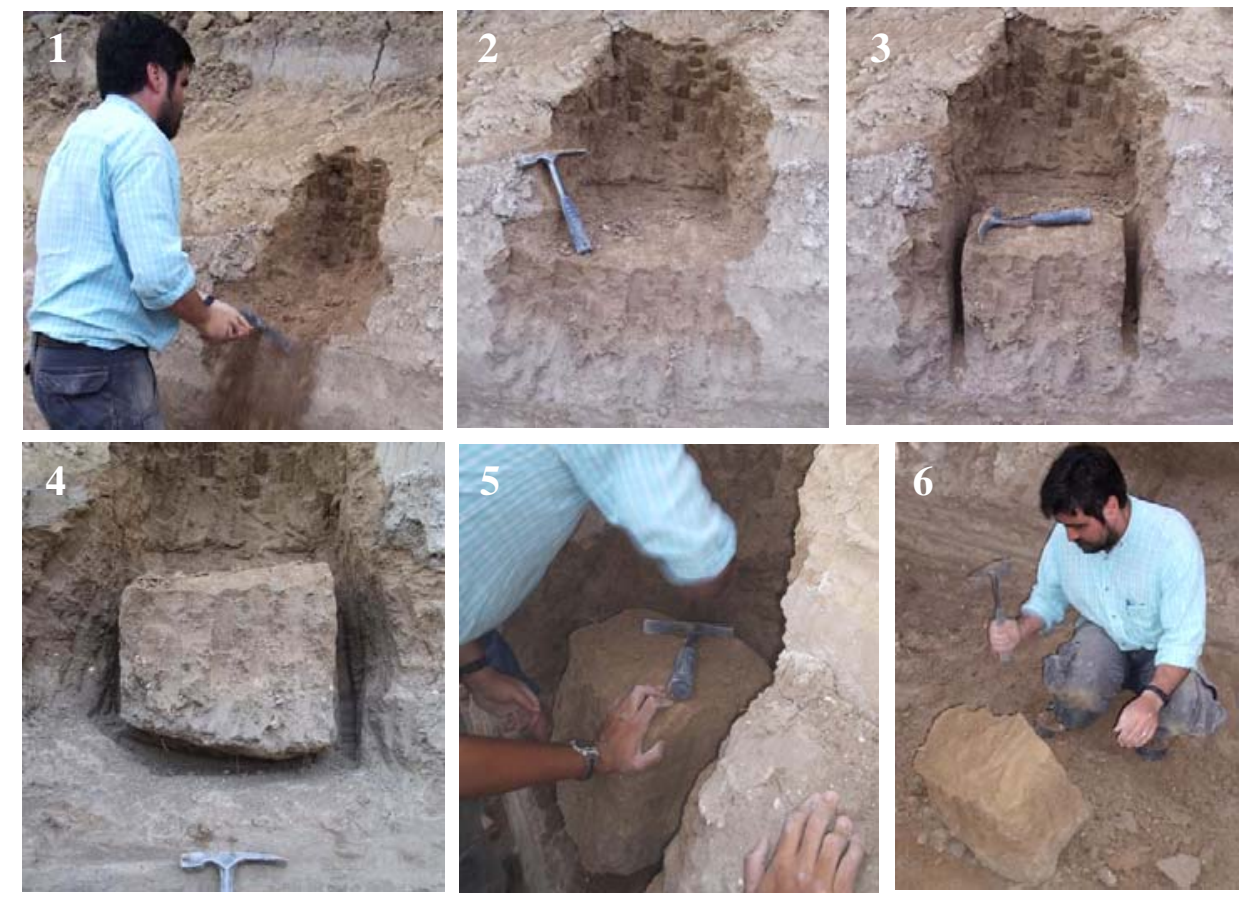

Figura 10 - Coleta do bloco orientado em micritos inconsolidados da lavra da Mineração Calcário Xaraés. Explicação no texto.

O resultado da coleta foi um bloco com lados de $32 \times 31,5 \times 15,5 \times 17 \mathrm{~cm}$ e $25,5 \mathrm{~cm}$ de altura (Figura $11 \mathrm{~d}$ ).

Atributos tafonômico e sedimentológicos foram eleitos baseados em Simões \& Ghilardi (2000), Ghilardi (2004) e Kotzian \& Simões (2006), constituindo um protocolo tafonômico (Anexo A). 
Dois tipos de análises foram realizados, uma na superfície do bloco em planta e outra no perfil da face norte, para obter dados para comparação. Para a análise em planta foram estabelecidos quadrantes de 4,5x5,5 cm para localização aproximada dos bioclastos na superfície do bloco (Figura 11 a). Da mesma forma a análise em perfil recebeu quadrantes de $4,5 \mathrm{x} 5 \mathrm{~cm}$ (Figura $11 \mathrm{~b}$ e d).

a
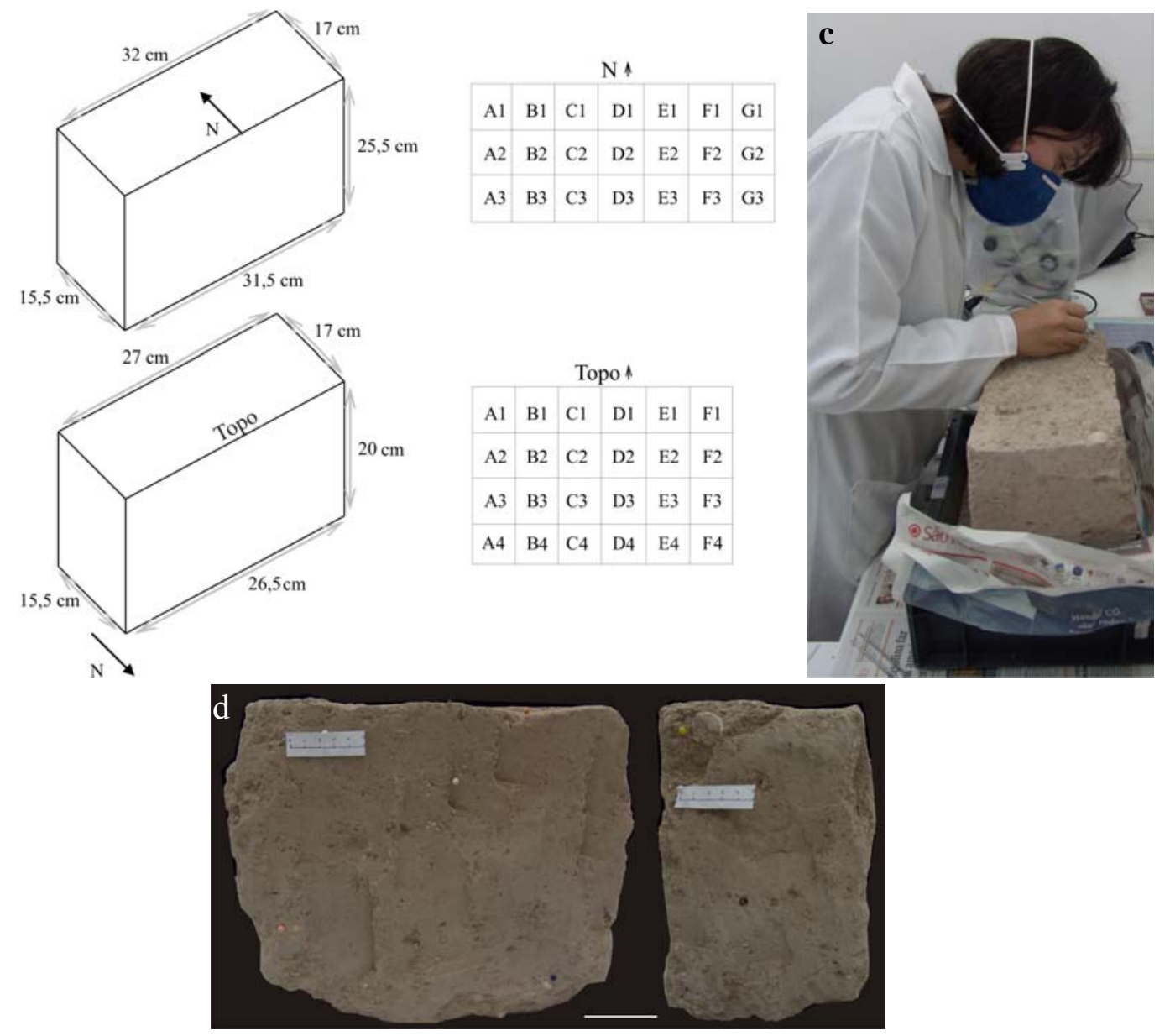

Figura 11 - Bloco analisado no estudo tafonômico. a) representação do bloco em planta. b) representação do bloco em perfil. c) Exemplo de trabalho no bloco. d) Face norte e lateral direita do bloco.

Observou-se a orientação dos organismos em graus, sendo o Norte considerado $0^{\circ}$ para a análise em planta e o topo para a análise em perfil; posição da concha, perpendicular, oblíqua ou concordante com o substrato, assim como a posição da abertura da concha; a quantidade de fragmentação, incrustação e bioerosão, corrosão ou abrasão em porcentagem estimada e localização da assinatura; textura e coloração alteradas, e empacotamento do depósito, sendo disperso, quando os bioclastos não se tocam, fraco, quando os bioclastos se 
tocam nas extremidades ou quando rotacionados toquem nos demais bioclastos e denso, quando há toque entre os bioclastos e pouca matriz entre eles (Anexo A).

Em observações prévias ao estudo foram definidas as assinaturas tafonômicas. A condição dos bioclastos é definida pela abrasão, desgaste mecânico dos bioclastos, caracterizado por fragmentação das arestas e porções mais sensíveis, como as bordas das conchas; corrosão, caracterizada pelo desgaste químico, como dissolução da superfície do bioclasto, com redução da superfície; e bioerosão, provocada por outros organismos vivos, como a presença de perfurações nas conchas.

A textura alterada é identificada pela ausência de marcas das linhas de crescimento e presença de porosidade, às vezes pode ser confundida com a corrosão; a coloração em alguns casos é representada por manchas ou detalhes da coloração original que ficaram preservadas, mas com diferenciações, as conchas também podem estar completamente brancas.

A fragmentação foi distribuída em intervalos: sem fragmentação, menor de $10 \%$, entre 10 e $50 \%$, entre 50 e $90 \%$ e maior que $90 \%$ da superfície do bioclastos.

A condição dos bioclastos e a fragmentação foram analisadas de acordo com a posição de ocorrência, definida a partir da análise morfológica dos bioclastos. A textura, coloração, friabilidade, orientação e fragmentação foram analisadas também de acordo com o taxon.

A observação destas assinaturas tafonômicas foi feita por camadas com cerca de 1,5 cm de profundidade na superfície do bloco analisado, de acordo com recomendação de Simões \& Ghilardi (2000), método utilizado por Ghilardi (2004). O sedimento foi retirado manualmente com auxílio de pinças e instrumentos de perfuração e escavação (Figura $11 \mathrm{c}$ ). Para efeito de comparações foram feitas as mesmas análises na face norte do bloco em perfil, considerando o ápice como $0^{\circ}$, neste caso as análises foram separadas por horizontes de aproximadamente $5 \mathrm{~cm}$ (Figura 11).

A análise morfológica dos gastrópodes do gênero Pomacea foi baseada em Estebenet (1998), que identificou em indivíduos de Pomacea canaliculata viventes, uma relação de crescimento entre as variáveis analisadas, sendo a altura do ápice, a altura da abertura, a largura máxima da concha, a largura máxima da abertura e a altura máxima da concha (Figura $05)$.

Demais gastrópodes de morfologia semelhante à de Pomacea foram analisados considerando-se as mesmas variáveis morfológicas, para saber se ocorrem relações entre as variáveis morfológicas e o crescimento das conchas da mesma forma que acontece para 
Pomacea. No caso dos gastrópodes da Família Planorbidae, gênero Biomphalaria, e conchas de morfologia semelhante, foram considerados apenas o diâmetro da concha, a altura da abertura (Sph) e largura máxima nas análises morfométricas (Figura 12). Quando encontrados outros gêneros a morfologia foi analisada seguindo o mesmo padrão de variáveis.
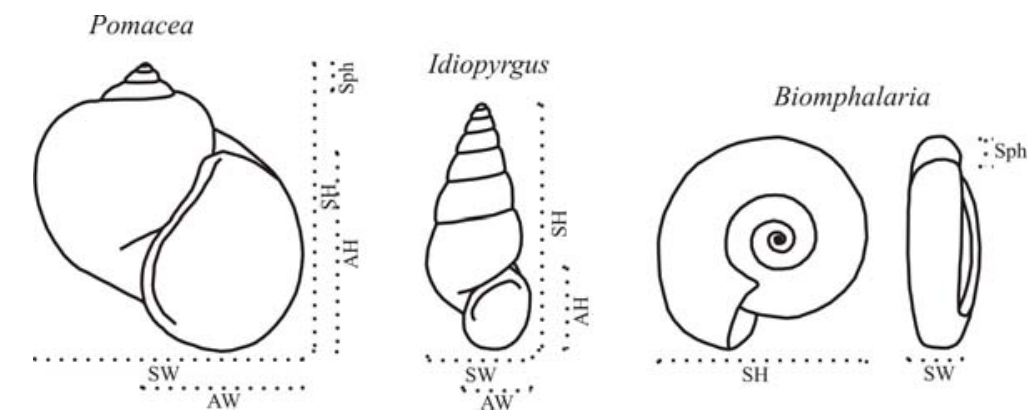

SpH: altura do ápice

$S H$ : altura da concha

$A H$ : altura da abertura

$S W$ : largura da concha

$A W$ : largura da abertura

Figura 12 - Variáveis morfológicas analisadas dos gastrópodes do gênero Pomacea. Para Biomphalaria Sph é a altura da abertura. Baseado em Estebenet, A. L. (1998).

\subsection{Análises ecológicas}

Os dados obtidos das análises micropaleontológica e tafonômica foram avaliados de acordo com índices ecológicos. Os índices calculados foram diversidade de espécie de Shannon-Weaver, índice de dominância de Simpson e índice de equitatividade de Pielou, como seguem nas fórmulas 1, 2 e 3, segundo Odum (1988).

Para a contagem do número de indivíduos foram considerados apenas aqueles inteiros, quando fragmentados ou desarticulados foram considerados apenas como indivíduos os ápices e uma das valvas (Meyrick \& Karrow, 2007). 


\begin{tabular}{|c|}
\hline $\begin{array}{c}\text { Índice de diversidade de Shannon-Weaver } \\
\mathrm{H}=-\sum \text { pi.lnpi } \\
\text { Onde: pi é a abundância proporcional da espécie } \mathrm{i}=\mathrm{ni} / \mathrm{N} \\
\mathrm{N} \text { é o total de indivíduos } \\
\mathrm{n} \text { é o total de indivíduos de cada espécie }\end{array}$ \\
\hline $\begin{array}{c}\text { Índice de dominância de Simpson } \\
\mathrm{D}=\sum \mathrm{pi}^{2}\end{array}$ \\
\hline $\begin{array}{c}\text { Índice de equitatividade de Pielou } \\
\mathrm{E}=\mathrm{H}^{\prime} / \mathrm{lnS} \\
\text { Onde: } \mathrm{S} \text { é o total de espécies }\end{array}$ \\
\hline
\end{tabular}

\subsection{Outros enfoques estatísticos}

Foi utilizada estatística descritiva dos dados granulométricos e tafonômicos (Witte \& Witte, 2005; Minitab, 2007). Também foi utilizada estatística multivariada, com análise de componentes principais e análise de agrupamento das componentes principais obtidas (Manly, 1994; Hair et al., 2005). Os resultados estatísticos forneceram informações para avaliar a relação entre eles nas interpretações paleoambientais.

Para aplicação da estatística multivariada, análise de agrupamento e análise de componentes principais, os dados devem variar de $-\infty \mathrm{a}+\infty$, por isso foram normalizados conforme citam Pawlowsky-Glahn \& Egozcue (2006) e tratados com método clr, (centeredlog-ratio), descrito por Aitchison (1982) apud Pawlowsky-Glahn \& Egozcue (2006), obtido do ln da divisão da componente, dividida pela média geométrica do conjunto. Os dados composicionais de elementos maiores e menores foram analisados separadamente por análise de agrupamento com método de ligação Ward e medida de distância Euclidiana ao quadrado a partir das variáveis no formato clr. Todas as análises estatísticas foram geradas no programa Minitab 15.1.

Para as análises tafonômicas também foi utilizada estatística descritiva para dados direcionais e realizado teste de uniformidade (teste de Rayleigh), para verificar se os dados seguem a distribuição de Von mises, ou seja, se há direção preferencial na orientação das conchas, segundo orientações de Mardia (1972). O teste de Rayleigh é baseado na magnitude padrão do vetor resultante dos dados obtidos, ou seja, na medida de dispersão normalizada dos dados. 


\section{AFLORAMENTOS ESTUDADOS}

\subsection{Afloramentos da Serra da Bodoquena estudados em laboratório}

Ponto 01 - Mineração Calcário Xaraés

A Mineração Calcário Xaraés localiza-se na Fazenda São Geraldo, no município de Bonito-MS, cerca de $19 \mathrm{~km}$ ao Sul da cidade.

Constitui-se em micrito (calcário fino e pulvurulento), esfarelando-se facilmente nas mãos, por isso chamado pelos mineradores de calcário em pó. O depósito é maciço sem estruturas sedimentares. Segundo informações da indústria exploradora, o calcário retirado tem $45 \%$ de óxido de cálcio, correspondendo a 80,55\% de $\mathrm{CaCO}_{3}$.

O perfil estudado em campo tem cerca de 2,5 m expostos, acrescido de 2,66m, obtidos por meio de amostragem com uso de trado, totalizando 5,16m de perfil, sendo a base representada por $0,01 \mathrm{~m}$. Sobre o depósito há cerca de $1 \mathrm{~m}$ de solo, provavelmente contendo carbonato (Figura 13 e 15 A e B). As amostras receberam um nome relativo à porção do perfil (Figura 15d), esta nomenclatura será utilizada ao longo do texto.

Na porção exposta da lavra foram coletadas amostras a cada 0,5 m do topo para a base, perfazendo um total de 5 amostras, para estudo em laboratório. A partir da base deste corte a tradagem atingiu 2,66m de profundidade, compondo o perfil de 2,66m a 0,01m, desta tradagem foram estudadas oito amostras (Figura 15 D).

São encontrados muitos gastrópodes distribuídos nos cortes expostos pela lavra, identificados pelos gêneros Biomphalaria, Pomacea, Bulimulus e Idiopyrgus. A distribuição do gênero Biomphalaria é aleatória, assim como fragmentos de diversas conchas desde o topo até 3,46m de profundidade, já Idiopyrgus ocorre entre 4,46 e 3,96m. O gênero Pomacea se concentra no topo, com grandes espécimes, acima de 4,46m (Figura 13).

A partir de 1,94m até a base, os gastrópodes aparentemente não ocorrem mais (Figura 13). Em 1,38m a umidade aumenta consideravelmente, mudando de cor o calcário. Não é mais encontrado calcário puro de 1,06m até a base, aparecendo então uma argila maciça de cor castanha bem úmida. Quando se atinge 0,51m, pequenos nódulos carbonáticos aparecem 
no meio da argila, aumentando de tamanho com a profundidade ocorrendo até a base do perfil, onde os nódulos têm diâmetro de até 3 cm, impossibilitando tradagem mais profunda.

Estes nódulos podem ser identificados como oncólitos, pois apresentam crescimento concêntrico ao redor de um núcleo (Figura 14). Segundo Leinfelder \& Hartkopf-Fröder (1990) oncólitos crescem in situ sob condições de baixa energia durante uma pausa na sedimentação. Neste caso algum transporte ocorria, já que alguns oncólitos apresentam crescimento ao redor de todo o núcleo e não apenas em um dos lados.

\section{Perfil Mineração Calcário Xaraés}

\begin{tabular}{|c|c|c|}
\hline Micrito mais claro $\uparrow$ & 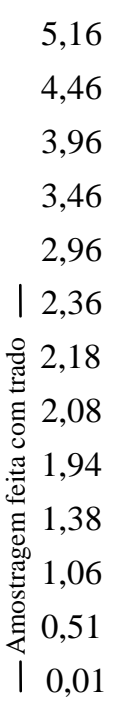 & ^Ausência de macrofósseis \\
\hline
\end{tabular}

Figura 13 - Perfil obtido com informações coletadas em campo.

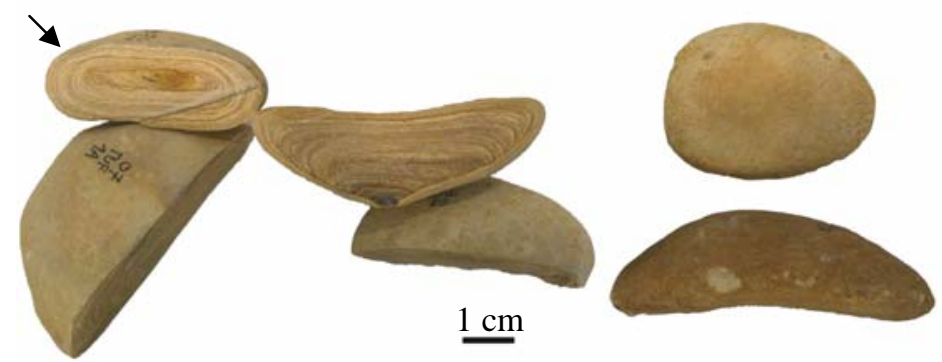

Figura 14 - Oncólitos encontrados na base da lavra de carbonatos da Mineração Calcário Xaraés. O oncólito indicado pela seta apresenta crescimento concêntrico, evidenciando transporte durante seu crescimento, ao contrário do oncólito a sua direita. 

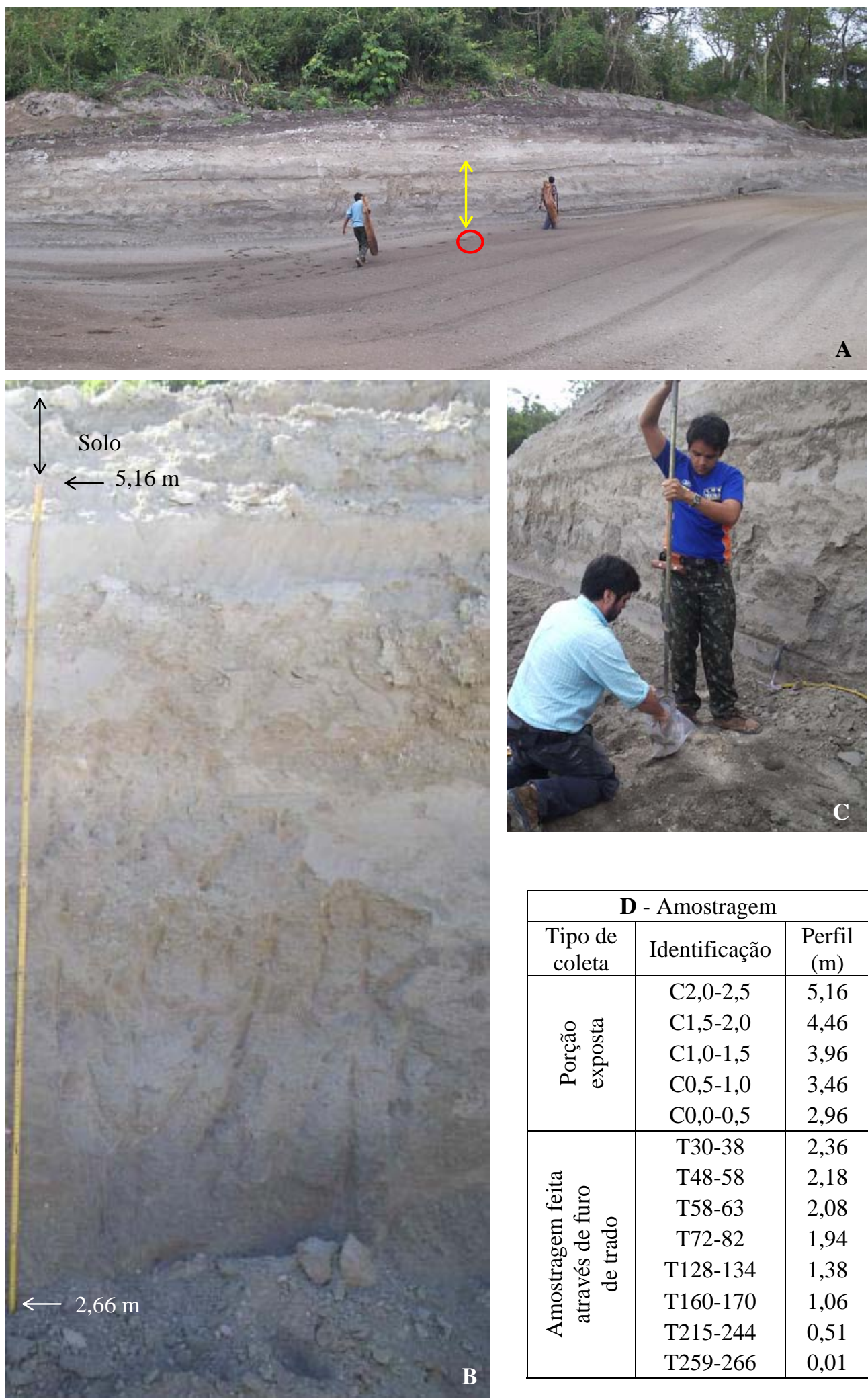

\begin{tabular}{|c|c|c|}
\hline \multicolumn{3}{|c|}{ D - Amostragem } \\
\hline $\begin{array}{c}\text { Tipo de } \\
\text { coleta }\end{array}$ & Identificação & $\begin{array}{c}\text { Perfil } \\
\text { (m) }\end{array}$ \\
\hline \multirow{5}{*}{ 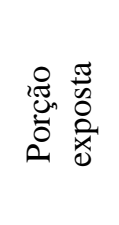 } & C2,0-2,5 & 5,16 \\
\hline & C1,5-2,0 & 4,46 \\
\hline & C1,0-1,5 & 3,96 \\
\hline & $\mathrm{C} 0,5-1,0$ & 3,46 \\
\hline & $\mathrm{C} 0,0-0,5$ & 2,96 \\
\hline \multirow{8}{*}{ 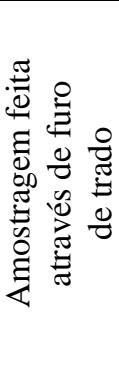 } & T30-38 & 2,36 \\
\hline & T48-58 & 2,18 \\
\hline & T58-63 & 2,08 \\
\hline & T72-82 & 1,94 \\
\hline & T128-134 & 1,38 \\
\hline & T160-170 & 1,06 \\
\hline & T215-244 & 0,51 \\
\hline & T259-266 & 0,01 \\
\hline
\end{tabular}

Figura 15 - Mineração Calcário Xaraés, Faz. São Geraldo. A) Visão geral da área de coleta na mineração. B) Corte amostrado representado em uma coluna amarela na figura A. C) Amostragem por método de tradagem, local representado por um círculo vermelho na figura A, notar calcário mais claro proveniente da tradagem sobre calcário mais escuro da porção exposta. D) Amostragem em campo, as amostras coletadas representam o perfil à direita, C: corte, T: Tradagem. 
Em segunda visita feita a Mineração Calcário Xaraés a lavra não sofreu avanços com a exploração, apenas rebaixamento até próximo ao nível com argilas vermelhas (Figura 16 A). Não se notou nenhuma diferença no afloramento após as novas retiradas de carbonato pela exploração.

No terreno acima da lavra há vegetação densa e alta (Figura 16B). A camada de solo possui aproximadamente $1 \mathrm{~m}$ de espessura, sendo um carbonato em processo de pedogênese.
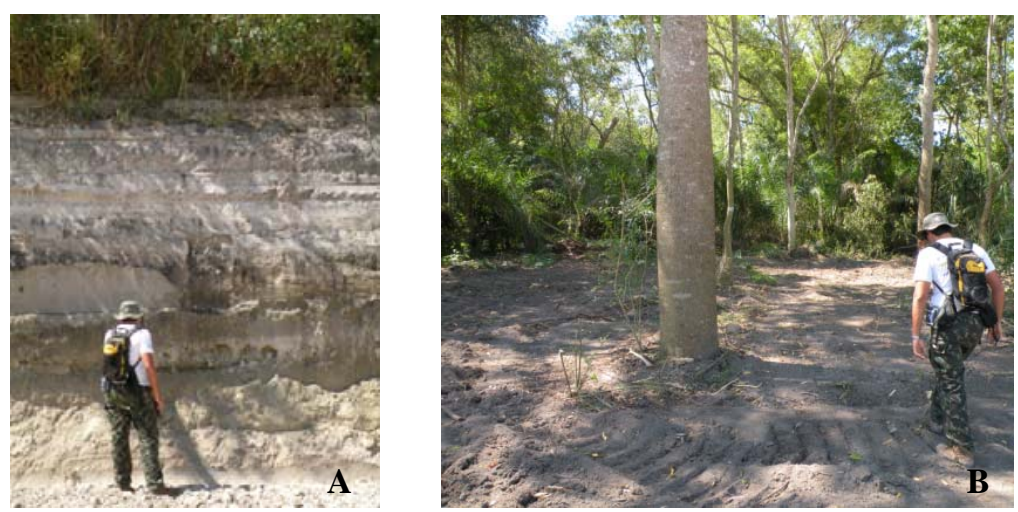

Figura 16 - Lavra da Mineração Calcário Xaraés. A) Exposição no mesmo local de coleta anterior, apenas com maior profundidade. B) Área sobre o depósito depois de retirada da vegetação.

Em área de antiga exploração da própria Mineração Calcário Xaraés já esgotada, o pouco de carbonato deixado foi intemperizado, apresentando coloração desde branco até preto na superfície (Figura 17). Aparentemente mais litificado pelo resultado da dissolução do carbonato e recristalização nos espaços da própria rocha.
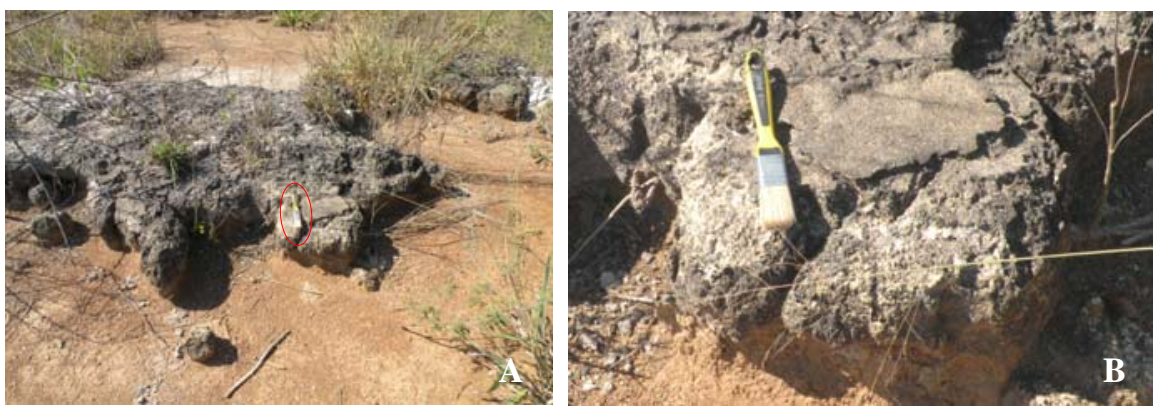

Figura 17 - Micritos intemperizados sobre argila vermelha. A) Micritos de antiga área de exploração da Mineração “Calcário Xaraés”. Círculo vermelho indica pincel e posição de B) Detalhe da área da figura A.

Esta exposição esta distante da exploração atual cerca de $800 \mathrm{~m}$, e continua sobre as argilas vermelhas (Figura 17) encontradas na primeira coleta no afloramento. O depósito 
07TUF16, antiga mineração no centro da cidade de Bonito, apresenta rochas com estas mesmas características, demonstrando a ação do intemperismo sobre os micritos.

Ponto 04 - Cachoeiras do Mimoso

Próximo à margem esquerda a montante do Rio Mimoso, na Fazenda do Rio Mimoso, há uma área de maior elevação dominada por vegetação, parte em processo de erosão devido à abertura de trilhas, e decomposição por domínio de vegetação (Figura 18 A). Este afloramento é um micrito inconsolidado de cor acinzentada, diferente daquele formado em quedas de água, é inconsolidado e apresenta muitos moluscos, assemelhando-se ao da mineração Calcário Xaraés.

São encontrados gastrópodes no depósito. Ao contrário dos demais pontos, onde foram encontrados só gastrópodes, aqui também são encontrados bivalves (Figura 18 B).
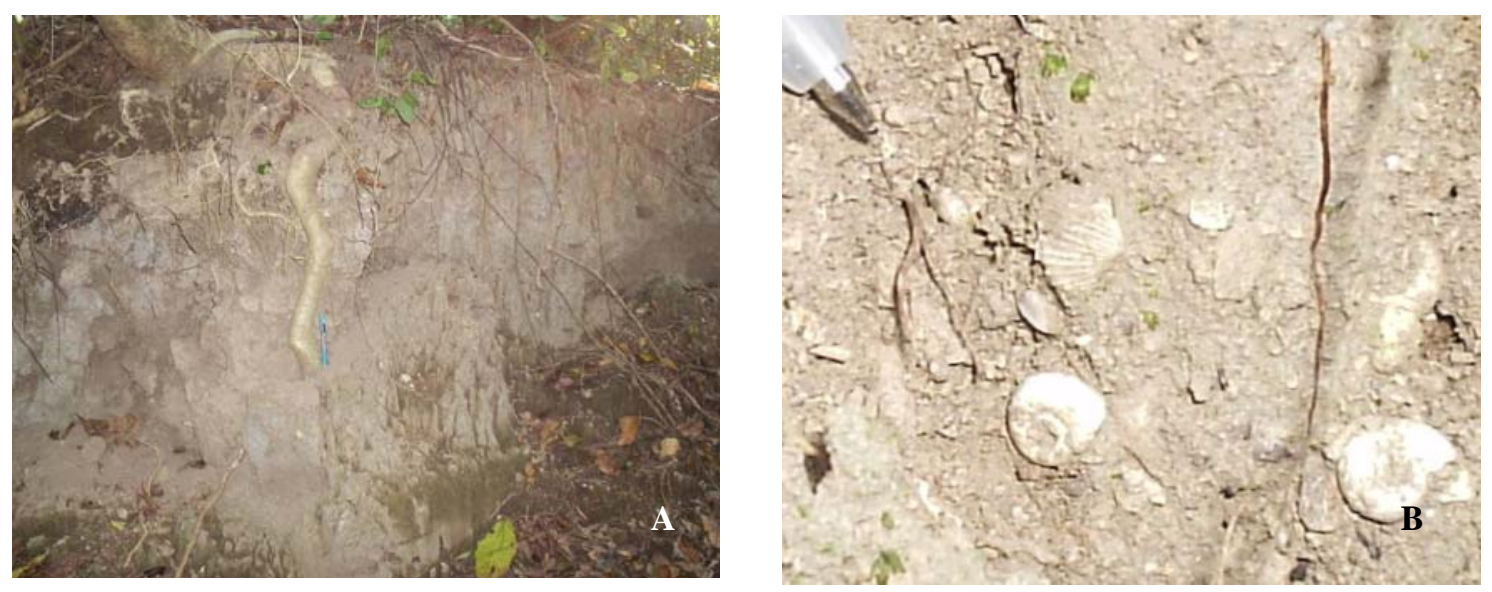

Figura 18 - A) Área de coleta. Visão do afloramento em processo de erosão e decomposição devido ao domínio de vegetação, notar o crescimento de raízes. B) Gastrópodes e bivalves encontrados.

Ponto 06 - Cachoeiras do Mimoso

Ainda na Fazendo do Rio Mimoso, em área desprovida de mata natural e terreno plano, mas em relação ao Rio Mimoso de maior altitude, o solo tem grande porção de rocha carbonática em decomposição. 
O solo tem coloração acinzentada e apresenta moluscos como a rocha calcária encontrada na mineração Calcário Xaraés, mas é micrito mais compacto, sem o aspecto pulverulento. Nesta área há gastrópodes aflorando sobre o solo (Figura 19). A poucos metros deles, tufas com folhas são encontradas. Provavelmente é o mesmo depósito de micritos do ponto 04, pois são muito próximos, mas sobrepõem-se a ele, devido a maior elevação.
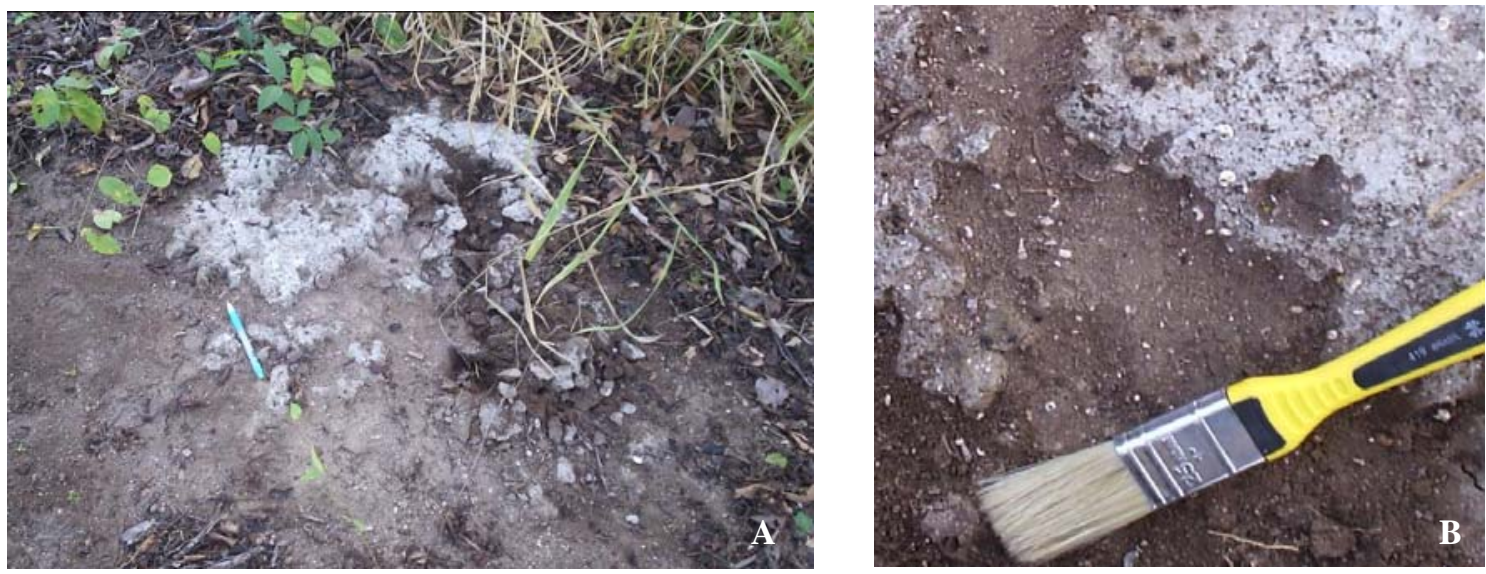

Figura 19 - Área de coleta do ponto 06, Cachoeiras do Mimoso. A) Rocha carbonática aflorante. B) Gastrópodes, pontos brancos, são encontrados neste afloramento bem incrustados nas tufas.

Ponto 07 - Rio Seputa

No leito do Rio Seputa, afluente do Rio Perdido, ocorrem depósitos de tufas calcárias atuais nas quedas de água e no leito do rio. Neste ponto há um sumidouro (Figura 20 A). A água é límpida e com correnteza considerável, formando pequenas piscinas após as quedas de água. O fluxo de água é suficiente para transportar folhas, que podem se fixar nos tufas nas áreas de queda de água, formando tufa do tipo fitoclásticas. Como o mês de julho se caracteriza por pouca pluviosidade, há exposição de tufas sofrendo processos de intemperismo (Figura 20 B, C).

Macroalgas filamentosas e algas caráceas ocorrem em parte do leito do rio. Tais algas realizam o processo de fotossíntese liberando $\mathrm{O}_{2}$ dentro da água, formando bolhas que são recobertas pelo carbonato. Em tufas inativas ocorrem bolhas muito semelhantes a estas, no entanto, é provável que sua origem não seja a mesma, pois também ocorrem em tufas com folhas, e neste caso as algas estavam isoladas de qualquer outro tipo de fragmento (Figura 20 D). 
Nas margens do rio ocorrem depósitos de tufas calcárias micríticas com gastrópodes. A rocha é mais compacta e tornam-se friáveis com o intemperismo pela água. Ora os sedimentos possuem coloração acinzentada, ora mais acastanhada.

Os gastrópodes também ocorrem na queda de água, provavelmente atuais. Algumas conchas foram encontradas sobre as tufas na área seca próxima à queda, provavelmente com a chegada da água a esta região poderiam ser recobertas pelo carbonato. No entanto, este depósito aparenta ser erodido pela água que corre hoje, e não um sistema de deposição.
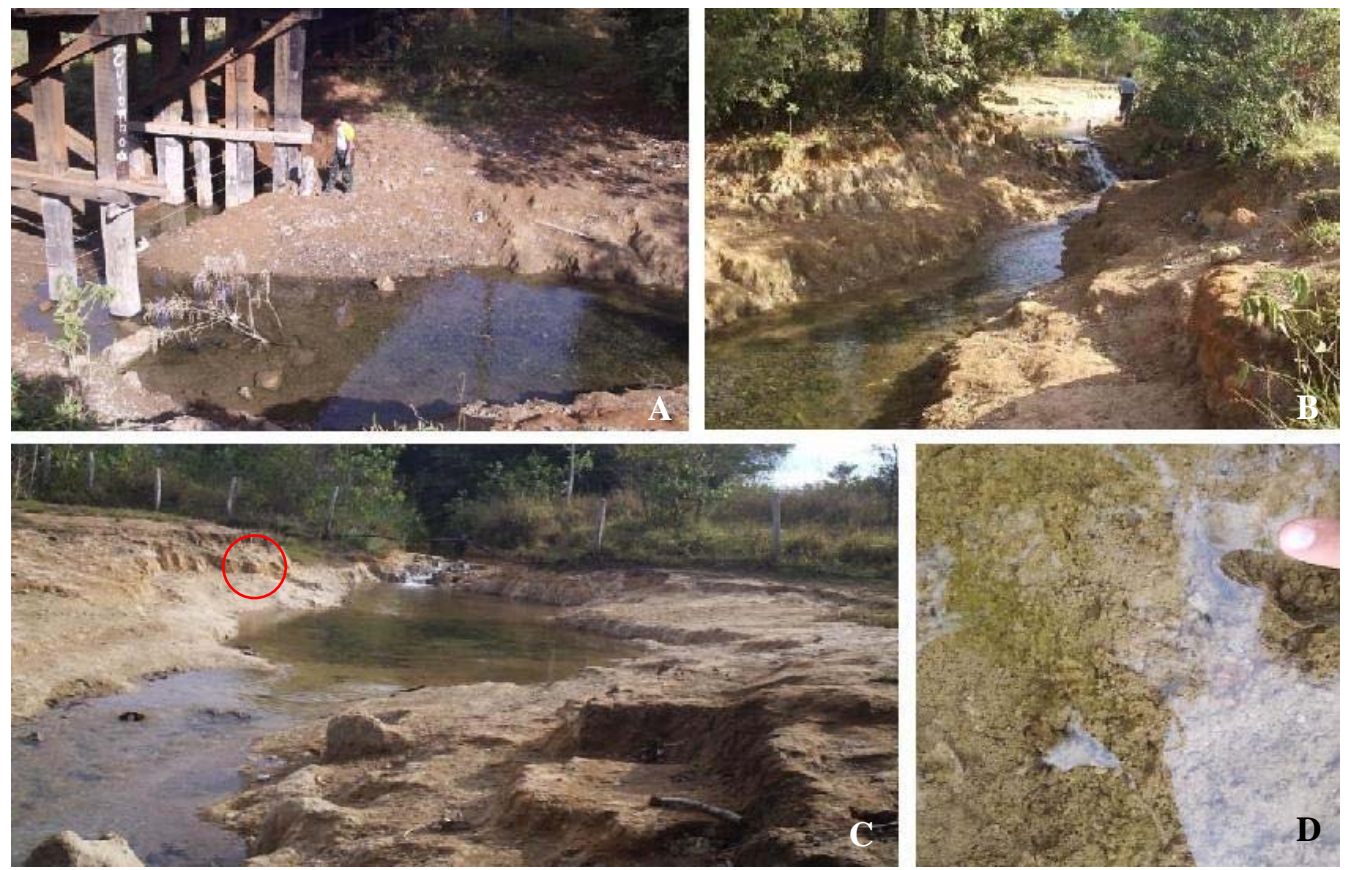

Figura 20 - Depósito do ponto 07, Rio Seputa. A) Sumidouro do Rio Seputa. Notar nas figuras A, B e C as margens sem vegetação com a rocha exposta. Em períodos de chuva ela deve ficar coberta pela água. C) Círculo vermelho indica área de coleta. D) Macroalgas filamentosas produzem bolhas de gás carbônico que são recobertas pelo carbonato.

Ponto 14 - Rio Campina

O Rio Campina, local bastante modificado pelos moradores, mostra sinais de erosão nas margens, com construções muito próximas a ele, que provavelmente liberam esgotos em seu leito, acidificando a água, promovendo a dissolução dos micritos.

Este rio possui fluxo lento, apesar do grande volume de água. São encontrados gastrópodes nas suas margens em um depósito micrítico pouco poroso de cor cinzenta (Figura 21). Algumas algas caráceas são vistas nas margens do rio. 


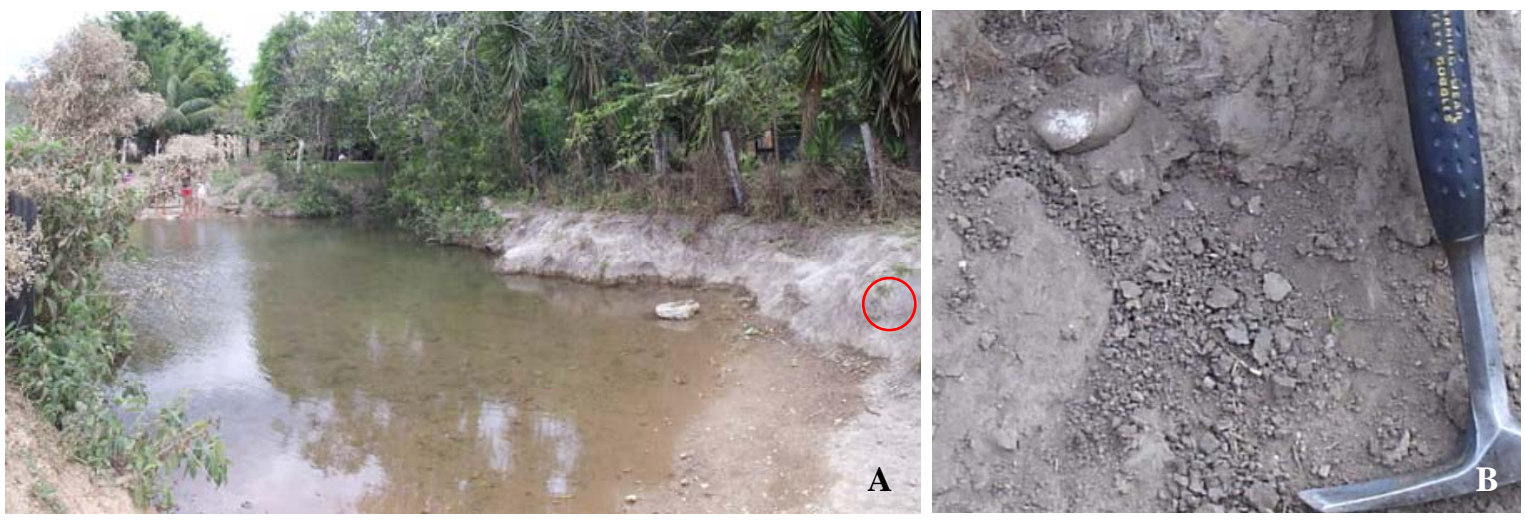

Figura 21 - Rio Campina. As margens erodidas expõem gastrópodes em um depósito calcário cinzento. Círculo vermelho indica área de coleta em detalhe em B) Acima e a esquerda da figura um gastrópode.

Ponto 16 - Antiga Mineração de carbonatos

Na cidade de Bonito em uma antiga mineração de carbonato encontram-se gastrópodes em depósitos similares aos vistos às margens dos rios de Bodoquena, formando um solo de cor esbranquiçada, um paleosolo de micritos (Amostra 16B) (Figura 22 A e B).

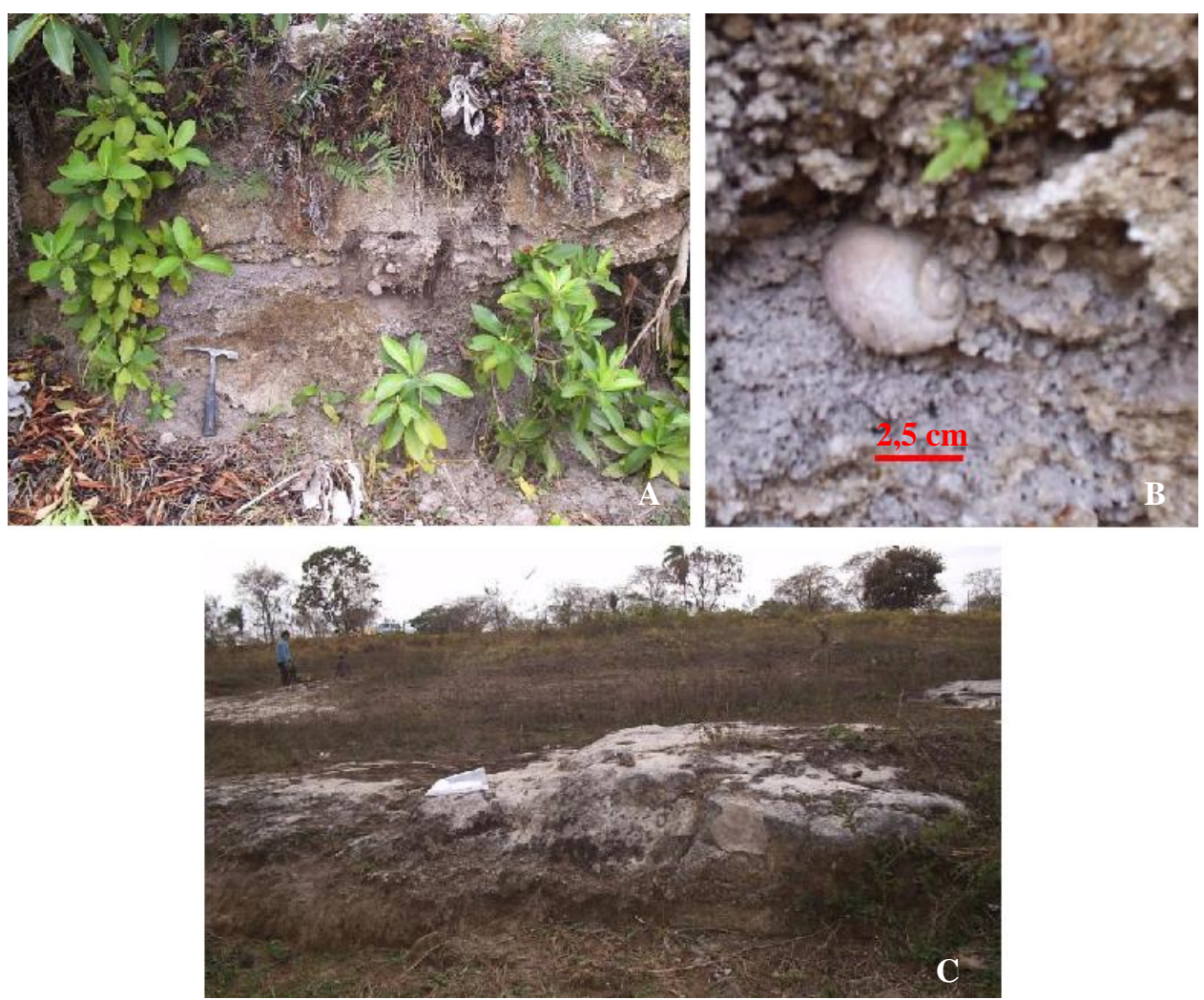

Figura 22 - Antiga mineração de carbonato. A) Solo de carbonato exposto, 07TUF16B. B) Detalhe do depósito com gastrópodes. C) Calcário compacto e denso na mesma área, 07TUF16D. 
Há um outro afloramento de carbonato na mesma área com características diferentes do anterior, é compacto, denso e cinzento (Figura 22 C). Provavelmente seria o mesmo depósito intemperizado pela água das chuvas, tornando-o um micrito sem porosidade (Amostra 16D), esta em nível inferior do que o depósito em processo de pedogênese (Amostra 16B). Podem ter sofrido dissolução e reprecipitação no interior do próprio depósito, já que estavam expostos, motivo pelo qual não foram encontrados gastrópodes. É um micrito endurecido, classificado por Oliveira (2009) como um calcrete.

\subsection{Afloramentos estudados em campo}

Os afloramentos a seguir descritos não foram submetidos às análises propostas, mas são de interesse para comparações e estudos futuros.

\subsubsection{Serra da Bodoquena}

Ponto 02 - Rio Formoso

A Rodovia MS-365 cruza o Rio Formoso, onde aparentemente não ocorrem tufas calcárias em formação. É um rio de águas límpidas, de pouco volume e profundidade de água, formando um pequeno remanso neste ponto, que segue com pequena correnteza (Figura 23 C). No leito do rio são observados nódulos carbonáticos, semelhantes àqueles encontrados no ponto 01, na Mineração Calcário Xaraés.

Ponto 03 - Cachoeiras do Mimoso

Na Fazenda do Rio Mimoso há várias cachoeiras ao longo do curso do rio. Ao lado de uma das quedas, com tufas fitoclásticas atuais, há uma tufa fitoclástica fóssil (Figura 24 A). Esta tufa tem coloração mais castanha, com maior compactação e a presença de muitos 
vestígios vegetais, principalmente folhas (Figura 24 B e C). Ao longo do rio há formação de tufas atuais.
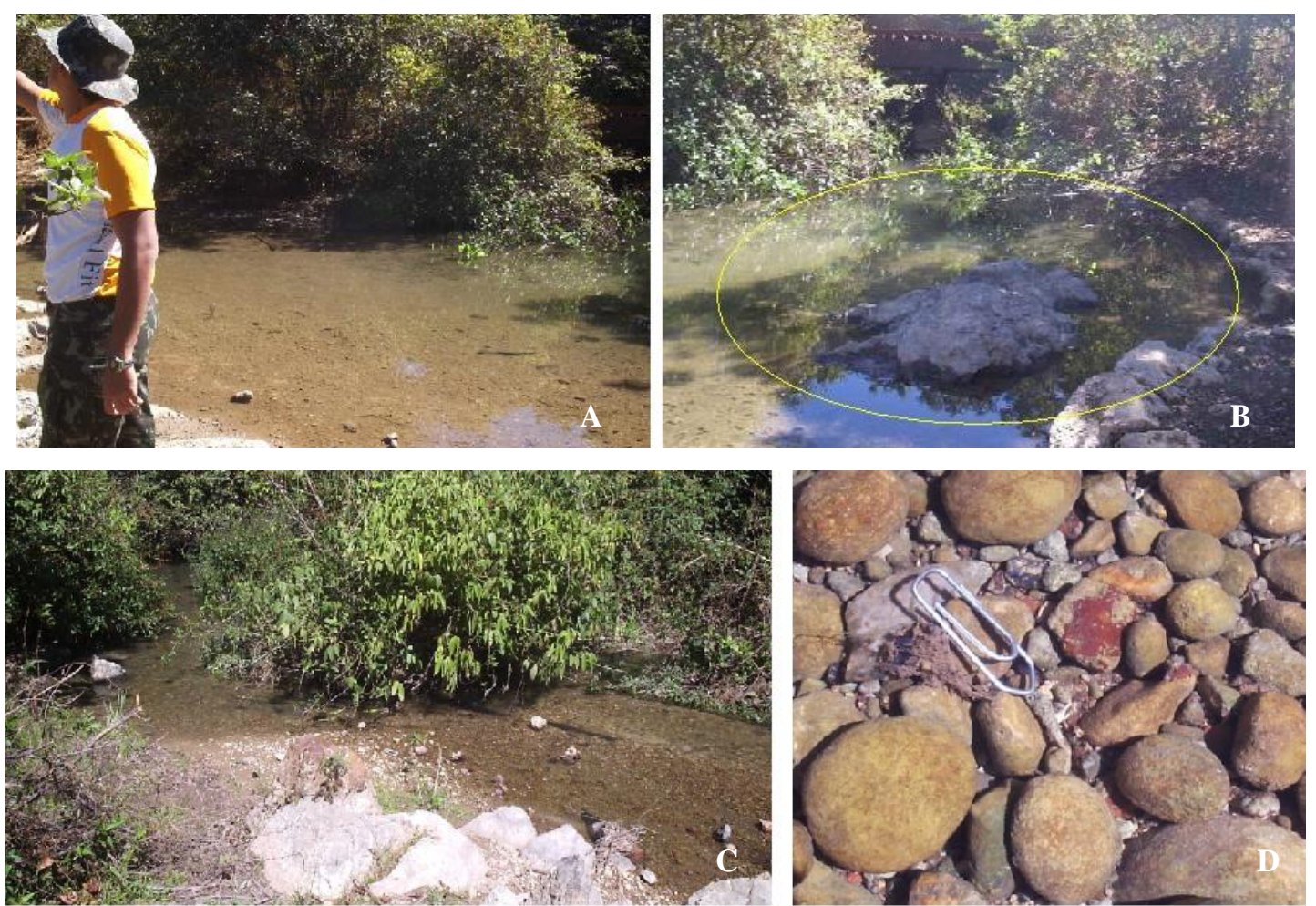

Figura 23 - A e B) Área de remanso do Rio Formoso. Em B a elipse amarela define a área onde são encontradas algas. C) Área de fluxo após o remanso, a direção da corrente da água é da direita para a esquerda. D) Gastrópode destacado por um clipe, ao redor nódulos carbonáticos que recobrem todo o solo na figura C.

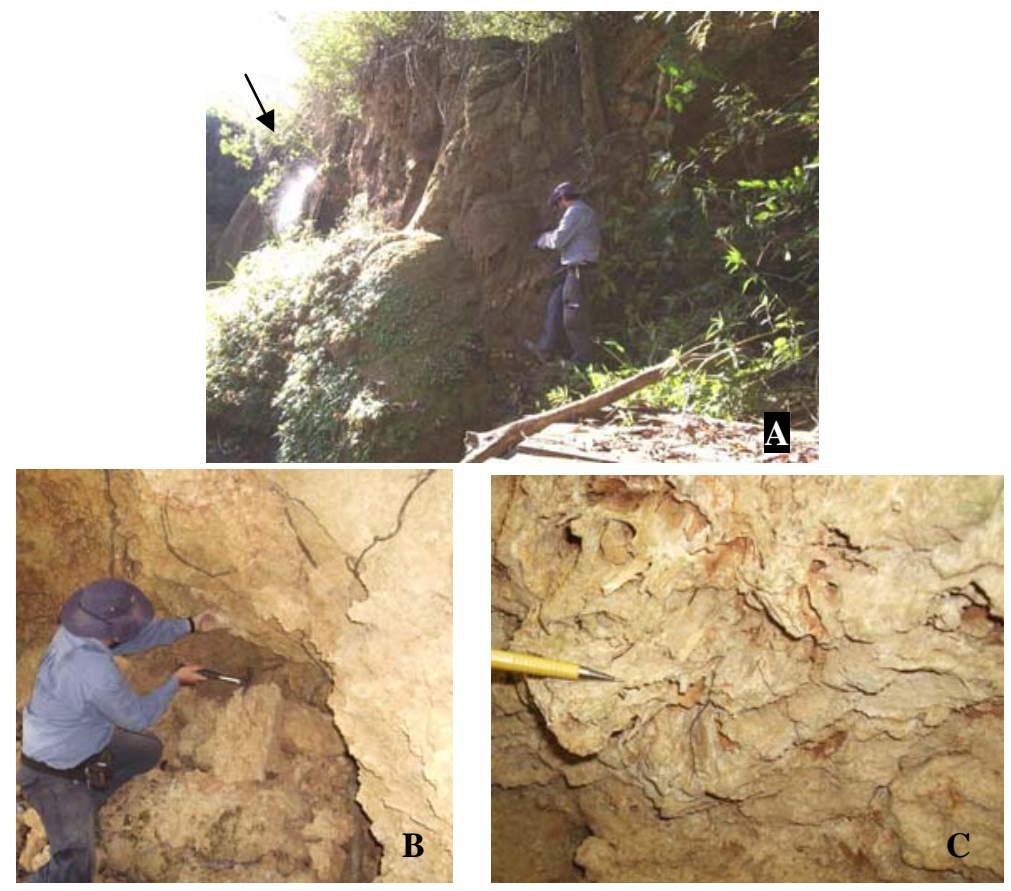

Figura 24 - A) Tufa de cachoeira fóssil próximo à queda atual à esquerda (seta). B) Detalhe do afloramento. C) Tufas calcárias fósseis com vestígios de vegetais, áreas mais escuras são folhas. Detalhe da figura B. 
Ponto 05 - Cachoeiras do Mimoso

Caverna formada de tufas calcárias em área atualmente inativa (Figura 25). Nas áreas adjacentes à caverna foram coletados gastrópodes atuais sobre o solo, porém mortos, mas que auxiliarão a identificar possíveis conchas nos tufas calcárias fósseis.
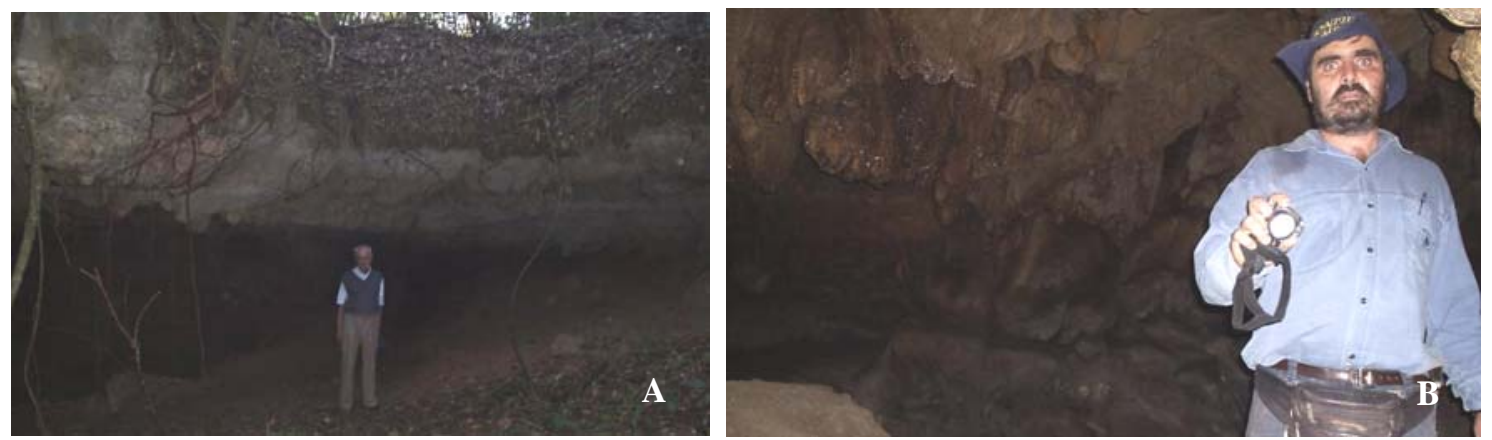

Figura 25 - Caverna formada por tufas calcárias. A) Caverna formada por tufas calcárias na Fazenda do Rio Mimoso. B) Detalhe do interior da caverna.

Ponto 11 - Estrada para Fazenda Baia das Garças

Neste ponto os tufas calcárias fitoclásticas ocorrem nas margens da estrada, que cortou o deposito ao meio. É um depósito mais compacto, denso e esbranquiçado. Não ocorrem gastrópodes, apenas restos vegetais, com preservação de folhas (Figura 26). Segundo Cristalli (2006) para que ocorra este tipo de preservação é necessário volume de água intermitente, ou seja, situação de quedas de água que ocorreram neste local. Em parte do depósito não ocorrem restos vegetais, o sedimento é semelhante ao encontrado no ponto 7, está endurecido, mas algumas áreas intemperizados tornam-se friáveis.
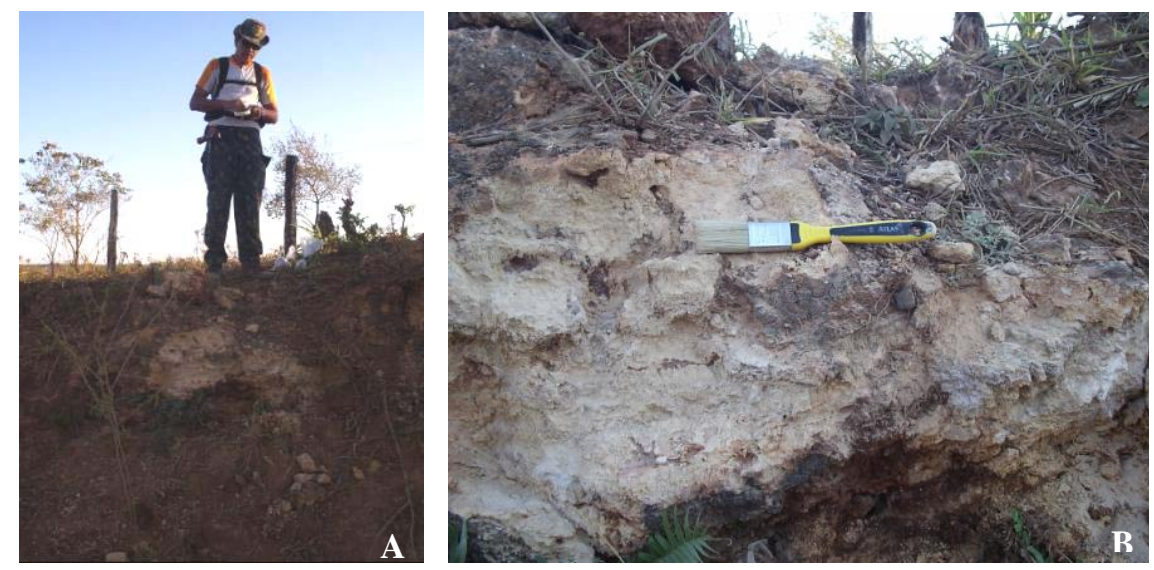

Figura 26 - Depósito de tufas calcárias fósseis. Não há gastrópodes nesta área, apenas folhas. 
Ponto 12 - Rio Betione - Balneário Cabeceira do Betione

No município de Bodoquena, o Rio Betione exibe tufas com características diferentes dos demais pontos visitados. O Rio possui quedas de água com fluxo intenso, mesmo no mês de julho, mês característico de pouca pluviosidade. A vegetação às margens do Rio é mais densa e alta, sombreando as águas (Figura 27 A).

Não são vistas macroalgas filamentosas, nem algas caráceas nesta área, já que ocorrem em áreas de menor fluxo de água. As rochas carbonáticas que se formam nas quedas têm aspecto rugoso, com superfície esverdeada (Figura 27 B e C). Sallun et al. (2007) identificaram rochas semelhantes a estas como estromatólitos recentes, formados por cianobactérias, com conchas de gastrópodes e núcleos rochosos (pisólitos ou oncólitos) em seu interior no Rio Formoso em Bonito, que ocorrem nas mesmas condições de águas límpidas e com alto teor de carbonato dissolvido das tufas calcárias. Tipo de tufa estromatolítica segundo Pedley (1990).
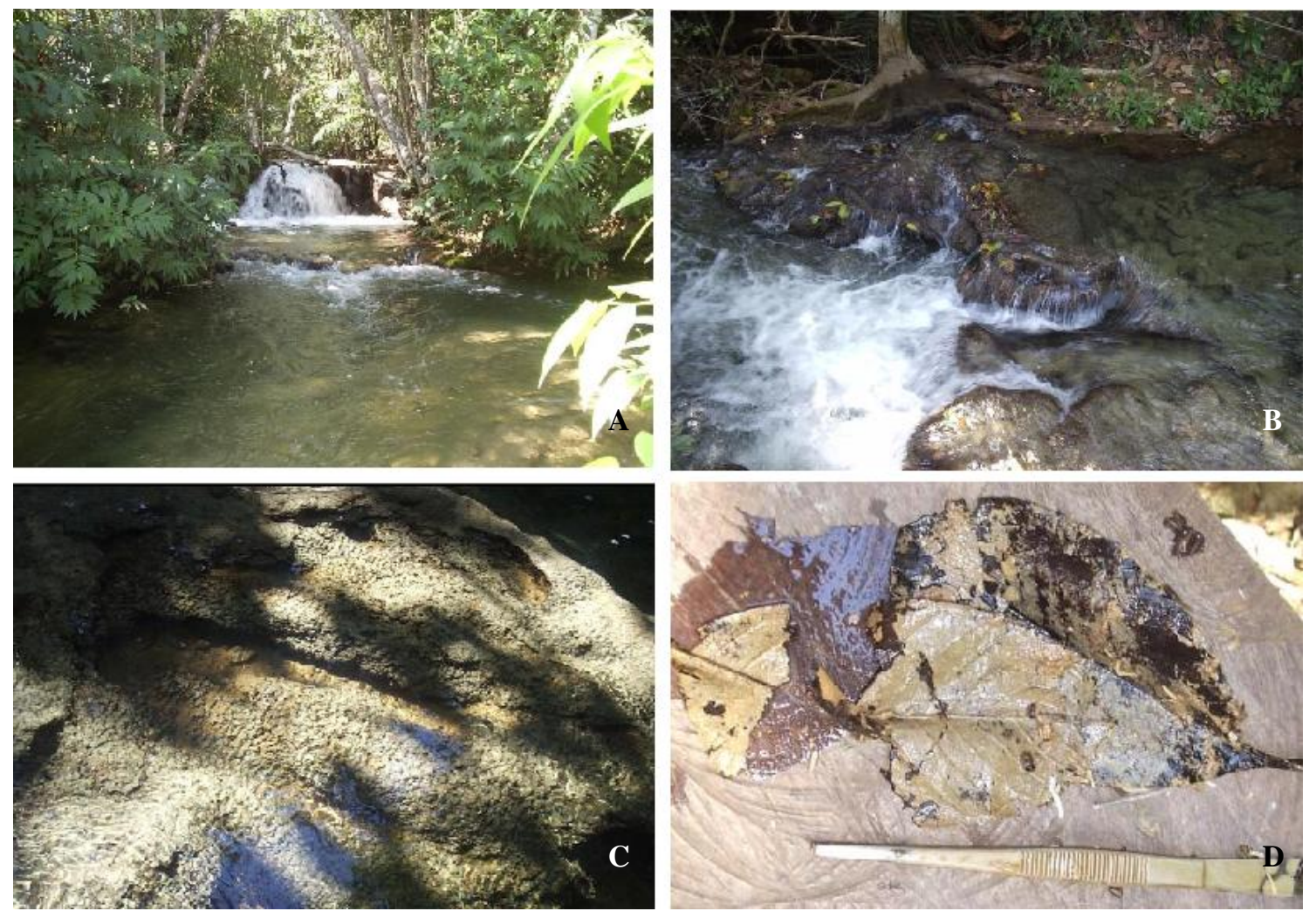

Figura 27 - Rio Betione. A) Queda de água, notar o fluxo e o volume de água. B) Queda de água com folhas fixas na porção superior da queda. C) Tufa calcária com aspecto rugoso e esverdeado. D) Folhas ainda com matéria orgânica recobertas por carbonato. 
Alguns musgos são encontrados sobre os tufas dentro da água, em locais com fina lâmina de água, mas aparecem em maior quantidade nas margens.

Há formação de tufas calcárias também no leito do rio, em geral nas áreas anteriores às quedas de água, com aparência similar aos de cachoeiras. Folhas são vistas presas nestas quedas de água e nas margens, algumas ainda verdes, as mais superficiais não possuem deposição de carbonato, indicando o transporte recente. Aquelas que chegaram há mais tempo aparecem com uma camada de carbonato na superfície (Figura 27 D).

As folhas observadas nesta situação não estão completamente decompostas, mostrando a rápida precipitação do carbonato. Após a precipitação do carbonato sobre a folha depositase uma nova folha sobre esta camada, e inicia-se novamente o processo, formando um pacote carbonático contendo impressões foliares. Provável processo de formação das tufas de cachoeira com preservação de folhas.

As águas são límpidas nas áreas de menor profundidade, ocorrendo principalmente próximo às quedas de água. Nos locais com maior profundidade as águas são limpas, mas não é possível observar o fundo do leito do rio através delas.

Nas áreas de queda de água não são encontrados gastrópodes, no entanto, em uma área anterior a uma das quedas, são observados alguns indivíduos mortos no fundo de uma represa formada pelas tufas, e também poucos indivíduos nas margens do rio (Figura 28 A). A ausência de gastrópodes marca as tufas fósseis formados em quedas, diferentemente daqueles formados em águas lóticas, provável situação ocorrida na Mineração Calcário Xaraés.

Em uma ilha na outra margem do Rio, o solo contém carbonato e muitos gastrópodes (Figura 28 B), é possível observá-los durante toda a trilha. Isto indica antigos locais de deposição do carbonato, que podem ter sido formados durante épocas de inundação ou aumento de correnteza destas áreas, mudança no leito do rio, ou ainda atual local de vida destes moluscos. 

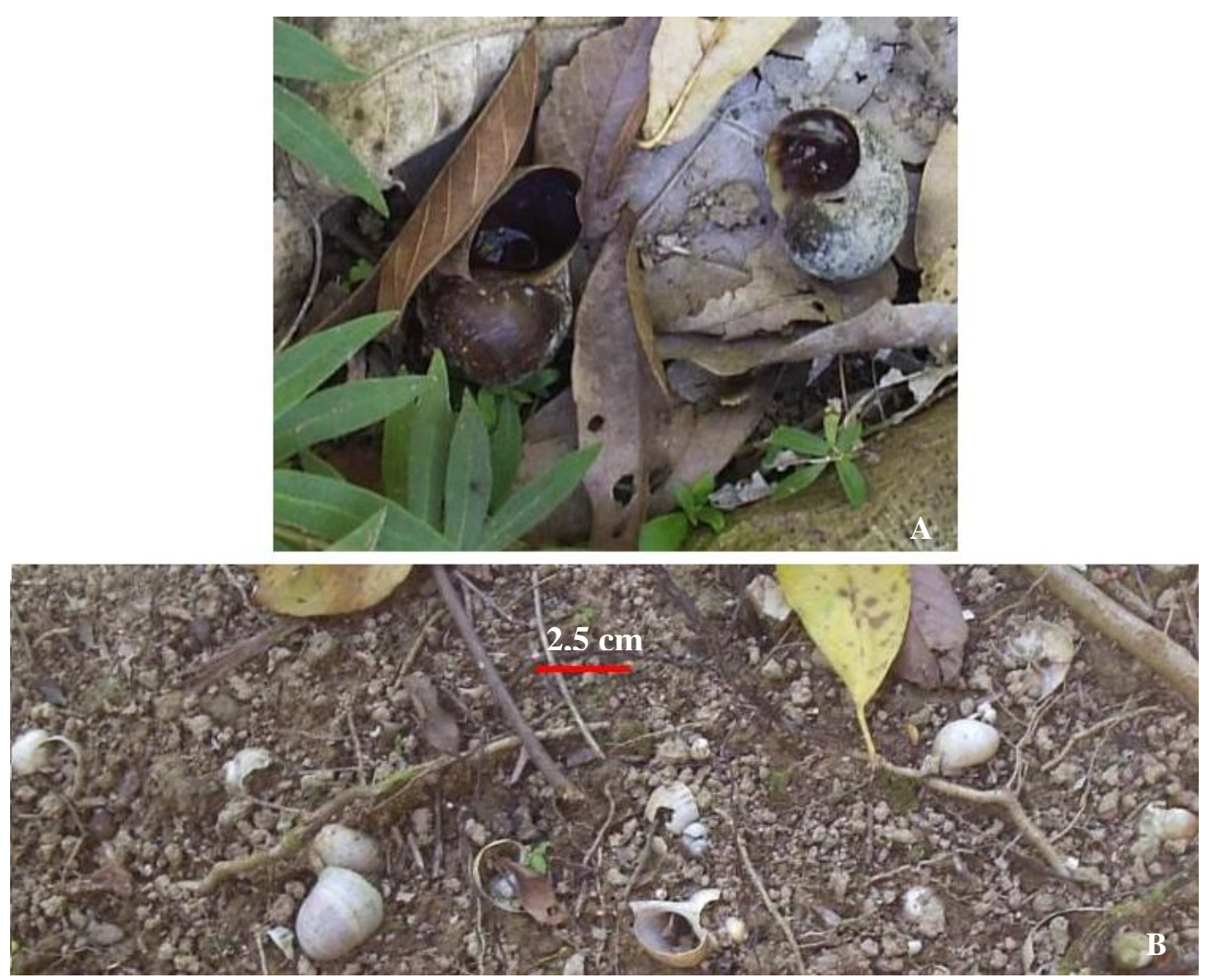

Figura 28 - Gastrópodes encontrados no primeiro ponto do Rio Betione. A) Gastrópodes atuais mortos nas margens do rio. B) Solo expondo gastrópodes em antigos depósitos de carbonato.

Ponto 13 - Balneário Pôr do Sol

Este ponto é continuação do Rio Betione. As tufas calcárias possuem as mesmas características do ponto anterior, assim como tufas estromatolíticas, porém, com maior volume de água em alguns pontos (Figura 29).

Os gastrópodes também não aparecem nas quedas de água, e não foram encontrados indivíduos mortos.

Em um dos locais com escada para se chegar até o rio há um corte na margem, expondo gastrópodes (Figura 30). Aparentemente são equivalentes aos encontrados às margens do ponto anterior. 

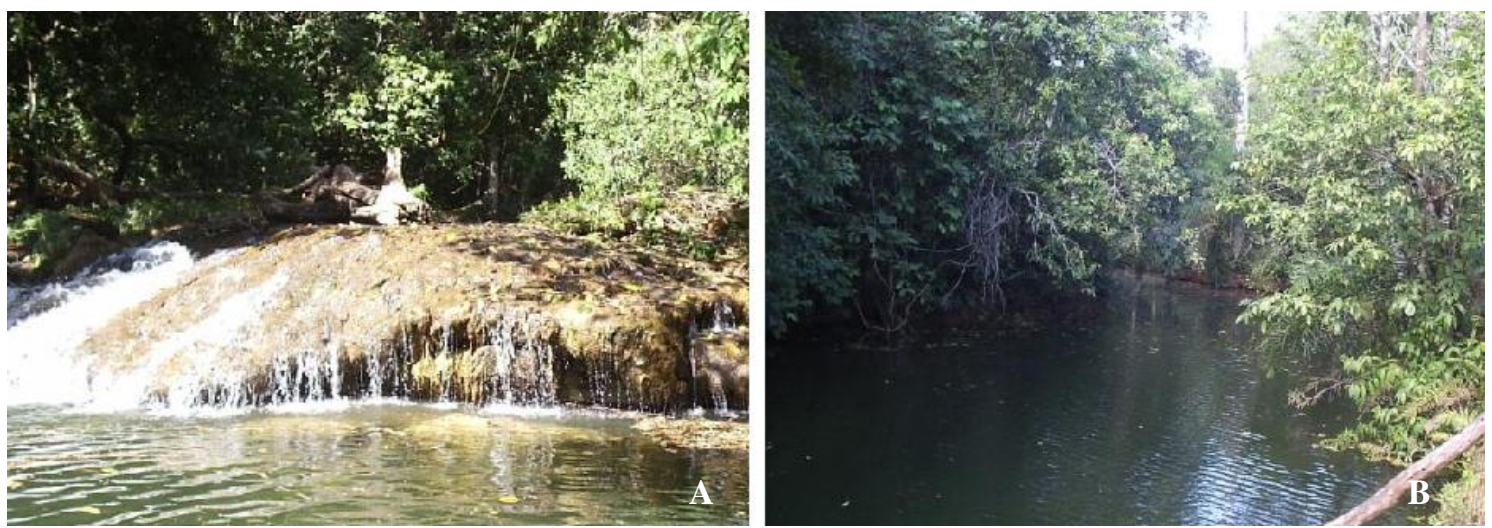

Figura 29 - Rio Betione no ponto 13. A) Queda de água. B) Rio após uma das quedas de água. Notar o volume de água e vegetação.

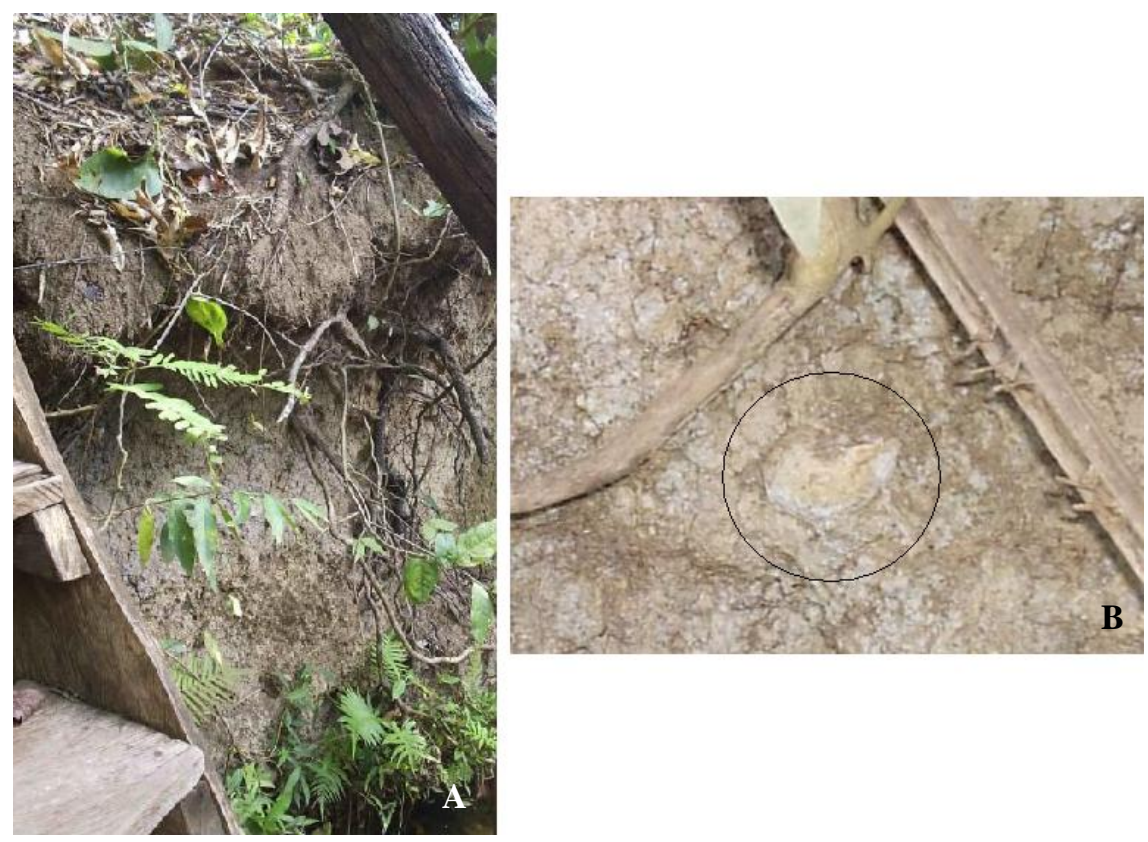

Figura 30 - Balneário Pôr do Sol. Área com gastrópodes. A) Corte próximo a margem com exposição de gastrópodes. B) Gastrópode destacado com círculo encontrado no local.

Ponto 15 - Balneário Municipal Prudente Corrêa

Neste ponto também há semelhança com os pontos 12 e 13 em relação às tufas de quedas de água e estromatolíticas. O fluxo de água é lento, mas com volume grande, no entanto, com menor limpidez da água que os pontos anteriores (Figura 31 A e B). 
Alguns gastrópodes são vistos ao longo da trilha, apesar disso, aparentam terem sido transportados para a construção das trilhas do local com o solo (Figura 31 C).
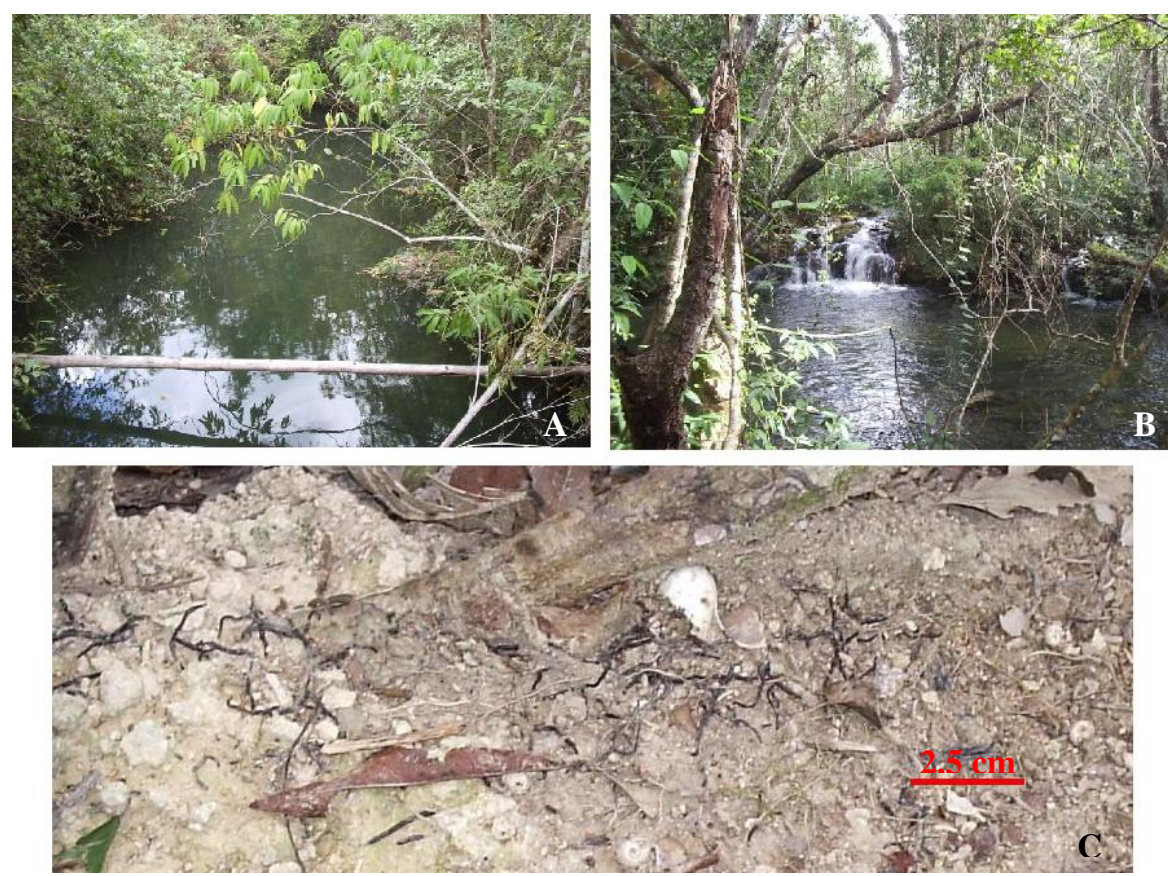

Figura 31 - Balneário Municipal Prudente Corrêa. A e B) O rio possui grande volume de água, mas pouco fluxo. C) Calcário com gastrópodes.

Ponto 17 - Rio Formoso - Camping Poliana

O Rio Formoso neste ponto possui grande volume de água e fluxo lento após a queda de água. A limpidez é grande, a luz do sol atinge o fundo do rio principalmente nas margens, onde se desenvolve grande quantidade de macroalgas filamentosas. Nas áreas mais profundas a cor da água é verde, mas ainda translúcida (Figura 32). Muitos peixes vivem nesta área.

Diminutos tubos calcários de coloração bege são vistos no fundo do rio e em toda a área da margem, provavelmente pela deposição do carbonato sobre as macroalgas.

Gastrópodes mortos estão no fundo do rio próximos às margens. Nas áreas mais altas, próximas às margens, existem depósitos de carbonato contendo tubos calcários e gastrópodes, provavelmente formando um depósito de tufa detrítica (Figura 33). 

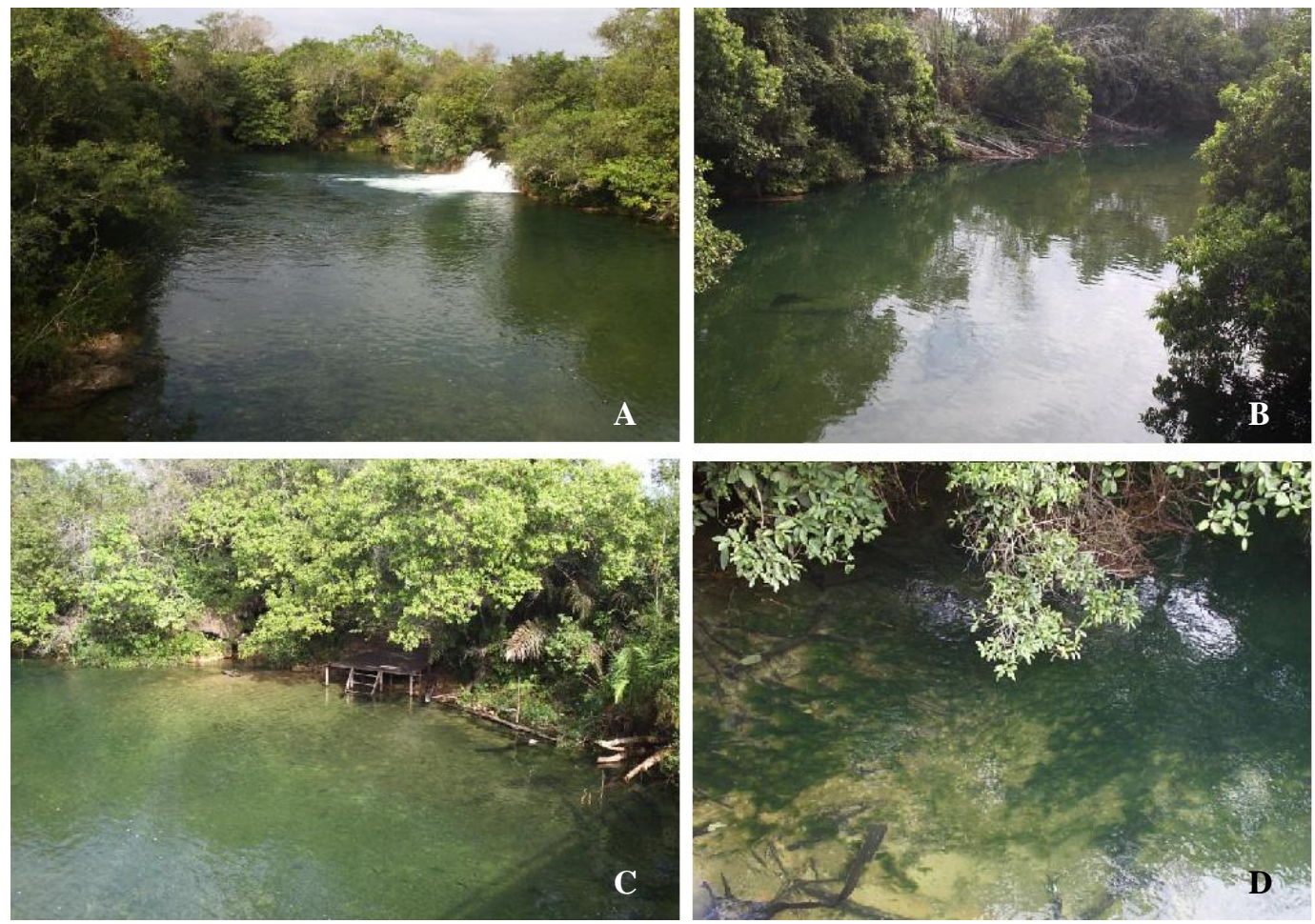

Figura 32- Rio Formoso no Camping Poliana. A) Queda de água. B) Após a queda grande volume de água e pouco fluxo. C) Às margens pequena profundidade e águas límpidas. D) Às margens crescem macroalgas filamentosas.
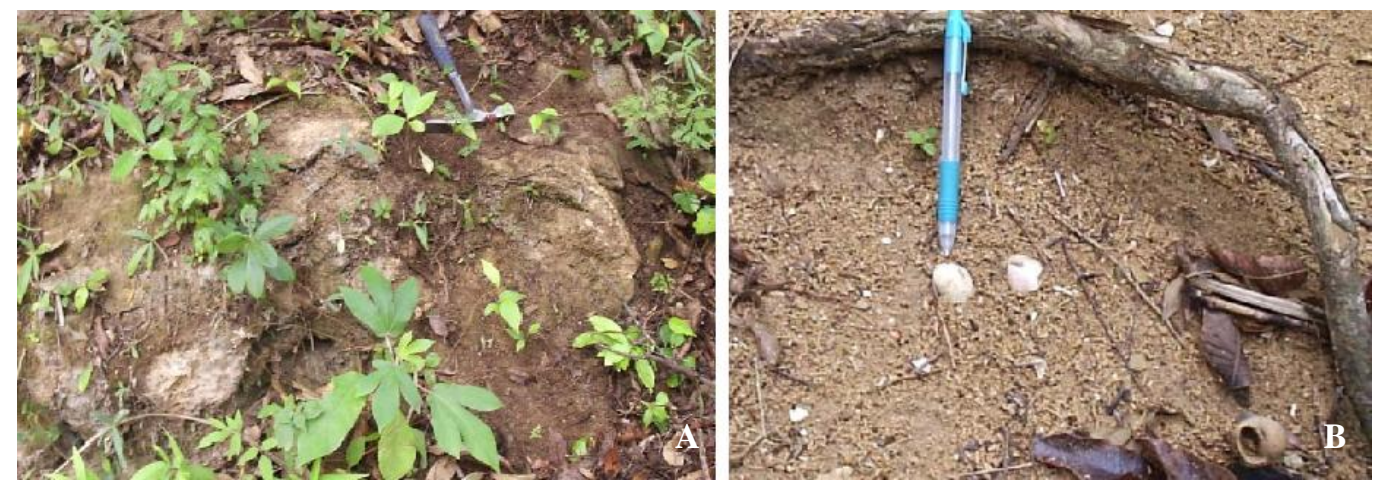

Figura 33 - Antigos depósitos de tufas calcárias às margens do Rio Formoso. A) Tufa calcária semelhante aos de quedas de água. B) Depósito contendo gastrópodes e tubos calcários.

Ponto 18 - Rio Formoso - Ilha do Padre

Neste ponto continua o Rio Formoso, no entanto, ele se divide em dois sistemas diferentes. Em geral a vegetação é bem densa e alta às margens do rio, também há folhas presas em algumas áreas de queda de água, formando tufas fitoclásticas. 
$\mathrm{Na}$ área mais a montante, o rio possui maior profundidade e margens translúcidas com crescimento de macroalgas filamentosas e gastrópodes mortos no fundo (Figura 34). Também há depósito de tubos calcários e nas quedas de água há precipitação de tufas calcárias.

Gastrópodes vivos não foram encontrados, mas neste ponto são encontrados ovos fixos às madeiras das pontes e vegetação próximas às margens (Figura $34 \mathrm{D}$ e E). Eles possuem coloração rosada ou esbranquiçada, provavelmente depois que morrem ou nascem e têm cerca de $0,3 \mathrm{~mm}$ de diâmetro.
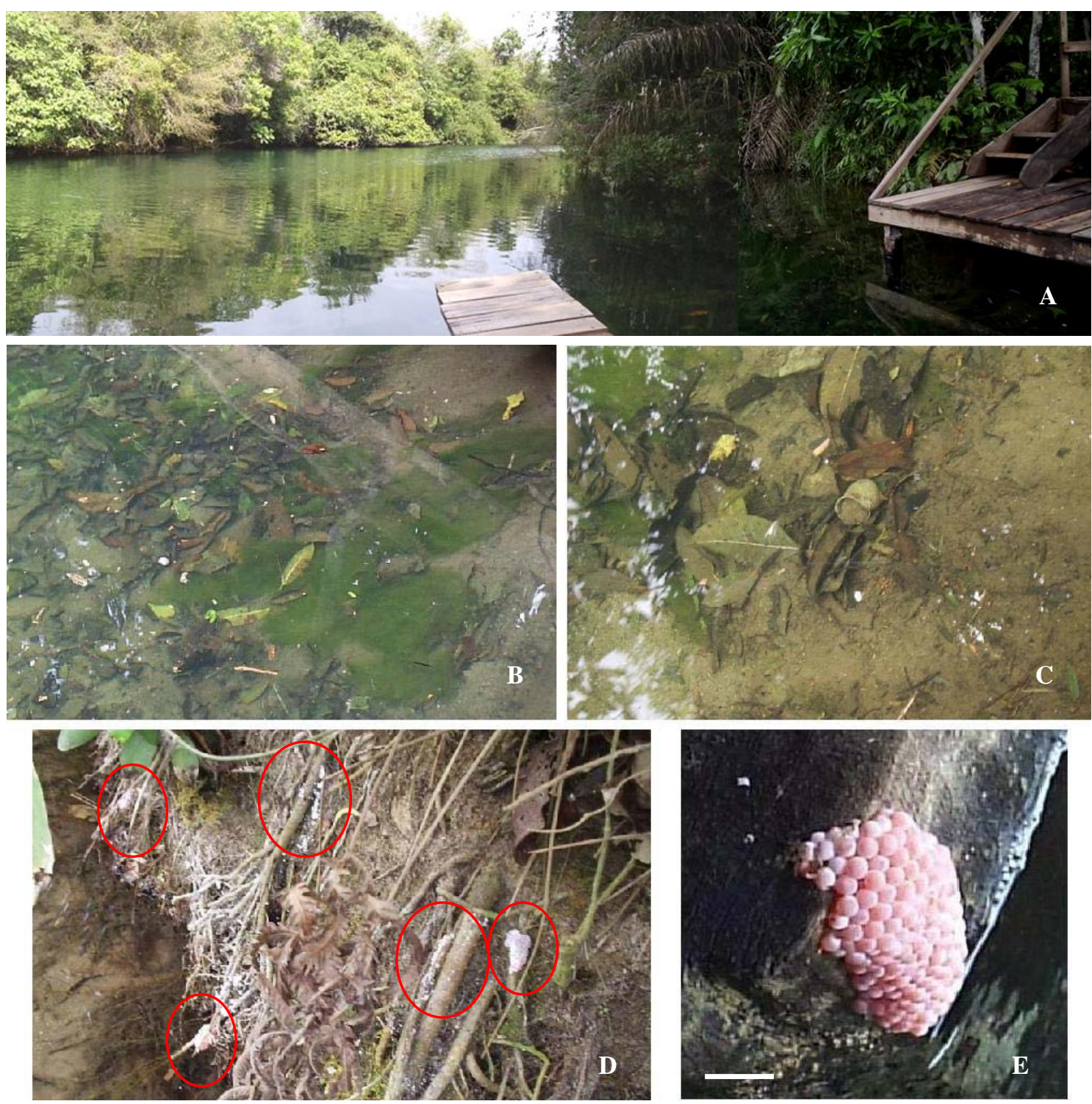

Figura 34 - Detalhes do Rio Formoso na Ilha do Padre A) Notar grande volume de água e pouco fluxo. B) Macroalgas filamentosas. C) Gastrópodes mortos no fundo próximos às margens. D) Ovos de gastrópodes fixos à vegetação à margem do rio destacados em vermelho. E) Ovos de gastrópodes fixos à madeira da ponte, provavelmente Pomacea, pela coloração e tamanho. Escala aproximada de $1 \mathrm{~cm}$. 
No outro sistema o rio tem maior fluxo de água, formando leito menor em alguns pontos (Figura 35). As rochas encontradas são os estromatólitos identificados por Sallun et al. (2007) (Figura 36). Em áreas deste ponto onde se formam pequenos poços submersos, há acúmulo dos tubos carbonáticos, que observados em lupa, podem ser descritos como talos de algas caráceas com incrustações carbonáticas, formando depósito de tufa detrítica. Estes talos podem ter sido transportados em períodos de cheia pelos rios de áreas onde estas algas viveram. Tais áreas provavelmente possuem alguma ligação com o leito do rio, apenas nos períodos de cheia. Também ocorrem áreas com pequenos remansos.

Nestes locais não ocorrem macroalgas filamentosas, nem algas caráceas. São vistos apenas musgos em áreas com pequena lâmina de água. Alguns gastrópodes mortos são encontrados nestas áreas antes das quedas de água, da mesma forma que os tubos.

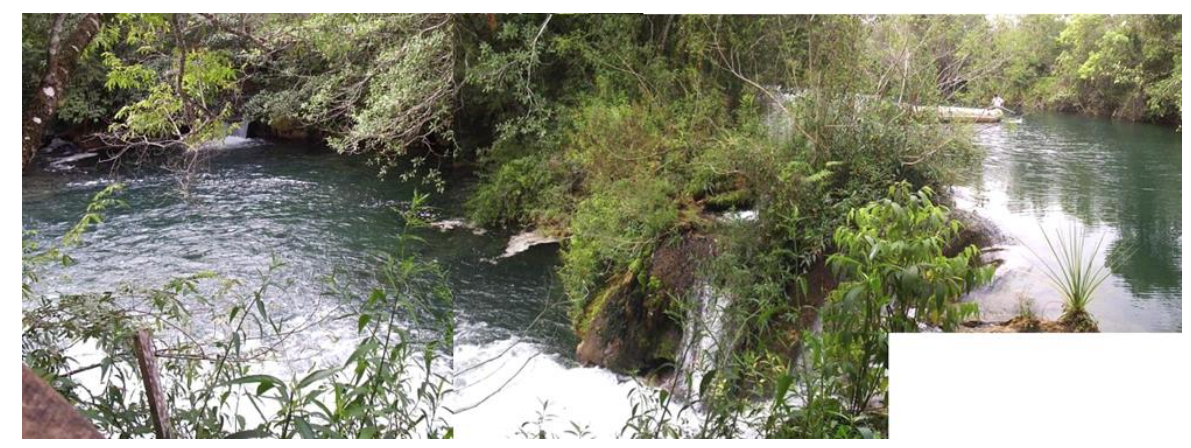

Figura 35 - Rio Formoso. Sistema com maior fluxo de água.

Ponto 19 - Rio Formozinho

O Ponto 19 exibe micritos consolidados encontrados às margens do Rio Formozinho, com a presença de gastrópodes dos gêneros Biomphalaria e Pomacea (Figura 37). Estes micritos provavelmente foram consolidados por processos intempéricos, conforme visto no afloramento da Mineração Calcário Xaraés, Ponto 01, evidenciados por uma porção mais clara do micrito ao redor de uma porção de carbonato cinza mais escuro (Figura 37). É possível que o micrito tenha sido dissolvido da superfície externa, com reprecipitação do carbonato no seu interior, preservando os gastrópodes.

Também às margens desse Rio onde há solos, ocorrem gastrópodes do gênero Pomacea (Figura 38). Possivelmente estes gastrópodes são mais recentes que os micritos da área, pois mostram coloração e não há aspectos de dissolução nas conchas. 
Tufas calcárias do tipo fitohermal ocorrem na área, mas estão caídos no leito do rio, e não foram encontradas nas margens.
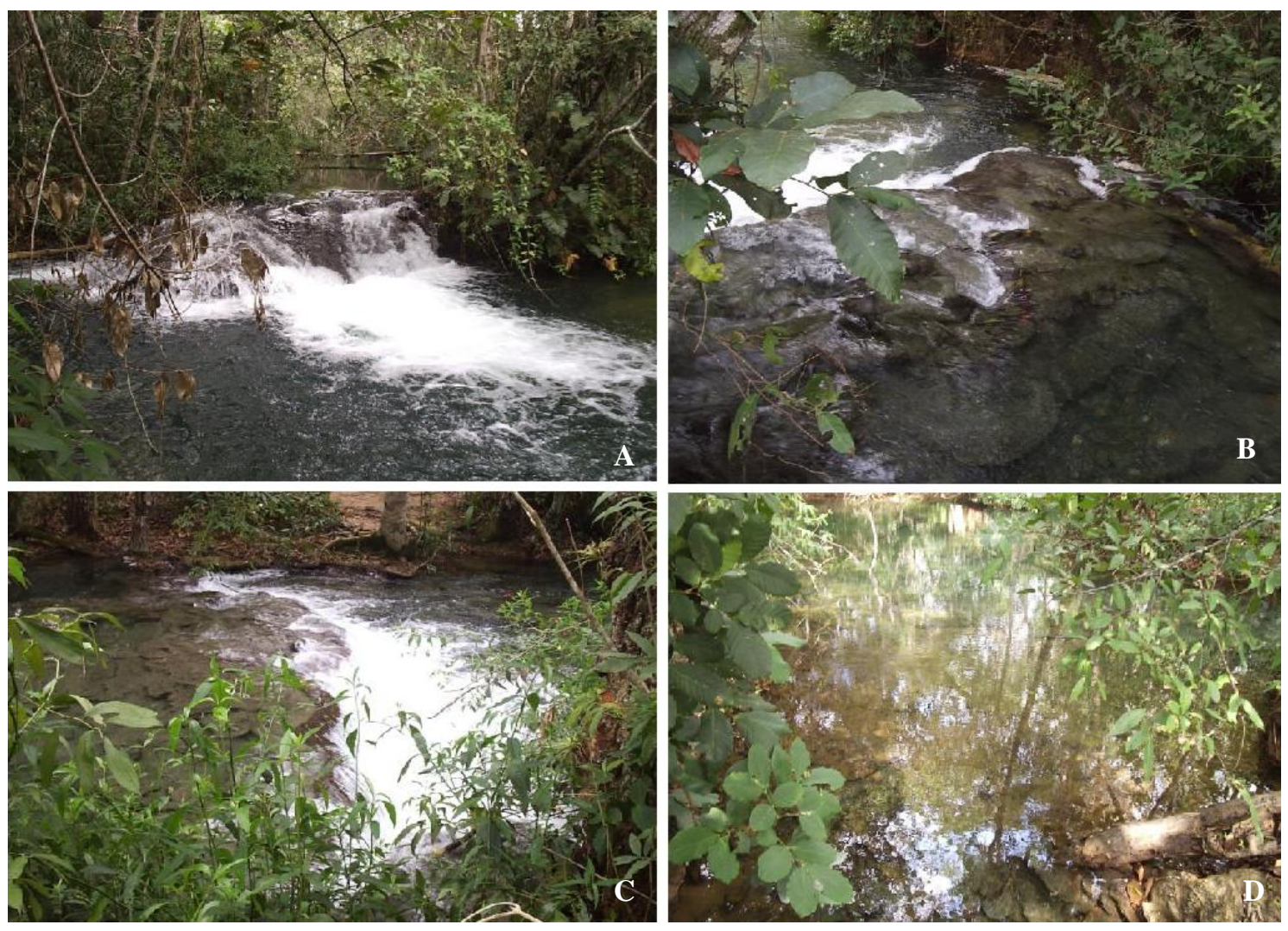

Figura 36 - Rio Formoso. A, B e C) Área de maior fluxo do Rio Formoso. D) Área de remanso. Ocorrência de estromatólitos recentes no leito do rio.

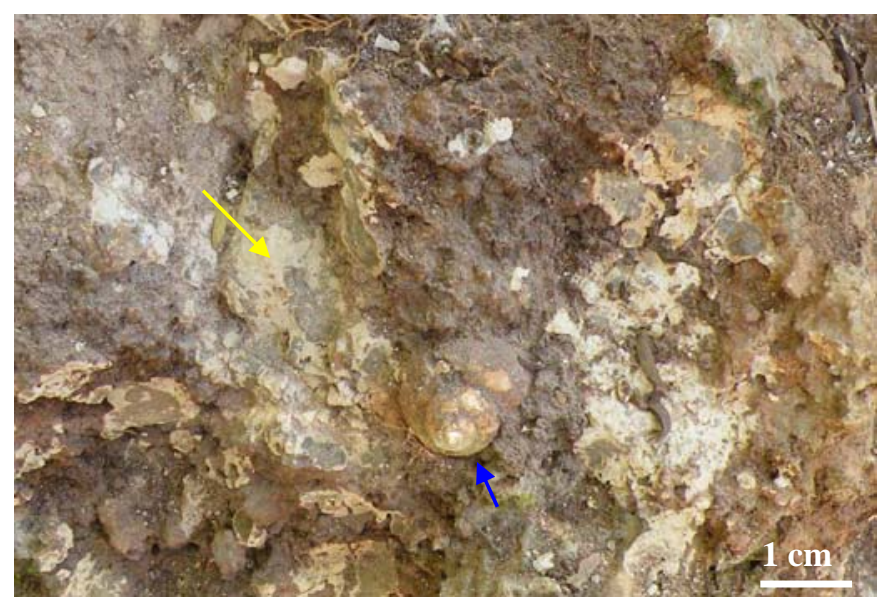

Figura 37 - Micrito consolidado encontrado as margens do Rio Formozinho. Gastrópode do gênero Pomacea indicado pela seta azul e alteração do carbonato indicada pela seta amarela. 

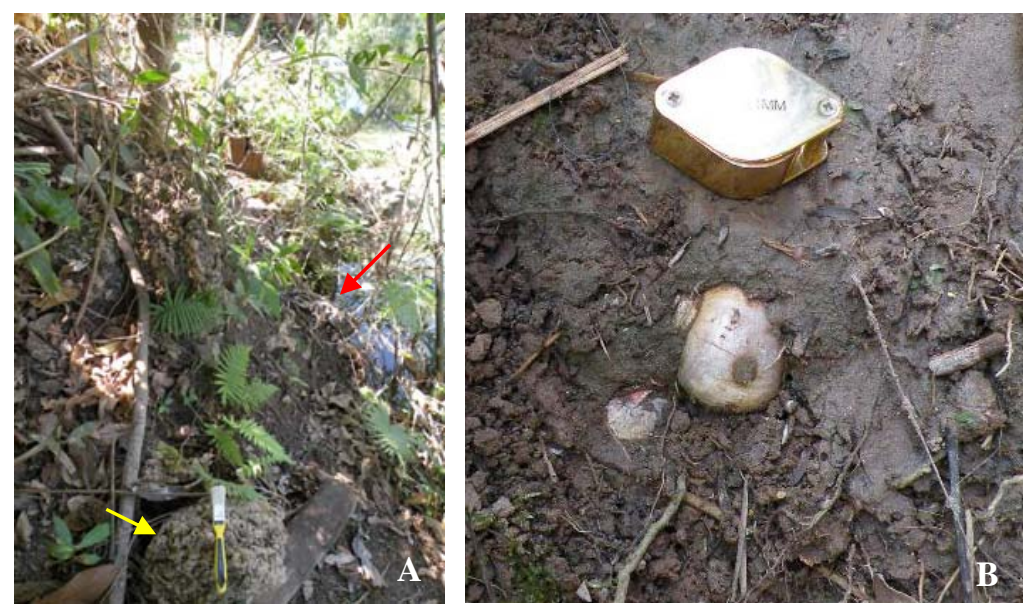

Figura 38 - Tufas calcárias nas margens do Rio Formozinho. A) Localização do micrito consolidado, seta amarela, e do gastrópode, seta vermelha, no solo representado em B) Gastrópodes do gênero Pomacea em solo às margens do Rio Formozinho.

Ponto 21 - Rio Formoso - Praia da Figueira

O ponto 21 se refere a uma antiga mineração de calcário, segundo informações de pessoas do local, semelhante à Mineração Calcário Xaraés, hoje transformado em área de lazer.

Na área da antiga lavra foi construída uma praia artificial (Figura 39 A) com água desviada do Rio Formoso. O sedimento de carbonato não está presente no leito da praia, causado por preenchimento de areia para evitar a presença de detritos originados dos carbonatos, o que deixaria as águas turvas, reduzindo o interesse dos turistas.

O Rio Formoso, no mesmo local, exibe águas de turbidez pequena a nula e baixa turbulência (Figura 39 B), correndo sobre sedimentos carbonáticos no leito do rio. Depósitos de micritos desenvolveram-se às margens do rio com presença de gastrópodes. A vegetação ao redor é mais densa e de grande porte, dominada por angiospermas.

Na vegetação às margens do rio, foram observados diversos ovos de gastrópodes (Figura 39 C e D) do gênero Pomacea, assim como conchas depositadas no leito do rio. Também ocorrem diversos peixes de aproximadamente $5 \mathrm{~cm}$ vivendo próximo às margens do rio. 

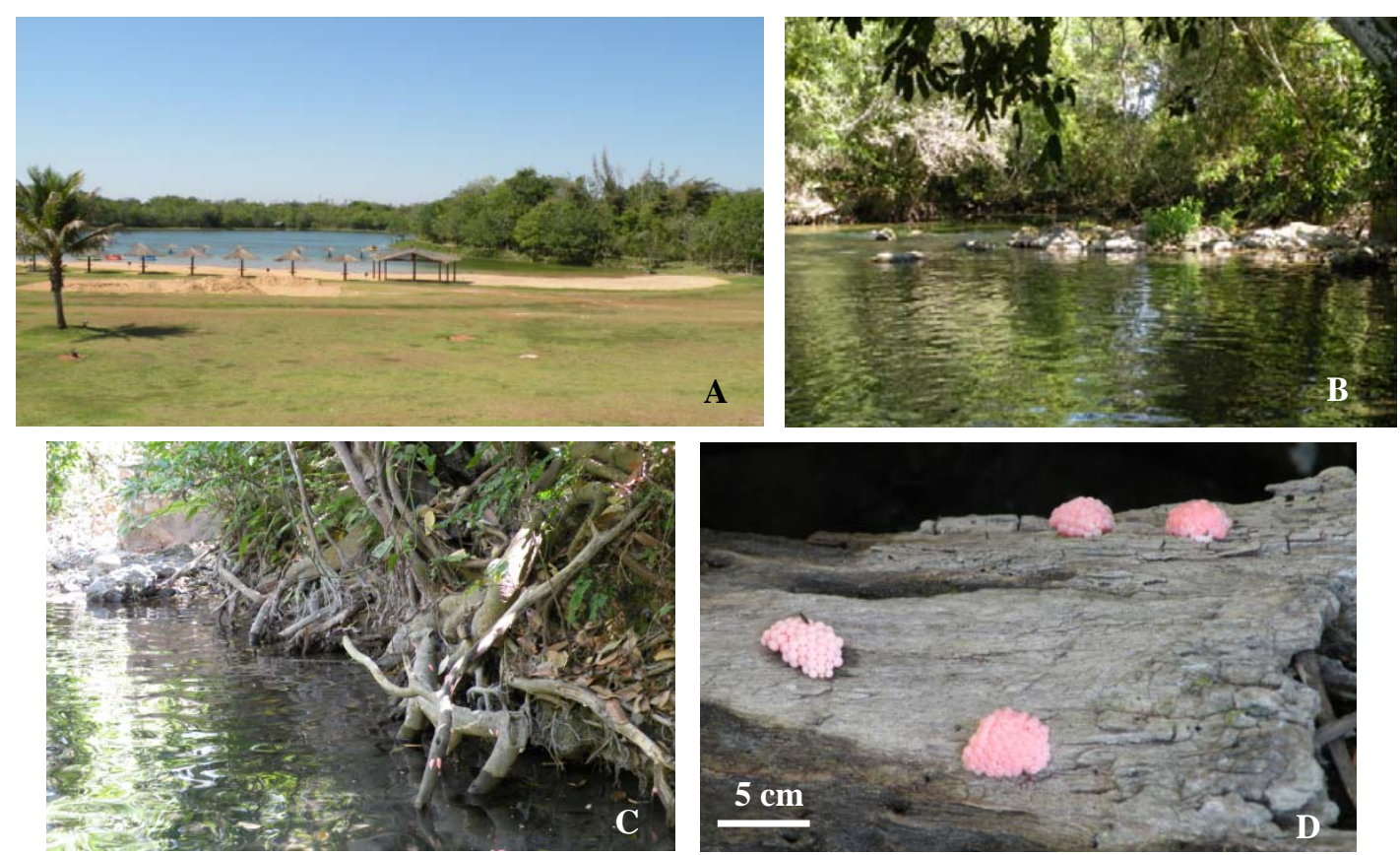

Figura 39 - Rio Formoso. A) Praia da Figueira. B) Rio Formoso C) Margem com diversas oviposições do gênero Pomacea. D) Detalhe dos ovos de Pomacea.

Ponto 23 - Rio do Prata

Nesta área ocorrem micritos inconsolidados às margens do Rio do Prata com a presença de gastrópodes. O rio entalha estes micritos inconsolidados, pois seu leito encontrase abaixo do nível de exposição deste carbonato, que ocorrem até cerca de $4 \mathrm{~m}$ acima do leito do rio. Acima destes $4 \mathrm{~m}$ há uma planície de grande extensão.

É um rio com grande fluxo de água, mas de pouca turbulência (Figura 40 A), mais profundo ao meio do leito. Também ocorrem tufas calcárias de cachoeiras (Figura 40). Não foram observados ovos ou conchas no leito do rio por ser de difícil acesso. 

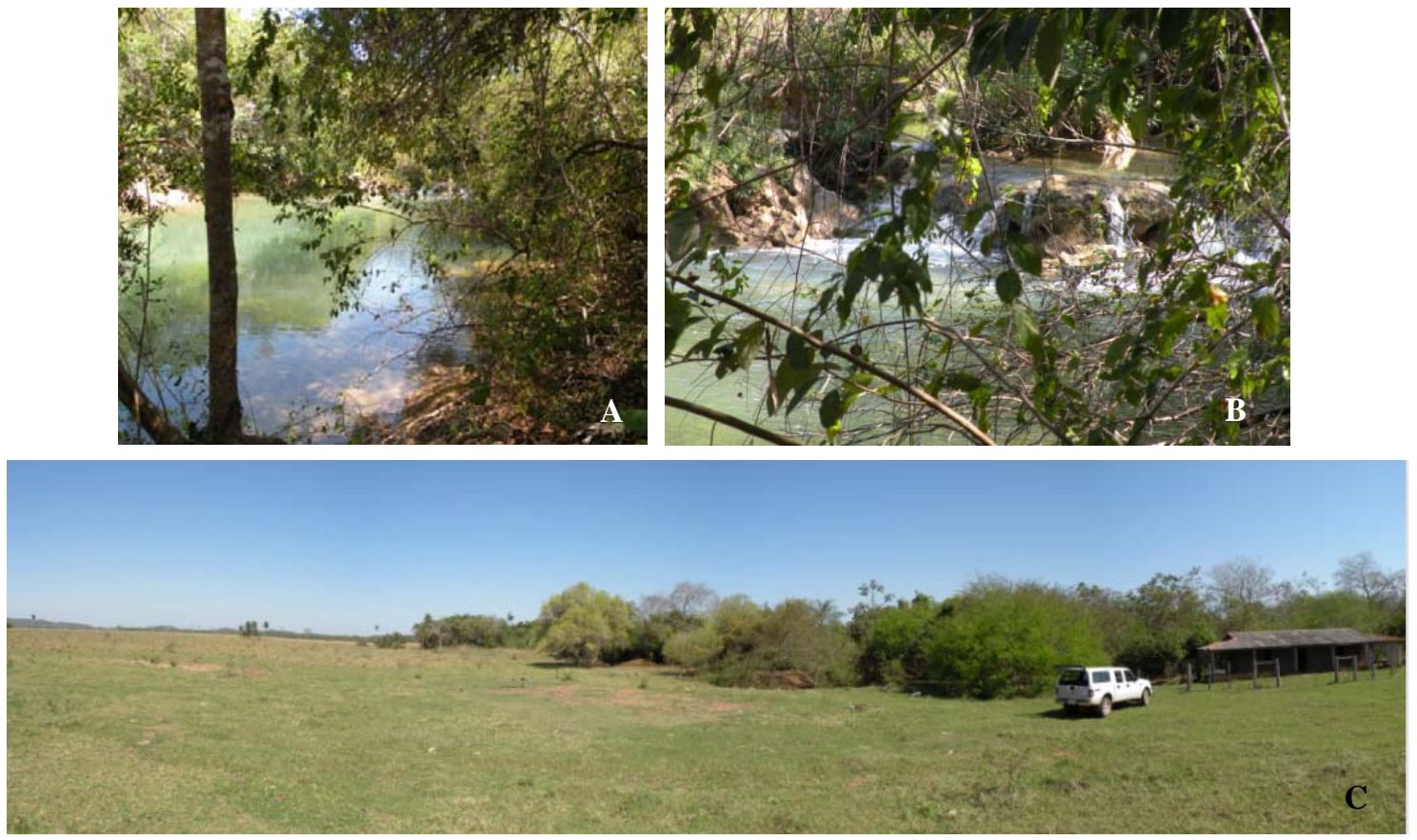

Figura 40 - A) Leito do rio com baixa turbulência. B) Tufas de cachoeira localizadas ao fundo da imagem A. C) Panorâmica de parte da planície acima do leito do Rio do Prata. O rio encontra-se atrás da casa entre a vegetação.

Ponto 28 - Rio Mimoso - Estrada Bonito-Bodoquena

A estrada Bonito-Bodoquena corta o Rio Mimoso que foi represado acumulando sedimentos e matéria orgânica acima das cachoeiras (Figura 41). O represamento foi feito para abastecimento de água, modificando o curso do rio, provavelmente cessando a deposição sobre os tufas das cachoeiras na área (Figura 42).
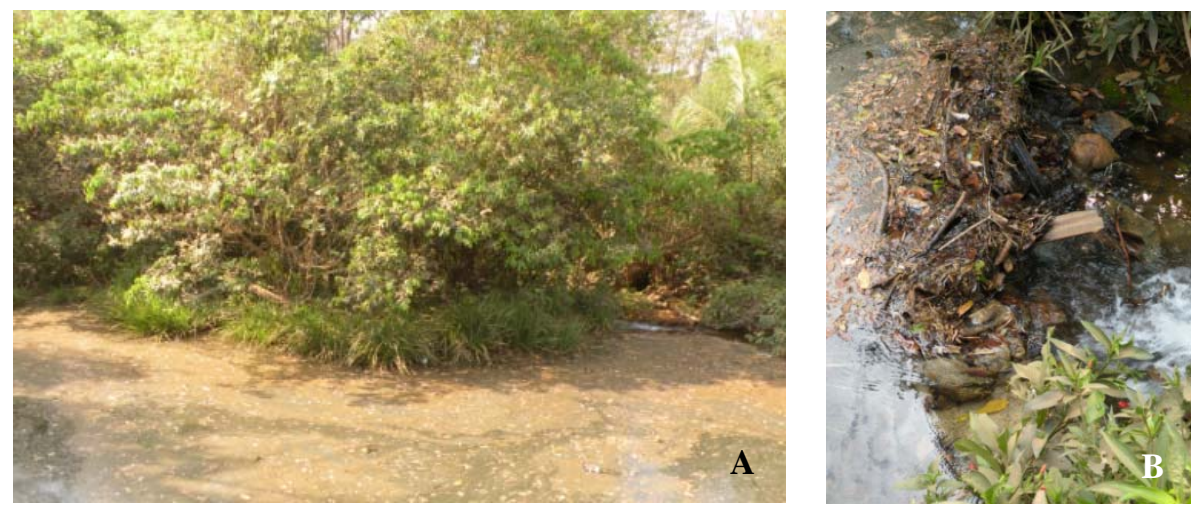

Figura 41 - Rio Mimoso represado neste ponto. A) Acúmulo de sedimentos e matéria orgânica causado pelo represamento. B) Local da barragem. 
O represamento reduziu o volume de água abaixo da represa e expôs uma área de carbonato com conchas de gastrópodes (Figura 43). Nesta exposição, em perfil, são visíveis gastrópodes na porção superior constituída de solo e em direção a base nota-se a presença de gastrópodes em um nível de maiores concentrações de conchas (Figura 43B). Próximo à base há um nível com seixos. Não foi possível alcançar este local para observar se ocorrem outros moluscos além dos gastrópodes. A vegetação do local também é densa, com gramíneas nas margens do rio. Não foi visto nenhum vestígio que indicasse a presença de gastrópodes viventes na área.
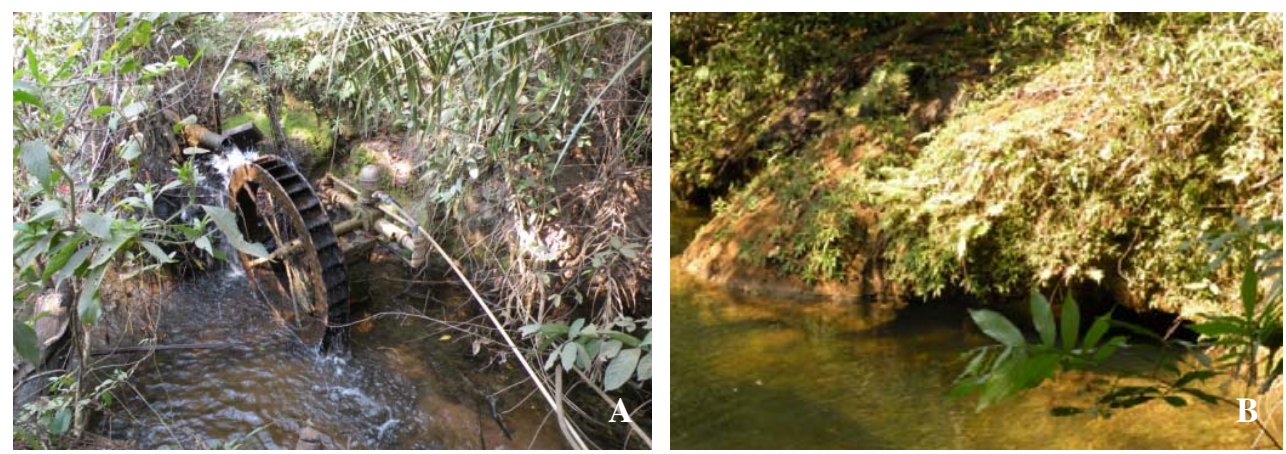

Figura 42 - Rio Mimoso. A) “Equipamento” para retirada de água do rio. B) Tufa calcária de cachoeira provavelmente extinta pelo represamento do rio.
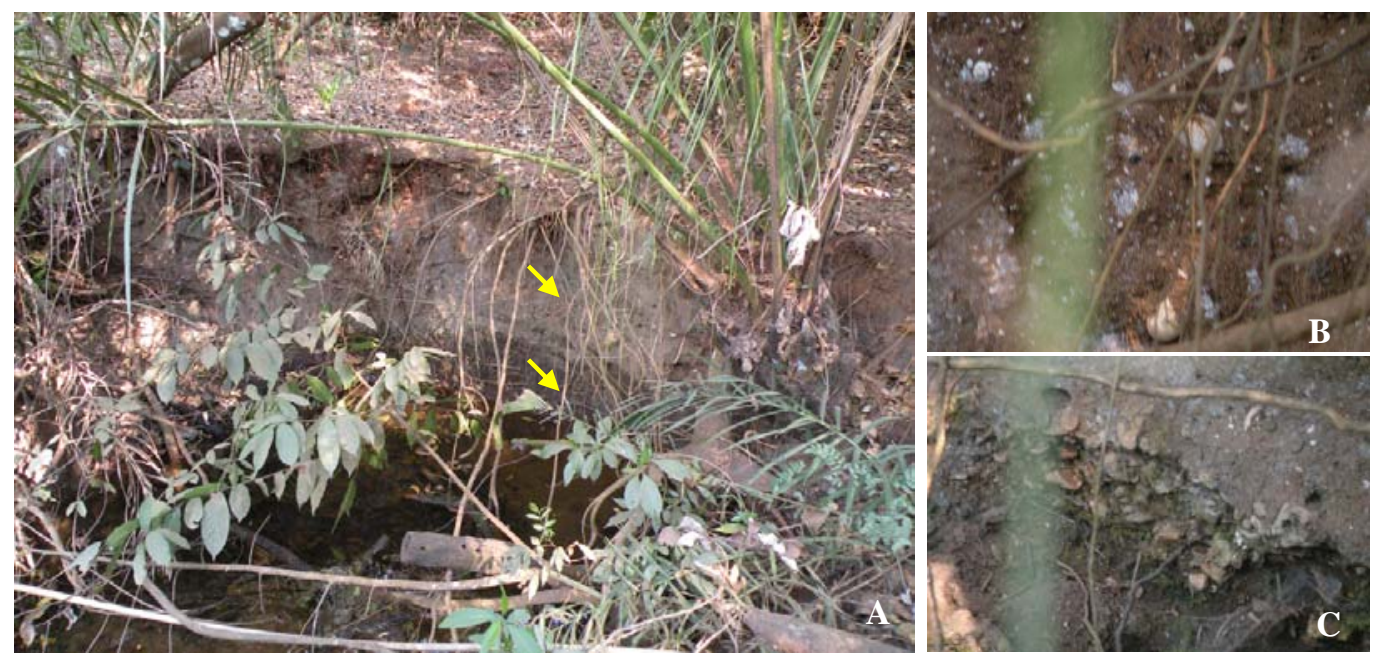

Figura 43 - A) Área exposta de sedimentos próxima a coleta de água. A seta superior indica localização da figura 43 B, a inferior a localização da figura 43 C, logo abaixo, a água está presente. B) Conchas de moluscos na área exposta. C) Seixos expostos na base do afloramento. Imagem sem escala, não foi possível alcançar o local. 


\section{Ponto 29 - Córrego Olaria}

Neste ponto ocorrem tufas de cachoeira, além de micritos às margens do rio, com a presença de gastrópodes dos gêneros Biomphalaria, Pomacea e possivelmente Idiopyrgus. O rio possui uma porção represada e uma com pequenas quedas. Possui baixa correnteza com vegetação abundante às margens, tanto com gramíneas quanto angiospermas (Figura 44).
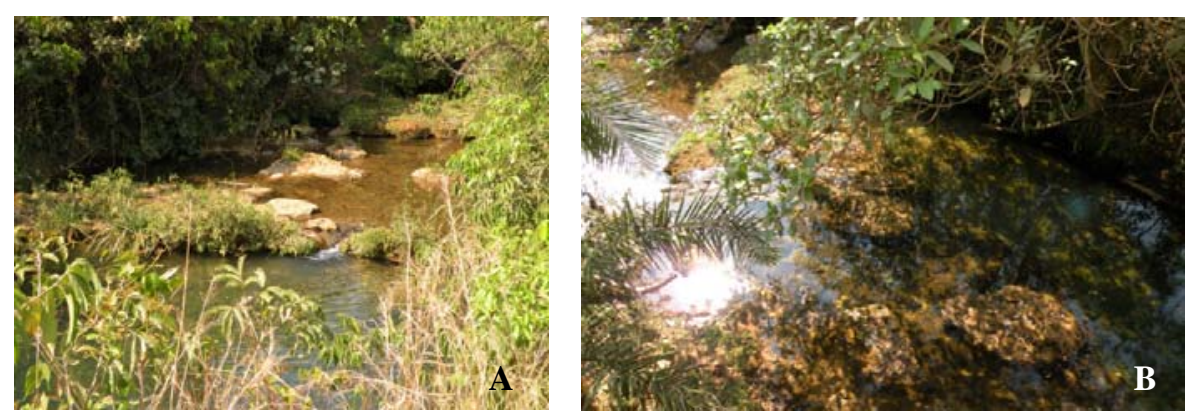

Figura 44 - Córrego da Olaria. A) Porção represada do córrego por tufas de barragem. B) Porção com tufas de cachoeira.

Ponto 30 - Córrego Pitangueiras

Novamente o leito do rio entalha os micritos consolidados presentes às suas margens no Córrego Pitangueiras (Figura 45). Ocorre o crescimento de vegetação sobre os micritos e em algumas áreas as tufas fitohermais ocorrem junto com os micritos (Figura 45 B). Este tipo de tufa calcária é característica por apresentar laminações (Ford \& Pedley, 1996). As tufas de cachoeira também aparecem ao longo do leito do rio (Figura 45 A). Nesta área a vegetação não é tão densa e as gramíneas são menos abundantes.

Em uma porção mais a montante do rio, com maior desnível em relação ao rio, há um afloramento de micritos detríticos pouco espessos sobre uma argila vermelha (Figura 46). Gastrópodes, talos de algas e briófitas são abundantes (Figura 46 B).

Na porção a jusante do rio o leito entalha a argila, sem ocorrência de micritos (Figura 47), como em porção a montante (Figura 45 A). 

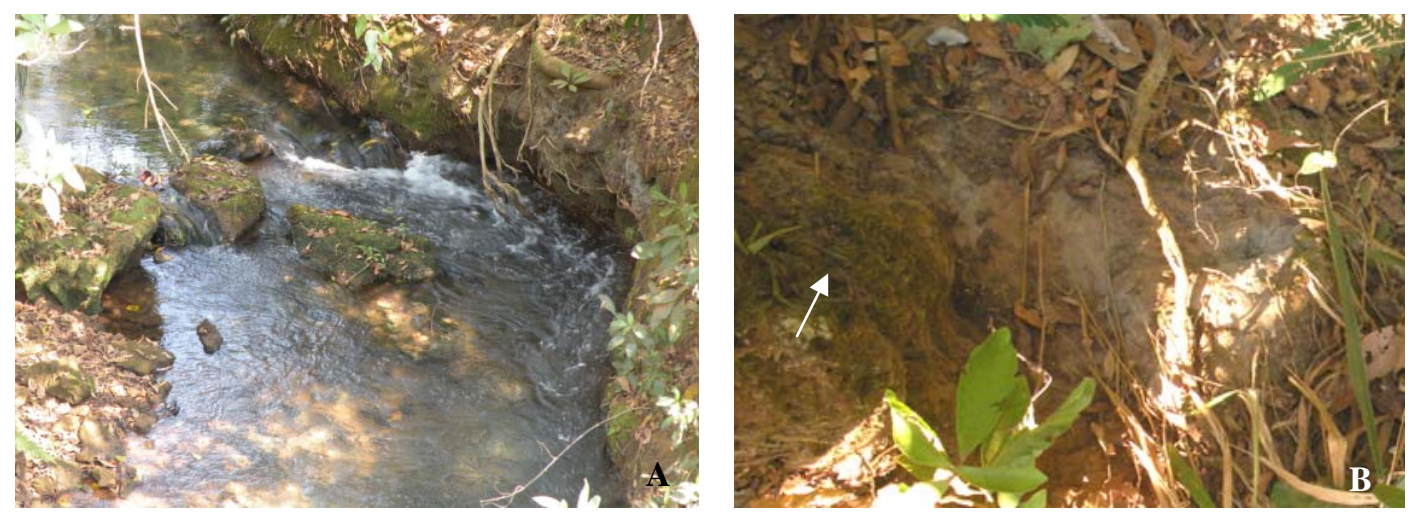

Figura 45 - Córrego Pitangueiras. A) Leito do rio entalhando o depósito de micritos e tufas no leito. B) Micritos expostos às margens do rio, a esquerda tufa fitohermal recoberta por musgos, indicada pela seta, e a direita micrito com conchas de moluscos.
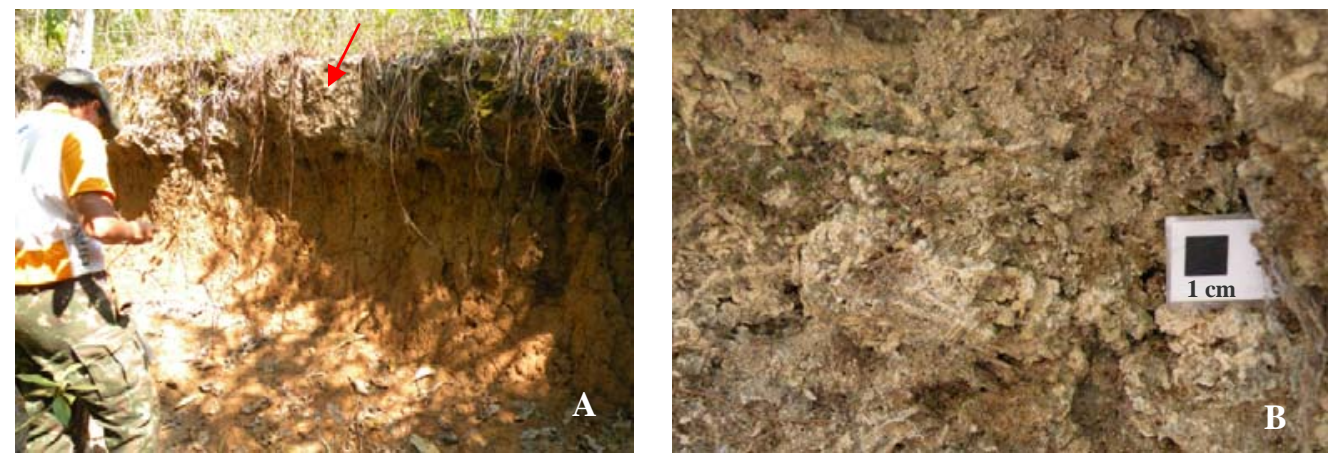

Figura 46 - Depósitos próximo ao Córrego Pitangueiras. A) Afloramento de micritos detríticos sobre argila de cor vermelha a montante do rio. Seta vermelha indica posição do micrito detrítico. B) Micrito detrítico.

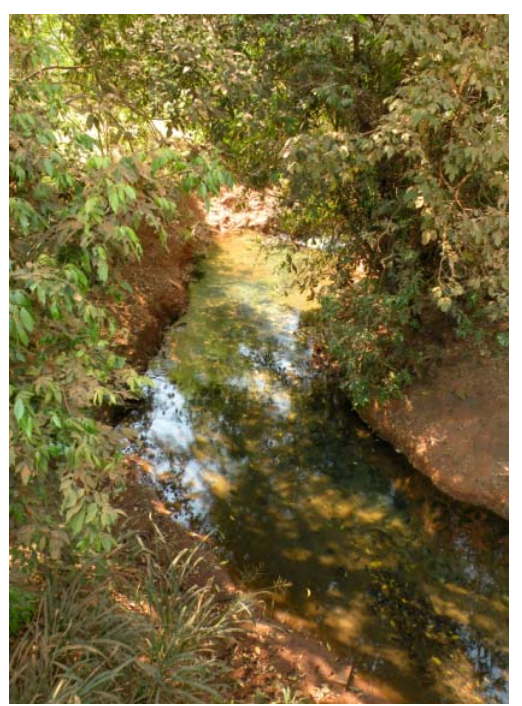

Figura 47 - Córrego Pitangueiras. Porção a jusante do ponto 30 marcado com GPS. Notar que o rio entalha a argila e não carbonatos. 
Nascente do Rio Sucuri

A nascente do Rio Sucuri está localizada próxima a Mineração Calcário Xaraés e a Praia da Figueira (Figura 48A). A visita ao local foi feita no mês de março, período de cheia na região, acompanhada de guia e turistas, não sendo permitida a coleta de amostras. $\mathrm{O}$ trecho percorrido possui cerca de $2 \mathrm{~km}$, sendo 0,2 km de caminhada até a nascente (Figura 49 A e B) e 1,8 km de flutuação no rio.

A água que abastece o Rio Sucuri é de origem subterrânea, formando um remanso de águas com turbidez nula com a presença de algas, macrófitas aquáticas e gastrópodes. A vegetação em torno da nascente é densa e muitos fragmentos de vegetais são encontrados na água (Figura 49).

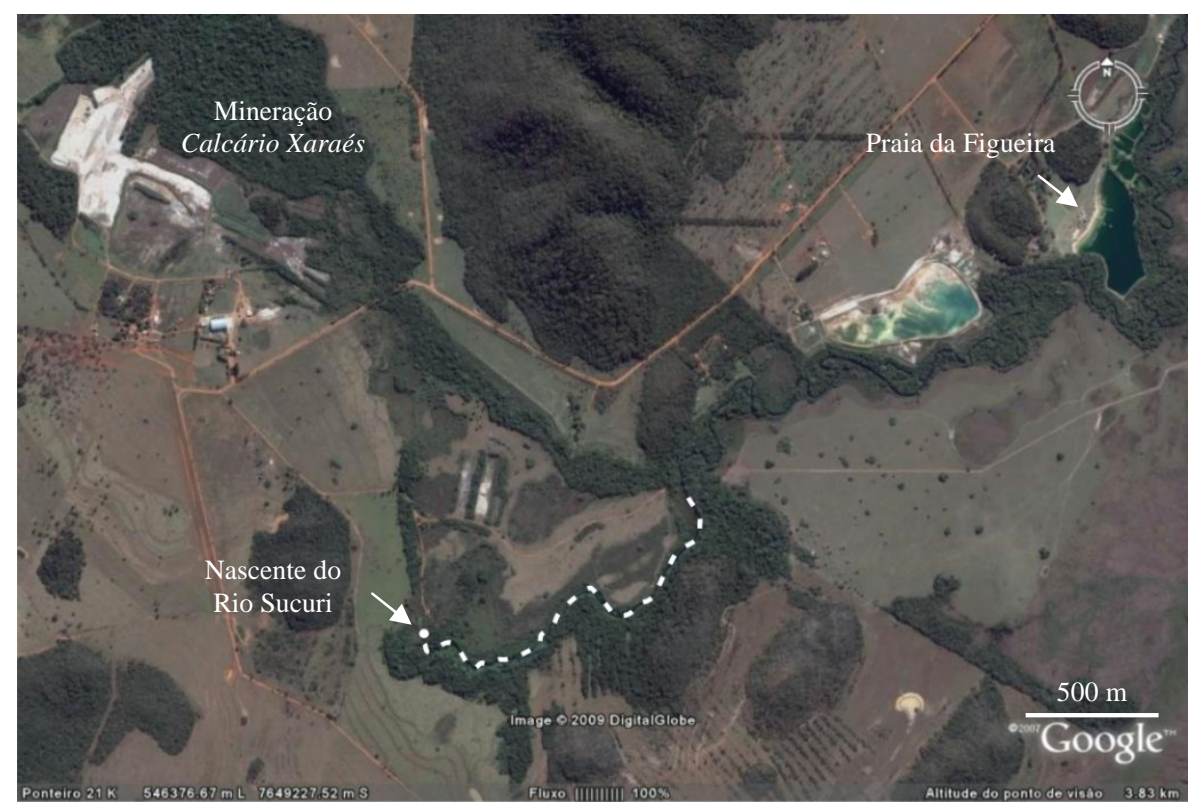

Figura 48 - Localização da nascente do Rio Sucuri. A linha pontilhada se refere ao trecho percorrido. Fonte: Google, 2009.

Várias nascentes fornecem água para o Rio Sucuri que se torna profundo e largo, em alguns pontos com $5 \mathrm{~m}$ de profundidade. Muitas conchas de gastrópodes do gênero Pomacea são vistas no leito do rio, acumulando-se em determinadas áreas devido à correnteza. Os fragmentos das conchas também se acumulam, formando um sedimento branco (Figura 49 C).

Há muita vegetação subaquática, incluindo grandes populações de algas caráceas (Figura 49 E e F). Apesar de ser um rio com grande volume de água, a correnteza é fraca, permitindo que estas algas sobrevivam. 

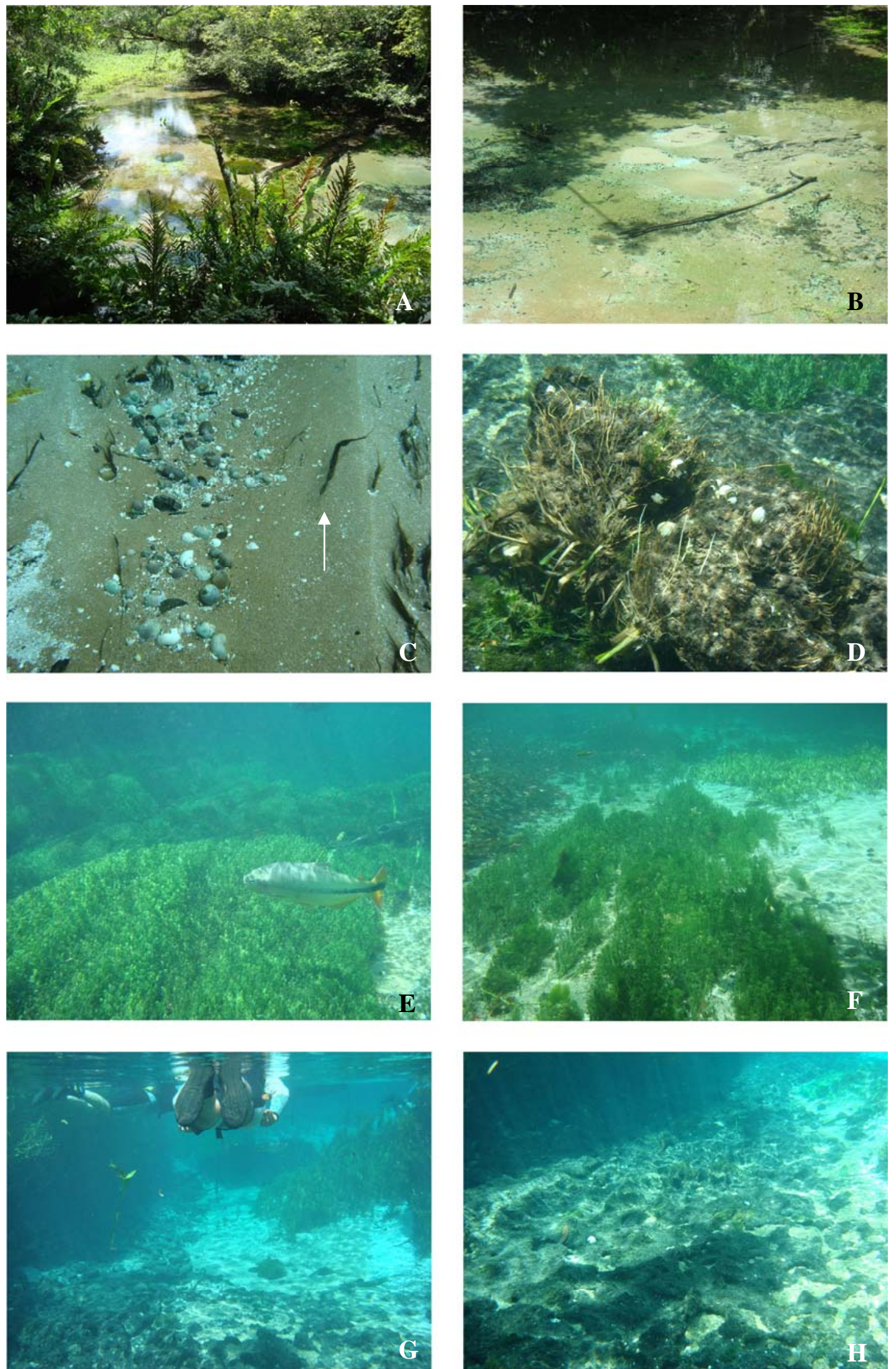

Figura 49 - Rio Sucuri, Bonito, MS. A) Nascente do Rio Sucuri. B) Detalhe da água aflorando. C) Acúmulo de conchas no leito do rio, a seta indica o sentido da corrente. D) Porção de sedimento solto com vegetação e muitas conchas de gastrópodes. E, F) População de algas caráceas no Rio Sucuri. G) Micritos endurecidos no leito do rio. $\mathrm{H}$ ) Detalhe dos micritos no leito do rio. 
O leito do rio corre sobre os micritos, com aspecto endurecido, como visto em outros depósitos (Figura $49 \mathrm{G}$ e H). Fragmentos de micritos com muitas conchas são encontrados fixos a vegetação (Figura 49 D), naqueles mais endurecidos também é possível visualizar as conchas.

Estes micritos erodidos pelo Rio Sucuri são extensão dos depósitos observados na Mineração Calcário Xaraés e os que foram explorados na Praia da Figueira, demonstrando grande extensão dos depósitos de micritos na área. Não ocorre a formação de tufas ao longo do trecho percorrido do rio.

\subsubsection{Depósitos do Pantanal}

Calcários do Pantanal do Miranda (Boggiani \& Coimbra, 1995)

Os calcários do Pantanal do Miranda, encontradas ao longo da Estrada Parque Pantanal Sul em formas de lentes, estão associados à presença de Pomacea ou Marisa, gêneros de gastrópodes atuais encontrados incrustados nestas rochas, inferindo uma idade recente ao depósito. Tais gêneros ainda são encontrados vivos na área próxima a estes carbonatos. O gênero Marisa não foi encontrado nos depósitos da região da Serra da Bodoquena.

Segundo Thomas \& Daldorph (1991) a introdução artificial de indivíduos da família Amphularidae, principalmente Pomacea e Marisa, pode controlar a população de planorbídeos, que inclui o gênero Biomphalaria. É provável que isto ocorra naturalmente controlando a população de Biomphalaria, ou até impedir que ela se estabeleça, motivo que pode justificar sua baixa freqüência ou até ausência, e não modificação do ambiente em que foram depositados.

Ponto 32

A primeira lente visitada na Estrada Parque Pantanal Sul, sentido Miranda-Corumbá do lado esquerdo da via, apresenta-se com aspecto bem intemperizado, variando entre uma coloração bege clara ao cinza. Trata-se de uma rocha bem compacta, em uma frente erosiva 
de, aproximadamente, $1 \mathrm{~m}$ de altura, de um depósito que se projeta acima dos demais terrenos (Figura 50), a erosão ocorre nos períodos de cheia do Pantanal, quando a água do Rio Miranda atinge este depósito (Boggiani \& Coimbra, 1995). A rocha com cavidades erosivas exibe muitas conchas, principalmente do gênero Pomacea (Figura 50 B). O gênero Pomacea é vivente na área, através de conchas de indivíduos encontrados próximo ao depósito. A idade obtida para este depósito pelo método ${ }^{14} \mathrm{C}$ é de $3.910 \pm 110$ anos A.P. (Boggiani et al., 1998).

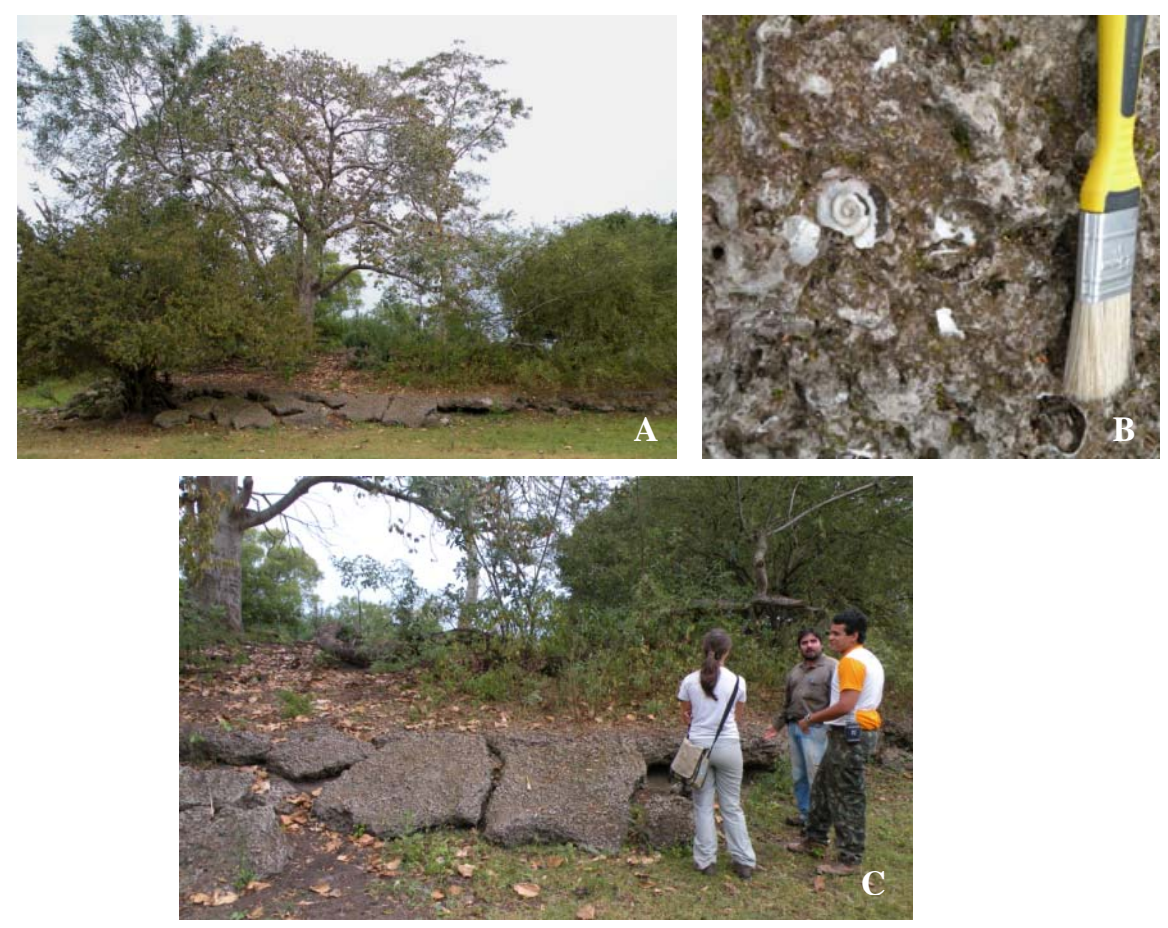

Figura 50 - Lente do Pantanal do Miranda. A) Visão geral do depósito. B) Detalhe da rocha com conchas do gênero Pomacea. C) Detalhe do afloramento.

Ponto 38

Neste outro ponto mais adiante da Estrada Parque Pantanal Sul, o depósito do tipo lente é aparentemente menos intemperizado (Figura 51), mas apresenta a mesma coloração interna e consistência, no entanto, a rocha é compacta.

Aqui as conchas de Pomacea não ocorrem no calcário, apesar de serem encontradas conchas de indivíduos atuais na mesma área. Ocorre nesta lente apenas o gênero Marisa (Figura 52). 
Estes gêneros de gastrópodes ocupam o mesmo tipo de habitat, sendo possíveis competidores, o que explicaria a não coexistência deles, tanto nos carbonatos, quanto no ambiente atual. Outra possibilidade é a intolerância a determinadas variáveis ambientais desconhecidas, que poderiam restringir a existência de apenas um dos gêneros.
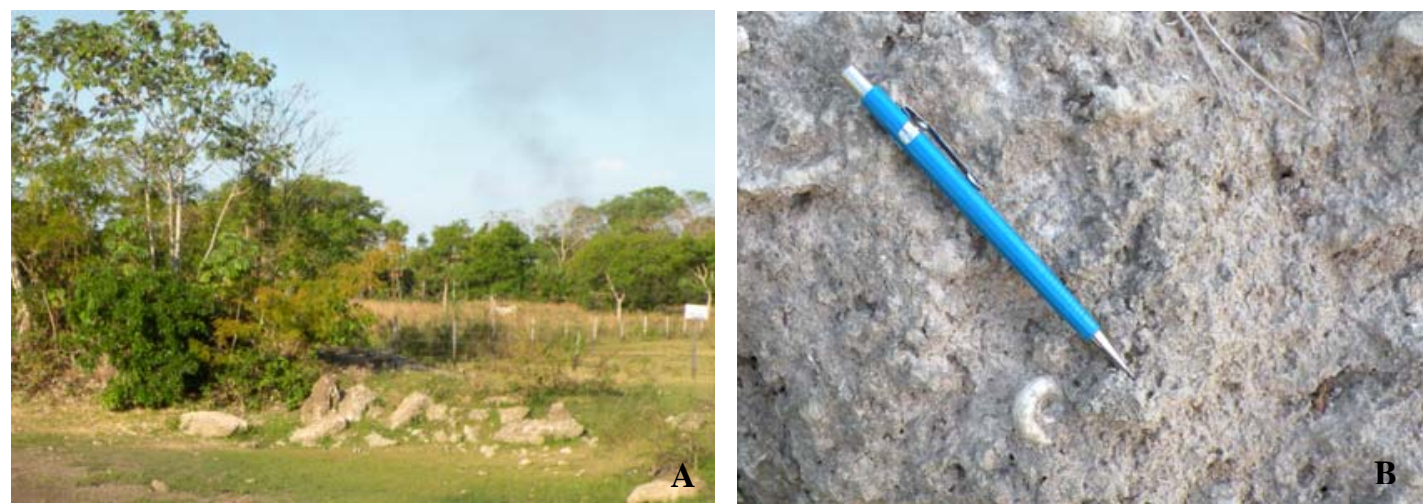

Figura 51 - Lente do Pantanal do Miranda. A) Vista do afloramento da Lente. B) Detalhe da rocha com gastrópode.

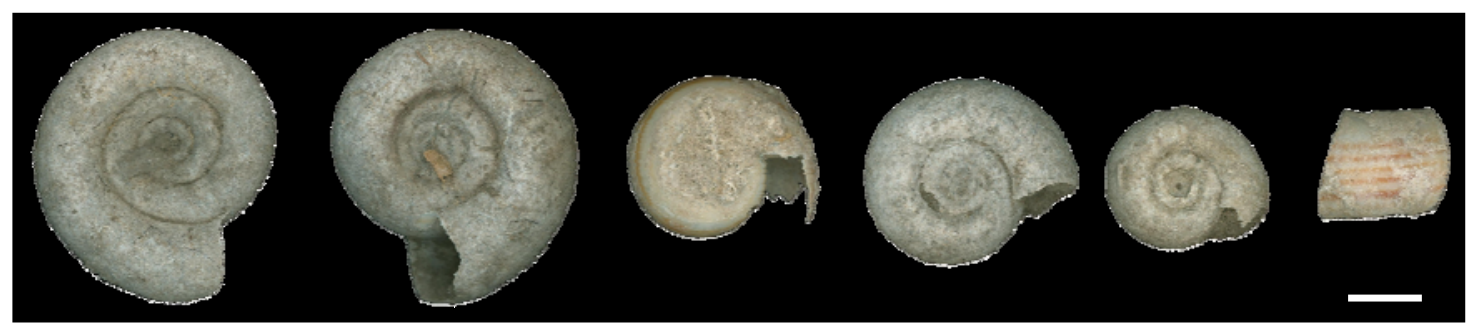

Figura 52 - Exemplares de gastrópode do gênero Marisa encontrados em uma das Lentes Calcárias do Pantanal do Miranda. As duas primeiras conchas representam o mesmo indivíduo.

\subsubsection{Depósito de Corumbá}

Ponto 34 - Margens do Rio Paraguai - Corumbá

Almeida (1945) descreveu conglomerados com cimento calcário apresentando raramente material fóssil, aqui classificados como diamictitos com cimento carbonático (Figura 53), possui diversos intraclastos e clastos de tamanhos e origem variados com prováveis fragmentos de moluscos em algumas porções (Figura 53 C e D). 
Estes fragmentos foram interpretados como fragmentos de conchas de moluscos por não apresentarem outro tipo de deposição orgânica associada, espessura compatível com as conchas, não serem completamente retilíneos, apresentarem bordas lineares e possuírem composição carbonática. Estão imersos em matriz de intraclasto de provável micrito consolidado, da mesma forma que foi observada nos micritos da região da Serra da Bodoquena. O afloramento encontra-se em frente ao posto de abastecimento de embarcações no porto de Corumbá e possui diversos blocos caídos do afloramento.
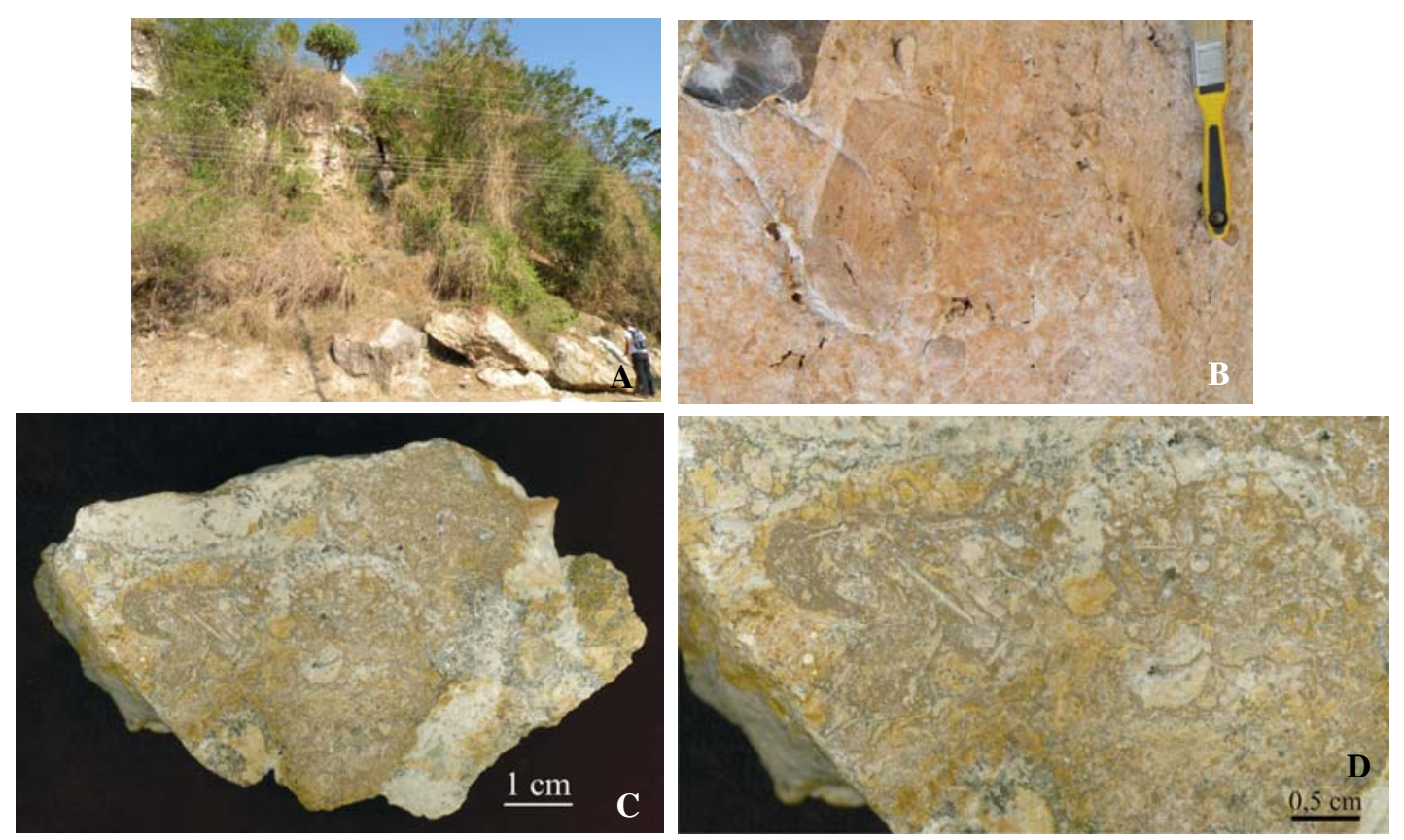

Figura 53 - A) Afloramento em frente ao posto de abastecimento de barcos no porto de Corumbá-MS. B) Detalhe do depósito. C) Amostra com prováveis fragmentos de moluscos em um intraclasto. D) Detalhe da porção com prováveis fragmentos de moluscos.

\subsection{Considerações}

A presença de gastrópodes vivos durante a época de estudo de campo não foi evidente, apenas ovos em áreas de maior volume de água no Rio Formoso. Os indivíduos observados estavam mortos nas margens, no fundo dos rios próximos às margens, nas proximidades das quedas de água em áreas com menor fluxo e em locais de inundação, além daqueles presentes nos depósitos carbonáticos.

Os gastrópodes estão associados à presença de algas subaquáticas, as quais são fontes de seu alimento. As algas ocorrem próximas às margens dos rios e em locais de pouca 
profundidade, o que pode estar associado ao grau de turbidez das águas, que permite luminosidade adequada para o processo de fotossíntese desses vegetais.

Diante do exposto a presença de gastrópodes nos depósitos carbonáticos pode indicar os ambientes citados.

A sedimentação dos gastrópodes nos depósitos provavelmente ocorre em maior quantidade no período de seca, ou seja, no inverno, quando parte deles morre, ou está em áreas de menor dessecação. Nos períodos úmidos estão ativos, diminuindo a possibilidade de sua deposição.

Há a possibilidade de ocorrer deposição de gastrópodes durante as épocas de maior precipitação, pois o nível dos rios muda, depositando carbonato e conchas em áreas mais distantes das observadas no período de inverno, com menor nível de água. Estes gastrópodes, contudo, foram transportados fora da sua área de vida.

Segundo Pentecost (1995) as tufas calcárias estão limitadas a temperaturas entre 5$15^{\circ} \mathrm{C}$ com pluviosidade superior a $500 \mathrm{~mm}$ anuais. No entanto, no Brasil estas condições não são limitantes, pois as temperaturas das águas encontradas nos pontos visitados estão entre 18 e $22^{\circ} \mathrm{C}$ no período seco. Ou seja, para os climas tropicais as condições de formação de tufas calcárias são diferentes, pois a temperatura da água apresenta média superior aquelas dos locais temperados, assim como a pluviosidade.

A maior quantidade de água nos meses de dezembro a março (Figura 54) pode contribuir para os processos de intemperismo, ocorrendo significativa precipitação de carbonato apenas nos períodos de seca, induzida por altas taxas de evaporação.

Caso esta hipótese seja verdadeira a deposição de tufas calcárias na Serra da Bodoquena ocorreria entre os meses de abril e novembro, principalmente de julho a outubro, quando a taxa de evaporação supera a taxa de precipitação.

O processo de intemperismo modifica os depósitos micríticos como visto na Mineração Calcário Xaraés e na antiga área de mineração no centro de Bonito, assim como nos depósitos visitados que não apresentavam cobertura vegetal. Isto mostra que não ocorrem dois tipos de micritos, um consolidado e outro não, há modificação do micrito inconsolidado por ações intempéricas, que pode reduzir o depósito por dissolução, compactação e recristalização do carbonato nos espaços vazios, modificando também sua cor. 


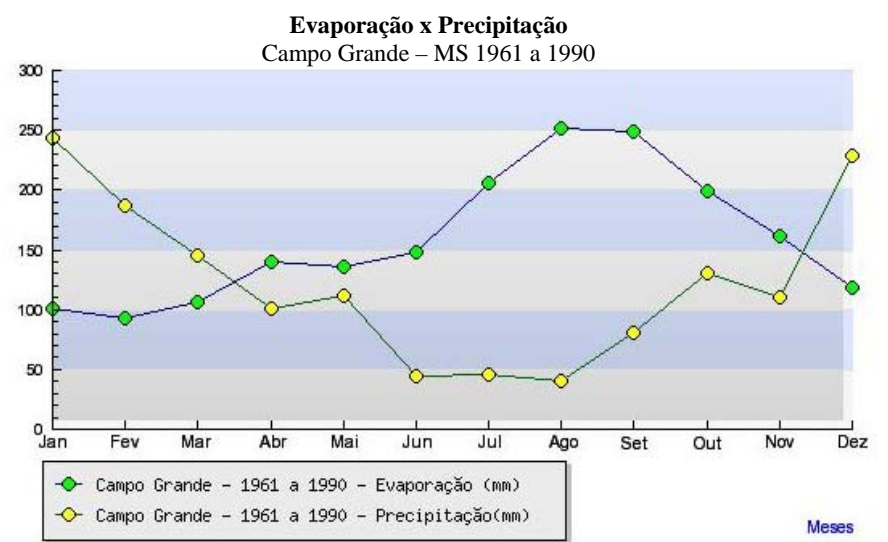

Figura 54 - Gráfico evaporação x precipitação em Campo Grande-MS das médias mensais de 1961 a 1990 seguindo as normas climatológicas do Instituto Nacional de Meteorologia. Extraído de: IMET - Instituto Nacional de Meteorologia.

Fósseis de carapaças mais delgadas, como no caso dos ostracodes, devem resistir menos a dissolução. Talvez este seja o motivo da ausência destes fósseis na antiga mineração de Bonito.

Já a vegetação também provoca intemperismo nos depósitos, no entanto, de forma mais lenta e oposta, como observado no depósito da antiga mineração no centro de Bonito, que mostra os dois tipos de depósitos. Há desagregação da rocha, ao contrário da compactação nos depósitos intemperizados, por ação das raízes e conseqüente penetração de água, maior concentração de argilominerais e restos orgânicos, levando a formação de um solo. 


\section{RESULTADOS FÍSICOS E QUÍMICOS}

\subsection{Granulometria e teor de carbonato}

Os dados granulométricos foram coletados baseados na escala de Wenthwort, e posteriormente agrupados nas frações grânulo, areia, silte e argila, representados em porcentagem na Tabela 02, bem como a classificação granulométrica de acordo com Trefethen (1950).

O perfil elaborado, a partir da base até $0,5 \mathrm{~m}$, é constituído de silte argilo-arenoso, seguido por mais $0,5 \mathrm{~m}$ de argila siltosa e, a partir de $1 \mathrm{~m}$ até o topo, por silte argiloso (Tabela 02). A classificação de Shepard (1954) para silte argilo-arenoso deveria conter pelo menos $20 \%$ de areia, no entanto, a base do depósito possui proporção muito próxima a esta, diferente do restante do perfil, portanto, esta classificação não seria adequada à proposta do trabalho.

As ocorrências das frações grânulos são baixas em média de $0,06 \%$, no entanto, estes dados são mais confiáveis, com base no erro padrão da média e no desvio padrão mais próximos a zero (Tabela 03). Já as areias apresentam freqüência média de 6,28\%, enquanto silte e argila perfazem a maior parte do depósito, com 50,22 e 43,43\% respectivamente, com erro padrão da média próximos entre si, assim como desvio padrão.

Observando a Tabela 02 nota-se que os grânulos nas amostras do topo do perfil aparecem com baixa freqüência, apenas um ponto próximo a base possui maior concentração, mas menor que 1\%. A classe areia distribui-se em freqüência maior, e apenas em dois pontos próximos a base, com maior freqüência, justificando a classificação de silte argilo-arenoso para esta porção.

Já a classe silte aumenta em freqüência da base para o topo, com maior concentração entre 50 e 55\%, enquanto a classe argila apresenta concentração entre 35 e 45\%, apenas um ponto com freqüência alta no terceiro ponto do perfil da base para o topo, classificando esta porção como argilo siltoso.

Os dados de grânulo e areia são mais variáveis que silte e argila de acordo com o coeficiente de variação. A classe silte comporta-se de forma mais semelhante à distribuição normal que as demais, com assimetria e curtose mais próximas a zero (Tabela 03), enquanto a classe grânulo é a mais distante da distribuição normal. 
Tabela 02 - Proporções das classes granulométricas e classificação atribuída aos sedimentos da Mineração Calcário Xaraés e demais pontos estudados segundo Trefethen (1950). Topo do perfil é 5,16m. Exposição: amostras obtidas em porção expostas. Tradagem: amostras obtidas por coleta através de furo de trado.

\begin{tabular}{|c|c|c|c|c|c|c|}
\hline \multicolumn{7}{|c|}{ Classes granulométricas } \\
\hline \multicolumn{2}{|c|}{ Amostras } & \multirow{2}{*}{$\begin{array}{c}\text { Grânulo } \\
0,06\end{array}$} & \multirow{2}{*}{$\begin{array}{c}\text { Areia } \\
5,16\end{array}$} & \multirow{2}{*}{$\begin{array}{l}\text { Silte } \\
54,61\end{array}$} & \multirow{2}{*}{$\begin{array}{c}\text { Argila } \\
40,17\end{array}$} & \multirow{2}{*}{$\begin{array}{c}\text { Classe granulométrica } \\
\text { Silte argiloso }\end{array}$} \\
\hline Topo & 5,16 & & & & & \\
\hline \multirow{11}{*}{ 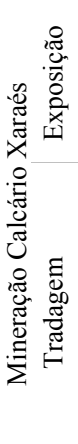 } & 4,46 & 0,08 & 4,22 & 59,76 & 35,93 & Silte argiloso \\
\hline & 3,96 & 0,02 & 2,31 & 52,71 & 44,96 & Silte argiloso \\
\hline & 3,46 & 0,15 & 5,17 & 55,36 & 39,31 & Silte argiloso \\
\hline & 2,96 & 0,00 & 3,02 & 53,68 & 43,30 & Silte argiloso \\
\hline & 2,36 & 0,00 & 4,27 & 51,85 & 43,88 & filoso \\
\hline & 2,18 & 0,00 & 5,16 & 50,81 & 44,04 & Silte argiloso \\
\hline & 2,08 & 0,00 & 7,92 & 50,72 & 41,36 & Silte argiloso \\
\hline & 1,94 & 0,00 & 1,78 & 51,22 & 47,00 & Silte argiloso \\
\hline & 1,38 & 0,00 & 2,23 & 54,66 & 43,11 & Silte argiloso \\
\hline & 1,06 & 0,00 & 5,28 & 36,66 & 58,06 & Argila siltosa \\
\hline & 0,51 & 0,61 & 18,77 & 43,98 & 36,64 & Silte argilo-arenoso \\
\hline Base & 0,01 & 0,00 & 17,59 & 46,57 & 35,84 & Silte argilo-arenoso \\
\hline \multirow{6}{*}{$\begin{array}{l}\stackrel{0}{0} \\
\stackrel{0}{0} \\
\stackrel{1}{0}\end{array}$} & 04 & 0,05 & 21,41 & 57,85 & 20,69 & Silte areno-argiloso \\
\hline & 06 & 0,22 & 35,78 & 53,05 & 10,95 & Silte arenoso \\
\hline & 07 & 0,00 & 14,54 & 72,14 & 13,32 & Silte \\
\hline & 14 & 1,97 & 13,13 & 47,14 & 37,76 & Silte argiloso \\
\hline & $16 \mathrm{~B}$ & 0,30 & 22,25 & 45,77 & 31,68 & Silte argilo-arenoso \\
\hline & $16 \mathrm{D}$ & 0,26 & 14,48 & 50,03 & 35,23 & Silte argilo-arenoso \\
\hline
\end{tabular}

Tabela 03 - Estatística descritiva dos dados granulométricos dos sedimentos da Mineração Calcário Xaraés.

\begin{tabular}{|c|c|c|c|c|c|c|c|c|c|c|c|c|}
\hline \multicolumn{13}{|c|}{ Resultados estatísticos para os dados granulométricos dos sedimentos da Mineração Calcário Xaraés } \\
\hline Variável & $\mathrm{N}$ & Média & $\begin{array}{c}\text { Erro padrão } \\
\text { da média }\end{array}$ & $\begin{array}{l}\text { Desvio } \\
\text { padrão }\end{array}$ & Mínimo & $1^{\circ}$ Quartil & Mediana & $3^{\circ}$ Quartil & $\begin{array}{l}\text { Coeficiente } \\
\text { de variação }\end{array}$ & Máximo & Assimetria & Curtose \\
\hline Grânulo & 14 & 0,06 & 0,04 & 0,16 & 0 & 0 & 0 & 0,06 & 248,20 & 0,61 & 3,31 & 11,49 \\
\hline Areia & 14 & 6,28 & 1,41 & 5,29 & 1,78 & 2,85 & 5,12 & 5,94 & 84,20 & 18,77 & 1,89 & 2,67 \\
\hline Silte & 14 & 50,22 & 1,67 & 6,26 & 36,66 & 45,92 & 51,53 & 54,63 & 12,47 & 59,76 & $-0,90$ & 0,49 \\
\hline Argila & 14 & 43,43 & 1,73 & 6,46 & 35,84 & 38,64 & 43,20 & 45,47 & 14,88 & 58,06 & 1,07 & 1,05 \\
\hline
\end{tabular}

Amostras de micrito de outras localidades próximas da Mineração Xaraés, como antiga lavra (ponto 16), apresentam também o predomínio da fração silte.

Dentro todos os depósitos apenas 04A e 06A possuem fração areia mais significativa, sendo classificados respectivamente como silte areno-siltoso e silte arenoso. Estes dois depósitos encontram-se em processo de pedogênese e é provável que possuam maior influência do rio em sua formação, já que contém o bivalve Diplodon, espécie de influência fluvial.

O depósito 07 é o de granulometria mais uniforme, classificado apenas como silte. $\mathrm{O}$ depósito 14 tem a mesma litologia do depósito de micritos da Mineração Calcário Xaraés, apesar de possuir maior concentração da fração areia. 
Quanto ao teor de carbonatos, os micritos amostrados na tradagem da Mineração Calcário Xaraés são uniformes, em torno de 95 a 99\% de carbonatos. Na base dos depósitos micríticos ocorre camada de argila com teores variando de 45 e 55\% de carbonatos (Figura $55)$.

As porcentagens de carbonato dos demais depósitos variam de 60 a $100 \%$. Os depósitos $07,16 \mathrm{~B}$ e 16D possuem 100, 98 e $96 \%$ de carbonato respectivamente, enquanto 04 , 06 e 14 apresentam 80, 65 e 60\% nesta mesma ordem. Estes últimos três depósitos citados apresentam porcentagens reduzidas de carbonato em comparação com os demais provavelmente pela ação intempérica.

Os depósitos 16B e o 06 foram influenciados pelo crescimento de vegetação, contudo apresentam diferentes teores de carbonato, o que poderia indicar estágios intempéricos distintos, ou ainda causados por diferentes condições de deposição.
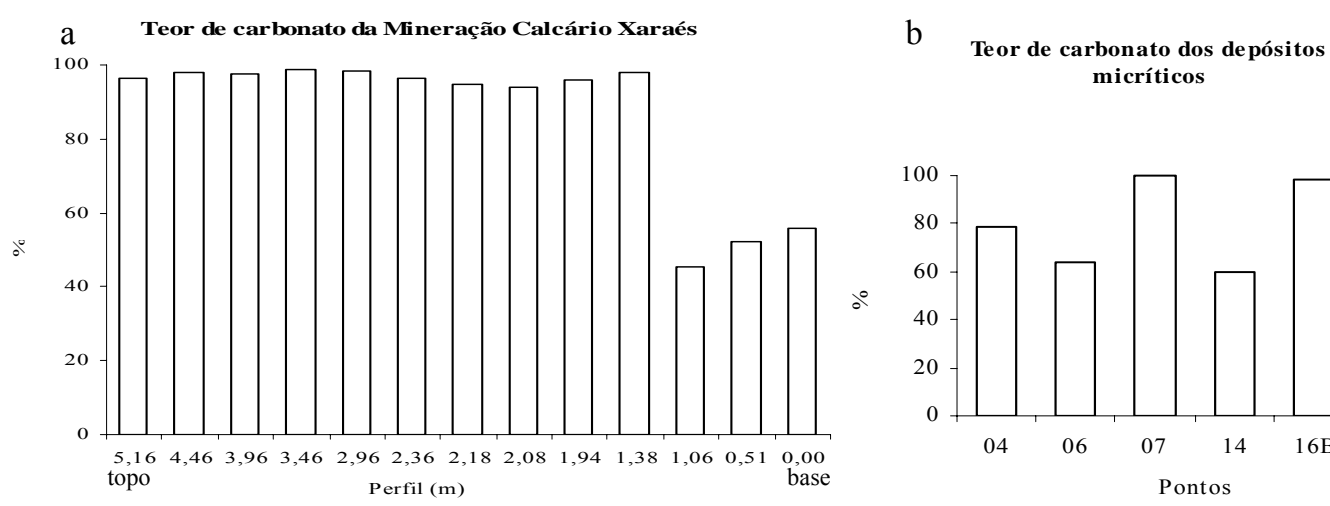
micríticos

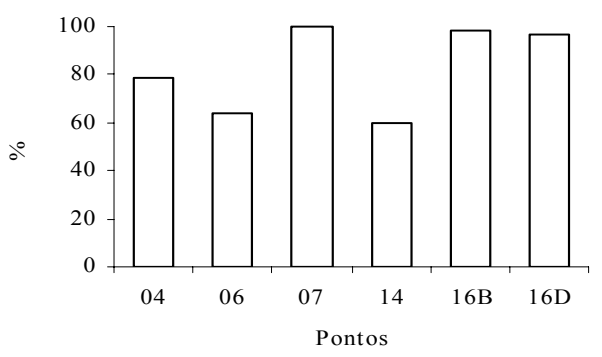

Figura 55 - Teor de carbonato dos depósitos da Mineração Calcário Xaraés. a) Teor de carbonato da Mineração Calcário Xaraés, o ponto no gráfico em 0 representa a base do depósito, e b) Os demais depósitos estudados.

\subsection{Identificação dos argilominerais}

A análise de difratometria de Raios $\mathrm{X}(\mathrm{DRX})$ mostrou a presença de calcita em todas as amostras.

Na Mineração Calcário Xaraés, as amostras 4,46 e 3,46, da porção exposta do depósito, e 2,36, 2,08 e 1,94, obtidas por meio de furo com trado, e o ponto 07 revelaram apenas calcita (Tabela 04). A caulinita é freqüente nos depósitos, mas em poucas 
concentrações, já que $\mathrm{SiO}_{2}$, nas amostras, representa menos de 1,5\% (Anexo B e C). A caulinita forma-se em ambientes bem drenados e em condições ácidas (Gomes, 1988), mostrando certo grau de intemperismo no depósito.

A associação caulinita e gibsita indica altos graus de intemperismos, e em menor intensidade intempérica a associação mica e caulinita (Jackson \& Sherman, 1963). Observando a Tabela 04 nota-se a presença no depósito da MCX, em 1,38, e nos depósitos 04, 06 e 14, caulinita associada a mica, enquanto nas porções 2,18, 1,06, 0,51 e 0,01, da Mineração, há a associação de caulinita e gibsita, demonstrando maior intemperismo nestas últimas porções, apesar disto, também ocorre mica, possivelmente sugerindo um intemperismo irregular do depósito.

Outra hipótese para a presença de mica, caulinita e gibsita no depósito é o intemperismo por percolação de água, removendo os minerais das porções superiores do depósito da Mineração Calcário Xaraés, transportando-os para as porções inferiores, além da possibilidade da água freática intemperizar os minerais nestas porções. Segundo Lucas et al. (1993) nos solos tropicais a caulinita é estável nas porções superiores, com intenso controle biológico, e gibsita precipita nas áreas mais profundas, corroborando com os dados observados para o perfil da Mineração Calcário Xaraés.

A ausência de calcita magnesiana ocorre devido aos baixos teores de magnésio observados (Anexo B e C), maiores nos depósitos 04 e 16B e D, onde ocorre calcita magnesiana.

O ponto 2,18m da Mineração foi o único a apresentar Cordierita, assim como a ocorrência de Hidrocalumita em 3,96. Já o ponto 5,16m, que representa o topo do depósito da Mineração Calcário Xaraés, apresentou Mbobomkulita (Tabela 04), registrada apenas em cavernas, é formada pela oxidação e lavagem de $\mathrm{Ni}-\mathrm{Cu}$ por sulfito no teto de cavernas, reagindo com filosilicatos e nitrato de guano (Anthony et al., 2001). Na região da Serra da Bodoquena a ocorrência de cavernas é muito grande, sendo possível sua formação e transporte para o depósito da Mineração Calcário Xaraés.

Apenas nos pontos 5,16 e 3,96 foi identificada Trona (Tabela 04). Formada em ambiente de alta evaporação (Eugster, 1980), pode indicar dois períodos de altas temperaturas. 
Tabela 04 - Argilominerais e calcita identificados nas análises de DRX para os sedimentos da Mineração Calcário Xaraés e demais depósitos da Serra da Bodoquena. Exposição: amostras obtidas em porção expostas. Tradagem: amostras obtidas por coleta através de furo de trado.

\begin{tabular}{|c|c|c|c|c|c|c|c|c|c|c|c|c|}
\hline \multicolumn{13}{|c|}{ Argilominerais identificados por DRX } \\
\hline \multicolumn{2}{|c|}{ Amostras } & $\frac{\frac{\pi}{0}}{\frac{\pi}{\pi}}$ & 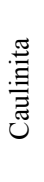 & 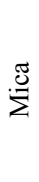 & $\begin{array}{l}\stackrel{\mathbb{n}}{5} \\
\frac{0}{0}\end{array}$ & 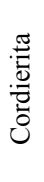 & 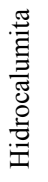 & 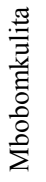 & $\underset{\mathscr{Z}}{\stackrel{\Xi}{0}}$ & 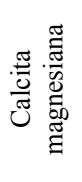 & 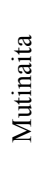 & ن \\
\hline \multirow{5}{*}{ 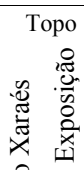 } & 5,16 & $\mathrm{X}$ & $\mathrm{X}$ & & & & & $\mathrm{X}$ & $\mathrm{X}$ & & & \\
\hline & 4,46 & $X$ & & & & & & & & & & \\
\hline & 3,96 & $X$ & $X$ & & & & $\mathrm{X}$ & & $\mathrm{X}$ & & & \\
\hline & 3,46 & $X$ & & & & & & & & & & \\
\hline & 2,96 & $X$ & $X$ & & & & & & & & & \\
\hline \multirow{7}{*}{ 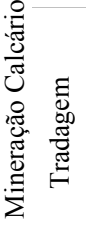 } & 2,36 & $\mathrm{X}$ & & & & & & & & & & \\
\hline & 2,18 & $X$ & $X$ & $X$ & $X$ & $\mathrm{X}$ & & & & & & \\
\hline & 2,08 & $\mathrm{X}$ & & & & & & & & & & \\
\hline & 1,94 & $X$ & & & & & & & & & & \\
\hline & 1,38 & $X$ & $X$ & $\mathrm{X}$ & & & & & & & $X$ & $\mathrm{X}$ \\
\hline & 1,06 & $X$ & $X$ & $X$ & $X$ & & & & & & & \\
\hline & 0,51 & $X$ & $X$ & $X$ & $X$ & & & & & & & \\
\hline Base & 0,01 & $X$ & $X$ & $X$ & $X$ & & & & & & & \\
\hline \multirow{6}{*}{ 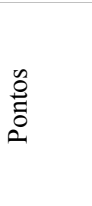 } & 04 & $X$ & $X$ & $X$ & & & & & & $X$ & & \\
\hline & 06 & $X$ & $X$ & $X$ & & & & & & & $X$ & $X$ \\
\hline & 07 & $\mathrm{X}$ & & & & & & & & & & \\
\hline & 14 & $X$ & $X$ & $X$ & & & & & & & & \\
\hline & $16 \mathrm{~B}$ & $X$ & & & & & & & & $X$ & & \\
\hline & $16 \mathrm{D}$ & $\mathrm{X}$ & & & & & & & & $X$ & & \\
\hline
\end{tabular}

A ocorrência de Trona no depósito, assim como os demais argilominerais, pode ser questionada quanto a baixa concentração de seus constituintes na amostra (Anexo C). No caso de Trona, no entanto, os íons bicarbonato $\left(\mathrm{HCO}_{3}{ }^{-}\right)$estavam disponíveis de acordo com a presença de $\mathrm{CaO}$ em grande quantidade na amostra, pré-requisito para sua formação, assim como a presença de $\mathrm{CO}_{2}$ de origem vegetal (Erman et al., 2005).

Os pontos 16B, 16D e 07 possuem alta porcentagem composicional de $\mathrm{CaO}$ (Anexo C) da mesma forma que o perfil da Mineração Calcário Xaraés, justificando somente a presença de calcita nas amostras.

Ocorre ainda a associação de Mutinaita e coctaita no ponto 1,38 da Mineração e no depósito 06. A ausência de aragonita pode ser explicada pela elevada sensibilidade às condições ambientais convertendo-se em calcita. 
5.3. Análise de elementos maiores, menores e traços

A análise dos elementos maiores, menores e traços foi tratada por método estatístico de análise multivariada de componentes principais. Esta análise reduz o número de variáveis matematicamente, transformando-as em componentes principais, geradas por sua combinação linear. Cada componente gerada possui valor (autovalor) que representa uma porcentagem das combinações obtidas. A análise de agrupamento cria grupos homogêneos e mutuamente excludentes entre si, baseado nas variáveis, com objetivo classificatório (Manly, 1994; Hair et al., 2005). Os valores dos componentes, gráficos e agrupamentos foram gerados no programa Minitab 15.1.

Como trata-se de uma análise estatística, os elementos maiores, menores e traços serão tratados como variáveis, chamadas de elementos composicionais. As amostras da Mineração Calcário Xaraés foram coletadas em porção exposta do depósito, complementado por furo de trado, compondo um perfil. Foram analisadas em três etapas: a) todo o perfil b) perfil sem os pontos referentes a porção de argila na base e c) perfil, sem as amostras da base compostas de argila, mais as amostras dos depósitos 04, 06, 14, 16B e 16D.

\subsubsection{Mineração Calcário Xaraés}

Os dados de $\mathrm{Cl}, \mathrm{Nb}, \mathrm{Nd}$ e $\mathrm{S}$ não foram constatados em nenhuma amostra, por isso foram excluídos da análise multivariada para o perfil da Mineração Calcário Xaraés. A tabela original dos valores obtidos está no Anexo B. Foram gerados 29 componentes principais, sendo os primeiros 11 correspondentes a 99,99\% das contribuições na variância do conjunto, e os dois primeiros representando $75,4 \%$ da contribuição, utilizados para a análise (Tabela 05 , 02 e Figura 56 a).

Os elementos composicionais $\mathrm{SiO}_{2}, \mathrm{Al}_{2} \mathrm{O}_{3}, \mathrm{Ba}, \mathrm{TiO}_{2}, \mathrm{~K}_{2} \mathrm{O}, \mathrm{Cu}, \mathrm{Ga}, \mathrm{Ni}, \mathrm{Cr}, \mathrm{Co}, \mathrm{Na}_{2} \mathrm{O}$ e Ce são fortemente influenciados pelos três pontos da base do depósito (Figura 56 e Tabela 06). A Figura 57 mostra a análise de agrupamento das amostras do perfil, definindo a similaridade entre elas e seu isolamento dos demais pontos. A Figura $56 \mathrm{~d}$ também mostra os pontos relativos a base do perfil distinguindo-os dos demais. 

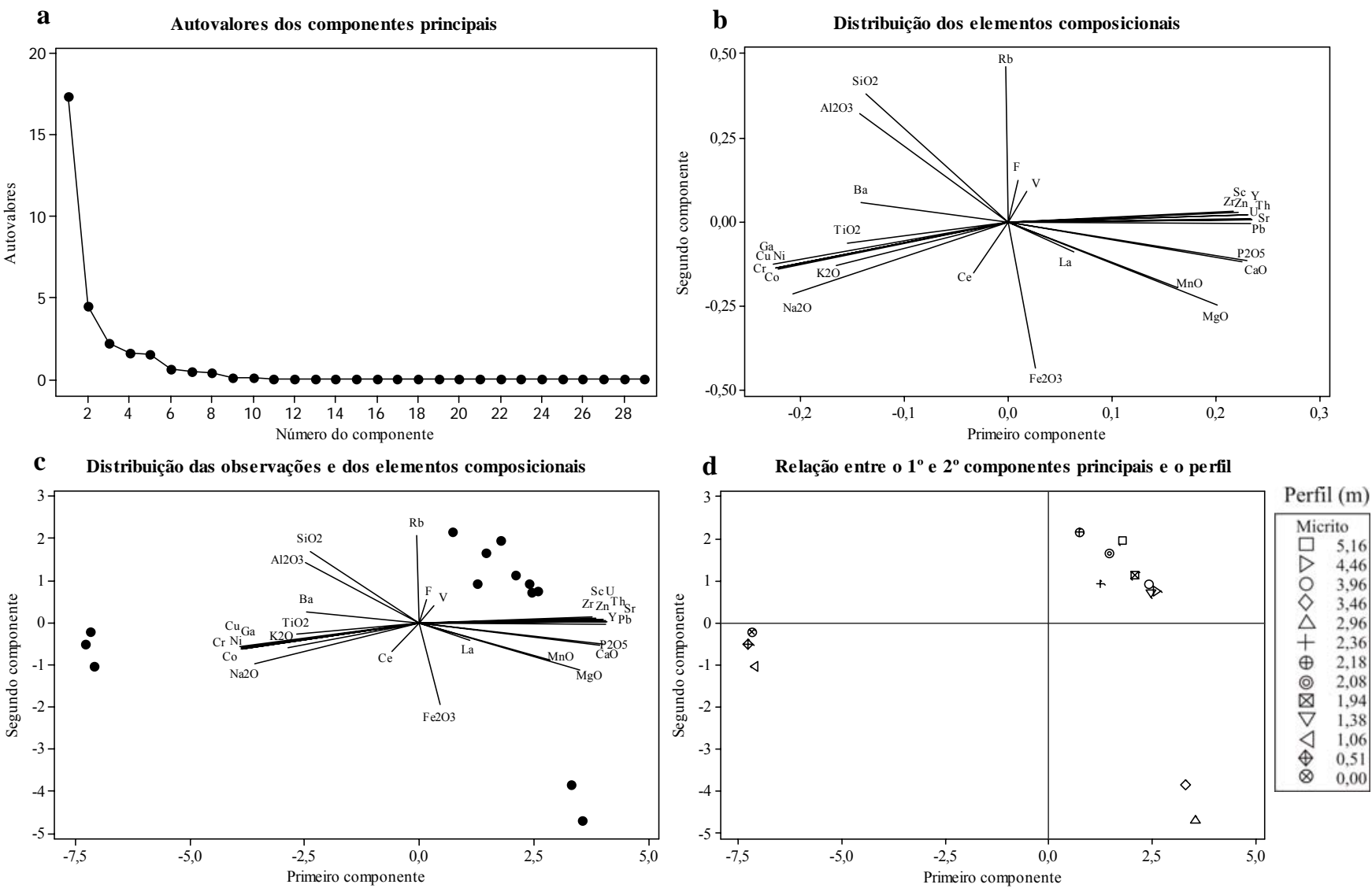

Figura 56 - Gráficos obtidos da análise multivariada dos elementos composicionais do perfil da Mineração Calcário Xaraés. a) Autovalores dos componentes principais. b) Distribuição dos elementos composicionais nos $1^{\mathrm{a}}$ e $2^{\mathrm{a}}$ componentes principais. c) Distribuição das observações e dos elementos composicionais. d) Relação entre o $1^{\mathrm{a}} \mathrm{e} 2^{\mathrm{a}}$ componente principal. Xaraés.

Tabela 05 - Análise da \% de contribuição dos componentes principais do perfil da Mineração Calcário

\begin{tabular}{crrrrrrrrrrr}
\hline \multicolumn{10}{c}{ Análise da \% de contribuição dos componentes principais } \\
\hline & PC1 & PC2 & PC3 & PC4 & PC5 & PC6 & PC7 & PC8 & PC9 & PC10 & PC11 \\
\hline Autovalores & 17,400 & 4,470 & 2,217 & 1,622 & 1,524 & 0,66 & 0,479 & 0,366 & 0,128 & 0,078 & 0,034 \\
Proporção & 0,600 & 0,154 & 0,076 & 0,056 & 0,053 & 0,023 & 0,017 & 0,013 & 0,004 & 0,003 & 0,001 \\
Acumulado & 0,600 & 0,754 & 0,831 & 0,887 & 0,939 & 0,962 & 0,978 & 0,991 & 0,995 & 0,998 & 0,999 \\
\hline
\end{tabular}


Tabela 06 - 10 primeiros componentes principais gerados da análise multivariada do perfil da Mineração Calcário Xaraés.

\begin{tabular}{|c|c|c|c|c|c|c|c|c|c|c|c|}
\hline \multicolumn{12}{|c|}{1 primeiras componentes principais do perfil da Mineração Calcário Xaraés } \\
\hline Variáveis & $\mathrm{PC} 1$ & $\mathrm{PC} 2$ & $\mathrm{PC} 3$ & PC4 & PC5 & PC6 & PC7 & PC8 & PC9 & $\mathrm{PC} 10$ & PC11 \\
\hline $\mathrm{SiO}_{2}$ & $-0,137$ & 0,382 & 0,086 & & 0,001 & & $-0,004$ & & & & $-0,142$ \\
\hline $\mathrm{A} 12 \mathrm{O}_{3}$ & $-0,143$ & 0,324 & 0,001 & 0,009 & 0,247 & $-0,183$ & 0,274 & 0,155 & 0,063 & 0,353 & 0,337 \\
\hline $\mathrm{MnO}$ & 0,163 & $-0,196$ & 0,143 & $-0,315$ & $-0,017$ & $-0,045$ & 0,161 & 0,618 & $-0,013$ & 0,020 & $-0,089$ \\
\hline $\mathrm{MgO}$ & 0,200 & $-0,247$ & $-0,072$ & 0,010 & $-0,011$ & 0,117 & $-0,026$ & $-0,079$ & $-0,086$ & $-0,047$ & 0,250 \\
\hline $\mathrm{CaO}$ & 0,230 & $-0,115$ & $-0,026$ & 0,068 & $-0,043$ & 0,104 & $-0,027$ & 0,013 & 0,005 & $-0,102$ & $-0,004$ \\
\hline $\mathrm{Na}_{2} \mathrm{O}$ & $-0,207$ & $-0,214$ & $-0,038$ & $-0,003$ & $-0,139$ & 0,007 & $-0,086$ & $-0,081$ & 0,025 & $-0,276$ & $-0,241$ \\
\hline $\mathrm{K}_{2} \mathrm{O}$ & $-0,165$ & $-0,129$ & $-0,202$ & 0,236 & 0,332 & $-0,164$ & 0,113 & $-0,028$ & $-0,778$ & & $-0,053$ \\
\hline $\mathrm{TiO}_{2}$ & $-0,154$ & $-0,062$ & $-0,230$ & 0,240 & 0,384 & $-0,126$ & 0,352 & 0,277 & 0,381 & & 0,148 \\
\hline $\mathrm{P}_{2} \mathrm{O}_{5}$ & 0,225 & $-0,119$ & $-0,041$ & 0,051 & 0,044 & 0,012 & $-0,054$ & $-0,281$ & 0,064 & 0,001 & 0,573 \\
\hline $\mathrm{Fe}_{2} \mathrm{O}_{3}$ & 0,027 & $-0,434$ & $-0,118$ & $-0,047$ & 0,180 & 0,120 & 0,058 & 0,014 & 0,310 & 0,693 & $-0,174$ \\
\hline $\mathrm{Ba}$ & $-0,142$ & 0,058 & 0,162 & 0,198 & 0,313 & 0,729 & 0,121 & $-0,108$ & 0,040 & $-0,032$ & $-0,121$ \\
\hline $\mathrm{Ce}$ & & & & & & & & & & & 0,193 \\
\hline $\mathrm{Co}$ & $-0,221$ & $-0,141$ & $-0,051$ & 0,070 & $-0,128$ & $-0,154$ & 0,001 & $-0,088$ & 0,080 & 0,004 & $-0,049$ \\
\hline $\mathrm{Cr}$ & $-0,226$ & $-0,124$ & $-0,044$ & 0,064 & $-0,121$ & $-0,124$ & 0,005 & $-0,051$ & 0,071 & 0,072 & 0,066 \\
\hline $\mathrm{Cu}$ & $-0,223$ & $-0,137$ & $-0,049$ & 0,066 & $-0,124$ & $-0,148$ & 0,003 & $-0,079$ & 0,079 & 0,028 & $-0,009$ \\
\hline $\mathrm{F}$ & & & & & & & & & $-0,097$ & & 0,095 \\
\hline $\mathrm{Ga}$ & $-0,223$ & $-0,137$ & $-0,048$ & 0,060 & $-0,120$ & $-0,148$ & 0,006 & $-0,076$ & 0,079 & & 0,015 \\
\hline $\mathrm{La}$ & 0,063 & $-0,090$ & 0,061 & $-0,574$ & 0,409 & $-0,290$ & 0,035 & $-0,330$ & 0,031 & $-0,139$ & $-0,106$ \\
\hline $\mathrm{Ni}$ & $-0,223$ & $-0,134$ & $-0,048$ & 0,067 & $-0,125$ & $-0,142$ & 0,001 & $-0,077$ & 0,076 & 0,018 & $-0,022$ \\
\hline $\mathrm{Pb}$ & & & & & & & & & $-0,024$ & & 0,009 \\
\hline $\mathrm{Rb}$ & $-0,003$ & & 0,066 & 0,006 & $-0,058$ & $-0,121$ & $-0,063$ & $-0,110$ & 0,160 & 0,122 & $-0,059$ \\
\hline $\mathrm{Sc}$ & 0,222 & 0,029 & 0,026 & $-0,193$ & 0,220 & $-0,040$ & 0,052 & $-0,083$ & $-0,065$ & $-0,105$ & $-0,156$ \\
\hline $\mathrm{Sr}$ & 0,235 & 0,006 & $-0,033$ & 0,147 & $-0,020$ & $-0,056$ & 0,025 & $-0,048$ & $-0,003$ & $-0,025$ & $-0,059$ \\
\hline Th & 0,234 & 0,006 & $-0,032$ & & $-0,036$ & $-0,069$ & & & 0,034 & & 0,083 \\
\hline $\mathrm{U}$ & 0,233 & $-0,005$ & $-0,021$ & 0,147 & $-0,053$ & $-0,116$ & $-0,001$ & $-0,050$ & 0,086 & 0,051 & 0,089 \\
\hline V & 0,019 & 0,093 & $-0,352$ & $-0,284$ & $-0,413$ & 0,204 & 0,717 & $-0,197$ & $-0,099$ & $-0,002$ & $-0,014$ \\
\hline Y & 0,230 & 0,020 & $-0,043$ & 0,190 & $-0,039$ & $-0,104$ & 0,078 & 0,045 & 0,030 & 0,014 & $-0,284$ \\
\hline $\mathrm{Zn}$ & 0,231 & 0,021 & $-0,057$ & 0,164 & $-0,020$ & $-0,134$ & 0,092 & $-0,029$ & $-0,015$ & 0,044 & $-0,075$ \\
\hline $\mathrm{Zr}$ & 0,217 & 0,033 & $-0,045$ & 0,296 & $-0,002$ & $-0,163$ & 0,119 & 0,032 & 0,066 & $-0,022$ & $-0,377$ \\
\hline
\end{tabular}
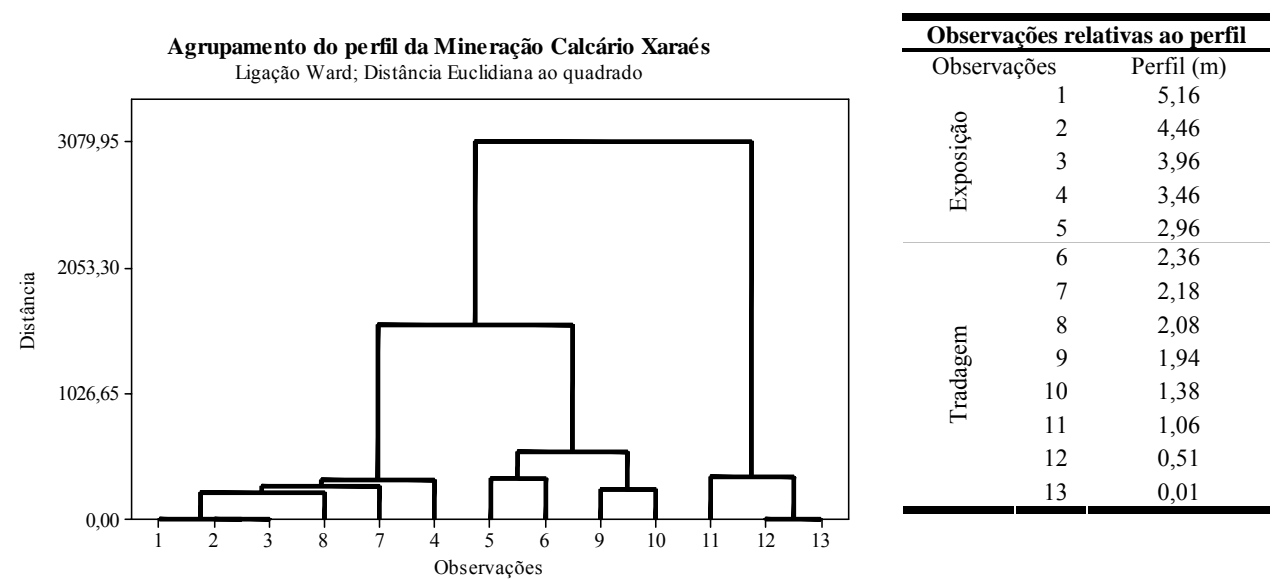

Figura 57 - Análise de agrupamento. a) Análise de agrupamento do perfil da Mineração Calcário Xaraés. b) Observações relativas aos pontos no perfil. 5,16m equivale ao topo do depósito. Exposição: amostras obtidas em porção expostas. Tradagem: amostras obtidas por coleta através de furo de trado. 


\subsubsection{Micritos da Mineração Calcário Xaraés}

A partir dos resultados obtidos das amostras da Mineração, a análise multivariada foi feita com a exclusão dos três pontos da base do depósito, para melhor definição dos micritos puros.

Foram excluídos da análise multivariada dos micritos puros do perfil da Mineração Calcário Xaraés, os dados de $\mathrm{Cl}, \mathrm{Cr}, \mathrm{Co}, \mathrm{Cu}, \mathrm{Ga}, \mathrm{La}, \mathrm{Nb} . \mathrm{Nd}, \mathrm{Ni}, \mathrm{S}$ e $\mathrm{Na}_{2} \mathrm{O}$, pois não foram constatados em nenhuma amostra. Foram gerados 22 componentes principais, sendo as primeiras 8 correspondentes a 99,6\% das contribuições na variância do conjunto, e os dois primeiros representando $73 \%$ da contribuição, utilizados para a análise (Tabela 07, 08 e Figura 58 a).

Tabela 07 - Análise da \% de contribuição dos componentes principais dos micritos da Mineração Calcário Xaraés.

\begin{tabular}{lrrrrrrrr}
\hline \multicolumn{8}{c}{ Análise da \% de contribuição das componentes principais } \\
\hline & PC1 & PC2 & PC3 & PC4 & PC5 & PC6 & PC7 & PC8 \\
\hline Autovalores & 13,078 & 2,977 & 2,239 & 2,062 & 0,672 & 0,556 & 0,214 & 0,121 \\
Proporção & 0,594 & 0,135 & 0,102 & 0,094 & 0,031 & 0,025 & 0,010 & 0,006 \\
Acumulado & 0,594 & 0,730 & 0,832 & 0,925 & 0,956 & 0,981 & 0,991 & 0,996 \\
\hline
\end{tabular}

Os elementos composicionais analisados apenas para o topo do depósito distribuem-se com peso uniforme para os pontos do perfil. Apenas $\mathrm{Ba}, \mathrm{F}, \mathrm{V}, \mathrm{TiO}_{2}$ e $\mathrm{K}_{2} \mathrm{O}$ com menores contribuições (Figura 58 e Tabela 08).

Os pontos 5,16 (topo), 2,18 e 2,08m têm maiores influências de $\mathrm{Al}_{2} \mathrm{O}_{3}, \mathrm{Si}_{2} \mathrm{O}$ e Rb. Já $\mathrm{F}$ e V são mais relevantes nos intervalos 5,16 a 3,96m e 2,08 a 1,94m. O elemento Ba é mais representativo entre 2,36 e 2,18m e em 1,38. Os outros 16 elementos composicionais possuem maiores influências apenas no intervalo 3,46 a 2,96m (Figura 58). Apesar disto, este grupo de elementos também se divide entre os dois pontos como mostra a Figura $58 \mathrm{~d}$.

O fato destes dois pontos, 2,96 e 3,46, possuírem vários elementos em comum, não influenciou seu agrupamento (Figura 59), já que se apresentam em grupos distintos.

Podem ser definidos três grupos principais na análise de agrupamento, um composto pelos dois primeiros pontos de micritos puros do perfil do depósito da Mineração (observações 9 e 10 da Figura 59). O segundo grupo contendo o intervalo 2,96 e 2,36m, 
(observações 5 e 6 da Figura 59). E um terceiro grupo, pouco definido, com as demais observações. Nota-se neste terceiro grupo que as observações relativas ao topo do depósito, intervalo 5,16 a 3,96m, mostram-se muito próximas quanto à medida de distância utilizada na análise.

Constatados os grupos no perfil da Mineração Calcário Xaraés, os demais depósitos foram analisados em conjunto com o perfil para procurar semelhanças entre eles.
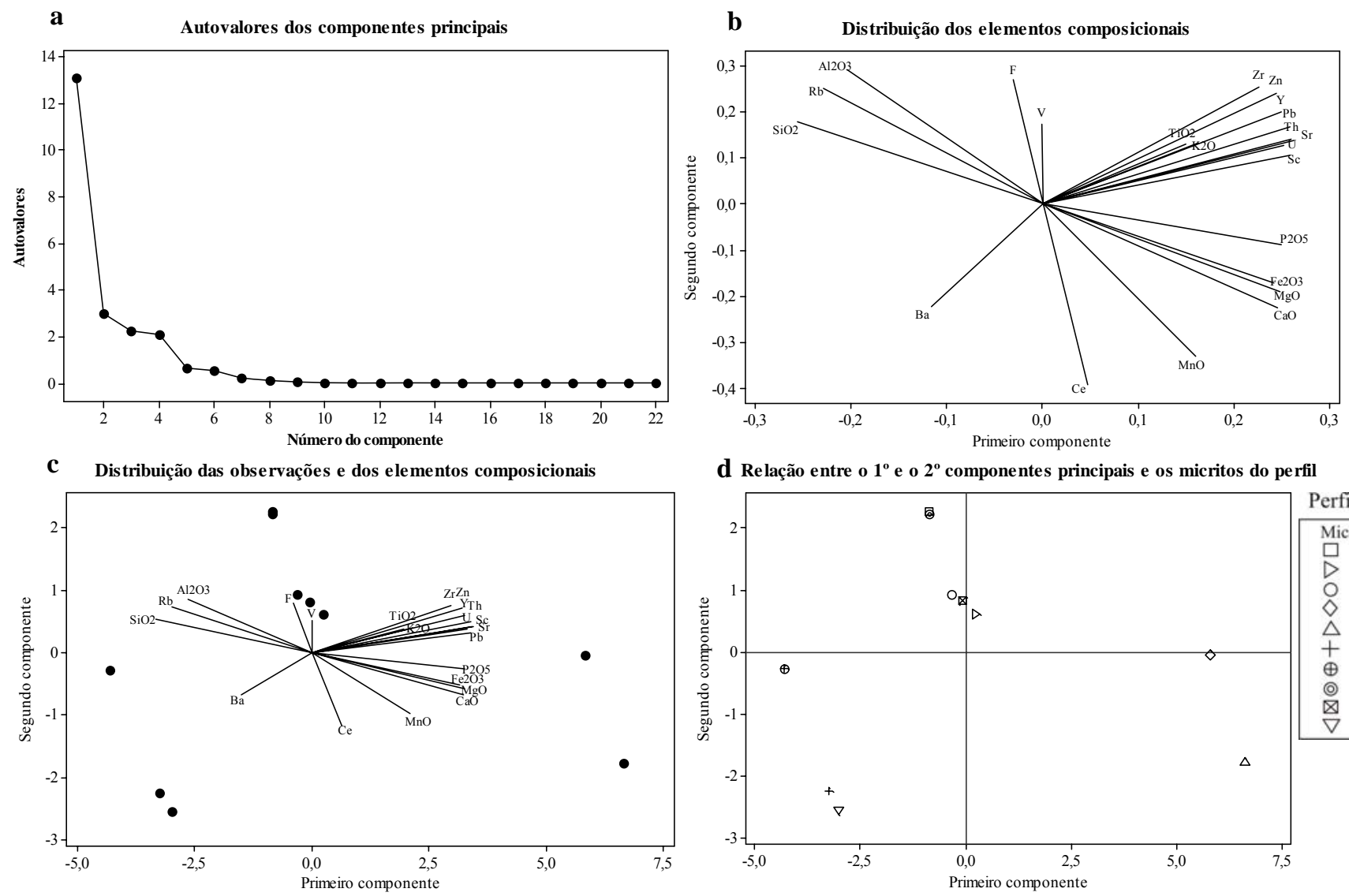

d Relação entre o $1^{\circ}$ e o $2^{\circ}$ componentes principais e os micritos do perfil

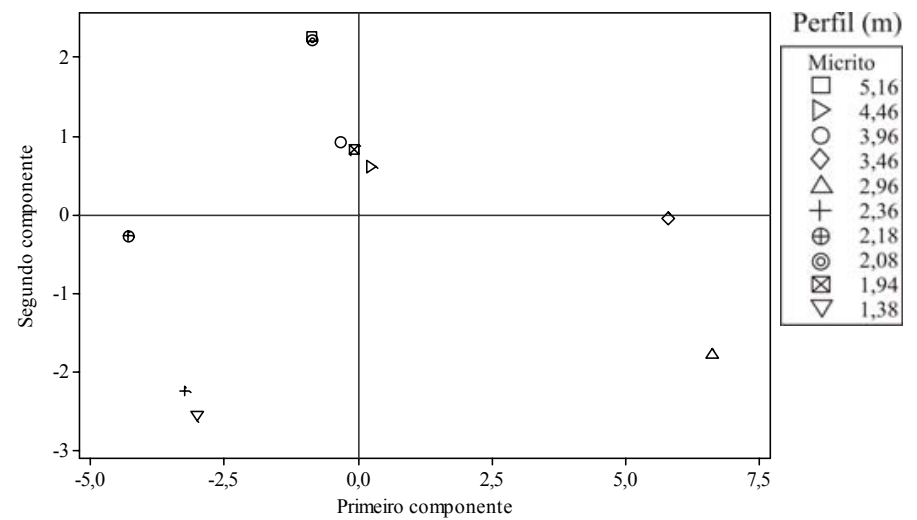

Figura 58 - Gráficos obtidos da análise multivariada dos elementos composicionais do perfil da Mineração Calcário Xaraés sem os pontos referentes a base. a) Autovalores das componentes principais. b) Distribuição dos elementos composicionais nas $1^{\mathrm{a}} \mathrm{e} 2^{\mathrm{a}}$ componentes principais. c) Distribuição das observações e dos elementos composicionais. d) Relação entre a $1^{\mathrm{a}} \mathrm{e} 2^{\mathrm{a}}$ componente principal. 


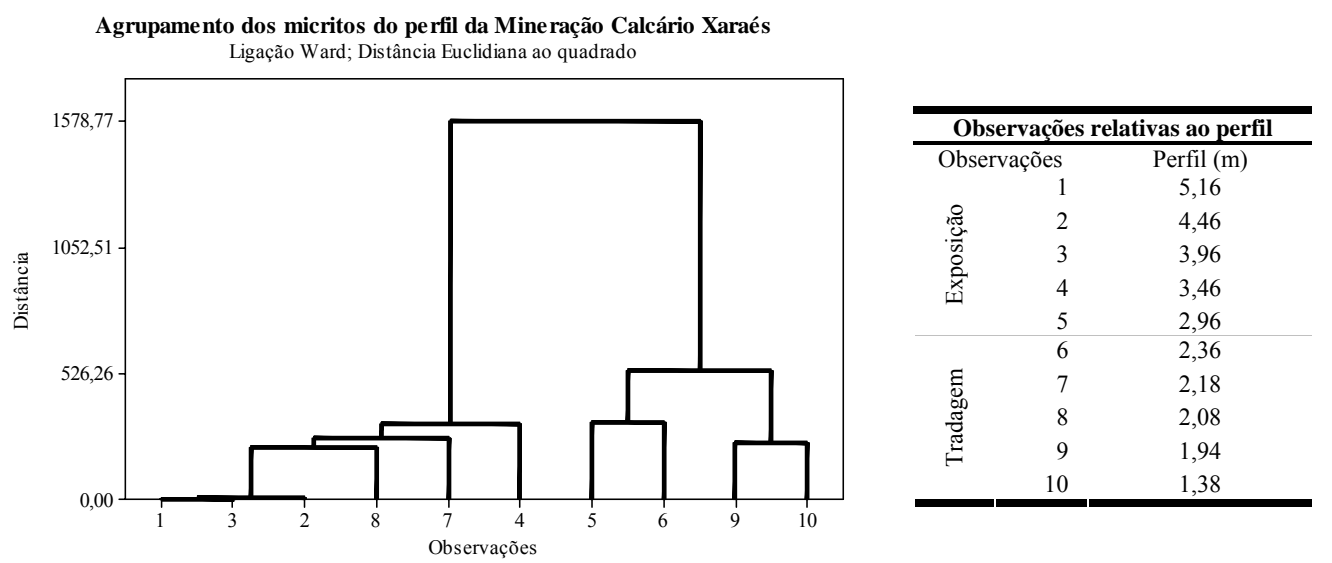

Figura 59 - Análise de agrupamento. a) Análise de agrupamento do perfil da Mineração Calcário Xaraés sem os três pontos referentes a base. b) Observações relativas aos pontos no perfil. 5,16m equivale ao topo do depósito. Exposição: amostras obtidas em porção expostas. Tradagem: amostras obtidas por coleta através de furo de trado.

Tabela $08-8$ primeiros componentes principais gerados da análise multivariada do perfil da Mineração Calcário Xaraés sem os três pontos da base.

\begin{tabular}{|c|c|c|c|c|c|c|c|c|}
\hline \multicolumn{9}{|c|}{8 primeiros componentes principais do perfil da Mineração Calcário Xaraés } \\
\hline Variáveis & PC1 & PC2 & PC3 & PC4 & PC5 & PC6 & PC7 & PC8 \\
\hline $\mathrm{SiO}_{2}$ & $-0,256$ & 0,177 & 0,109 & $-0,103$ & $-0,011$ & $-0,009$ & $-0,054$ & $-0,091$ \\
\hline $\mathrm{Al}_{2} \mathrm{O}_{3}$ & $-0,204$ & 0,289 & $-0,102$ & $-0,212$ & 0,272 & $-0,100$ & 0,184 & 0,475 \\
\hline $\mathrm{MnO}$ & 0,160 & $-0,328$ & 0,154 & 0,157 & 0,588 & 0,116 & 0,021 & $-0,084$ \\
\hline $\mathrm{MgO}$ & 0,249 & $-0,191$ & $-0,088$ & 0,160 & $-0,123$ & $-0,019$ & $-0,056$ & 0,028 \\
\hline $\mathrm{CaO}$ & 0,246 & $-0,224$ & $-0,036$ & 0,162 & $-0,071$ & 0,019 & 0,052 & $-0,051$ \\
\hline $\mathrm{K}_{2} \mathrm{O}$ & 0,163 & 0,132 & $-0,438$ & $-0,156$ & 0,077 & 0,053 & $-0,694$ & 0,314 \\
\hline $\mathrm{TiO}_{2}$ & 0,150 & 0,130 & $-0,460$ & $-0,118$ & 0,361 & $-0,061$ & 0,456 & $-0,090$ \\
\hline $\mathrm{P}_{2} \mathrm{O}_{5}$ & 0,249 & $-0,087$ & $-0,051$ & 0,053 & $-0,451$ & $-0,030$ & 0,146 & 0,221 \\
\hline $\mathrm{Fe}_{2} \mathrm{O}_{3}$ & 0,241 & $-0,171$ & $-0,200$ & 0,078 & 0,009 & $-0,006$ & 0,219 & 0,069 \\
\hline $\mathrm{Ba}$ & $-0,115$ & $-0,223$ & $-0,425$ & $-0,265$ & $-0,218$ & $-0,391$ & 0,127 & $-0,185$ \\
\hline $\mathrm{Ce}$ & 0,048 & $-0,391$ & 0,335 & $-0,320$ & 0,219 & $-0,119$ & $-0,128$ & 0,260 \\
\hline $\mathrm{F}$ & $-0,030$ & 0,268 & $-0,199$ & 0,541 & 0,068 & 0,374 & 0,003 & 0,039 \\
\hline $\mathrm{Pb}$ & 0,259 & 0,168 & 0,101 & $-0,065$ & $-0,100$ & $-0,055$ & $-0,051$ & 0,032 \\
\hline $\mathrm{Rb}$ & $-0,229$ & 0,250 & 0,203 & $-0,076$ & $-0,138$ & 0,010 & 0,046 & $-0,261$ \\
\hline $\mathrm{Sc}$ & 0,259 & 0,105 & $-0,052$ & $-0,033$ & 0,099 & $-0,182$ & $-0,313$ & $-0,540$ \\
\hline $\mathrm{Sr}$ & 0,263 & 0,138 & 0,099 & $-0,069$ & $-0,106$ & $-0,003$ & 0,008 & $-0,005$ \\
\hline Th & 0,260 & 0,139 & 0,138 & $-0,056$ & $-0,088$ & $-0,017$ & 0,115 & 0,134 \\
\hline $\mathrm{U}$ & 0,253 & 0,126 & 0,190 & $-0,072$ & $-0,118$ & 0,096 & 0,199 & 0,195 \\
\hline V & $-0,001$ & 0,171 & 0,131 & 0,502 & 0,122 & $-0,783$ & $-0,050$ & 0,158 \\
\hline Y & 0,249 & 0,198 & 0,118 & $-0,104$ & 0,126 & $-0,001$ & 0,037 & $-0,149$ \\
\hline $\mathrm{Zn}$ & 0,244 & 0,240 & 0,116 & $-0,090$ & 0,023 & $-0,050$ & $-0,027$ & 0,052 \\
\hline $\mathrm{Zr}$ & 0,226 & 0,251 & 0,046 & $-0,245$ & 0,127 & $-0,017$ & 0,079 & $-0,157$ \\
\hline
\end{tabular}


5.3.3. Micritos da Mineração Calcário Xaraés e outros depósitos da Serra da Bodoquena

Os elementos $\mathrm{Cl}$ e $\mathrm{Nb}$ não foram constatados em nenhuma amostra, por isso foram excluídos da análise multivariada para os micritos do perfil da Mineração Calcário Xaraés e para os demais depósitos. Os dados originais estão no Anexo C. Foram gerados 31 componentes principais, sendo os primeiros 12 correspondentes a 99,9\% das contribuições na variância do conjunto, e os dois primeiros representando 60,4\% da contribuição (Tabela 09 e Figura 60 a).

A análise multivariada por componentes principais mostrou a separação entre os demais micritos estudados e aqueles do perfil da Mineração Calcário Xaraés (Figura 60). Os elementos não inseridos na análise apenas do perfil distribuem-se com maior intensidade para os demais pontos sendo o depósito 14 com maior contribuição de Ga, La, Co e Ni, 04 e 06 com maiores influências de $\mathrm{Cr}, \mathrm{Cu}$ e $\mathrm{Na}_{2} \mathrm{O}$, e S para 16D, 07 e 16B.

Os elementos $\mathrm{Ce}$ e $\mathrm{TiO} 2$ são mais influentes no perfil de micritos, enquanto $\mathrm{V}$ fortemente presente em 14. A mesma amostra também possui maiores influências de $\mathrm{Rb}, \mathrm{V}$, $\mathrm{K} 2 \mathrm{O}$, Ni e $\mathrm{SiO}_{2}$, enquanto, 04A e 06A tem maiores contribuições de $\mathrm{Cr}, \mathrm{Na}_{2} \mathrm{O}$, Cu e Ba.

Os pontos 07, 16B e 16D contêm os elementos $\mathrm{P}_{2} \mathrm{O}_{5}, \mathrm{Sc}, \mathrm{CaO}, \mathrm{MgO}, \mathrm{Fe}_{2} \mathrm{O}_{3}, \mathrm{MnO}, \mathrm{S}$, Nd e F com maior intensidade (Tabela 10 e Figura 60). As amostras 16B e 16D são do mesmo depósito, no entanto, a amostra 16D é de uma porção exposta intensamente intemperizada pelos agentes temperatura e chuva, já 16B é praticamente um solo, com poucas características visuais de micritos.

Tabela 09 - Análise da \% de contribuição dos componentes principais do perfil da Mineração Calcário Xaraés, sem as três amostras da base, e os demais pontos.

\begin{tabular}{crlllllllllll}
\hline \multicolumn{11}{c}{ Análise da \% de contribuição dos componentes principais } \\
\hline & PC1 & PC2 & PC3 & PC4 & PC5 & PC6 & PC7 & PC8 & PC9 & PC10 & PC11 & PC12 \\
\hline Autovalores & 12,209 & 6,529 & 4,408 & 2,393 & 1,634 & 1,381 & 1,024 & 0,546 & 0,433 & 0,246 & 0,115 & 0,066 \\
Proporção & 0,394 & 0,211 & 0,142 & 0,077 & 0,053 & 0,045 & 0,033 & 0,018 & 0,014 & 0,008 & 0,004 & 0,002 \\
Acumulado & 0,394 & 0,604 & 0,747 & 0,824 & 0,877 & 0,921 & 0,954 & 0,972 & 0,986 & 0,994 & 0,997 & 0,999 \\
\hline
\end{tabular}

Apesar de serem bem semelhantes quimicamente alguns elementos merecem destaque na diferenciação de $16 \mathrm{~B}$ e $16 \mathrm{D}$. A porção $16 \mathrm{~B}$ possui menores concentrações de $\mathrm{SiO}_{2}$ e $\mathrm{Fe}_{2} \mathrm{O}_{3}$, enquanto $\mathrm{CaO}, \mathrm{P}_{2} \mathrm{O}_{5}, \mathrm{~Pb}, \mathrm{Sr}$, Th e $\mathrm{U}$ apresentam-se em concentrações poucos maiores (Anexo 
C). Este depósito, entre os demais estudados, é o mais semelhante aos micritos da Mineração Calcário Xaraés, também já foi explorado com a mesma finalidade.

Já as amostras 04 e 06 também são depósitos de provável continuação lateral, 04 com influências intempéricas das águas do Rio Mimoso e 06 solo intemperizado ambos com crescimento de vegetação.

a
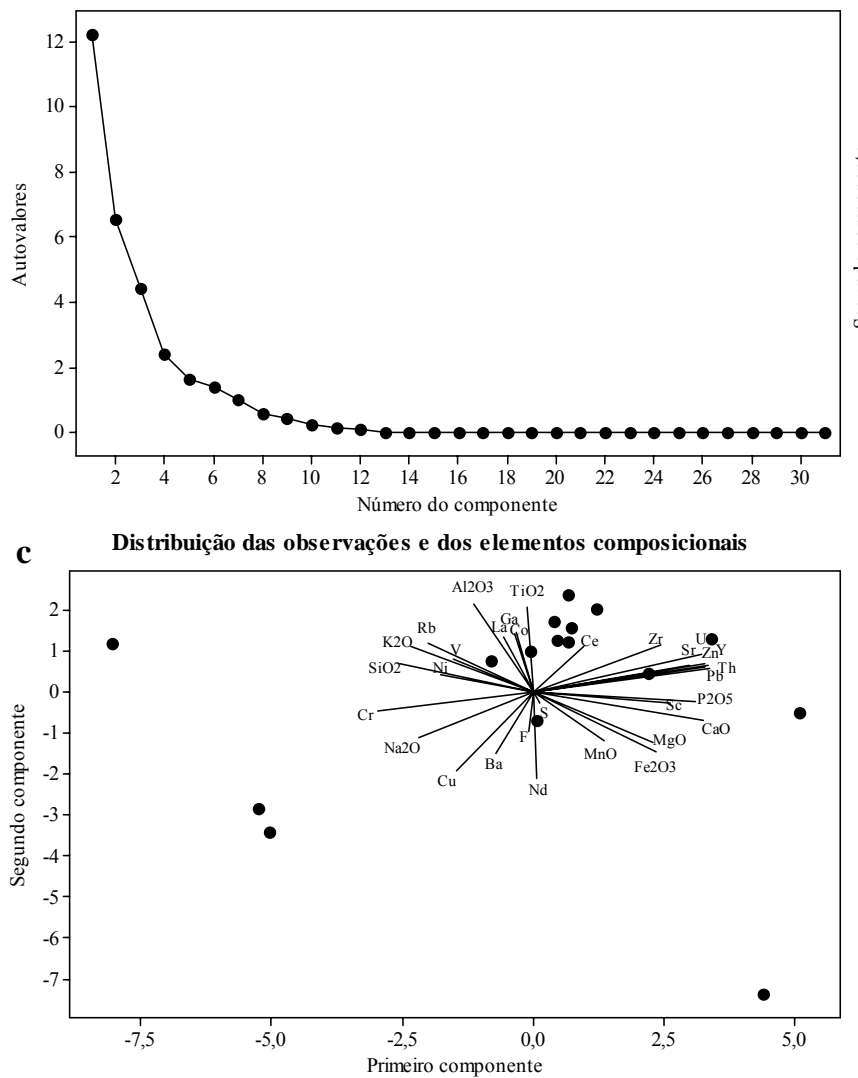

b Distribuição dos elementos composicionais

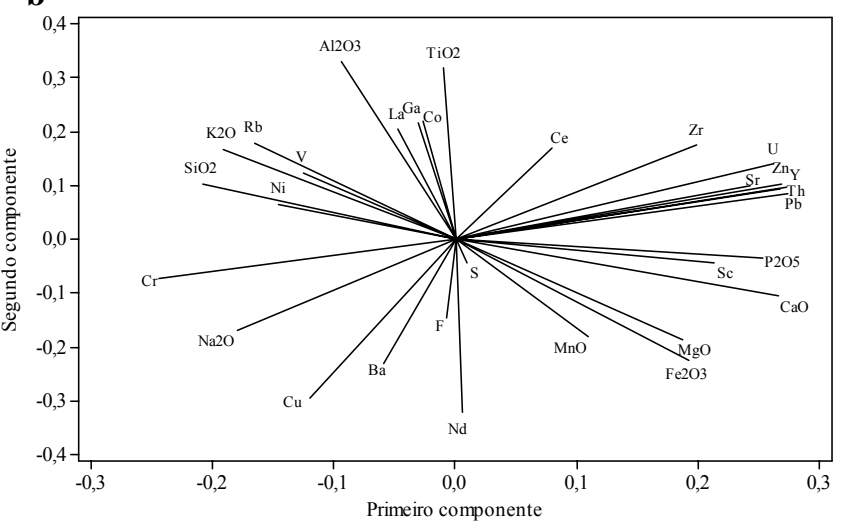

Relação entre o $1^{\circ}$ e $2^{\circ}$ componentes principais e os depósitos de micritos

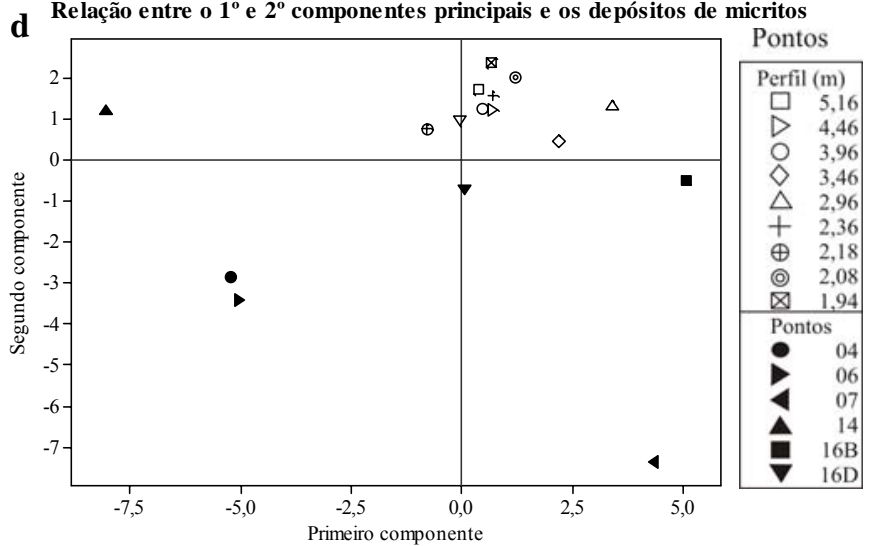

Figura 60 - Gráficos obtidos da análise multivariada dos elementos composicionais do perfil da Mineração Calcário Xaraés sem as três amostras da base e os demais pontos. a) Autovalores dos componentes principais. b) Distribuição dos elementos composicionais no $1^{\circ}$ e $2^{\circ}$ componentes principais. c) Distribuição das observações e dos elementos composicionais. d) Relação entre o $1^{\circ}$ e $2^{\circ}$ componente principal.

Os depósitos 07 e 14 são os mais distintos na análise, ambos ocorrem às margens de rios, visualmente são diferentes. $\mathrm{O}$ depósito 07 difere de todos os outros pela coloração mais amarelada, já 14 é pouco poroso e com composição faunística diferente dos demais, único a apresentar gastrópodes do gênero Megalobulimulus.

A análise de agrupamento revela três grandes grupos (Figura 61), um deles composto pelos pontos do perfil de micritos da Mineração Calcário Xaraés, um segundo contendo os pontos $16 \mathrm{~B}, 16 \mathrm{D}$ e $07 \mathrm{~A}$, também agrupados no quadrante positivo para o $1^{\circ}$ componente e 
negativo para o segundo, com outras características em comum já citadas. Um terceiro grupo é integrado por 04, 06 e 14 que também acompanham a disposição do agrupamento na análise de componentes principais (Figura $60 \mathrm{~d}$ ).

Tabela 10 - 12 primeiros componentes principais gerados da análise multivariada dos micritos do perfil da Mineração Calcário Xaraés sem os três pontos da base e os demais depósitos estudados.

\begin{tabular}{|c|c|c|c|c|c|c|c|c|c|c|c|c|}
\hline \multicolumn{13}{|c|}{12 primeiros componentes principais do perfil da Mineração Calcário Xaraés } \\
\hline Tariáveis & PC1 & PC2 & PC3 & PC4 & PC5 & PC6 & PC7 & PC8 & PC9 & PC10 & PC11 & PC12 \\
\hline $\mathrm{SiO} 2$ & & & & & & & & & & & & \\
\hline $\mathrm{A} 12 \mathrm{O} 3$ & $-0,094$ & & & & & & & & 0,047 & & & 038 \\
\hline $\mathrm{MnO}$ & 0,110 & $-0,181$ & 0,046 & $-0,470$ & $-0,182$ & $-0,132$ & $-0,029$ & & 101 & & & 0,207 \\
\hline $\mathrm{MgO}$ & 0,187 & $-0,1$ & & & & & $-0,016$ & & 0,162 & $-0,102$ & & 0,028 \\
\hline $\mathrm{CaO}$ & 0,266 & $-0,106$ & 0,102 & 0,009 & 0,033 & 0,065 & $-0,012$ & $-0,130$ & 0,013 & 0,020 & 34 & $-0,062$ \\
\hline $\mathrm{Na} 2 \mathrm{O}$ & $-0,180$ & $-0,171$ & 0,119 & 0,050 & 0,411 & $-0,207$ & 0,021 & 0,056 & $-0,058$ & $-0,124$ & & $-0,109$ \\
\hline $\mathrm{K} 2 \mathrm{O}$ & $-0,192$ & & $-0,155$ & & $-0,063$ & & 0,099 & & 0,464 & & & $-0,118$ \\
\hline $\mathrm{TiO} 2$ & & & & & & & & & & & & 0,102 \\
\hline $\mathrm{P} 2 \mathrm{O} 5$ & 0,254 & $-0,034$ & 0 , & 0,157 & 0,137 & 0,078 & $-0,037$ & $-0,058$ & $-0,021$ & $-0,021$ & 29 & $-0,379$ \\
\hline $\mathrm{Fe} 2 \mathrm{O} 3$ & 0,192 & $-0,225$ & 0,193 & $-0,115$ & 0,025 & 0,012 & $-0,020$ & 0,012 & $-0,183$ & 0,052 & $-0,017$ & 0,215 \\
\hline $\mathrm{Ba}$ & $-0,058$ & $-0,232$ & & & & & $-0,014$ & & & & & $-0,006$ \\
\hline $\mathrm{Ce}$ & & & & & & & & & & & & 0,047 \\
\hline Co & $-0,026$ & 0,221 & 0,3 & $-0,139$ & 0,018 & -0 & $-0,161$ & & $-0,065$ & & & 0,016 \\
\hline $\mathrm{Cr}$ & $-0,244$ & $-0,072$ & 0,025 & 0,067 & 0,291 & $-0,200$ & 0,114 & & $-0,003$ & $-0,139$ & $-0,018$ & $-0,056$ \\
\hline $\mathrm{Cu}$ & $-0,120$ & $-0,295$ & 0,0 & & $-0,235$ & $-0,074$ & 0,032 & & 0,446 & & & 0,119 \\
\hline $\mathrm{F}$ & & & & & & & & & & & & \\
\hline $\mathrm{Ga}$ & $-0,031$ & 18 & & & 17 & & & & & & & 0,020 \\
\hline $\mathrm{La}$ & $-0,047$ & 0,204 & 0,3 & $-0,123$ & 15 & $-0,024$ & $-0,166$ & & $-0,063$ & 27 & & 0,032 \\
\hline $\mathrm{Nd}$ & 0,005 & $-0,323$ & $-0,177$ & $-0,125$ & 49 & $-0,183$ & 0,209 & & $-0,156$ & -0 & & $-0,024$ \\
\hline $\mathrm{Ni}$ & & & & & & & & & & & & \\
\hline $\mathrm{Pb}$ & & & & & & & & & & & & $-0,127$ \\
\hline $\mathrm{Rb}$ & $-0,165$ & 80 & $-0,2$ & $-0,088$ & $-0,308$ & 88 & 0,000 & & $-0,234$ & $-0,285$ & & $-0,248$ \\
\hline $\mathrm{S}$ & 0,010 & $-0,044$ & $-0,3$ & 0,016 & 0,264 & $-0,328$ & $-0,551$ & & 0,009 & $-0,009$ & $-0,023$ & $-0,104$ \\
\hline $\mathrm{Sc}$ & & & & & & & & & & & & $-0,033$ \\
\hline $\mathrm{Sr}$ & 0,243 & & $-0,043$ & $-0,275$ & & & & & & & & $-0,194$ \\
\hline Th & 0,273 & 0,098 & $-0,043$ & $-0,061$ & $-0,013$ & $-0,007$ & 0,058 & 0,030 & 0,043 & 0,007 & 0,074 & $-0,184$ \\
\hline $\mathrm{U}$ & 0,263 & 0,140 & $-0,005$ & $-0,077$ & 0,031 & $-0,018$ & 0,067 & 0,035 & 0,011 & $-0,088$ & 0,029 & $-0,262$ \\
\hline V & $-0,125$ & & & & & & $-0,023$ & & & & & 0,335 \\
\hline $\mathrm{Y}$ & & & $-0,079$ & & & $-0,050$ & 0,097 & & & $-0,099$ & & 0,270 \\
\hline $\mathrm{Zn}$ & 0,269 & 0,104 & $-0,062$ & $-0,033$ & 0,032 & $-0,030$ & 0,060 & & $-0,015$ & $-0,088$ & 0,180 & 0,154 \\
\hline $\mathrm{Zr}$ & 0,199 & 0,175 & $-0,128$ & 0,224 & 0,047 & $-0,117$ & 0,100 & 0,361 & $-0,073$ & $-0,057$ & 0,070 & 0,503 \\
\hline
\end{tabular}



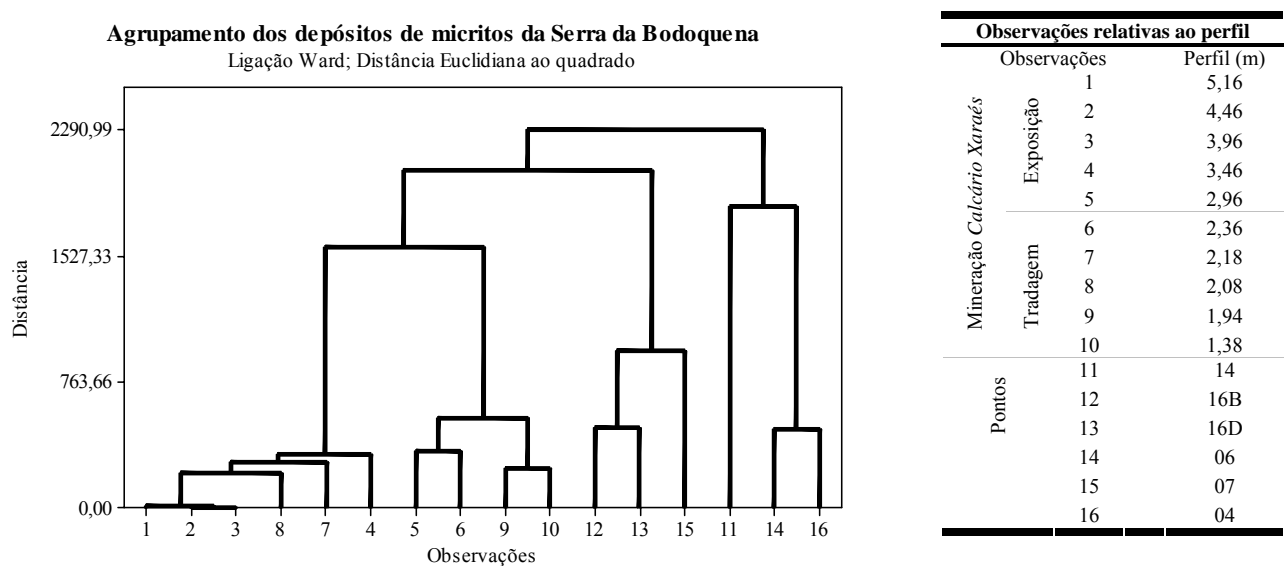

Figura 61 - Análise de agrupamento do perfil da Mineração Calcário Xaraés sem os três pontos da base e os demais pontos estudados. a) Análise de agrupamento dos micritos do perfil da Mineração Calcário Xaraés sem os três pontos da base e demais pontos estudados. b) Observações relativas aos pontos. 5,16m equivale ao topo do depósito. Exposição: amostras obtidas em porção expostas. Tradagem: amostras obtidas por coleta através de furo de trado.

\subsubsection{Considerações}

Em comparação com as tufas da Serra das Araras, estudadas por Correia (2006) e as rochas estudadas por Almeida (1965), denominadas por ele de travertinos com gastrópodes, as tufas micríticas da Serra da Bodoquena da Mineração Calcário Xaraés apresentam menor concentração de $\mathrm{SiO}_{2}$, semelhantes às rochas descritas como tufo calcário com vegetais fósseis por Almeida (1965). Em relação aos demais óxidos, os depósitos possuem aproximadamente mesma composição.

A composição dos óxidos também se mostrou semelhante aos demais tipos de tufas da Serra da Bodoquena, segundo resultados de Oliveira (2009). Esta característica corrobora com a hipótese de que as tufas micríticas são dissolvidas pelas águas fornecendo carbonatos para a formação das tufas atuais.

Os resultados das análises de agrupamento e de componentes principais das amostras da Mineração Calcário Xaraés, não são correlacionáveis entre si, não demonstrando grandes semelhanças entre os pontos. A homogeneidade dos micritos da Mineração Calcário Xaraés é evidenciada quando os dados são analisados em conjunto com os dos demais depósitos de micritos da região.

Os depósitos de micritos 04, 06 e 14 contêm maiores teores de $\mathrm{SiO}_{2}, \mathrm{Al}_{2} \mathrm{O}_{3}, \mathrm{TiO}_{2}$ e $\mathrm{Fe}_{2} \mathrm{O}_{3}$, e menores de $\mathrm{CaO}$. São depósitos sob a ação mais intensa do intemperismo, possivelmente agindo na dissolução do $\mathrm{CaO}$ e concentrando os demais óxidos. 
Os depósitos 04 e 06 se assemelham tanto na análise de componentes principais, quanto de agrupamento, provavelmente pertencem ao mesmo depósito. Da mesma forma ocorre com 16B e 16D, mas com pouca alteração na análise de componentes principais, pois possuem diferentes graus de intemperismo, modificando os resultados.

Os depósitos 07 e 14 são os mais distintos dos micritos. Os micritos do depósito 07 possuem $100 \%$ de carbonatos e baixíssimos teores de outros óxidos, tem coloração diferente e conchas intensamente intemperizadas. O depósito 14 apresenta maior concentração de $\mathrm{SiO} 2$, cerca de $35 \%$, e menor de $\mathrm{CaO}$, cerca de $25 \%$, possui coloração cinza escura e presença de gastrópodes pulmonados terrestres do gênero Megalobulimulus. Estes depósitos provavelmente representam paleoambiente distinto dos demais.

5.4. Análise de isótopos estáveis

O perfil da Mineração Calcário Xaraés, obtido através de amostras coletadas em furo de trado, apresenta valores de $\delta^{13} \mathrm{C}_{\mathrm{V} \text {-PDB }}$ que variam entre $-3,225$ e $-7,766 \%$. Os menores valores representam a base do depósito, não micrítica, diferenciada previamente pela análise multivariada dos elementos químicos e óxidos. Considerando apenas a porção puramente carbonática, que ocorre na porção superior do depósito, os valores variam de $-6,535$ a -7,766 $\%$ (Tabela 11).

Tabela 11 - Isótopos do perfil (profundidade em m) da Mineração Calcário Xaraés. Resultados para isótopo de carbono e oxigênio obtidos de micritos e de gastrópodes do gênero Pomacea. Exposição: amostras obtidas em porção expostas. Tradagem: amostras obtidas por coleta através de furo de trado.

\begin{tabular}{|c|c|c|c|c|c|}
\hline \multicolumn{6}{|c|}{ Isótopos das amostras do perfil da Mineração Calcário Xaraés } \\
\hline \multirow{2}{*}{\multicolumn{2}{|c|}{ Perfil (m) }} & \multicolumn{2}{|c|}{ Micrito } & \multicolumn{2}{|c|}{ Pomacea } \\
\hline & & $\delta^{13} \mathrm{C}_{\mathrm{V}-\mathrm{PDB}}{ }^{0} / 00$ & $\delta^{18} \mathrm{O}_{\mathrm{V}-\mathrm{PDB}}{ }^{0} / 00$ & $\delta^{13} \mathrm{C}_{\mathrm{V}-\mathrm{PDB}}{ }^{0} / 00$ & $\delta^{18} \mathrm{O}_{\mathrm{V}-\mathrm{PDB}}{ }^{0} / 00$ \\
\hline \multirow{5}{*}{ 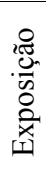 } & 5,16 (topo) & $-7,005$ & $-7,004$ & $-9,700$ & $-6,713$ \\
\hline & 4,46 & $-7,378$ & $-7,639$ & $-10,049$ & $-6,900$ \\
\hline & 3,96 & $-7,766$ & $-7,647$ & $-10,421$ & $-5,615$ \\
\hline & 3,46 & $-7,473$ & $-7,787$ & $-9,727$ & $-6,912$ \\
\hline & 2,96 & $-6,535$ & $-7,289$ & $-10,129$ & $-6,147$ \\
\hline \multirow{8}{*}{ 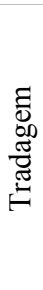 } & 2,36 & $-6,977$ & $-6,863$ & & \\
\hline & 2,18 & $-7,063$ & $-7,146$ & & \\
\hline & 2,08 & $-7,050$ & $-7,008$ & & \\
\hline & 1,94 & $-7,120$ & $-6,966$ & & \\
\hline & 1,38 & $-6,882$ & $-7,573$ & & \\
\hline & 1,06 & $-5,381$ & $-7,873$ & & \\
\hline & 0,51 & $-3,540$ & $-8,526$ & & \\
\hline & 0,01 (base) & $-3,225$ & $-8,418$ & & \\
\hline
\end{tabular}


Para $\delta^{18} \mathrm{O}_{\mathrm{V}-\mathrm{PDB}}$ a base do depósito da Mineração, de 0,01 a $1,06 \mathrm{~m}$, apresenta os maiores valores, $-3,2 \mathrm{a}-5,3 \%$, dentro do intervalo observado (Tabela 11). Os demais pontos do perfil apresentam valores de $\delta^{18} \mathrm{O}_{\mathrm{V}-\mathrm{PDB}}$ entre $-7,787$ e $-6,863 \%$.

Os resultados obtidos para $\delta^{13} \mathrm{C}_{\mathrm{V}-\mathrm{PDB}}$ das conchas de gastrópodes são mais negativos, variando de $-9,700$ a $-10,421 \%$, enquanto os de $\delta^{18} \mathrm{O}_{\mathrm{V}-\mathrm{PDB}}$ são menos negativos, -5,615 a $6,912 \%$ (Tabela 11 ), do que as amostras de rochas.

A distribuição de $\delta^{13} \mathrm{C}_{\mathrm{V}-\mathrm{PDB}}$ (Figura 62) possui tendência de aumento da negatividade, de -3 para -8 da base para o topo, refletindo aumento da influência da matéria orgânica do solo (Andrews, 2006). Este processo é facilitado pela presença da água, mostrando que não houve evaporação completa do corpo de água ao longo do perfil

No caso do $\delta^{18} \mathrm{O}_{\mathrm{V}-\mathrm{PDB}}$ (Figura 62) há tendência de redução da negatividade em direção ao topo até $2,4 \mathrm{~m}$, refletindo a redução do processo evaporítico. A partir deste ponto há aumento da negatividade, mostrando a volta deste processo. No topo do depósito o valor fica menos negativo novamente.

O gráfico de dispersão dos isótopos de carbono e oxigênio (Figura 63) mostra a diferença entre os três pontos que compõem a base do depósito, dos demais pontos que compõem o perfil da Mineração. A análise também mostra a diferença entre os isótopos obtidos dos micritos e dos gastrópodes.

Os valores obtidos para os isótopos de carbono e oxigênio dos gastrópodes podem ser reflexos dos efeitos vitais. Estes efeitos devem ter diversas origens, como preferência por um microhabitat dentro do ambiente, efeitos vitais ou alimentação (Keith et al, 1964).

Outra alternativa que pode explicar a diferença entre os valores para micritos e gastrópodes pode ser a baixa taxa de sedimentação do paleoambiente, aliada a baixa taxa de alteração das conchas, que permaneceriam no meio ambiente por longos períodos, marcando isotopicamente o ambiente de vida, sendo completamente soterradas em uma situação ambiental nova.

Os isótopos de carbono para os demais depósitos estudados apresentam-se dentro de um intervalo próximo ao observado na Mineração Calcário Xaraés, entre -6,669 e - 8,610\% do mesmo modo os resultados obtidos para os isótopos de oxigênio permaneceram dentro do intervalo já observado (Tabela 12). 


\section{Isótopos de Carbono e Oxigênio da Mineração Calcário Xaraés}

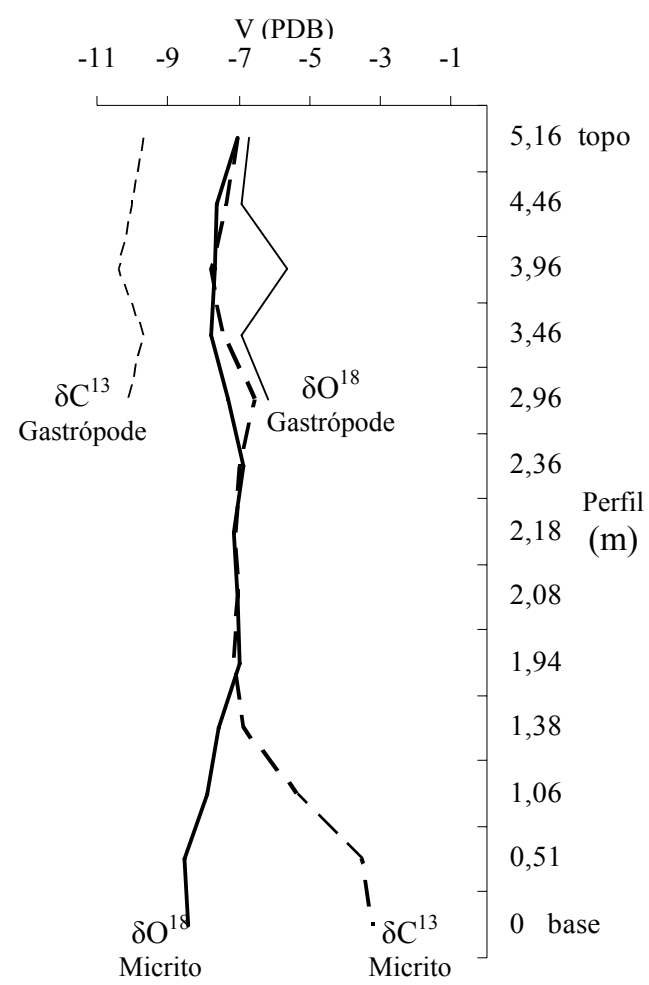

Figura 62 - Isótopos de Carbono e Oxigênio da Mineração Calcário Xaraés.

Isótopos de Carbono e Oxigênio da Mineração Calcário Xaraés

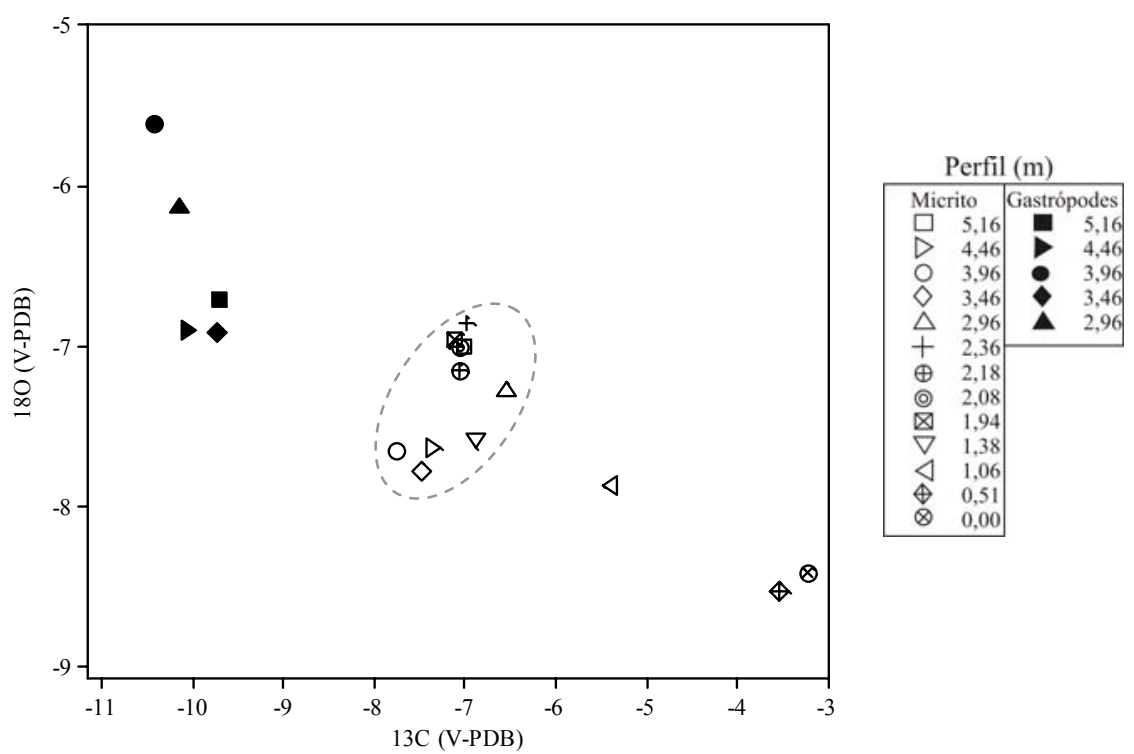

Figura 63 - Isótopos de Carbono e Oxigênio do perfil da Mineração Calcário Xaraés. Resultados de isótopos de carbono e oxigênio para análise em micritos e em gastrópodes. A elipse marca os micritos com exceção da base. Os gastrópodes analisados foram coletados no perfil de acordo com a legenda. A base do depósito é representada em $0 \mathrm{~m}$. 
Tabela 12 - Resultados para isótopo de carbono e oxigênio obtidos de micritos, gastrópodes e bivalves em amostras dos demais depósitos estudados.

\begin{tabular}{|c|c|c|c|c|c|}
\hline \multicolumn{6}{|c|}{ Isótopos dos demais pontos estudados } \\
\hline \multirow[b]{2}{*}{ Pontos } & \multicolumn{2}{|c|}{ Micrito } & \multicolumn{3}{|c|}{ Molusco } \\
\hline & $\delta^{13} \mathrm{C}_{\mathrm{V}-\mathrm{PDB}}{ }^{0} / 00$ & $\delta^{18} \mathrm{O}_{\mathrm{V}-\mathrm{PDB}}{ }^{0} / 00$ & Classificação & $\delta^{13} \mathrm{C}_{\mathrm{V}-\mathrm{PDB}}{ }^{0} / 00$ & $\delta^{18} \mathrm{O}_{\mathrm{V}-\mathrm{PDB}}{ }^{0} / 00$ \\
\hline 04 & $-6,669$ & $-7,175$ & & $-7,797$ & $-6,588$ \\
\hline 06 & $-7,012$ & $-7,341$ & Pomacea & $-9,050$ & $-6,622$ \\
\hline 07 & $-3,249$ & $-5,944$ & & $-9,406$ & $-5,966$ \\
\hline 14 & $-8,610$ & $-7,086$ & Megalobulimulus & $-11,522$ & $-5,129$ \\
\hline $16 \mathrm{~B}$ & $-7,022$ & $-7,090$ & Pomacea & $-8,960$ & $-6,642$ \\
\hline $16 \mathrm{D}$ & $-7,330$ & $-6,835$ & - & - & - \\
\hline 06 & - & - & Bivalve & $-5,409$ & $-4,806$ \\
\hline
\end{tabular}

O ponto 07, micrito depositado às margens do Rio Seputa (Norte de Bonito, MS), é diferente dos demais depósitos, sendo possivelmente alterado pelo intemperismo. Os isótopos da concha analisada (Tabela 12) apresentam valores dentro do intervalo dos demais depósitos, sugerindo que os resultados a partir de conchas não revelam concentrações isotópicas ambientais, e sim características particulares dos moluscos analisados.

A análise em conchas de moluscos para o gênero Pomacea indica valores dentro do intervalo $-7,797$ e $-9,406 \%$ de $\delta^{13} \mathrm{C}_{\mathrm{V}-\mathrm{PDB}}$, semelhantes aos observados na Mineração Calcário Xaraés. Para outros gêneros os valores variam, provavelmente em razão do ambiente de vida do animal e alimentação.

Para Megalobulimulus, ponto 14, gênero de molusco terrestre, os valores de isótopos de carbono são mais negativos e de isótopos de oxigênio menos negativos. Já para o bivalve analisado, de hábitos aquáticos com influência de correntes, os valores de isótopos de carbono e oxigênio são menos negativos em relação à Pomacea, gênero tolerante a ambientes que variam de úmidos a aquáticos (Tabela 12).

A Figura 64 mostra estas diferenças. Os resultados para as análises em micritos se agrupam, assim como para os gastrópodes do gênero Pomacea, com exceção do depósito 07, do Rio Seputa, tanto para Pomacea, como para os micritos. A análise em bivalve, do depósito 06 e em Megalobulimulus, do depósito 14A, também são diferentes.

O resultado para o bivalve demonstra possivelmente um ambiente mais fluvial, enquanto Megalobulimulus um ambiente mais terrestre, refletindo os hábitos destes moluscos.

Quando os depósitos de micritos são observados em um único gráfico (Figura 65), os símbolos aparecem agrupados em três conjuntos: a base da Mineração Calcário Xaraés, contendo argilominerais em maior quantidade, micritos, com e sem a presença de moluscos, e valores para amostras de gastrópodes do gênero Pomacea. 
Comparação dos isótopos de Carbono e Oxigênio dos depósitos da Serra da Bodoquena

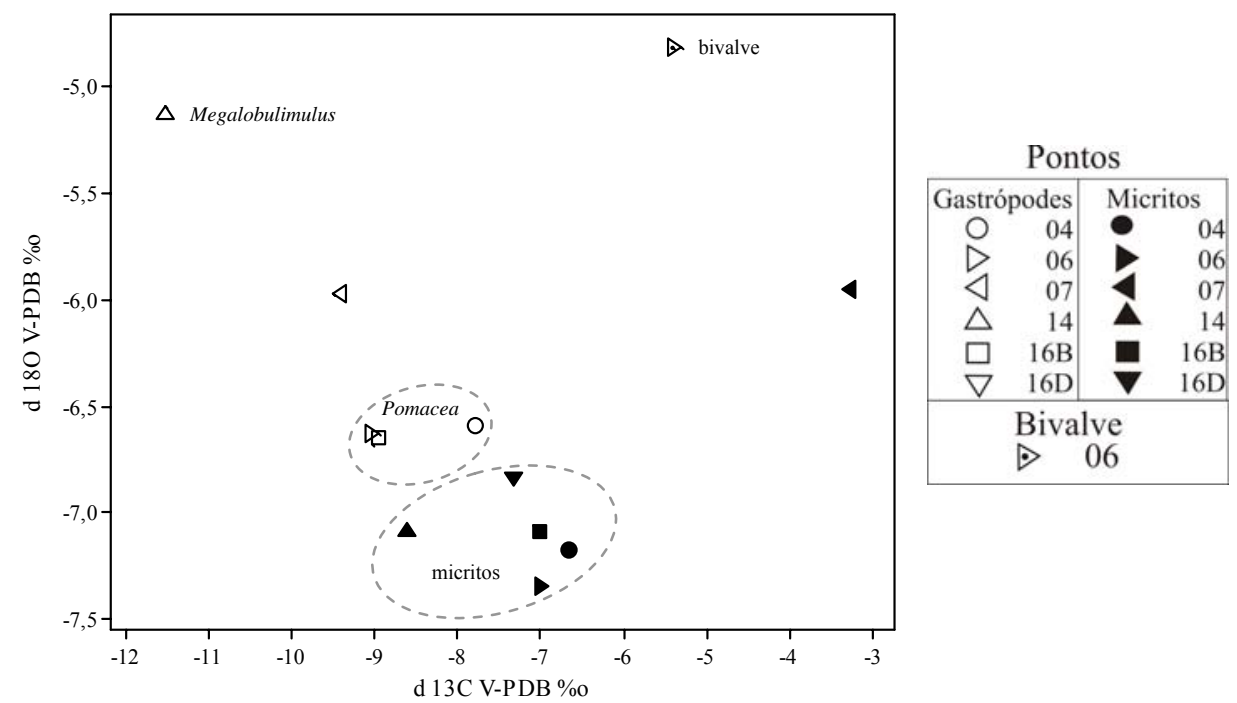

Figura 64 - Comparação dos isótopos de carbono e Oxigênio dos depósitos da Serra da Bodoquena. Resultados de isótopos de carbono e oxigênio para análise em micritos e moluscos.

Apenas três das amostras analisadas não pertencem a estes conjuntos. $\mathrm{O}$ depósito 07 apresenta valores sem nenhuma relação com os demais micritos. É um depósito de granulometria mais fina, e menos inconsolidado que os demais, sendo provavelmente formado em um paleoambiente mais estável, que permitiria maior crescimento vegetacional, justificando os valores menos negativos de $\delta^{13} \mathrm{C}_{\mathrm{V}-\mathrm{PDB}} \%$. Também pode haver intensa modificação pelo intemperismo, o que justificaria os resultados das relações isotópicas.

O gastrópode e a amostra de micrito deste depósito apresentam o mesmo valor de $\delta^{18} \mathrm{O}_{\mathrm{V}-\mathrm{PDB}} \%$. Considerando que os gastrópodes encontrados neste depósito estavam muito alterados em relação aos demais depósitos, é possível que tenha ocorrido modificação em sua composição química, alterando os resultados isotópicos.

O resultado para a análise em conchas do bivalve do ponto 06 , também está excluído dos conjuntos. É possível que a análise feita em bivalves seja diferente, não somente pela mudança ambiental, mas pelo efeito vital do animal.

Outro resultado excluído do conjunto é a análise do gastrópode presente no depósito 04. É provável que este indivíduo seja mais jovem que o depósito, sendo resultado de um processo de retrabalhamento do micrito, pois está muito próximo ao leito do Rio Mimoso, de alto fluxo de água, justificando resultado diferente dos demais. 
Não há diferença, para os resultados de isótopos de carbono e oxigênio, entre micritos com ou sem moluscos. O ponto que mais se diferencia daqueles agrupados em "micritos" na Figura 65, é o ponto 14. A diferença está nos valores de $\delta^{13} \mathrm{C}_{\mathrm{V}-\mathrm{PDB}} \%$, representando maior influência de matéria orgânica do solo.

O gastrópode analisado no ponto 14 é o Megalobulimulus, molusco de hábitos terrestres. Sua presença indica um ambiente com menor volume de água, por exemplo, a margem de um lago, que aumentaria a oxigenação do meio, resultando maior ciclagem dos nutrientes e menor valor de $\delta^{13} \mathrm{C}_{\mathrm{V}-\mathrm{PDB}} \%$.

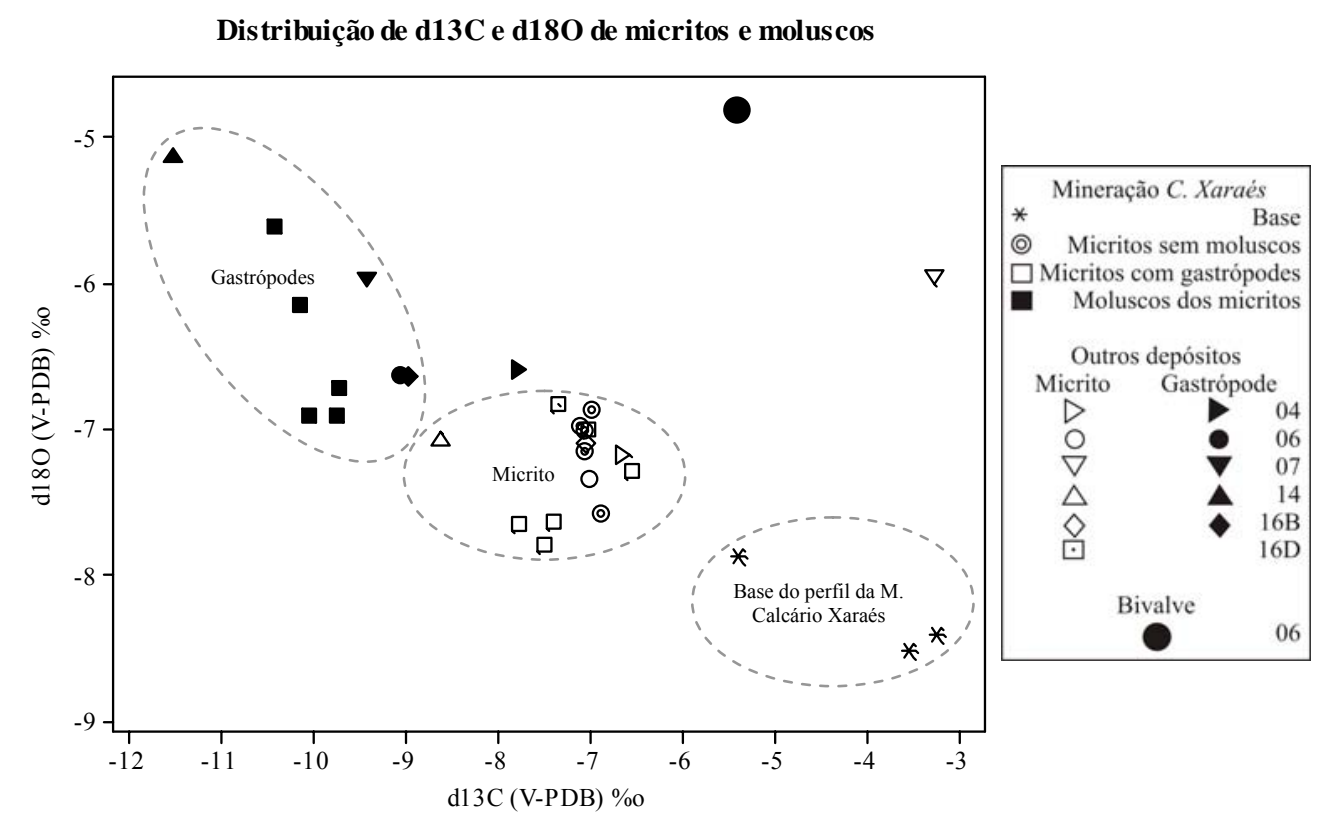

Figura 65 - Distribuição de $\delta^{13} \mathrm{C}_{\mathrm{V}-\mathrm{PDB}} \%$ e $\delta^{18} \mathrm{O}_{\mathrm{V}-\mathrm{PDB}} \%$ para os depósitos micríticos e moluscos encontrados nestes calcários. 


\section{RESULTADOS PALEONTOLÓGICOS}

6.1. Identificação dos moluscos

As identificações dos gastrópodes encontrados em campo estão anotadas na Tabela 13. Os moluscos que não se fragmentaram pelo manuseio foram depositados na Coleção Científica de Fósseis do Instituto de Geociências da Universidade de São Paulo (Anexo E), não foram depositados os moluscos considerados atuais. Nos pontos 02 e $12 \mathrm{C}$ e D os gastrópodes são encontrados sob a superfície do solo, e apresentam conchas pouco intemperizadas, indicando morte recente. Nos demais pontos, 07, 12F, 13, 16 e 17, são encontrados gastrópodes tanto incrustados nos micritos, quanto recentemente depositados.

Estas conchas recentemente depositadas indicam que tais gêneros de gastrópodes ainda vivem na região, como Pomacea e Biomphalaria (Figura 66 A, B, C e D). Nos pontos 01, 04 e 15 as conchas estão presentes apenas incrustadas nos micritos, mas no ponto 15 existem indivíduos viventes, já que no ambiente há disponibilidade de alimentação (Tabela $13)$.

Tabela 13 - Moluscos identificados durante as coletas na Serra da Bodoquena.

\begin{tabular}{|c|c|c|c|c|c|c|c|c|c|c|c|}
\hline \multicolumn{12}{|c|}{ Moluscos identificados na Serra da Bodoquena } \\
\hline & \multicolumn{9}{|c|}{ Gastrópodes } & \multicolumn{2}{|c|}{ Bivalves } \\
\hline Pontos & 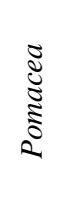 & 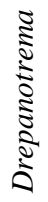 & 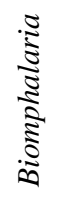 & 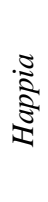 & 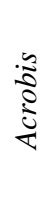 & 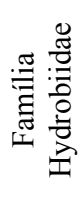 & 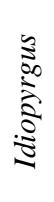 & 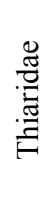 & 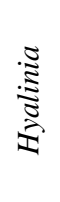 & $\begin{array}{l}\frac{\tilde{0}}{0} \\
\frac{0}{5} \\
\tilde{a}\end{array}$ & 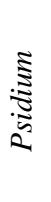 \\
\hline 01 & 3 & & & & & & & & & & \\
\hline 02 & 1 & & & & & & 1 & 4 & & & \\
\hline 04 & 6 & & & & & 4 & & & & 4 & 1 \\
\hline $07 \mathrm{C}$ & 3 & & & & & & & & & & \\
\hline 07E & 2 & & & & & & & & & & \\
\hline $12 \mathrm{C}$ & 2 & & & & & & & & & & \\
\hline $12 \mathrm{D}$ & 4 & & & & & & & & & & \\
\hline $12 \mathrm{~F}$ & 4 & & 8 & & & 18 & & & 1 & & \\
\hline 13 & 3 & & 7 & 3 & 1 & 7 & 1 & & & & 1 \\
\hline $15 \mathrm{~A}$ & 8 & & 15 & & & 8 & 5 & & & & 1 \\
\hline $16 \mathrm{~A}$ & 6 & 1 & 10 & & & & & & & & \\
\hline 17 & 11 & & 12 & & & & 5 & & & & \\
\hline
\end{tabular}



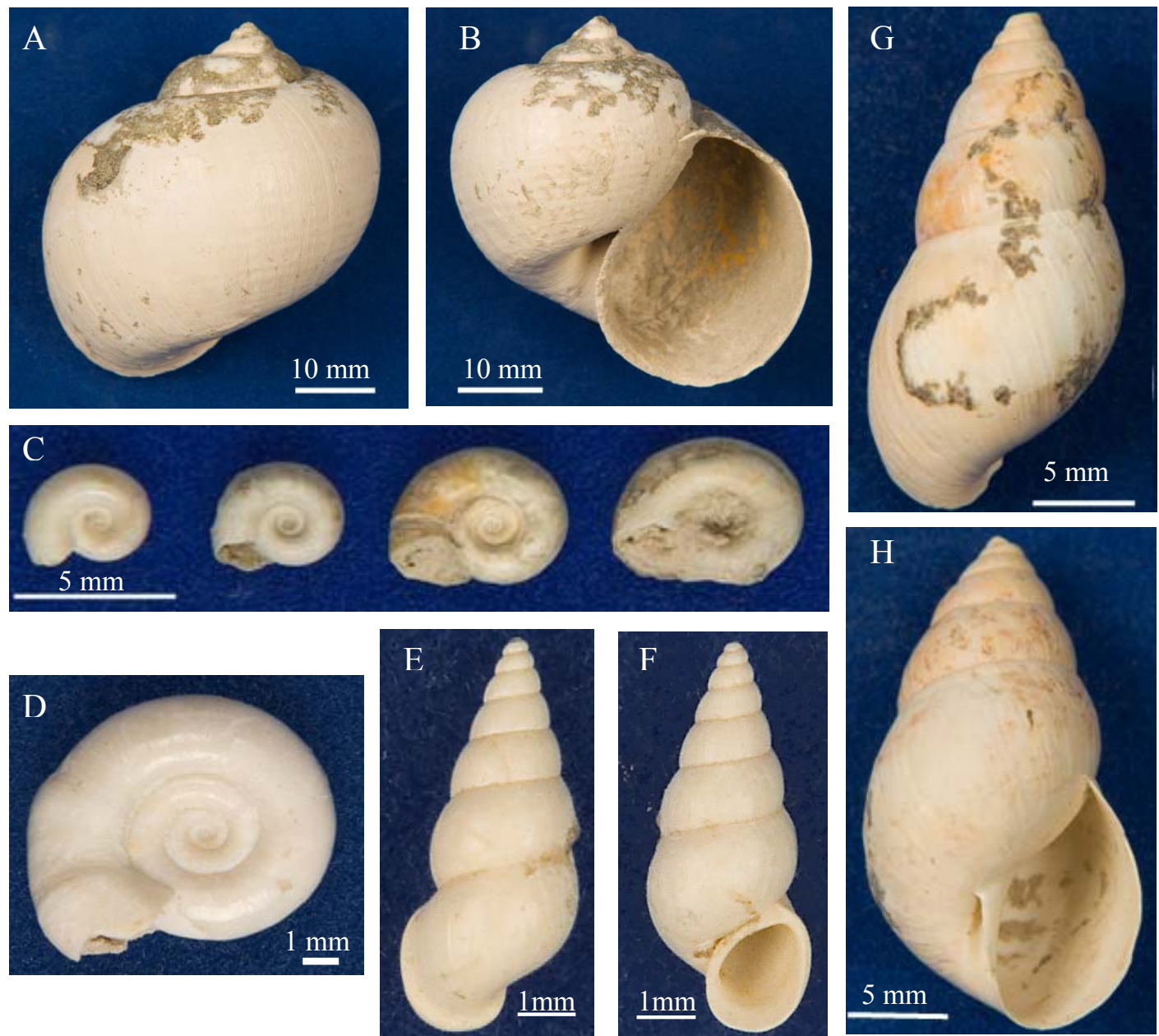

Figura 66 - Gastrópodes encontrados na Mineração Calcário Xaraés. A, B) Pomacea. C, D) Biomphalaria. E, F) Idiopyrgus. G, H) Bulimulus.

O gênero Pomacea (Figura 66 A e B) é identificado em todos os pontos coletados e em maior concentração naqueles em que apresentam indivíduos viventes. Biomphalaria (Figura 66 C e D) foi registrado em 12, 13, 15, 16 e 17, e Idiopyrgus (Figura 66 E e F) em 02, 12, 13, 15 e 17 (Tabela 13).

Os indivíduos da Família Hydrobiidae são muito semelhantes a Idiopyrgus, e as vezes não podem ser distinguidos, eles são possivelmente do gênero Littoridina. Em alguns casos foram considerados um único grupo. Eles aparecem nos pontos 04, 12F, 13 e 15A (Tabela 13).

Os demais gêneros são pouco representativos nos pontos amostrados. No ponto 02 ocorre um indivíduo da Família Thiaridae, que não foi possível identificar até gênero. No ponto $12 \mathrm{~F}$ é identificado um indivíduo de Hyalinia. 
O depósito do ponto 13 contém os gêneros Happia e Acrobis, além do bivalve Psidium, também identificado no ponto 15 (Figura 67 d,e,f). No ponto 16 ocorre o gênero Drepanotrema (Figura 67 c).

Utida et al. (2007) identificaram na Mineração Calcário Xaraés as espécies Pomacea canaliculata, Pomacea semperi, Idiopyrgus souleyetianus e o gênero Biomphalaria.

Em $100 \mathrm{~g}$ de sedimento analisados da Mineração Calcário Xaraés, são encontrados gastrópodes apenas na porção exposta da lavra, entre os pontos 5,16 e 2,96 (Tabela 14). Utida et al. (2007) também identificaram na Mineração Calcário Xaraés o gênero Bulimulus (Figura $66 \mathrm{G}$ e H).

A concentração de Pomacea é maior nas amostras de 4,46 a 3,96m, representada por 3, 7 e 6 indivíduos respectivamente. O gênero desaparece em 3,46m, e reaparece com 1 indivíduo em 2,96m. Nestas analises o gênero Pomacea não está presente nos depósitos $04 \mathrm{e}$ em 16B os fragmentos encontrados são possivelmente deste gênero, único macrogastrópode encontrado na amostra. Biomphalaria ocorre em todos os depósitos com exceção de 16B, com variação de número de indivíduos, sendo mais abundante em 06.
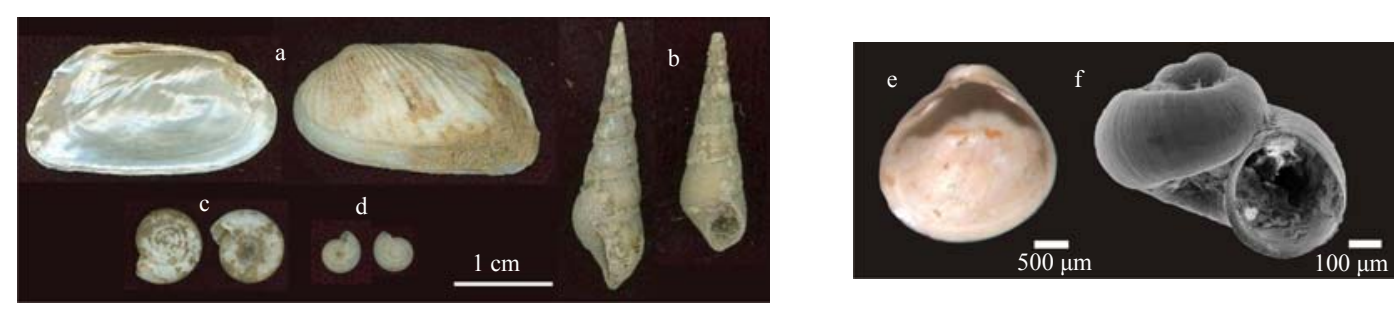

Figura 67 - Demais moluscos encontrados nos depósitos. a) Visão interna e externa de Diplodon. b) Dois indivíduos da Família Thiaridae. c) Visão dorsal e ventral de Drepanotrema. d) Visão ventral e dorsal de Happia. e) Visão interna de Psidium. f) Indivíduo do gênero Acrobis.

No perfil do depósito de micritos da Mineração Calcário Xaraés, os indivíduos da Família Hydrobiidae e/ou Idiopyrgus, aparecem com 37 indivíduos, praticamente desaparecendo nas amostras de estratos inferiores. Também é bem representada em 06, com 88 indivíduos, e apenas 15 para o ponto 04 .

Outros gêneros são pouco representativos, por exemplo, dois gêneros de bivalves, Psidium e Diplodon (Figura 67 a e e) encontrado nos pontos 04 (Tabela 13 e 14) e 06. Apesar de Diplodon ocorrer incrustado no micrito, é possível que seja atual, e tenha sido depositado posteriormente, com o retrabalhamento do micrito, pois ocorre nas margens do Rio Mimoso nos dois pontos. 
Bivalves respiram através de brânquias, com menor eficiência que os gastrópodes, pois as brânquias filtram o alimento em suspensão, além de realizarem as trocas gasosas. Em áreas bem oxigenadas realizam as trocas gasosas diretamente pela parede corporal (Ruppert \&Barnes, 1996). Por este motivo, bivalves não habitam áreas de baixo fluxo de água, como lagos, pois a oxigenação da água é reduzida, além de não haver fluxo que traga alimento em suspensão para os indivíduos filtradores. Isto fornece mais um argumento para a formação dos depósitos micríticos em ambientes alagados de baixo fluxo de água na região da Serra da Bodoquena.

No ponto 04 também são identificados os gêneros Hebetancylus e Pseudogyppy, possivelmente atuais (Tabela 14).

Tabela 14 - Moluscos identificados em 100g das amostras de micritos da Serra da Bodoquena.

\begin{tabular}{ccccccccc}
\multicolumn{8}{c}{ Moluscos identificados nos micritos da Serra da } \\
Bodoquena
\end{tabular}

Os pontos 04 e 06 representam depósitos mais diversificados em número de gêneros. Estes pontos estão muito próximos entre si e do Rio Mimoso e provavelmente, foram formados ao mesmo tempo. A presença de bivalves nestes pontos sugere a existência de fluxo de água, por isso mantêm maior diversidade, apresentando variação ambiental ao longo de sua deposição.

Pomacea é um gastrópode que se distribui em climas tropicais e subtropicais na África, Ásia, América central e do Sul. Geralmente ocupa águas lóticas e correntes de água lentas (Cowie \& Thiengo, 2003).

O gênero Pomacea não é bom indicador ambiental, já que pode se adaptar às diversas condições ambientais, desde ambientes de baixas condições hídricas até sistemas fluviais, 
além dos adultos serem tolerantes a exposição ao ar e tolerantes a variações de salinidade (Mildward de Andrade, 1981 apud Pizani et al.,2005; Cowie \& Thiengo, 2003).

Os pulmonados em geral, entre eles Biomphalaria, Drepanotrema e Acrobis, são mais comuns em áreas temporariamente alagadas e margens de sistemas aquáticos lóticos, mas podem variar de habitat anfíbio a completamente aquático (Brown et al., 1998).

Já Biomphalaria fornece informações de grande interesse, pois prefere locais temporariamente alagados, de pouca profundidade, constituindo argumento a mais para a hipótese de ambiente lacustre para os depósitos da região da Serra da Bodoquena. Segundo Schneck \& Fried (2005) indivíduos de Biomphalaria glabrata desenvolvem-se em condições ótimas em laboratório a $23^{\circ} \mathrm{C}$, sugerindo uma possível faixa de temperatura ambiental para a época de formação dos depósitos onde ocorrem indivíduos deste gênero.

Infelizmente o número de indivíduos encontrados não é suficiente para análises estatística de diversidade e tafonômica, possibilitando apenas análise qualitativa.

\subsection{Análises tafonômicas}

\subsubsection{Análise do bloco orientado em planta}

Um bloco orientado em relação ao norte, de aproximadamente $(32 \times 31,5) \times(15,5 \times$ 17) $\mathrm{x} 25,5 \mathrm{~cm}$, retirado da frente da pedreira Mineração Calcário Xaraés, ponto 01, foi estudado no laboratório, com enfoque tafonômico.

Foram analisadas 5 camadas do bloco orientado de espessuras variadas, já que foi difícil manter a proporção manualmente, a média foi de $1,5 \mathrm{~cm}$ de espessura por camada, em um total de $7 \mathrm{~cm}$ em uma área de 15,5x28cm aproximadamente (Figura 69).

O sedimento retirado foi pesado e as proporções de bioclastos foram calculadas para cada $100 \mathrm{~g}$, para comparações entre as camadas. 
A camada 1 é a menos rica em bioclastos, enquanto as camadas 2 , 3 e 4 têm proporções equivalentes de bioclastos, e a camada 5 pouco mais rica. A proporção média do total de bioclastos encontra-se no intervalo das camadas 2, 3 e 4 (Tabela 15). planta.

Tabela 15 - Características do sedimento retirado de cada camada do bloco orientado na análise em

\begin{tabular}{cccc}
\hline \multicolumn{4}{c}{ Características do bloco estudado em planta } \\
\hline Camada & Peso $(\mathrm{g})$ & $\mathrm{N}^{\circ}$ de bioclastos & $\mathrm{N}^{\circ}$ de bioclastos em 100g \\
1 & 345 & 57 & 17 \\
2 & 425 & 145 & 34 \\
3 & 720 & 260 & 36 \\
4 & 1.135 & 400 & 35 \\
5 & 865 & 403 & 47 \\
Total & 3.490 & 1.277 & Média $=34$ \\
\hline
\end{tabular}

Cerca de $20 \%$ dos bioclastos foram fragmentados durante manuseio. Foram considerados friáveis 4\% dos bioclastos (Figura 68), ou seja, o carbonato das conchas estava em processo de dissolução mais evidente, com separação em camadas.

A análise em planta mostra cerca de 90\% do empacotamento do depósito entre fraco e disperso (Figura 71 a) de acordo com classificação de Holz \& Simões (2002). Os 10\% restantes são conchas estão aglomeradas densamente apenas em porções do sedimento (Figura 68b).
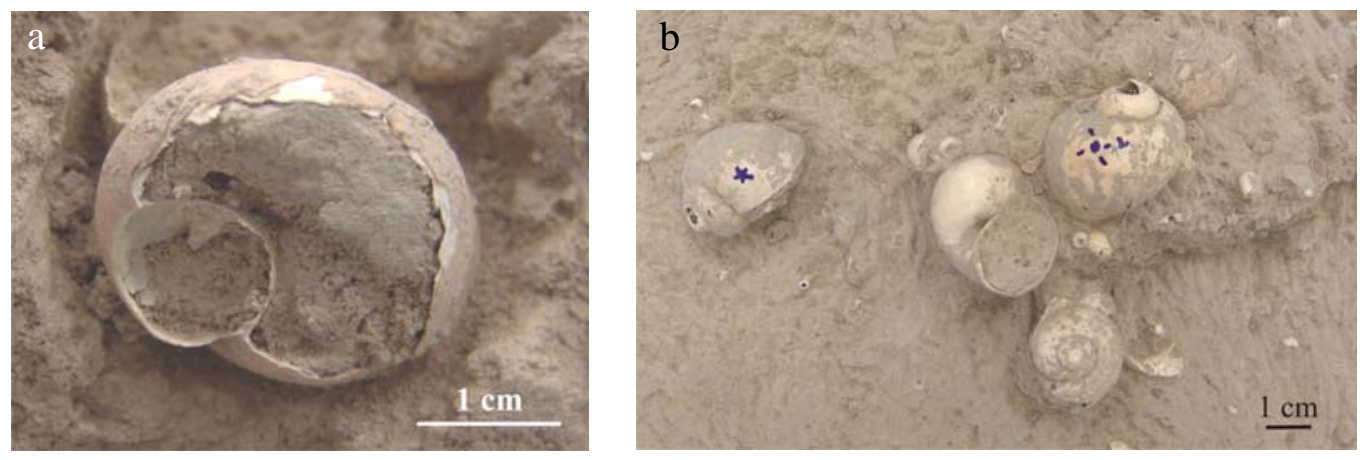

Figura 68 - a) Gastrópode do gênero Pomacea classificado como friável na análise tafonômica. Notar as camadas da concha. b) Porção da camada 4 com empacotamento de bioclastos considerado denso a direita, a esquerda empacotamento disperso. Notar também a incrustação nos gastrópodes. 

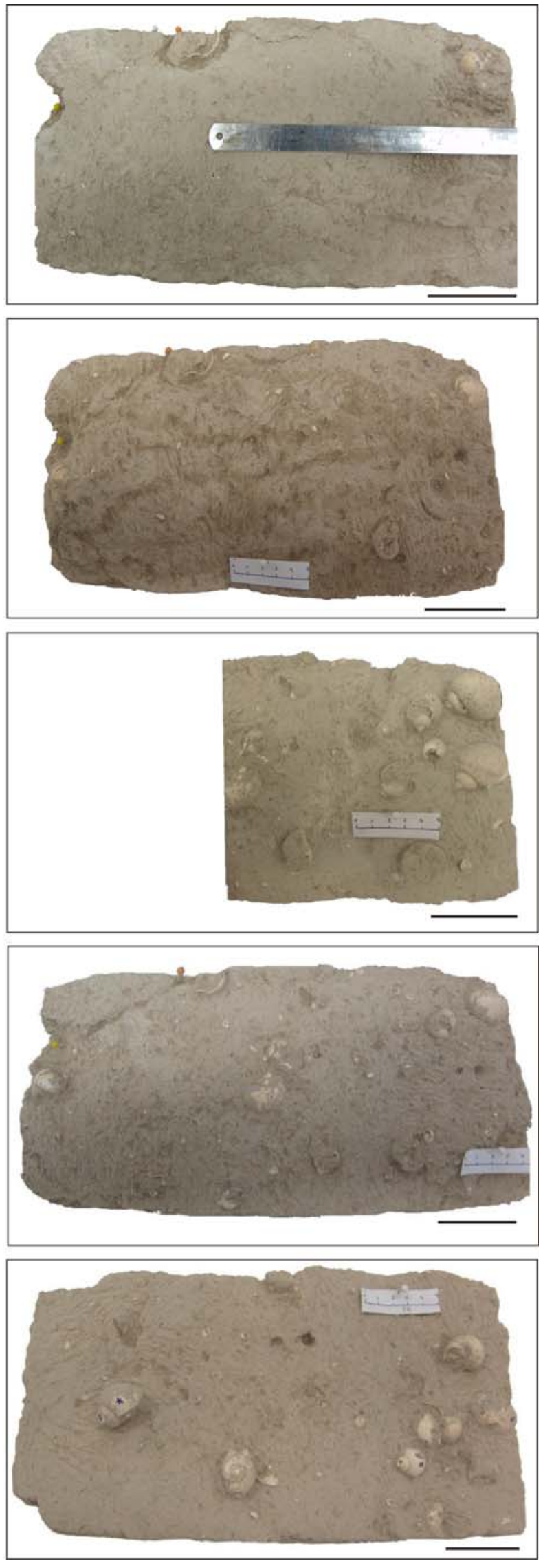

Figura 69 - Análise tafonômica em planta. Imagens das camadas analisadas do bloco orientado de micritos da Mineração Calcário Xaraés. Escala $5 \mathrm{~cm}$.

\section{Camada 1}

\section{Camada 2}

Parte da Camada 3

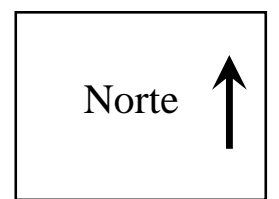

\section{Camada 4}

\section{Camada 5}


Os bioclastos são encontrados com predomínio da posição oblíqua, 30\% são concordantes e cerca de 25\% perpendiculares (Figura 71 b). $70 \%$ dos bioclastos não possuem alterações na textura, 65\% deles são esbranquiçados (Figura 70 a). Poucos indivíduos apresentaram coloração sem alterações (Figura 70 a).
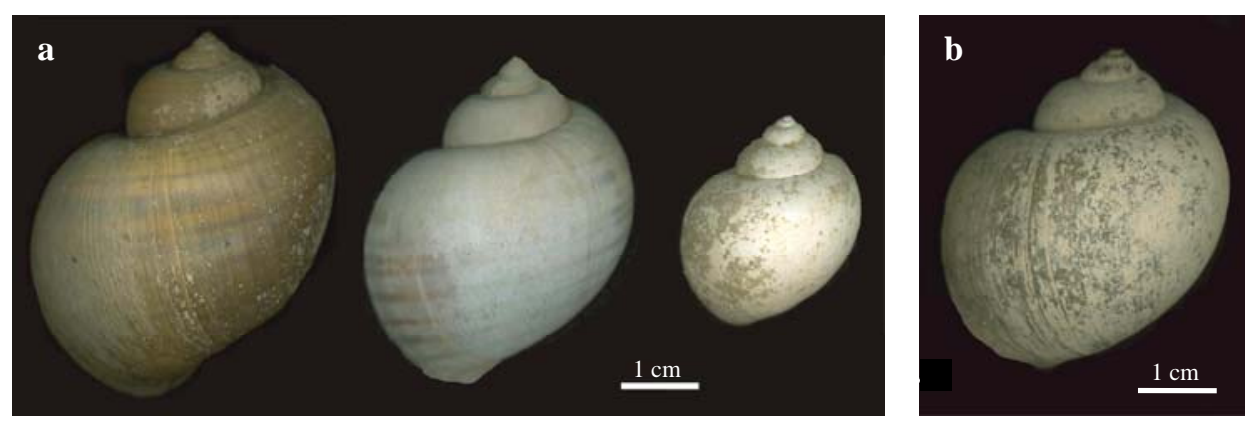

Figura 70 - Exemplos de assinaturas tafonômicas estudadas. a) A primeira concha é atual e possui coloração característica. A segunda concha, apesar de atual, esteve exposta a ações intempéricas apresentando perda de cor. A terceira concha é fóssil, coletada no ponto 04, possui algumas incrustações e está completamente branca. b) Concha atual com inscrutações carbonáticas semelhantes às encontradas nos fósseis, como a da terceira concha em a.

Em 1156 indivíduos analisados apenas 231 são classificados com algum tipo de alteração, cerca de 20\%, a maior parte deles com corrosão e abrasão (Figura 73). A incrustação observada ocorre com maior frequência nos moluscos de maior tamanho (Figura 68 b), provavelmente aqueles que ficam mais tempo expostos, permitindo que ocorra incrustação carbonática, como ocorre com qualquer material que fica fixo em contato com a água, como observado nos rios atuais (Figura 70 b e 72). A incrustação carbonática ocorre na face voltada para cima em contato com a água, e está ausente na face inferior do limbo foliar.

Dos 231 indivíduos que apresentam algum tipo de alteração cerca de 95\% estão dispersos por toda a concha. Os demais se localizam na última espiral e em menor frequência ocorrem alterações nos lábios das conchas (Figura 73).

Em 50\% dos bioclastos não há fragmentação, nos 50\% restantes, a frequência da fragmentação diminui com o aumento do intervalo de fragmentação (Figura 71 e). Quando observada a proporção do local fragmentado de acordo com o intervalo de porcentagem de fragmentação (Figura 74) as áreas mais afetadas são o ápice e a última espiral, exceto para os bioclastos fragmentados em mais de $90 \%$ de sua área, classe que apresenta distribuição mais uniforme. 
a) Empacotamento do depósito

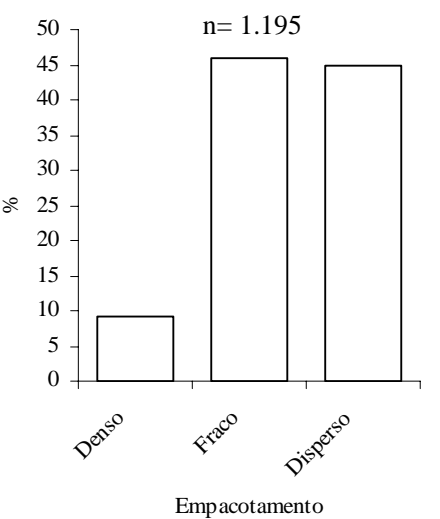

d) Coloração dos bioclastos

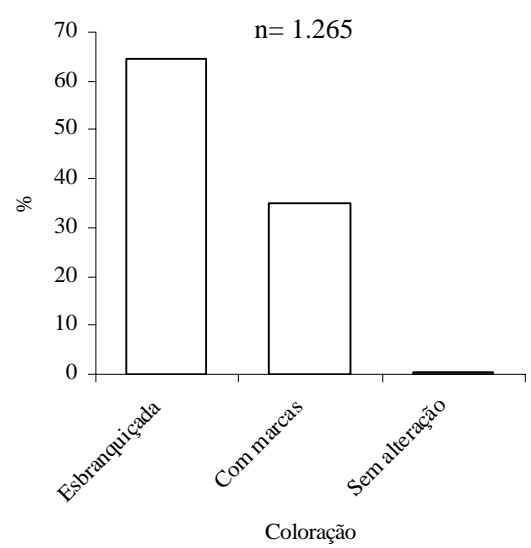

\section{b) Orientação dos bioclastos}

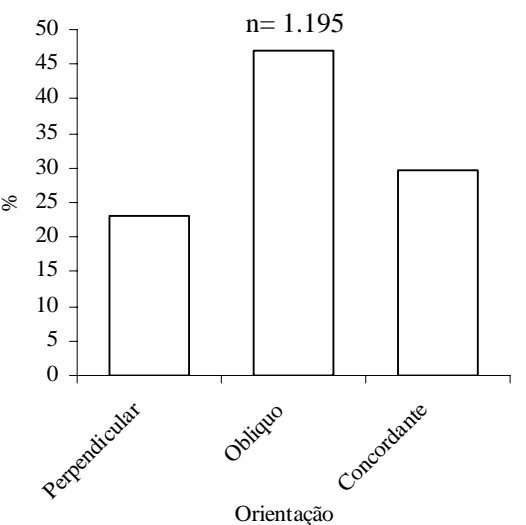

c) Textura dos bioclastos

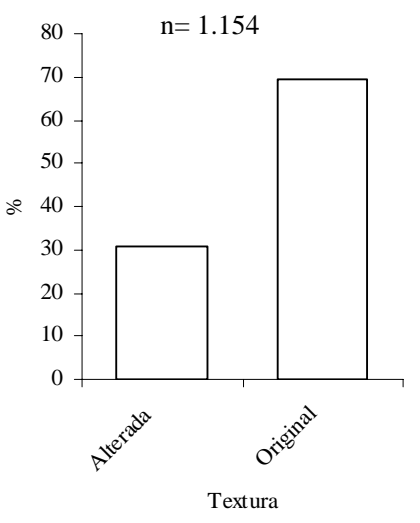

Figura 71 - Análise do bloco em planta. a) Empacotamento do depósito. b) Orientação dos bioclastos.

c) Textura dos bioclasto. d) Coloração dos bioclastos. e) Fragmentação dos bioclastos.

\section{e) Fragmentação dos bioclastos}

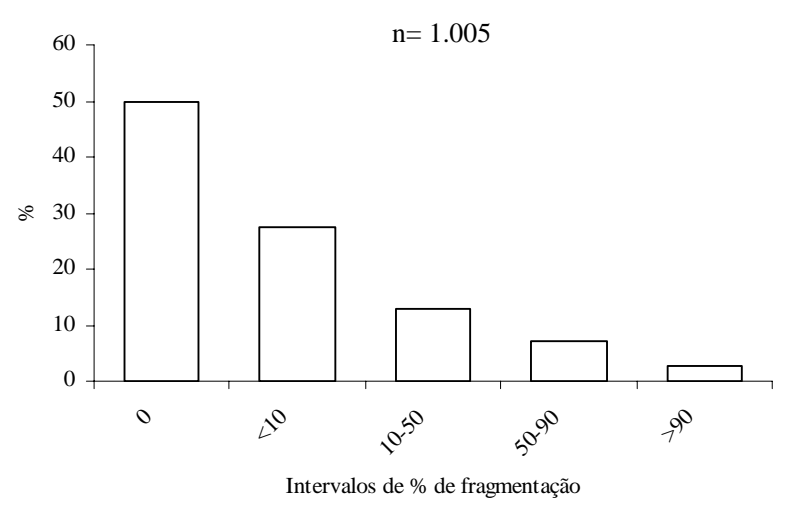

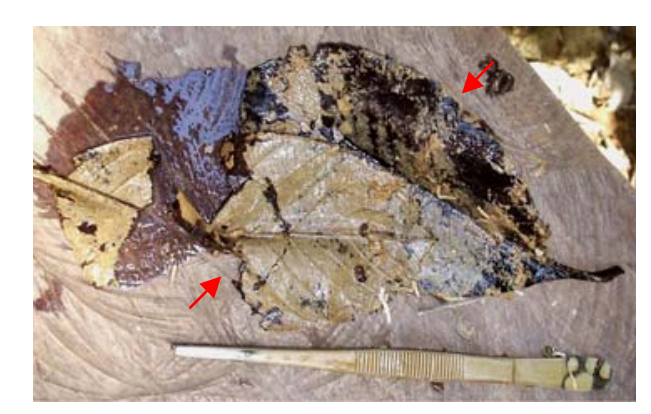

Figura 72 - Folhas com incrustação carbonática (seta inferior) e sem incrustação carbonática (seta superior), presas em troncos dentro do leito do Rio Betione, Bodoquena-MS. 


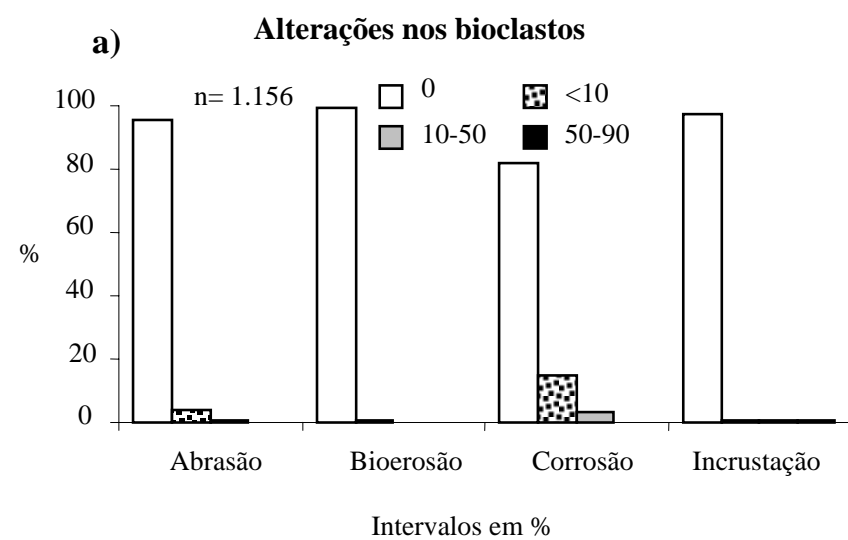

b) Posição da alteração nos
bioclastos

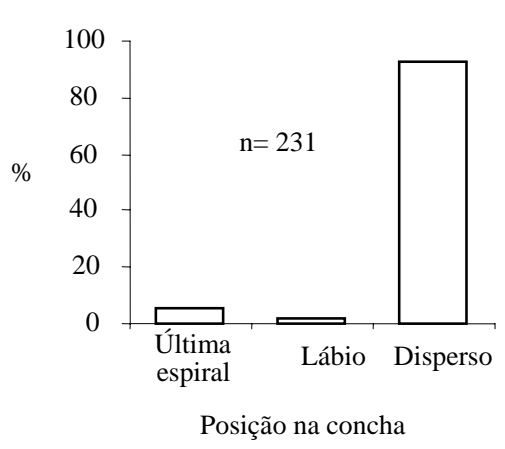

Figura 73 - Classificação de alteração dos bioclastos obtidos do bloco orientado da análise em planta. a) Alteração dos bioclastos. b) Posição da alteração nos bioclastos.

Quando observada a fragmentação de acordo com o táxon (Figura 74 b) a porcentagem de fragmentação mantém aproximadamente o mesmo padrão para os gastrópodes, com redução da frequência dos bioclastos com o aumento dos intervalos de fragmentação.

O gênero Biomphalaria mantém a melhor proporção de indivíduos não fragmentados, e menores frequências nos intervalos de fragmentação maiores. No caso dos bivalves a porcentagem não fragmentada é grande, e apresenta fragmentação menor que 10\% de área e entre 10 e 50\% com menores frequências, já que são conchas pequenas e mais espessas, portanto mais resistentes. Os demais gastrópodes apresentam aproximadamente o mesmo padrão de fragmentação (Figura 74 b).

Observando a posição de fragmentação de acordo com o táxon (Figura 74 c) todos apresentam fragmentação em áreas dispersas, no caso de Pomacea posição mais significativa em porcentagem. Para o gênero Idiopyrgus a posição de maior incidência de fragmentação é o ápice, e para os demais o lábio da concha é o local mais fragmentado.

Estes dados refletem as áreas das conchas mais sensíveis a ação do ambiente em que foram sedimentadas e dos processos pós deposicionais. Pomacea apresenta a menor frequência de indivíduos não fragmentados, é o bioclasto de maior dimensão entre os taxa, portanto, sujeito a maior tempo de exposição na interface água-sedimento. Ao contrário dos demais taxa que possuem dimensões reduzidas, sendo relativamente soterrados com maior rapidez. 


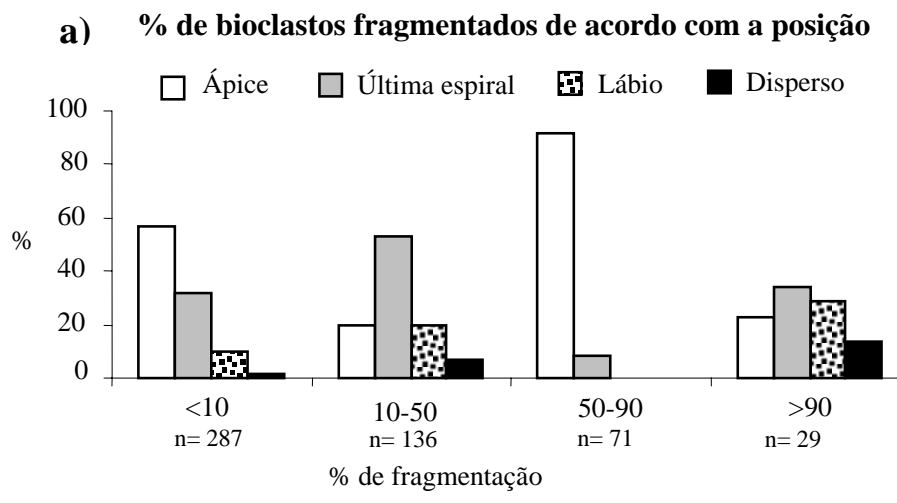

b) \% de fragmentação de acordo com o Taxon

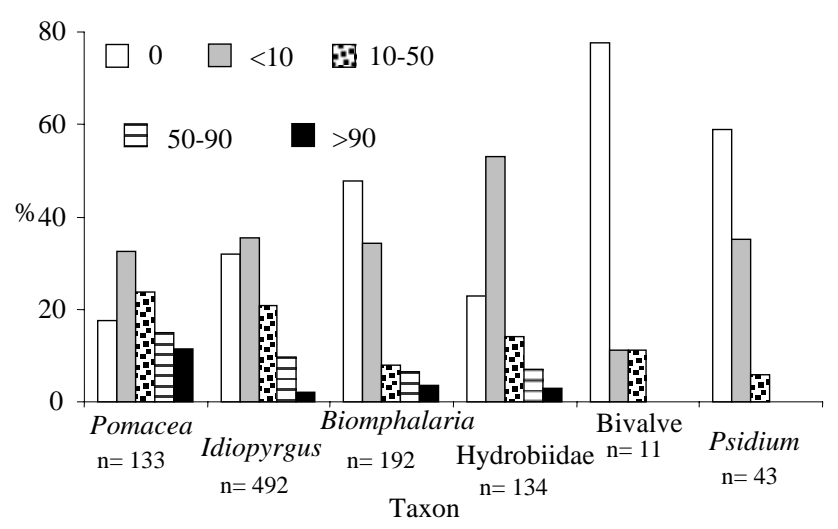

c) \% da posição de fragmentação de acordo com o Taxon

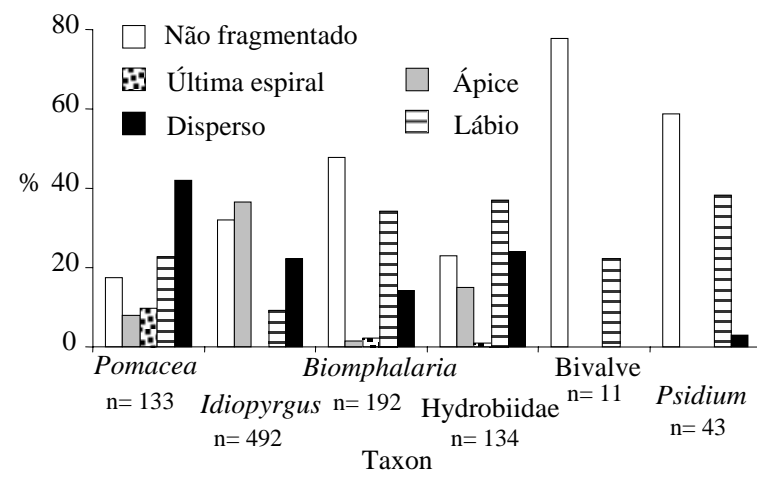

Figura 74 - Fragmentação dos bioclastos na análise em planta do bloco orientado. a) Porcentagem de bioclastos fragmentados de acordo com a posição. b) Porcentagem de fragmentação de acordo com o taxon. c) Porcentagem da posição de fragmentação de acordo com o taxon.

Considerando ainda a seleção por táxon, a friabilidade das conchas é mais significativa para Pomacea e os fragmentos encontrados (Figura 75 a). De modo idêntico à fragmentação, a friabilidade é influenciada pelo tempo de exposição do bioclasto, que neste caso também afeta os fragmentos.

Para textura alterada, a frequência é maior para os bivalves, Idiopyrgus e os indivíduos da Família Hydrobiidae (Figura 75), os últimos dois da mesma morfologia, mostrando-se menos resistentes que os demais bioclastos.

A porcentagem de conchas ainda com marcas da coloração é maior para Pomacea, Psidium e para os fragmentos. Os demais taxa apresentam 65\% ou mais de conchas esbranquiçadas (Figura 75 d). Estas marcas provavelmente se mantêm pela boa preservação do depósito. 

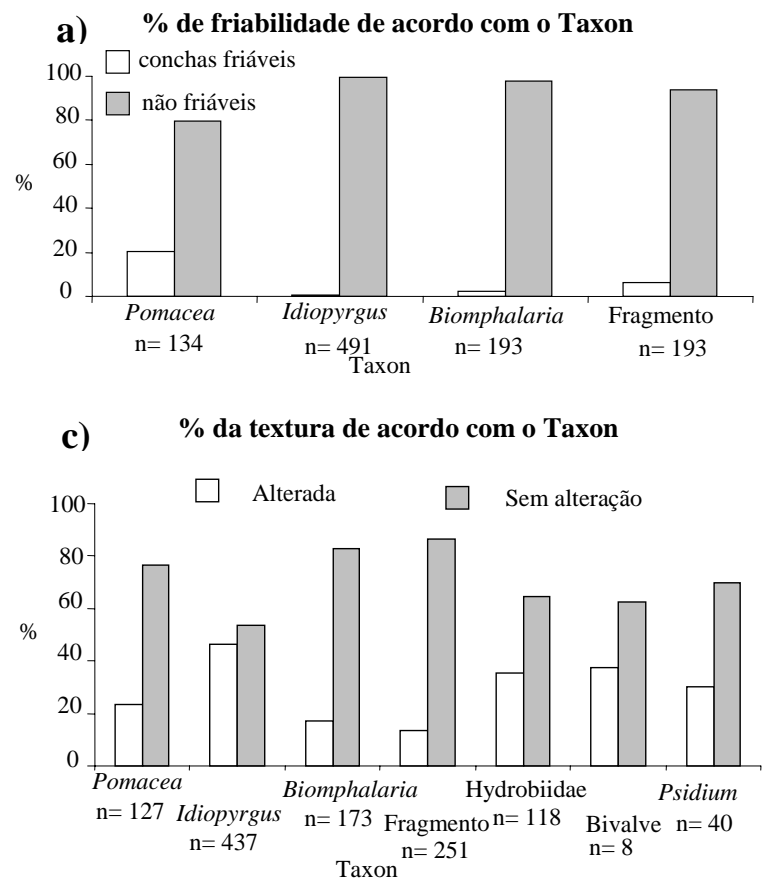

b) \% de condição dos bioclastos de acordo com o Taxon

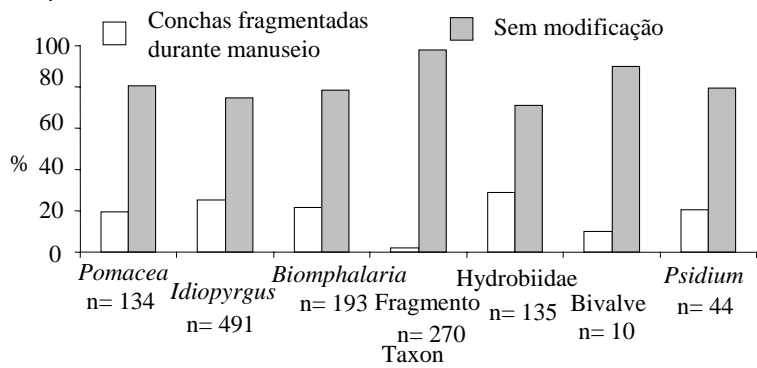

d) \% do tipo de coloração de acordo com o Taxon

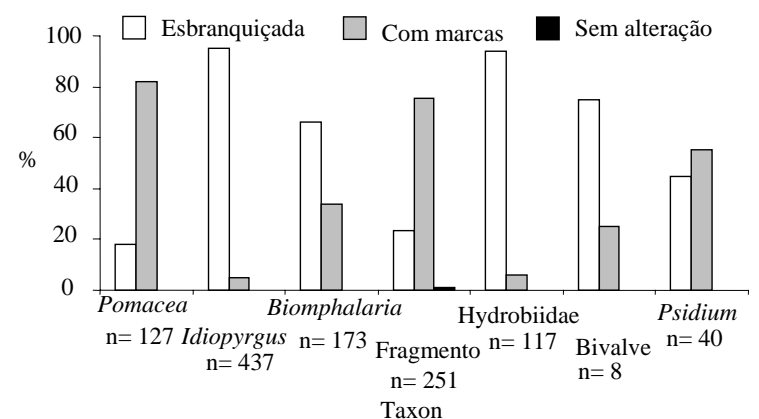

e) \% da orientação do bioclasto de acordo com o Taxon

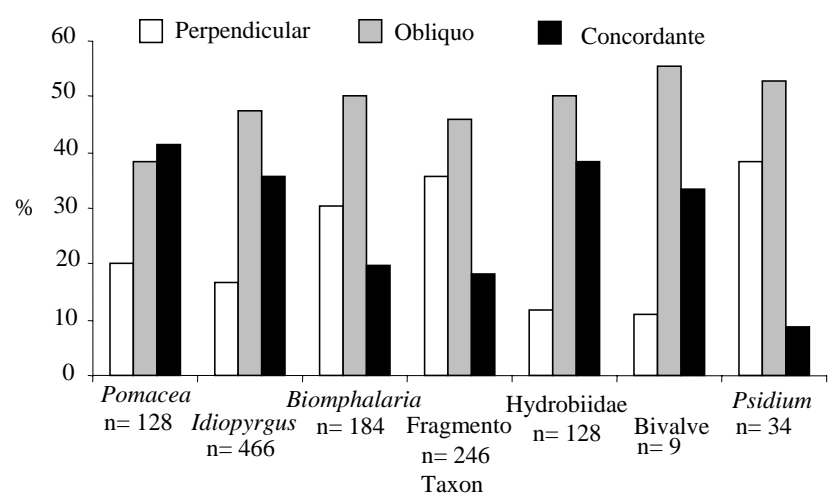

Figura 75 - Observações de acordo com o taxon dos bioclastos obtidos do bloco orientado da análise em planta. a) Porcentagem de friabilidade de acordo com o taxon. b) Porcentagem de condição dos bioclastos de acordo com o taxon. c) Porcentagem da textura de acordo com o taxon. d) Porcentagem do tipo de coloração de acordo com o taxon. e) Porcentagem da orientação dos bioclastos de acordo com o taxon.

É possível, como visto em campo, que a perda da coloração ocorra antes do processo de soterramento, relacionada à resistência da concha. Deste modo, Pomacea apesar de ter dimensões maiores, e por isso ser soterrada após Idiopyrgus, aparece com muitas marcas da coloração original, pois sua concha é mais resistente, por ser mais espessa. Da mesma forma, Psidium e os fragmentos são mais espessos que os demais taxa encontrados.

Em geral a maior porcentagem de orientação dos bioclastos é oblíqua (Figura 71 b), mas Pomacea apresenta-se bem dividida entre conchas oblíquas e concordantes. No caso de Idiopyrgus, moluscos da Família Hydrobiidae e bivalves cerca de 35\% possui orientação concordante, e Psidium e fragmentos apresentam-se perpendicularmente ao plano, também com 35\% de ocorrência. 
Observando o tamanho dos bioclastos como um todo, considerando altura e largura, nota-se grande concentração de bioclastos na porção de 0 a 10x10mm, tanto de fragmento, quanto de indivíduos. Biomphalaria e Idiopyrgus concentram-se de 0 a 10x5mm. Os bioclastos de maiores dimensões são indivíduos de Pomacea e fragmentos, provavelmente também de Pomacea (Figura 76).

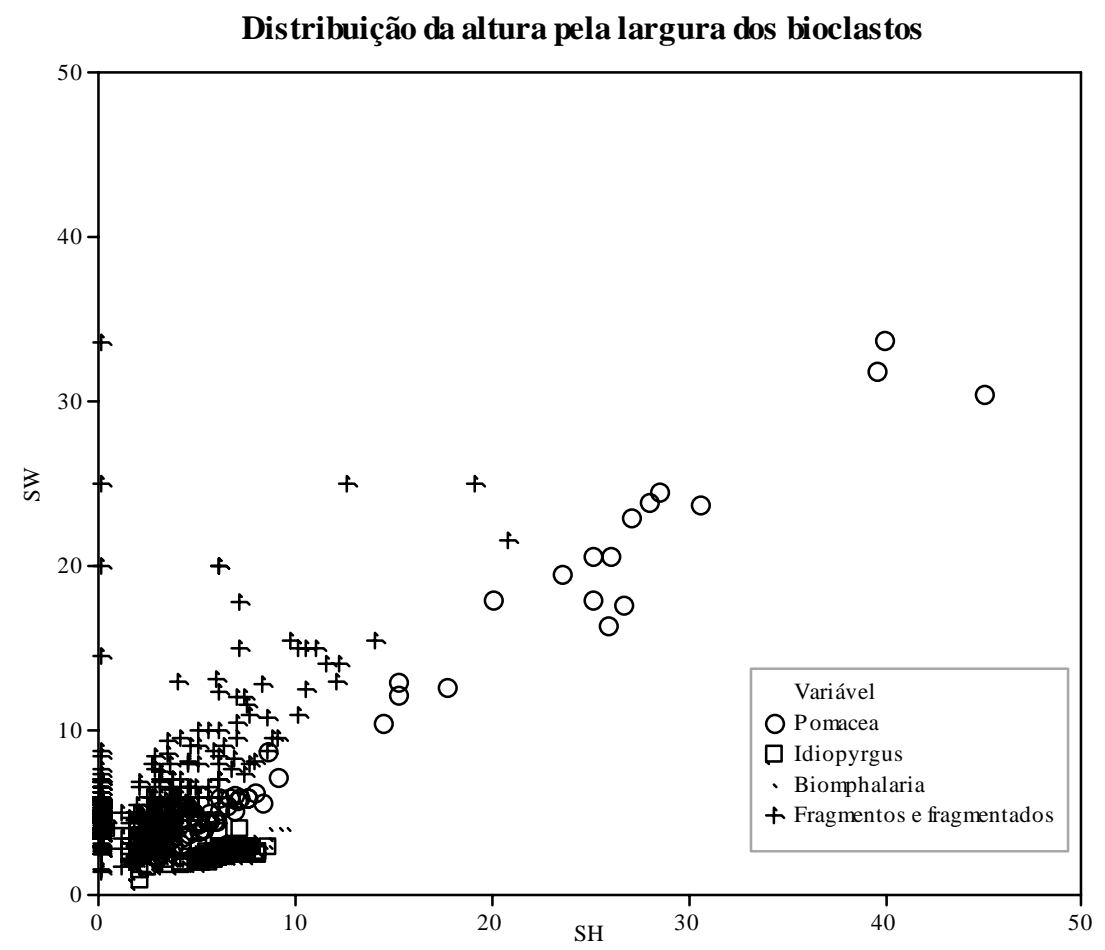

Figura 76 - Distribuição da altura (SH) pela largura (SW) dos bioclastos obtidos do bloco orientado estudado em planta.

\subsubsection{Análise do bloco orientado em perfil}

Foram analisados em perfil 4 horizontes, cada um com cerca de $5 \mathrm{~cm}$ de altura e $1 \mathrm{~cm}$ de espessura (Figura 11 d, pág. 40, e 77). Em 760g de sedimento retirado, havia 481 eram bioclastos. Em 100g de sedimento, ocorreram 63 bioclastos (Tabela 16).

Tabela 16 - Características do bloco orientado estudado em perfil.

\begin{tabular}{lr}
\hline \multicolumn{2}{c}{ Características do bloco estudado em perfil } \\
\hline Dimensões médias & $16,33 \times 30,50 \mathrm{~cm} \mathrm{AxL}$ \\
Peso do sedimento retirado & $760 \mathrm{~g}$ \\
$\mathrm{~N}^{\circ}$ total de bioclastos & 481 \\
$\mathrm{~N}^{0}$ de bioclastos para cada 100g & 63 \\
$\mathrm{~N}^{\mathrm{o}}$ de horizontes analisados & 4 \\
Altura dos horizontes & $5 \mathrm{~cm}$ \\
\hline
\end{tabular}


Cerca de 20\% dos bioclastos foram fragmentados durante manuseio. Apenas 1,25\% dos bioclastos foram considerados friáveis. O empacotamento do bloco é fraco, com $60 \%$ dos bioclastos com esta classificação, apenas 30 e 10\% dos bioclastos tem empacotamento denso e disperso respectivamente (Figura 78 a).

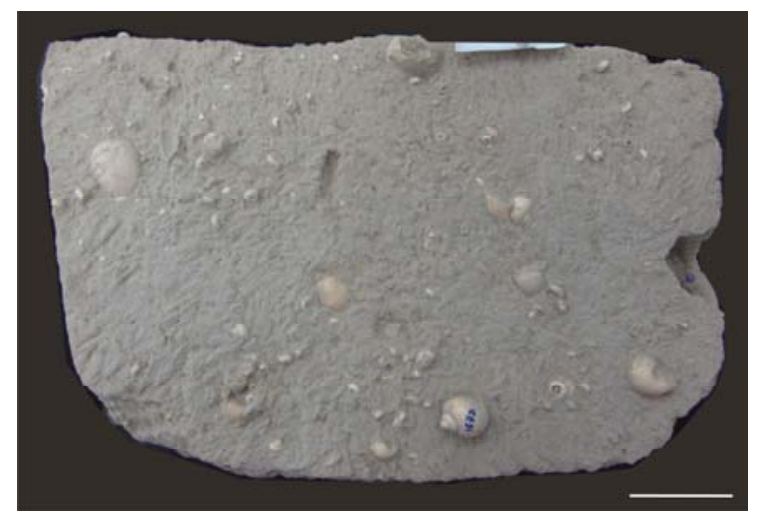
$5 \mathrm{~cm}$.

Figura 77 - Face norte do bloco orientado após a retirada dos horizontes para análise tafonômica. Escala

Há predomínio de bioclastos em posição oblíqua, cerca de 70\%, mesma porcentagem de bioclastos com textura não alterada. Cerca de 65\% apresentam a coloração ainda com algumas marcas, e 35\% esbranquiçada (Figura 78).

As alterações dos bioclastos são na maior parte corrosões, em poucos casos ocorrem incrustações. Estas alterações estão em 99\% das vezes dispersas nos bioclastos, sem preferência por região especifica (Figura 79).

Em 70\% dos bioclastos não ocorre fragmentação, os demais reduzem sua frequência de ocorrência com o aumento do intervalo de fragmentação (Figura 78 e). Dos cerca de 15\% de bioclastos que possuem menos de $10 \%$ de área fragmentada a maior parte possui fragmentação na porção dos lábios da concha, enquanto os demais intervalos são mais frequentes com fragmentação dispersa (Figura 80 a).

Quando observada a fragmentação de acordo com o taxon, Biomphalaria apresenta a menor taxa de não fragmentados, 85\%, seguido por Idiopyrgus, 60\%. A Família Hydrobiidae e o gênero Pomacea concentram-se com fragmentação menor que 10\% (Figura 80 b).

Pomacea e a Família Hydrobiidae têm as maiores freqüências de bioclastos fragmentados, concentradas nos lábios das conchas e dispersos. Dos indivíduos de Idiopyrgus fragmentados, a maior parte ocorre no ápice da concha (Figura 80 c). 
a) Empacotamento do depósito

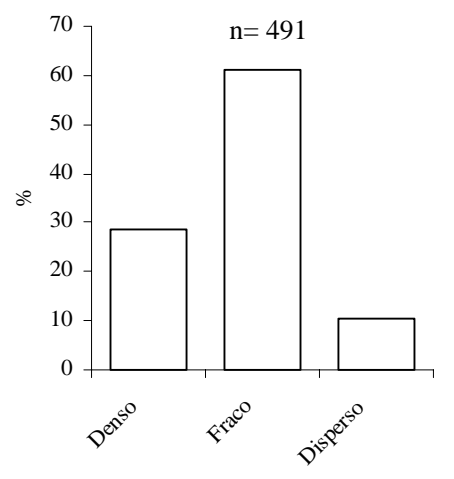

Empacotamento b) Orientação dos bioclastos

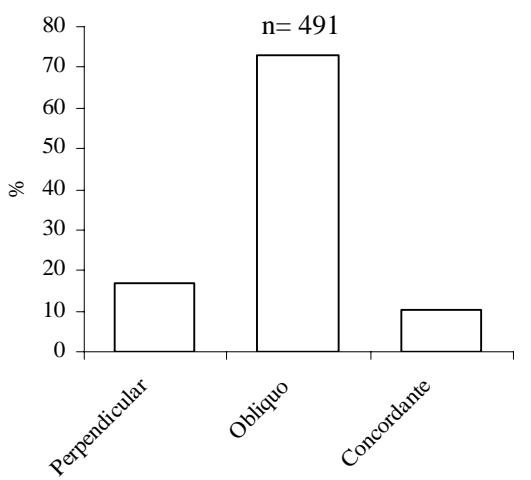

Orientação c) Textura dos bioclastos

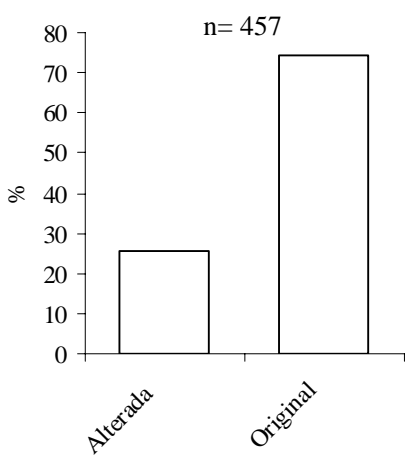

Textura d) Coloração dos bioclastos

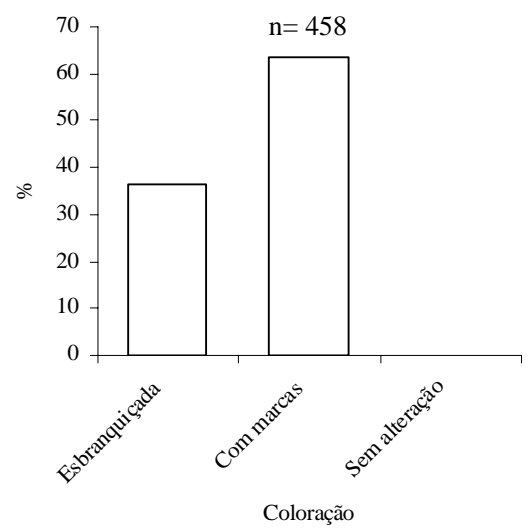

e) Fragmentação dos bioclastos

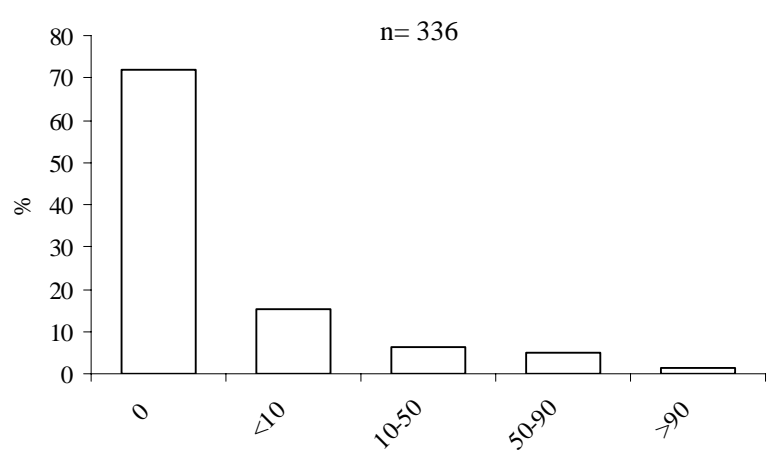

Intervalos de \% de fragmentação

Figura 78 - Análise do bloco em perfil. a) Empacotamento do depósito. b) Orientação dos bioclastos. c) Textura dos bioclasto. d) Coloração dos bioclastos. e) Fragmentação dos bioclastos.

a)

Alterações nos bioclastos

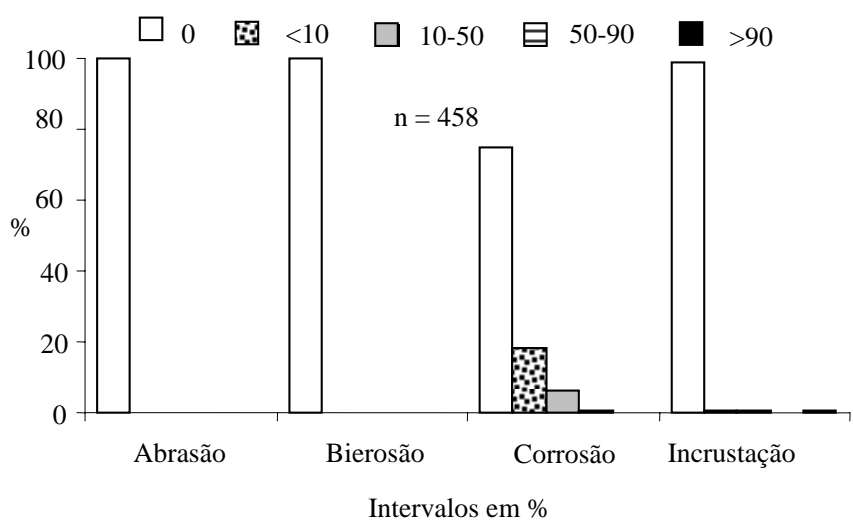

b) Posição da alteração nos bioclastos

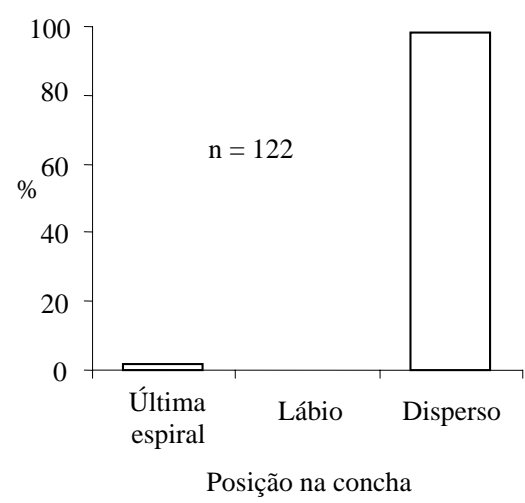

Figura 79 - Classificação de alteração dos bioclastos obtidos da análise do bloco orientado analisado em perfil. a) Alteração dos bioclastos. b) Posição da alteração nos bioclastos. 
a) \% de bioclastos fragmentados de acordo com a posição

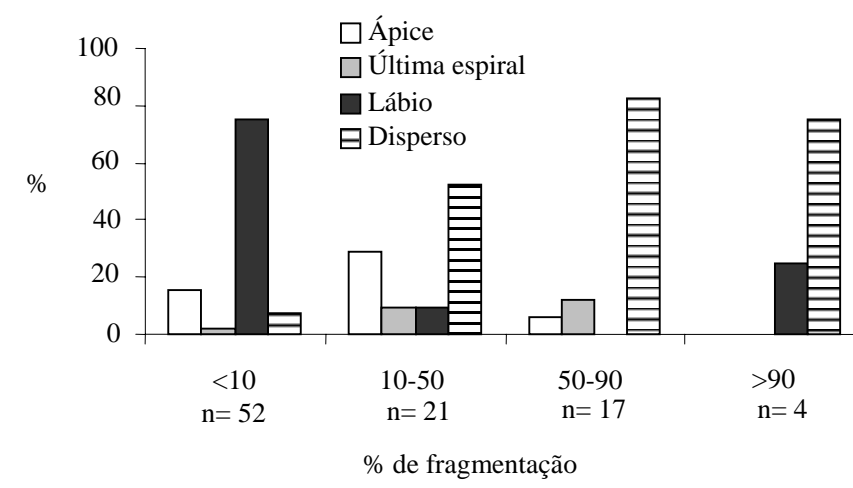

b) \% de fragmentação de acordo com o Taxon

c) \% da posição de fragmentação de acordo com o Taxon
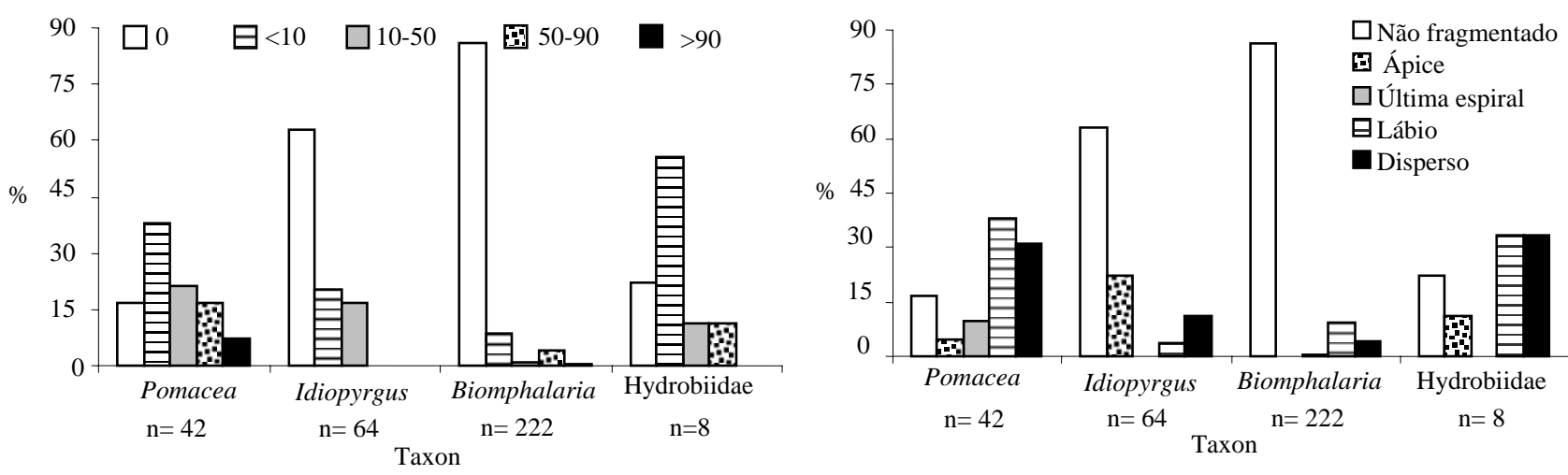

Figura 80 - Fragmentação dos bioclastos na análise em perfil do bloco orientado. a) Porcentagem de bioclastos fragmentados de acordo com a posição. b) Porcentagem de fragmentação de acordo com o Táxon. c) Porcentagem da posição de fragmentação de acordo com o Táxon.

\section{Distribuição da altura pela largura dos bioclastos}

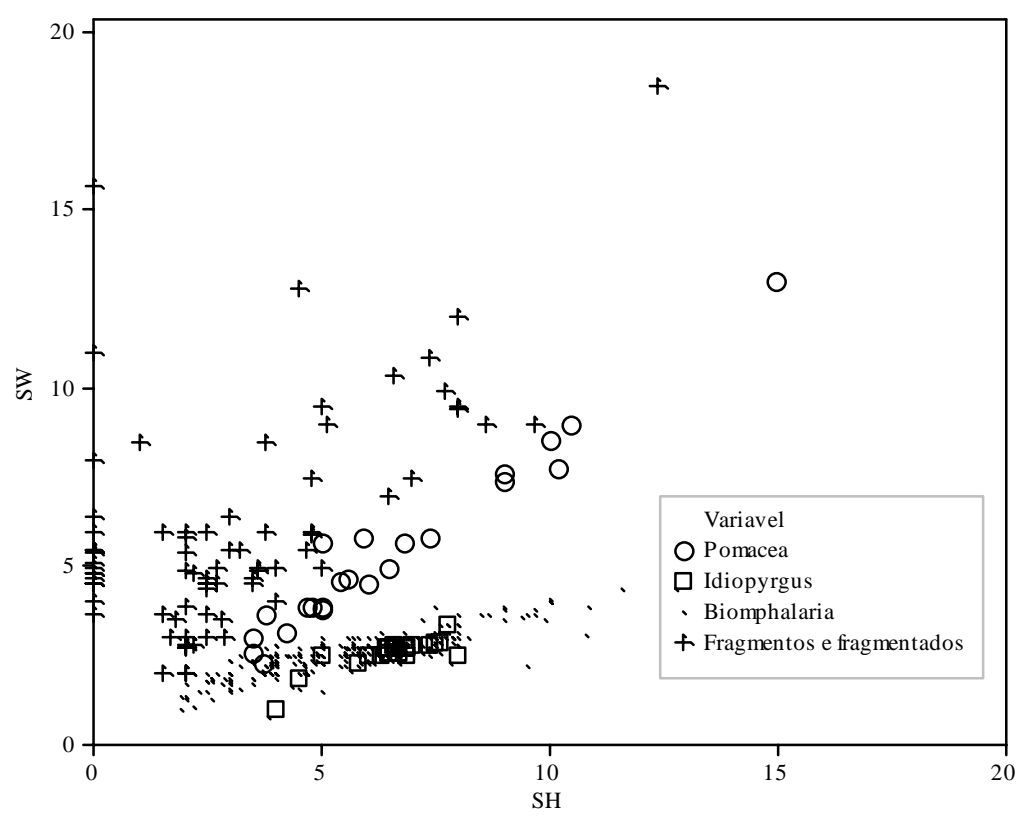

Figura 81 - Distribuição da altura (SH) pela largura (SW) dos bioclastos obtidos da análise em bloco orientado estudado em perfil. 
Uma pequena porcentagem de bioclastos friáveis pertencem ao gênero Pomacea e fragmentos (Figura 82 a). Em relação a porcentagem da condição dos bioclastos, Idiopyrgus foi o taxon mais fragmentado durante manuseio (Figura 82 b), refletindo maior fragilidade.

A textura das conchas é alterada em maior proporção para Idiopyrgus e para a Família Hydrobiidae (Figura 82 c). Os demais apresentam proporções semelhantes, entre 15 e 20\%.

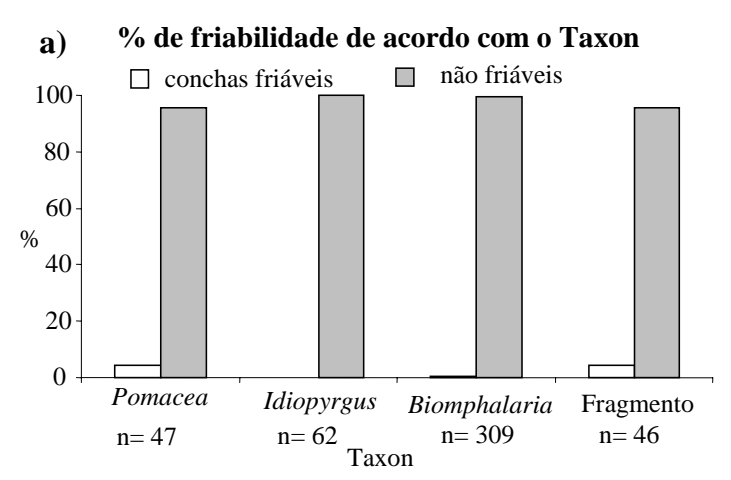

b) \% de condição dos bioclastos de acordo com o Taxon
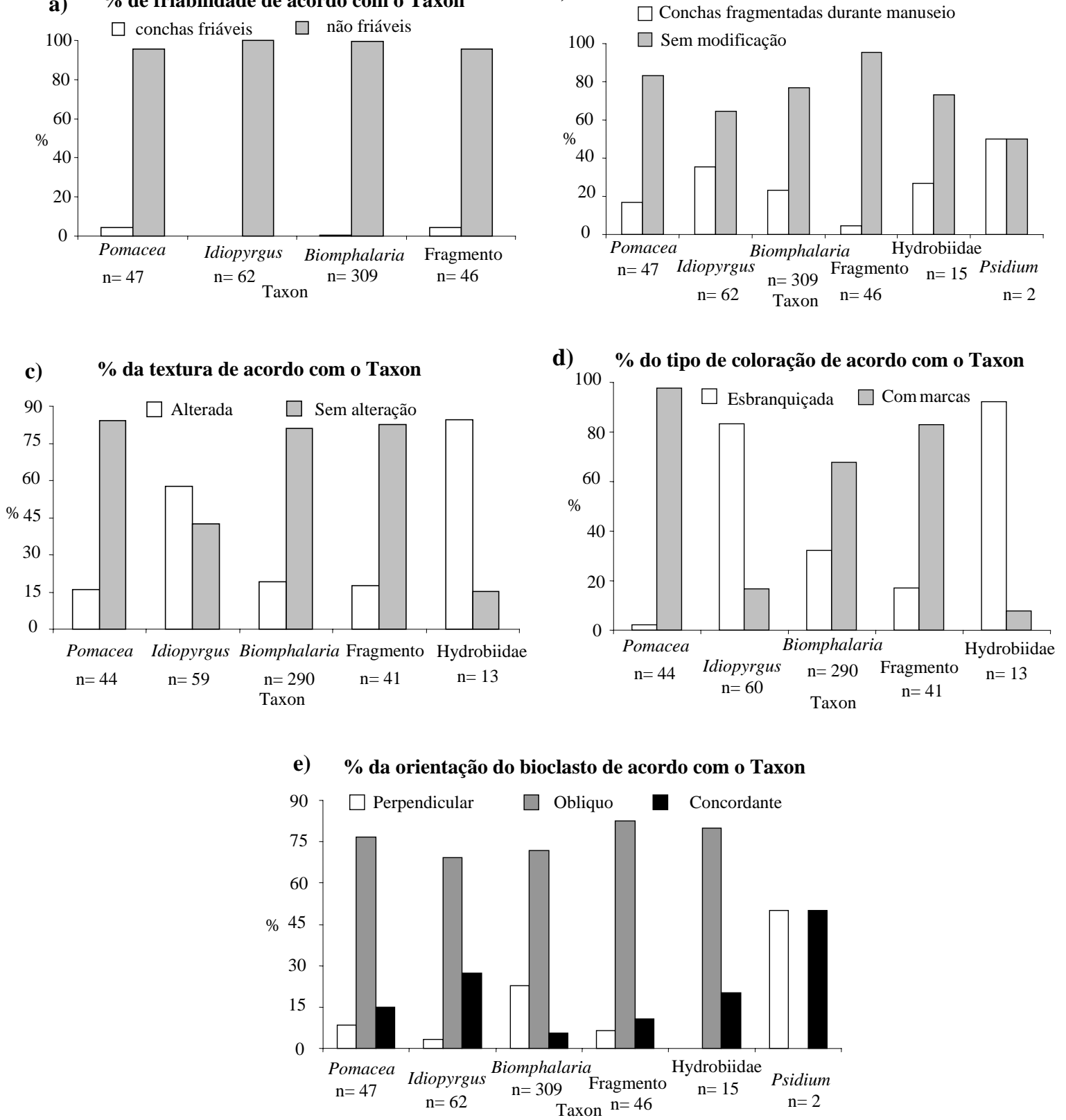

Figura 82 - Observações de acordo com o taxon dos bioclastos estudados em perfil no bloco orientado. a) Porcentagem de friabilidade de acordo com o taxon. b) Porcentagem de condição dos bioclastos de acordo com o taxon. c) Porcentagem da textura de acordo com o taxon. d) Porcentagem do tipo de coloração de acordo com o taxon. e) Porcentagem da orientação dos bioclastos de acordo com o taxon. 
Entre os 35\% de bioclastos esbranquiçados, os mais afetados são Idiopyrgus e a Família Hydrobiidae, já que são muito semelhantes (Figura 82 d). Entre os bioclastos que não são oblíquos quanto a orientação, a maior proporção de indivíduos perpendiculares ocorre com Biomphalaria, enquanto os demais apresentam orientação concordante e maior proporção depois de oblíquo.

Observando o tamanho dos bioclastos como um todo, eles se comportam da mesma forma que na análise em planta, concentram-se na porção de 0 a 10x10mm, tanto de fragmento, quanto de indivíduos. Ocorrem poucos bioclastos de maiores dimensões, indivíduos de Pomacea e fragmentos, pois provavelmente foram menos amostrados que na análise em planta (Figura 81).

\subsection{3 - Considerações}

Durante as análises pode-se observar a presença de alguns fragmentos de raízes, que mostram a presença de vegetação no depósito, possivelmente originadas da vegetação que cresce sobre o depósito atualmente. Algumas pequenas cavidades também são observadas, possivelmente resultado da degradação de matéria orgânica recoberta inicialmente por carbonato.

Comparando os dados obtidos da análise em planta e em perfil, o perfil apresenta maior concentração de bioclastos para cada 100g, cerca de 60, enquanto em planta apenas 34 . Os bioclastos em perfil apresentam menor proporção de indivíduos friáveis.

O empacotamento da análise em planta mostra equilíbrio entre disperso e fraco, enquanto em perfil o empacotamento é claramente fraco, com $70 \%$ de frequência. Na análise em perfil há maior frequência de bioclastos não fragmentados, principalmente para o gênero Biomphalaria, e de bioclastos com marcas, cerca de $60 \%$, contra $30 \%$ na análise em planta.

Considerando o depósito homogêneo, segundo a proporção de indivíduos de cada taxon entre as camadas, e entre os horizontes analisados em cada análise, o perfil do bloco analisado apresenta melhores condições de preservação que o topo do depósito, apesar de ambas apresentarem ótima preservação segundo as análises tafonômicas.

No entanto, estes dados podem ser reflexos do número de indivíduos amostrados, diferentes em cada análise, assim como a proporção de indivíduos por horizonte, quando 
comparado com a proporção encontrada em cada camada, considerando a espessura delas, já que a altura de cada horizonte amostrado teve, aproximadamente, a espessura de toda a camada analisada em planta.

As observações das Figuras 76 e 81, traçadas através do estudo do bloco da Mineração Calcário Xaraés orientado em perfil e em planta, demonstraram a ausência de relação hidráulica, por taxa, dos tamanhos dos indivíduos. As maiores frequências de tamanho se situam entre $5 \mathrm{~mm}$ de altura e $10 \mathrm{~mm}$ de largura (curva de crescimento).

Não foi possível a análise, em perfil, de cada horizonte referente a cada camada, pois o número de amostragem de indivíduos não seria suficiente para as análises estatísticas. Amostras de maiores dimensões seriam necessárias, além de mais tempo disponível para análise. Da mesma forma, a análise de todo o bloco em planta exigiria mais tempo disponível.

Apesar da concentração dos bioclastos de 0 a 10x10mm, eles não refletem seleção, e sim limites do tamanho natural dos taxa encontrados, a presença de Pomacea prova que não ocorre seleção, pois apresenta tamanho superior aos demais.

As divergências de gráficos derivados dos dois tipos de amostragem (perfil e planta), não são significativas. Os gráficos refletem falta de transporte ponderável na interface águasedimento, com baixo impacto dos bioclastos quanto a fragmentação e alteração. As alterações verificadas provavelmente devem-se ao tempo de exposição na interface águasedimento. A ausência de estruturas sedimentares nos depósitos estudados reforçam estes pontos de vista.

\subsection{Análises morfológicas dos gastrópodes}

\subsubsection{Gastrópodes do bloco analisado em planta}

A partir dos dados de biometria, foi calculada a média das medidas obtidas (Tabela 17 e Figura 83). Os indivíduos de Pomacea apresentaram os maiores desvios padrões entre os gastrópodes analisados, com indivíduos variando de 2,0x1, 9 mm a 45x33, 7 mm (altura x largura) com 1 a 6 voltas, com média 3. Com o aumento do número de voltas cai sua frequência (Figura 84). 
Segundo Estebenet (1998), que estudou o crescimento de conchas de Pomacea canaliculata, as razões largura da concha - altura da concha (SW/SH), largura da abertura altura da concha (AW/SH) e altura das primeiras espirais - altura da concha $(\mathrm{Sph} / \mathrm{SH})$ aumentam em relação ao crescimento das conchas.

Assim considerando tais razões (Tabela 18) para Pomacea tem-se conchas de razões médias $0,83,0,55$ e 0,13 respectivamente $\mathrm{SW} / \mathrm{SH}, \mathrm{AW} / \mathrm{SH}$ e $\mathrm{Sph} / \mathrm{SH}$ (Figura 85). SW/SH apresenta uma distribuição com moda entre 0,8 e 0,9 , já AW/SH é muito semelhante a distribuição normal, com desvio padrão próximo a zero. Para $\mathrm{Sph} / \mathrm{SH}$ a razão é de $0,1 \mathrm{em}$ cerca de $70 \%$ dos casos.

Observando a Figura 86 pode-se notar, conforme afirma Estebenet (1998), que as proporções de altura da concha, e largura da abertura e largura da concha aumentam com o crescimento vertical da concha (altura).

Assim, tem-se número maior de indivíduos jovens, de menor altura e largura, entre 10x10mm, e número reduzido de indivíduos mais velhos, marcando uma população com taxas normais de nascimento e morte, caracterizando um depósito não catastrófico.

Os fragmentos apresentam média de 2,46 $\mathrm{mm}^{2}$, com mínimo de 1,7 e máximo de $217 \mathrm{~mm}^{2}$ (Tabela 17).

O gênero Idiopyrgus apresenta indivíduos de 1,5x1,0 mm a 8,5x4,2mm (alturaxlargura), com médias de 5,96mm e 2,62 $\mathrm{mm}$ para altura e largura da concha respectivamente (Tabela 17e Figura 84). O número de voltas das conchas varia de 3 a 7, com média 6 (Figura 83).

As razões obtidas apresentam baixo desvio padrão (Tabela 18) e modas bem marcadas. Na Figura 87 a moda é de $70 \%$ entre 0,4 e 0,5 para SW/SH e em $80 \%$ em 0,3 para AW/SH.

As relações morfológicas de Idiopyrgus não obedecem a uma relação linear clara (Figura 86), a variação de altura é maior do que a variação de largura da concha, e vários pontos não obedecem a regressão linear. Isto sugere que as variáveis largura e altura não crescem nas mesmas proporções. 
Tabela 17 - Análise estatística da biometria das conchas obtidas da análise do bloco orientado em planta.

\begin{tabular}{|c|c|c|c|c|c|c|}
\hline \multicolumn{7}{|c|}{ Resultados estatísticos da análise da biometria das conchas } \\
\hline \multicolumn{7}{|c|}{ Pomacea } \\
\hline Variáveis (mm) & Média & Desvio padrão & Mínimo & Máximo & $\mathrm{N}$ & $\mathrm{N}$ válido \\
\hline Sph & 1,84 & 2,38 & 0 & 13,50 & 135 & 58 \\
\hline $\mathrm{SH}$ & 10,64 & 10,14 & 2,00 & 45,00 & 135 & 72 \\
\hline $\mathrm{AH}$ & 7,56 & 6,67 & 0,80 & 27,50 & 135 & 58 \\
\hline SW & 8,80 & 7,95 & 1,90 & 33,70 & 135 & 83 \\
\hline AW & 6,32 & 5,48 & 1,20 & 20,50 & 135 & 60 \\
\hline Voltas & 2,98 & 1,13 & 1 & 6 & 135 & 55 \\
\hline \multicolumn{7}{|c|}{ Idiopyrgus } \\
\hline $\mathrm{SH}$ & 5,96 & 1,44 & 1,50 & 8,50 & 491 & 116 \\
\hline $\mathrm{AH}$ & 1,73 & 0,29 & 0,50 & 2,70 & 491 & 270 \\
\hline SW & 2,62 & 0,32 & 1,00 & 4,20 & 491 & 306 \\
\hline AW & 1,86 & 0,22 & 0,90 & 2,90 & 491 & 272 \\
\hline Voltas & 5,65 & 0,80 & 3 & 7 & 491 & 105 \\
\hline \multicolumn{7}{|c|}{ Biomphalaria } \\
\hline Sph & 1,67 & 1,00 & 0,50 & 7,50 & 193 & 97 \\
\hline $\mathrm{SH}$ & 4,96 & 1,82 & 1,50 & 9,50 & 193 & 143 \\
\hline SW & 2,53 & 0,56 & 1,00 & 4,10 & 193 & 127 \\
\hline \multicolumn{7}{|c|}{ Fragmento } \\
\hline Área $\left(\mathrm{mm}^{2}\right)$ & 2,46 & 31,67 & 1,70 & 217,00 & 270 & 234 \\
\hline \multicolumn{7}{|c|}{ Família Hydrobiidae } \\
\hline $\mathrm{SH}$ & 4,86 & 1,25 & 2,50 & 7,10 & 135 & 58 \\
\hline $\mathrm{AH}$ & 1,47 & 0,56 & 0,40 & 4,00 & 135 & 39 \\
\hline SW & 2,33 & 0,44 & 1,50 & 3,80 & 135 & 80 \\
\hline AW & 1,65 & 0,42 & 1,00 & 3,30 & 135 & 36 \\
\hline Voltas & 5,40 & 0,86 & 4 & 7 & 135 & 62 \\
\hline
\end{tabular}

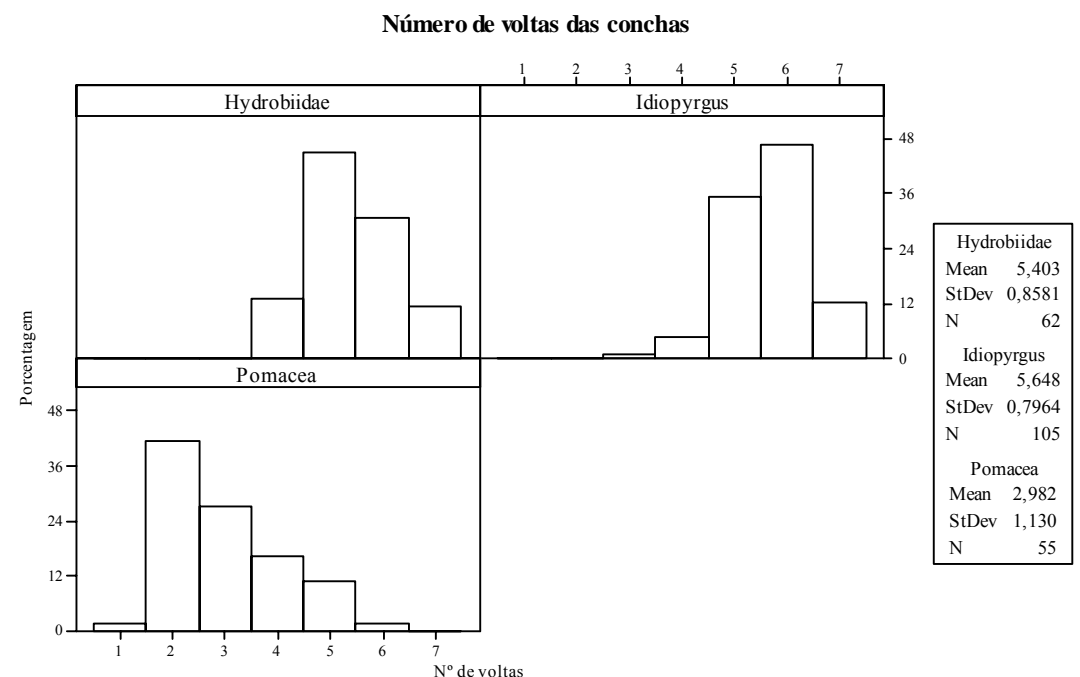

Figura 83 - Número de voltas das conchas para Idiopyrgus, Hydrobiidae e Pomacea obtidos da amostra orientada em planta. 


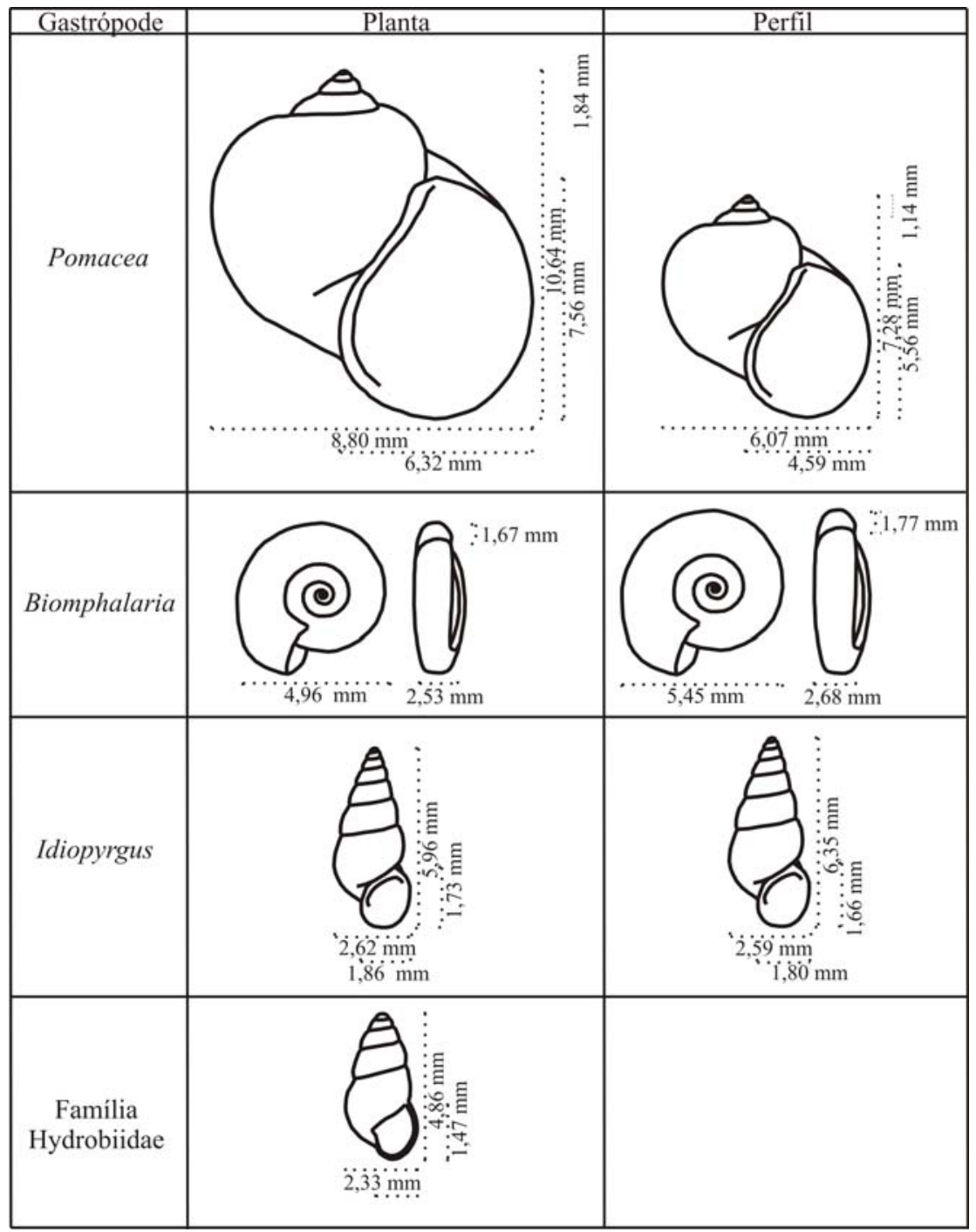

Figura 84 - Médias obtidas dos gastrópodes analisados no bloco orientado em planta e perfil. A proporção entre os gastrópodes foi mantida.

Tabela 18 - Razões para as variáveis biométricas analisadas obtidas das conchas da análise do bloco em planta. Tais razões aumentam em relação com crescimento da concha (Estebenet, 1998).

\begin{tabular}{ccccccc}
\hline \multicolumn{7}{c}{ Razões para as variáveis de biometria } \\
\hline \multicolumn{7}{c}{ Pomacea } \\
Variáveis (m) & Média & Desvio padrão & Mínimo & Máximo & $\mathrm{N}$ & N válido \\
SW/SH & 0,83 & 0,11 & 0,45 & 1,08 & 135 & 61 \\
AW/SH & 0,55 & 0,08 & 0,24 & 0,73 & 135 & 47 \\
Sph/SH & 0,13 & 0,16 & 0,02 & 1,03 & 135 & 48 \\
& 0,45 & Idiopyrgus \\
SW/SH & 0,30 & 0,15 & 0,33 & 1,80 & 491 & 106 \\
AW/SH & 0,10 & 0,20 & 1,13 & 491 & 94 \\
& 0,54 & Biomphalaria & & & \\
SW/SH & 0,34 & 0,21 & 0,34 & 2,50 & 193 & 126 \\
Sph/SH & 0,40 & 0,13 & 3,00 & 193 & 96 \\
& 0,48 & Hydrobiidae & & & \\
SW/SH & 0,12 & 0,36 & 1,27 & 135 & 56 \\
AW/SH & 0,28 & 0,13 & 0,11 & 0,80 & 135 & 24 \\
\hline \multicolumn{7}{c}{}
\end{tabular}




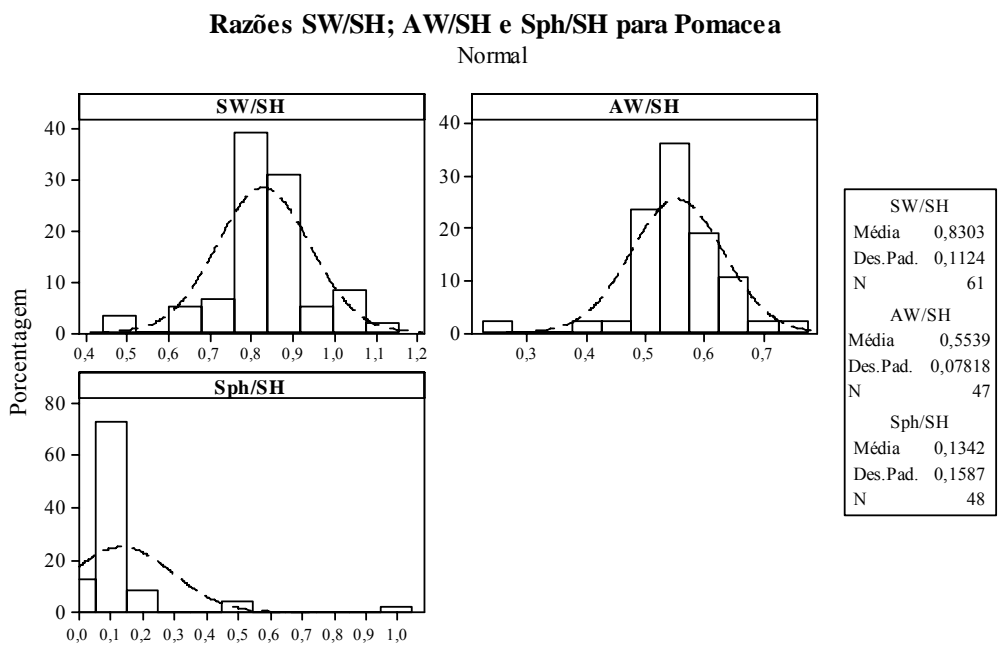

Figura 85 - Gráficos para as razões biométricas analisadas dos indivíduos do gênero Pomacea obtidos na análise do bloco em planta.

Indivíduos de Biomphalaria apresentam largura média de 4,96mm, com altura da concha $2,53 \mathrm{~mm}$ e altura da abertura de $1,67 \mathrm{~mm}$ (Tabela 17 e Figura 84). A maior concha encontrada apresenta 9,5x4, 1x7,5 (SHxSWxSph) e a menor 1,5x1,0x0,50. Os desvios padrões deste gênero ficam abaixo de 2 pontos.

As razões largura da concha pela altura da concha $(\mathrm{SW} / \mathrm{SH})$, e largura da abertura da concha pela altura da concha $(\mathrm{Sph} / \mathrm{SH})$ apresentam moda definida, como para Idiopyrgus, neste caso de 0,4 e 0,6, e entre 0,1 e 0,4 respectivamente (Figura 88).

Assim como para Idiopyrgus, Biomphalaria não apresenta desenvolvimento linear bem definido para a relação altura e largura da concha. A Figura 86 mostra a distribuição da relação e a regressão linear, diversos pontos não acompanham a reta. Da mesma forma comportam-se os indivíduos da Família Hydrobiidae.

A Família Hydrobiidae apresenta médias de 4,86x2,33 mm (alturaxlargura da concha), as maiores medidas são $7,1 \times 4 \mathrm{~mm}$ e as menores $2,5 \times 1,5 \mathrm{~mm}$ (Tabela 17 e Figura 84 ). Apresenta conchas com 4 a 7 voltas, com média 5 (Figura 83).

Para este taxon a razão largura da concha e da abertura pela altura, com média de 0,48 e 0,28 , respectivamente, também com desvio padrão próximo a zero (Tabela 18). Observando a Figura 89 nota-se que ocorre uma moda entre 0,4 e 0,5 , somando cerca de $80 \%$. A razão calculada para este taxon é muito próxima a de Idiopyrgus, sugerindo desenvolvimento semelhante. 

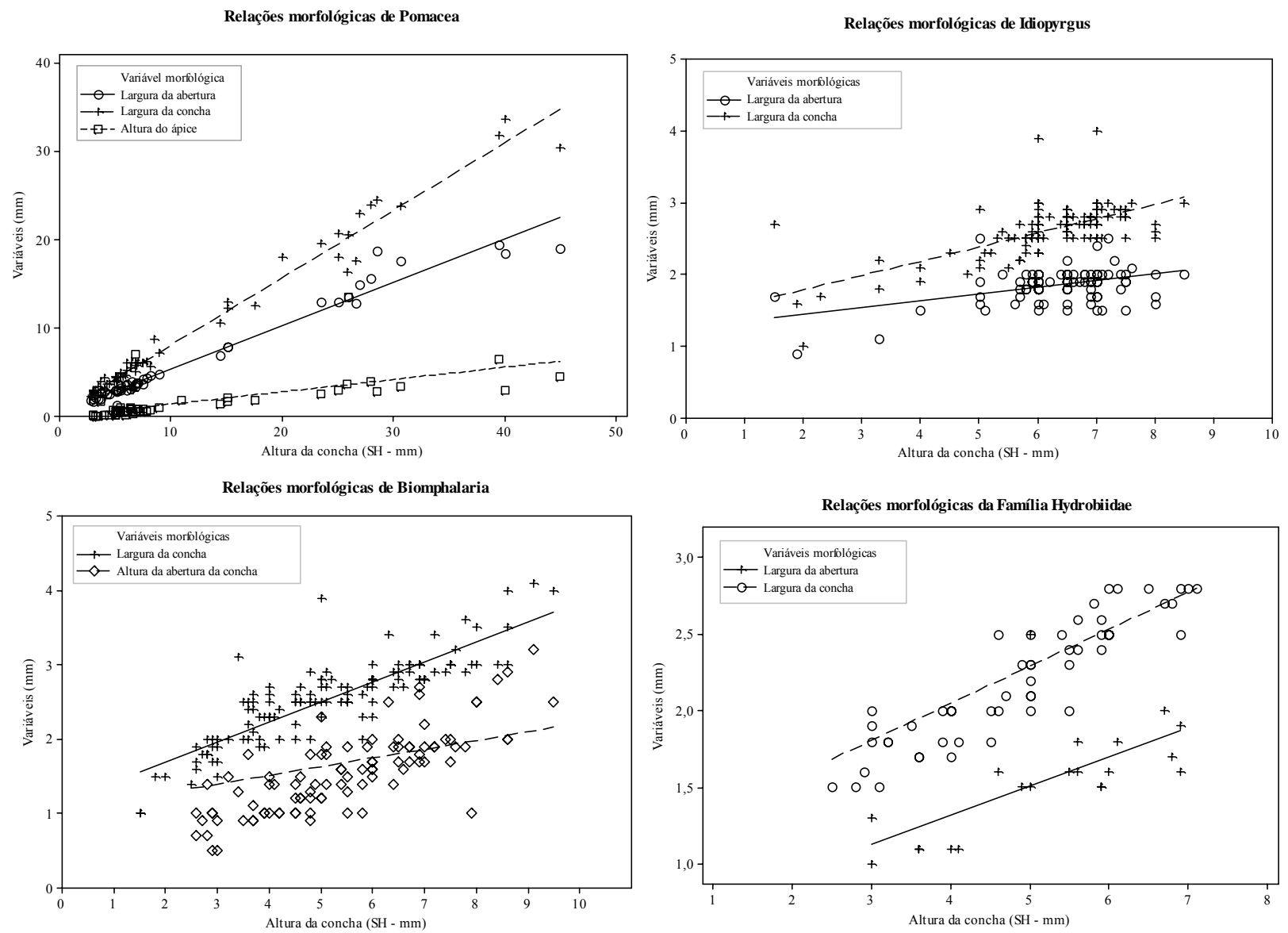

Figura 86 - Relações morfológicas de Pomacea, Idiopyrgus, Biomphalaria e para a Família Hydrobiidae obtidos na análise do bloco orientado em planta.

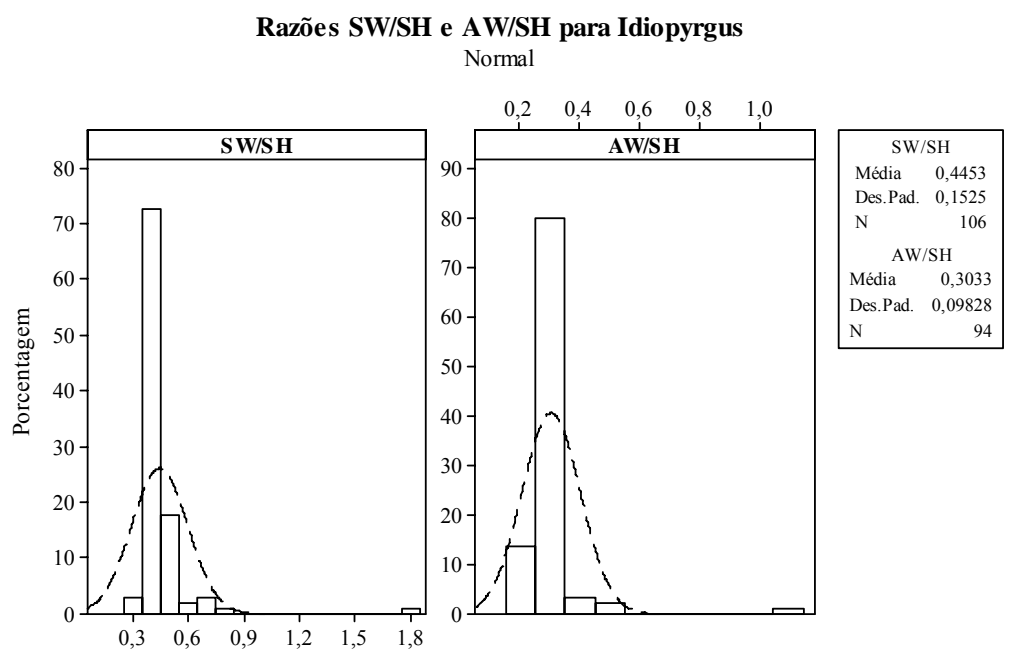

Figura 87 - Razões de largura da concha (SW) pela altura da concha (SH) e largura da abertura (AW) pela altura da concha para indivíduos do gênero Idiopyrgus obtidos na análise do bloco orientado em planta. 


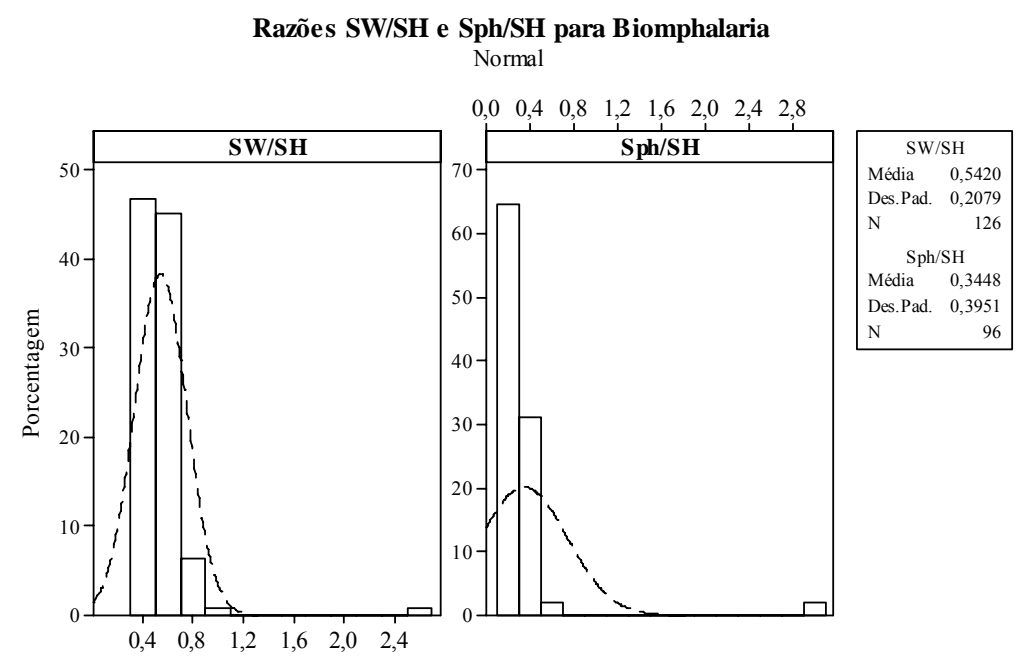

Figura 88 - Razões de largura da concha (SW) pela altura da concha (SH) e largura da abertura (Sph) pela altura da concha para indivíduos do gênero Biomphalaria obtidos na análise do bloco orientado em planta.

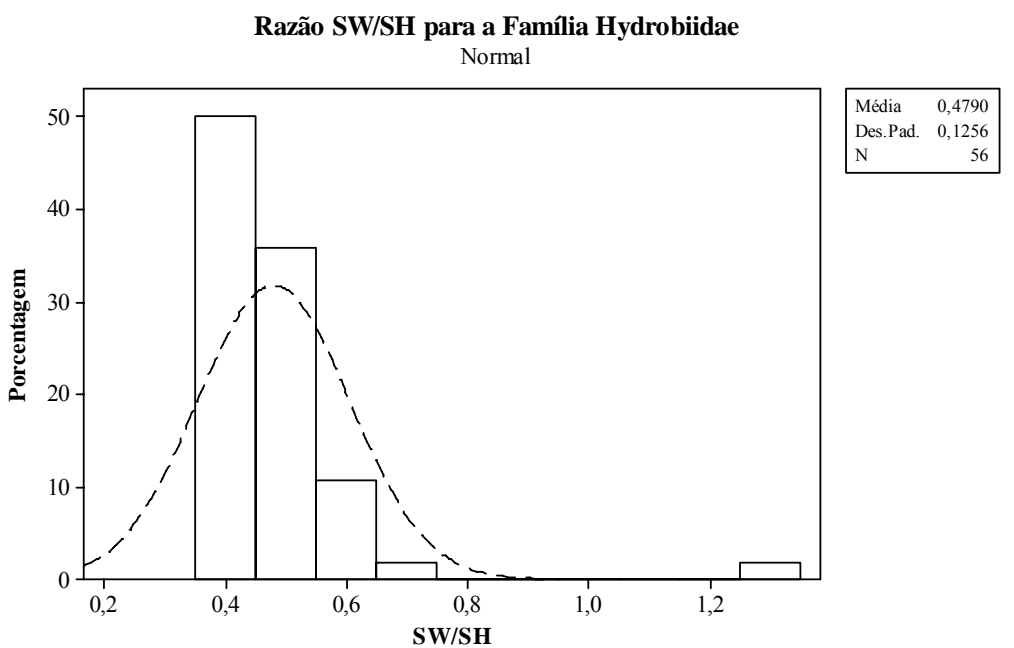

Figura 89 - Razão largura da concha (SW) pela altura da concha (SH) para indivíduos da Família Hydrobiidae obtidos na análise do bloco orientado em planta. 

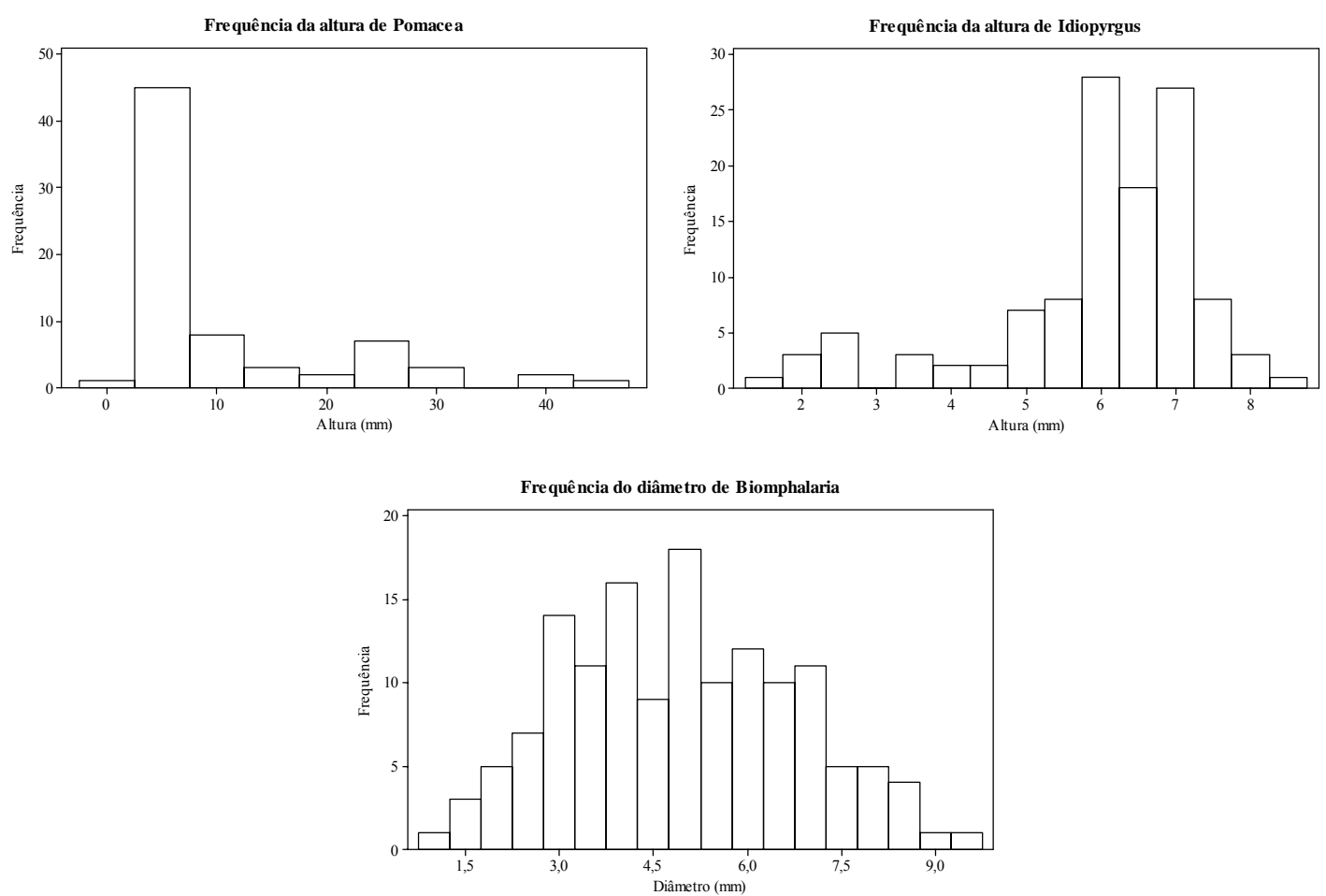

Figura 90 - Frequências da altura dos gêneros Pomacea e Idiopyrgus, e diâmetro de Biomphalaria quando analisados em planta na amostra.

Observando-se somente a frequência de altura para Pomacea (Figura 90), nota-se tamanhos preferenciais em torno de $5 \mathrm{~mm}$ de altura, no entanto, para melhor avaliação deste taxon, a amostragem deveria ser maior, por conta das dimensões do gênero.

Idiopyrgus apresenta uma distribuição mais uniforme, há maior frequência de indivíduos entre 6 e $7 \mathrm{~mm}$ de altura, com menor quantidade de indivíduos menores, entretanto, conchas muito pequenas podem ter sido eliminadas do depósito por ações intempéricas pós-deposicionais, por tratar-se de um depósito permeável.

No caso do gênero Biomphalaria a curva de frequência apresenta uma distribuição próxima a normal, semelhante à encontrada para indivíduos atuais do mesmo gênero segundo trabalhos de Utzinger et al. (1997) e Utzinger \& Tanner (2000).

\subsubsection{Gastrópodes do bloco analisado em perfil}

A análise morfológica dos bioclastos registra fragmentos de 29,93 $\mathrm{mm}^{2}$, com mínimo de 1,1 e máximo de 229,4mm², com desvio padrão alto, cerca de 40 (Tabela 19). Os indivíduos de Pomacea apresentam médias 7,28x6,07 $\mathrm{mm}$ para altura pela largura e altura e 
largura da abertura com média 5,56 e 4,59 $\mathrm{mm}$ respectivamente, e altura do ápice média de 1,14 mm, média de 3 voltas, variando de 2 a 4 (Tabela 19, Figura 91 e Figura 84).

As conchas de Pomacea variam de 3x2,3 mm até 24,4x16 mm de altura e largura (Tabela 19), no entanto, apresentam menores desvios padrões que a análise em planta.

Considerando a razões obtidas por Estebenet (1998) tem-se razões médias de 0,83, 0,57 e 0,12 para SW/SH, AW/SH e Sph/SH (Tabela 20). A razão SW/SH não apresenta continuidade em sua representação gráfica (Figura 92), com moda entre 0,80 e 0,84. AW/SH é mais uniforme próxima a uma distribuição normal, no entanto, $\mathrm{Sph} / \mathrm{SH}$ é maior que $5 \%$ a partir de 0,1 caindo até 0,25 para $5 \%$ novamente.

Apesar da uniformidade dos dados de SW/SH não serem contínuos, há evolução linear do crescimento de Pomacea, assim como para os indivíduos da análise em planta (Figura 93), as relações $\mathrm{SW} / \mathrm{SH}, \mathrm{AW} / \mathrm{SH}$ w $\mathrm{Sph} / \mathrm{SH}$ comportam-se da mesma maneira.

Tabela 19 - Análise estatística da biometria das conchas obtidas do bloco orientado estudado em perfil.

\begin{tabular}{|c|c|c|c|c|c|c|}
\hline \multicolumn{7}{|c|}{ Resultados estatísticos da análise da biometria das conchas } \\
\hline \multicolumn{7}{|c|}{ Pomacea } \\
\hline Variáveis & Média & Desvio padrão & Mínimo & Máximo & $\mathrm{N}$ & $\mathrm{N}$ válido \\
\hline Sph & 1,14 & 0,92 & 0,10 & 4,30 & 47 & 20 \\
\hline SH & 7,28 & 4,82 & 3,00 & 24,40 & 47 & 29 \\
\hline $\mathrm{AH}$ & 5,56 & 2,60 & 2,80 & 12,00 & 47 & 20 \\
\hline SW & 6,07 & 3,19 & 2,30 & 16,00 & 47 & 27 \\
\hline AW & 4,59 & 1,96 & 2,00 & 9,50 & 47 & 20 \\
\hline Voltas & 2,81 & 0,68 & 2 & 4 & 47 & 21 \\
\hline \multicolumn{7}{|c|}{ Idiopyrgus } \\
\hline $\mathrm{SH}$ & 6,35 & 1,25 & 2,60 & 8,00 & 62 & 24 \\
\hline $\mathrm{AH}$ & 1,66 & 0,29 & 0,90 & 2,20 & 62 & 44 \\
\hline SW & 2,59 & 0,32 & 1,00 & 3,40 & 62 & 51 \\
\hline AW & 1,80 & 0,19 & 1,00 & 2,00 & 62 & 45 \\
\hline Voltas & 6,22 & 1,00 & 4 & 8 & 62 & 23 \\
\hline \multicolumn{7}{|c|}{ Biomphalaria } \\
\hline Sph & 1,77 & 0,66 & 0,50 & 4,90 & 308 & 208 \\
\hline SH & 5,45 & 2,06 & 1,50 & 12,60 & 308 & 270 \\
\hline SW & 2,68 & 1,39 & 1,00 & 22,50 & 308 & 246 \\
\hline \multicolumn{7}{|c|}{ Fragmento } \\
\hline Área (mm) & 29,93 & 39,71 & 1,10 & 229,40 & 46 & 39 \\
\hline
\end{tabular}

O gênero Idiopyrgus apresenta indivíduos com média $6,35 \times 2,59 \mathrm{~mm}$ de altura pela largura, variando de conchas de 2,6x0,32 $\mathrm{mm}$ a $8 \times 3,4 \mathrm{~mm}$ de altura pela largura, a altura e a largura da abertura têm médias 1,66 e 1,8mm (Tabela 19). O número de voltas varia de 4 a 8 com média 6 (Tabela 19) com moda de cerca de 80\% entre 6 e 7 (Figura 91). 
As razões obtidas para as variáveis morfológicas de Idiopyrgus apresentaram desvio padrão muito baixo, com médias 0,40 e 0,28 para $\mathrm{SW} / \mathrm{SH}$ e $\mathrm{AW} / \mathrm{SH}$, com moda entre 0,40 e 0,43, e em 0,28 respectivamente (Figura 94). A relação de SW/SH e AW/SH é semelhante a encontrada para a análise em planta (Figura 86), não há relação linear clara e muitos pontos não seguem a reta de distribuição.

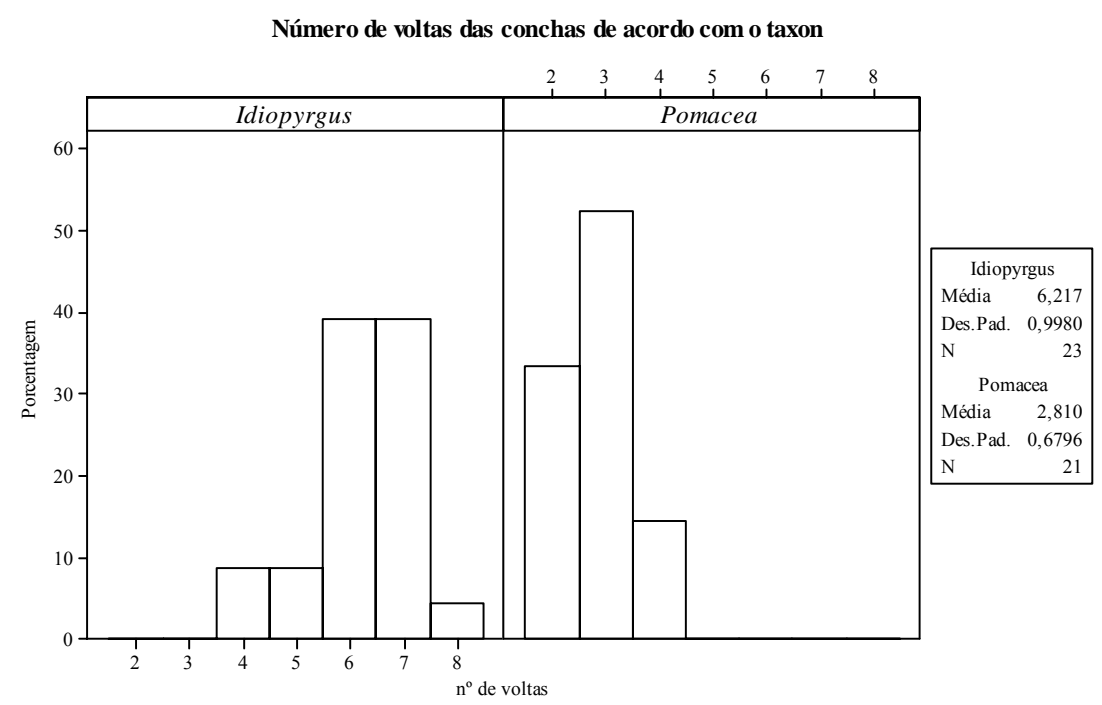

Figura 91 - Número de voltas das conchas para Idiopyrgus e Pomacea obtidos no bloco orientado estudado em perfil.

Tabela 20 - Razões para as variáveis biométricas dos gastrópodes obtidos no bloco orientado analisado em perfil.

\begin{tabular}{crrrrrr}
\hline \multicolumn{7}{c}{ Razões para as variáveis de biometria } \\
\hline \multicolumn{7}{c}{ Pomacea } \\
Variáveis & Média & Desvio padrão & Mínimo & Máximo & $\mathrm{N}$ & $\mathrm{N}$ válido \\
$\mathrm{SW} / \mathrm{SH}$ & 0,83 & 0,10 & 0,62 & 1,14 & 47 & 23 \\
$\mathrm{AW} / \mathrm{SH}$ & 0,57 & 0,05 & 0,50 & 0,69 & 47 & 17 \\
$\mathrm{Sph} / \mathrm{SH}$ & 0,12 & 0,06 & 0,02 & 0,27 & 47 & 17 \\
& \multicolumn{7}{c}{ Idiopyrgus } \\
$\mathrm{SW} / \mathrm{SH}$ & 0,40 & 0,05 & 0,25 & 0,50 & 63 & 23 \\
$\mathrm{AW} / \mathrm{SH}$ & 0,28 & 0,05 & 0,20 & 0,45 & 63 & 18 \\
& 0,52 & 0,41 & 0,23 & 6,62 & 309 & 244 \\
$\mathrm{SW} / \mathrm{SH}$ & 0,52 & 0,06 & 0,18 & 0,71 & 309 & 208 \\
$\mathrm{Sph} / \mathrm{SH}$ & 0,30 & 0.070 \\
\hline
\end{tabular}

O gênero Biomphalaria apresenta médias para altura e largura da concha de $5,45 \times 2,68 \mathrm{~mm}$, com altura da abertura de 1,77mm em média (Tabela 19 e Figura 93). O desvio padrão obtido não é próximo a 0 para $\mathrm{SH}$ e SW, mesmo com número de indivíduos analisados maior que 200 . 


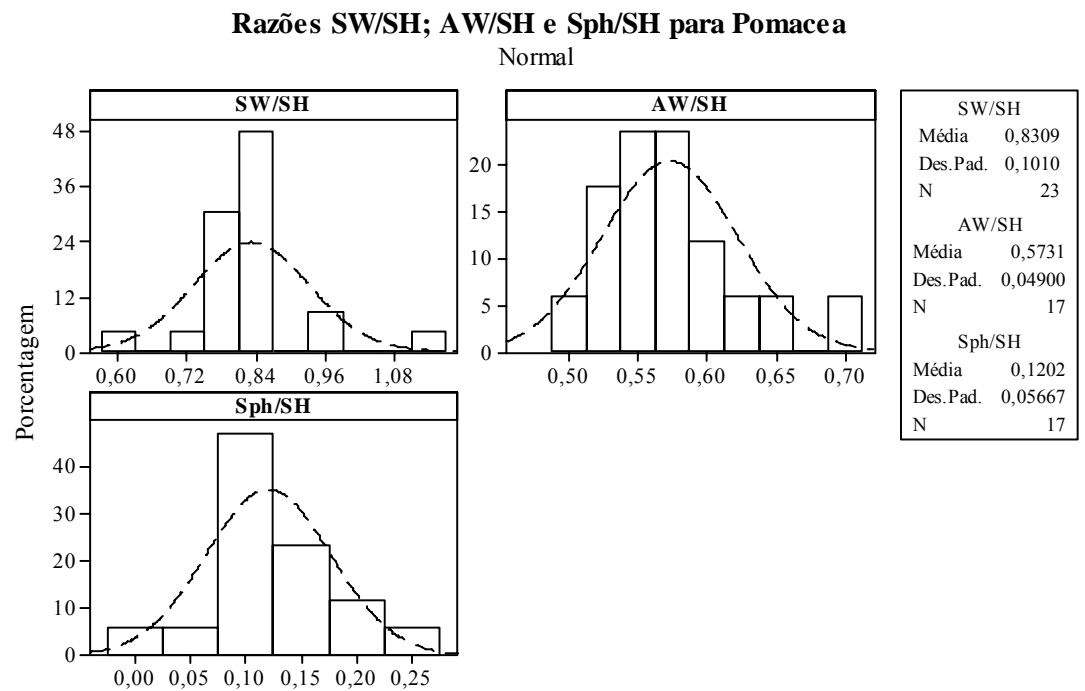
em perfil.

Figura 92 - Gráficos para as razões biométricas dos gastrópodes obtidos no bloco orientado analisado
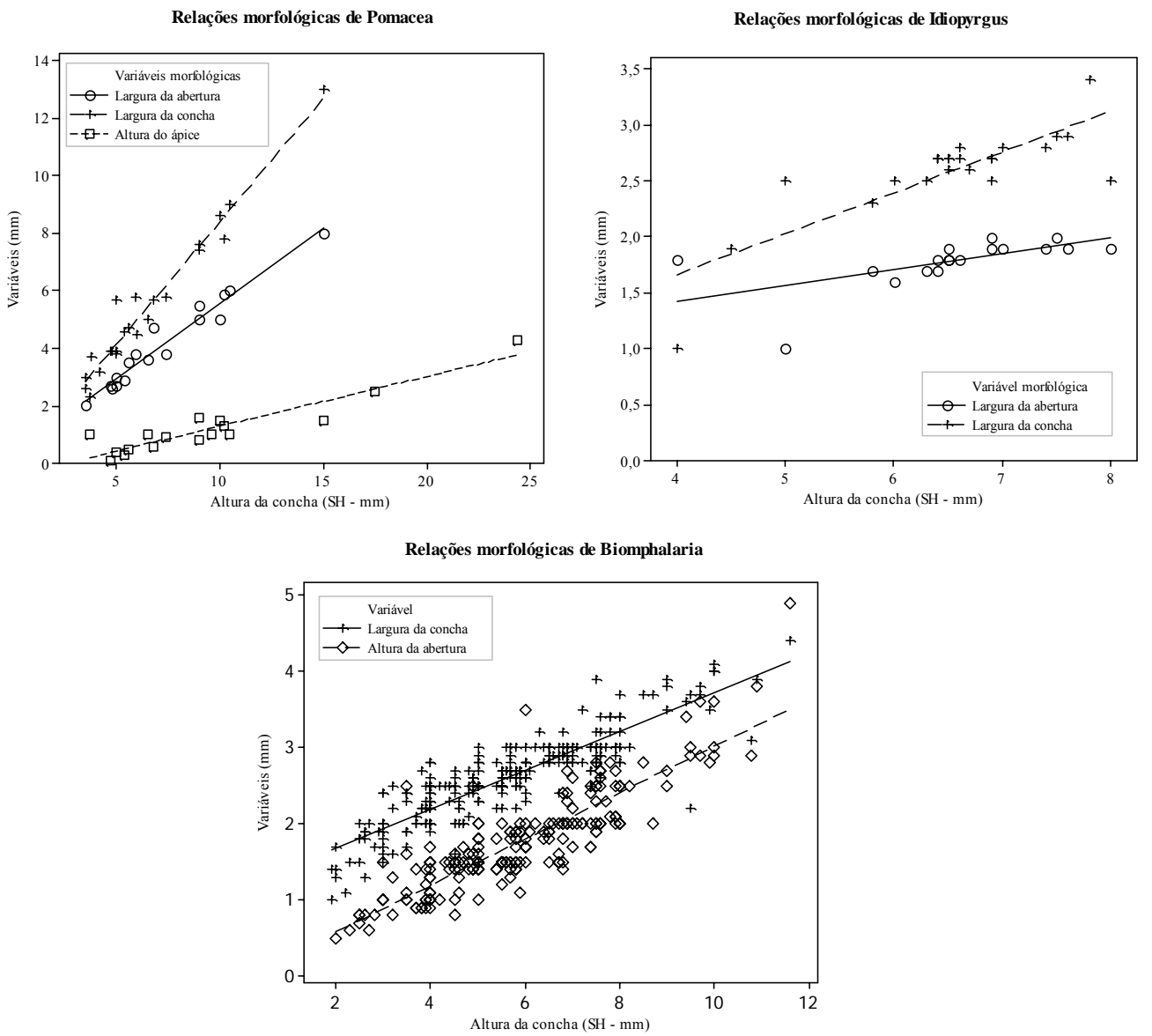

Figura 93 - Relações morfológicas das conchas de Pomacea, Idiopyrgus e Biomphalaria obtidas no bloco orientado analisado em perfil. 
As razões obtidas para SW/SH e Sph/SH são 0,52 e 0,30 respectivamente (Tabela 19). A razão SW/SH concentra-se entre 0 e 1 em quase $100 \%$ dos casos, enquanto $\mathrm{Sph} / \mathrm{SH}$ se distribui entre 0,18 e 0,45 , com moda em 0,27-0,30 (Figura 95).

Observando a distribuição da altura pela largura e altura da abertura e altura da concha de Biomphalaria (Figura 93) nota-se grande amplitude dos pontos em torno da linha de regressão.

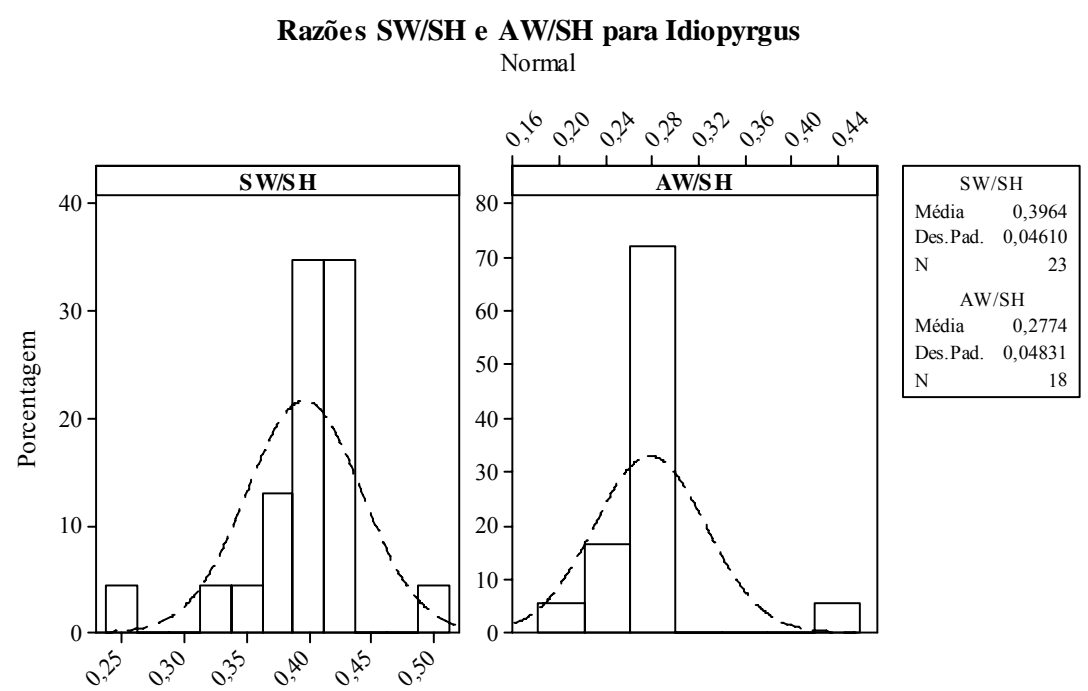

Figura 94 - Razões de largura da concha (SW) pela altura da concha (SH) e largura da abertura (AW) pela altura da concha do gênero Idiopyrgus obtidos no bloco orientado estudado em perfil.

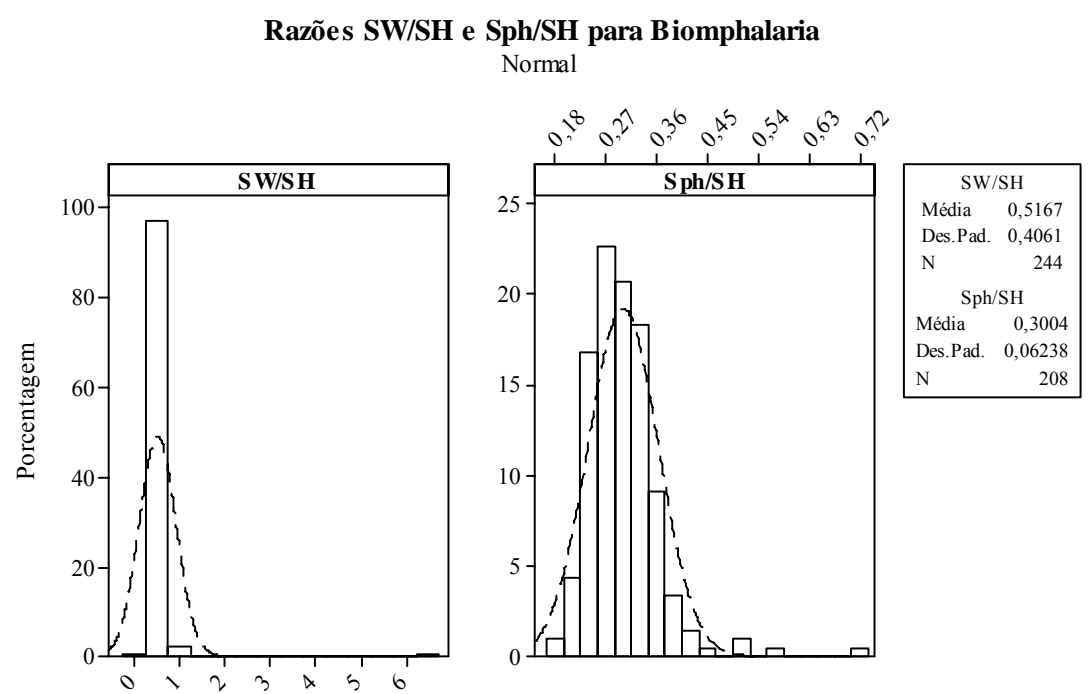

Figura 95 - Razões de largura da concha (SW) pela altura da concha (SH) e largura da abertura (Sph) pela altura da concha para indivíduos do gênero Biomphalaria obtidos no bloco orientado analisado em perfil. 
Observando os dados de altura dos indivíduos de Pomacea, Idiopyrgus e Biomphalaria, o gráfico obtido é semelhante ao da análise em planta (Figura 90 e 96), sendo a principal modificação o número total de indivíduos. Nota-se também que ocorre pequena variação nos tamanhos apresentados. Assim, nesta análise em perfil, também é observada a distribuição semelhante a normal para o gênero Biomphalaria.
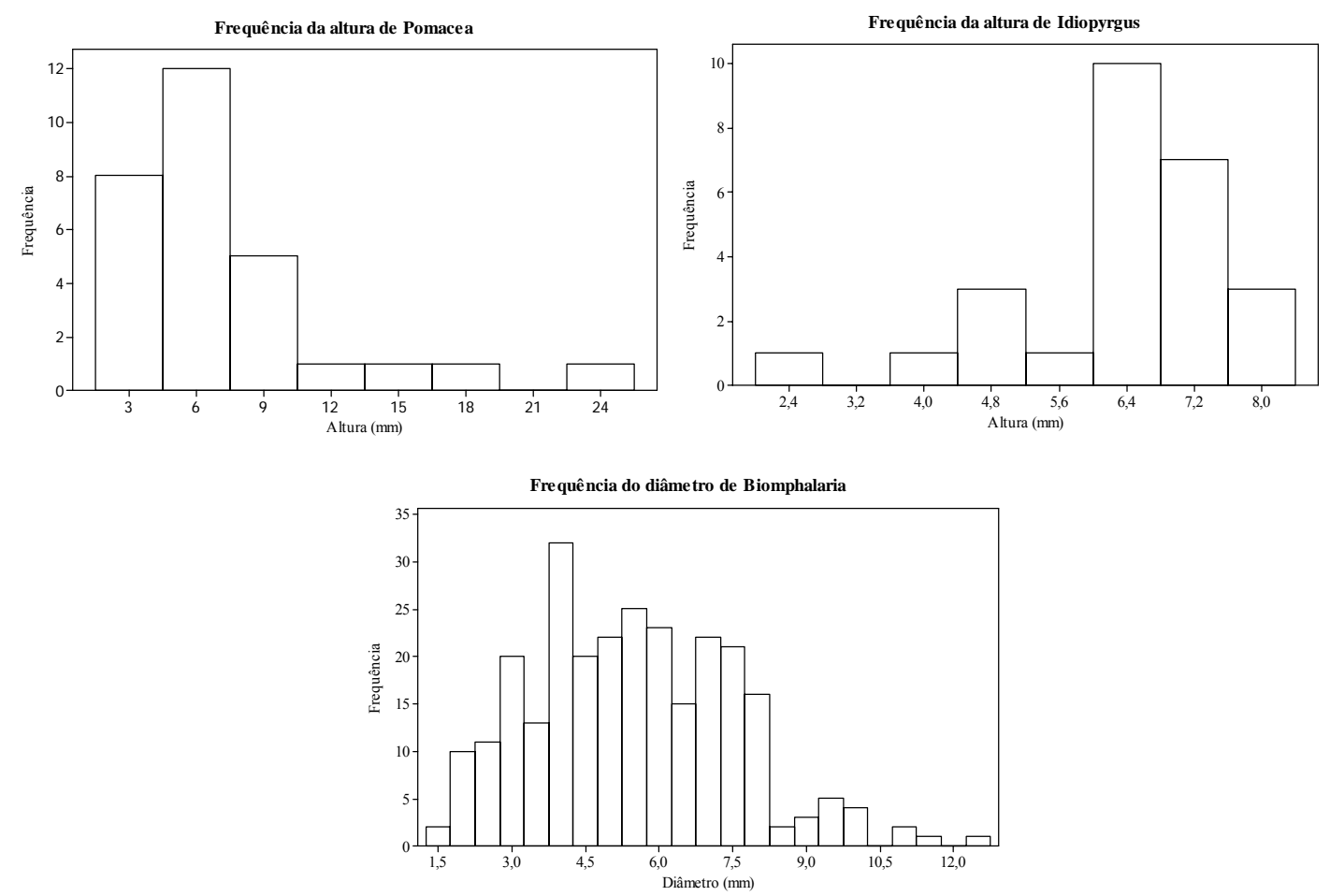

Figura 96 - Frequências da altura dos gêneros Pomacea e Idiopyrgus, e diâmetro de Biomphalaria , quando analisados em perfil na amostra.

\subsubsection{Considerações}

Os dados morfológicos dos gastrópodes analisados mostram que o gênero Pomacea apresenta indivíduos de maiores proporções quando observado em planta, provavelmente resultado de maior amostragem nesta perspectiva.

As relações descritas por Estebenet (1998), largura da concha - altura da concha $(\mathrm{SW} / \mathrm{SH})$, largura da abertura - altura da concha $(\mathrm{AW} / \mathrm{SH})$ e altura das primeiras espirais altura da concha-altura da concha $(\mathrm{Sph} / \mathrm{SH})$ para Pomacea canaliculata, que aumentam em relação ao crescimento das conchas também é comprovada para o gênero, sem distinção da 
espécie. Ou, isto prova que o gênero em estudo é da espécie Pomacea canaliculata, de acordo com identificação de Utida et al. (2007).

Não ocorre número suficiente de indivíduos da Família Hydrobiidae para realização desta análise no perfil. Idiopyrgus e Biomphalaria são pouco maiores no perfil, além dos resultados também serem semelhantes entre as análises em planta e perfil. Idiopyrgus não apresenta dados tão lineares quanto Pomacea em duas relações morfológicas, mas com o aumento da altura da concha há aumento discreto da largura da abertura e da concha.

Para as relações de Biomphalaria os dados apresentam-se mais dispersos, com menor definição de linearidade, muitos pontos sem modificação da variável com alteração da altura.

Há maior concentração de indivíduos de tamanhos menores para Pomacea, maiores para Idiopyrgus e de tamanhos médios para Biomphalaria na porção analisada, considerando a variação de tamanho observada.

A frequência de distribuição do diâmetro de Biomphalaria demonstra, nos dois tipos de análise, que sua população é semelhante à distribuição de indivíduos atuais (Utzinger et al. 1997; Utzinger \& Tanner, 2000).

Este dado sugere mortalidade em massa, pois reflete o tamanho de toda a população, mas não há indícios sedimentares que resultem em morte catastrófica. Isto demonstra a alteração do ambiente para um momento de extinção do depósito, provavelmente apenas pela redução drástica do volume de água, e mesmo que ainda houvesse condições hídricas para a sobrevivência dos gastrópodes, provavelmente este processo eliminaria as suas fontes alimentares.

Outra hipótese admitida é que a interação entre os gêneros observados pode ter afetado as distribuições dos gastrópodes, provocando a morte dos indivíduos de Biomphalaria em maior concentração. 
6.4. Índices ecológicos da paleofauna coletada no bloco orientado

6.4.1. Índices ecológicos da paleofauna obtida na análise tafonômica em planta

O táxon mais representativo no bloco analisado em planta é do gênero Idiopyrgus (Figura 97), mas ao longo das camadas analisadas sua proporção diminui, enquanto a proporção de Biomphalaria aumenta (Figura 98). Os bivalves encontrados representam juntos menos de 4\% do total dos moluscos encontrados (Figura 97). Os demais gastrópodes e fragmentos apresentam variação ao longo das camadas sem tendências marcadas.

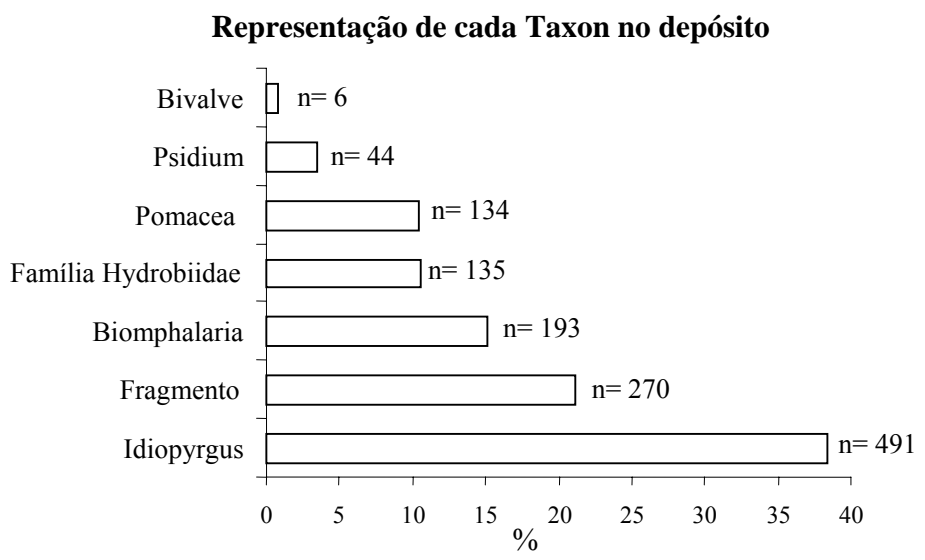

Figura 97 - Representação do total de moluscos encontrados na análise tafonômica em planta do bloco orientado da Mineração Calcário Xaraés.

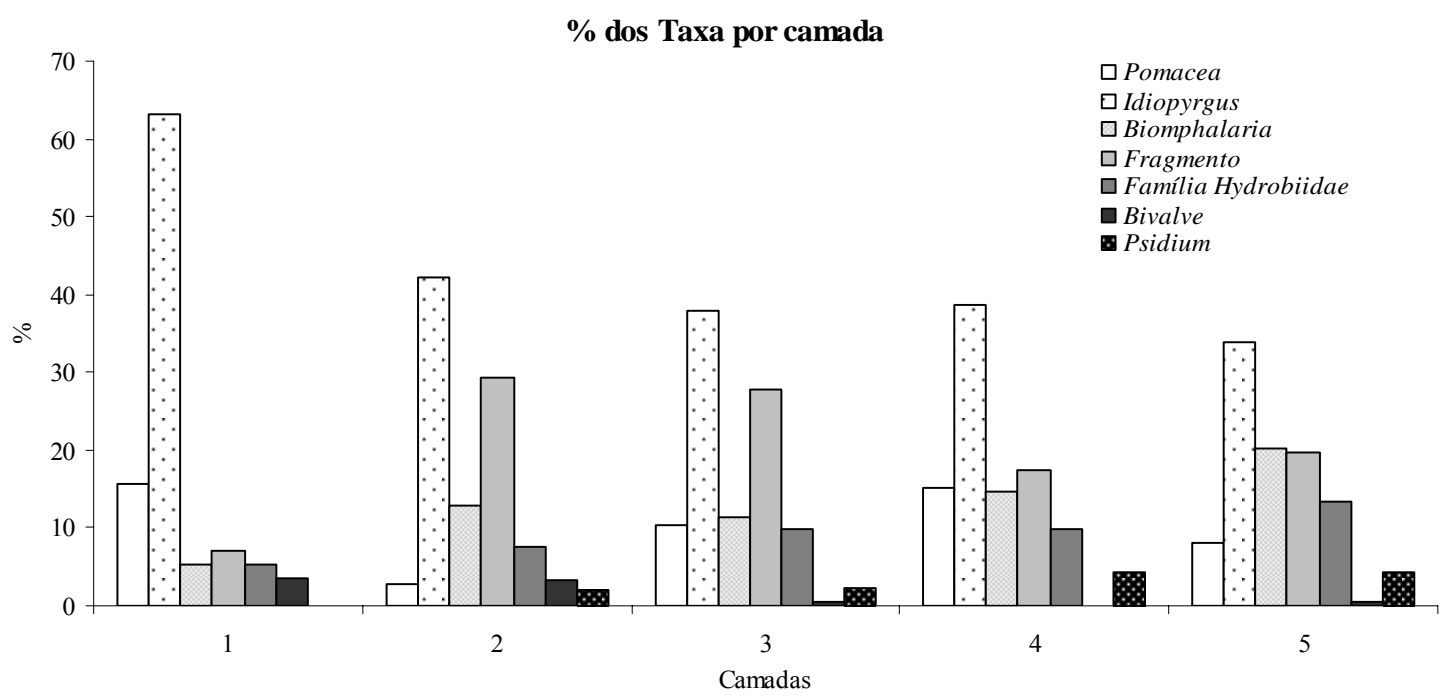

Figura 98 - Proporção de taxa por camada obtidas no bloco analisado em planta. 
Os índices ecológicos calculados para a análise em planta mostraram que a diversidade de espécies (H') entre as camadas é muito próxima, mas aumenta em direção a base da amostra. O mesmo ocorre com a proporção de indivíduos por espécie (E) (Tabela 21).

Isto reflete na dominância (D), há menor predomínio de algumas espécies em direção a base, no caso ocorre redução da proporção de indivíduos do gênero Idiopyrgus.

Tabela 21 - Índices ecológicos para os dados coletados nas camadas em planta do bloco orientado.

\begin{tabular}{|c|c|c|c|c|c|c|}
\hline \multicolumn{7}{|c|}{ Índices ecológicos } \\
\hline \multirow{6}{*}{ 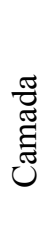 } & & $\mathrm{N}$ & $\mathrm{S}$ & Shannon (H') & Simpson (D) & Equitatividade (E) \\
\hline & 1 & 56 & 6 & 1,17 & 0,45 & 0,65 \\
\hline & 2 & 104 & 6 & 1,23 & 0,40 & 0,69 \\
\hline & 3 & 190 & 6 & 1,32 & 0,34 & 0,73 \\
\hline & 4 & 331 & 5 & 1,38 & 0,30 & 0,86 \\
\hline & 5 & 228 & 6 & 1,43 & 0,28 & 0,80 \\
\hline \multicolumn{2}{|c|}{ Total } & 1006 & 6 & 1,44 & 0,43 & 0,80 \\
\hline
\end{tabular}

6.4.2. Índices ecológicos da paleofauna obtida na análise tafonômica em perfil

$\mathrm{Na}$ análise em perfil o táxon mais representativo é o gênero Biomphalaria com quase $65 \%$ do total de bioclastos encontrados (Figura 99). O gênero de bivalve, Psidium, é representado por apenas 2 indivíduos, os gastrópodes que não puderam ser identificados representam menos e 5\%, enquanto os demais apresentam proporção aproximada (Figura 99).

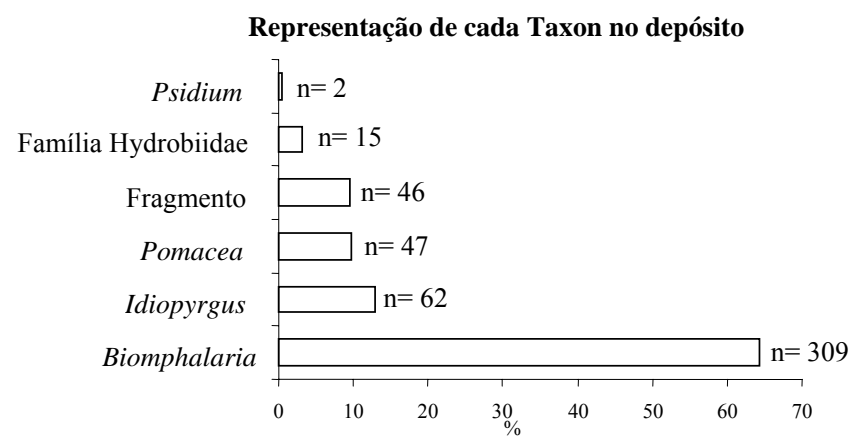

Figura 99 - Representação do total de moluscos encontrados na análise tafonômica em perfil do bloco da Mineração Calcário Xaraés. 
Para distribuição nos horizontes analisados a proporção de Biomphalaria varia de 50 a $70 \%$ de frequência. A proporção de Idiopyrgus e do gastrópode da Família Hydrobiidae cai em direção à base do bloco (Figura 100).

A frequência do gênero Pomacea e de fragmento no perfil varia sem tendências, aproximadamente na mesma proporção.

\section{$\%$ dos Taxa por horizonte}

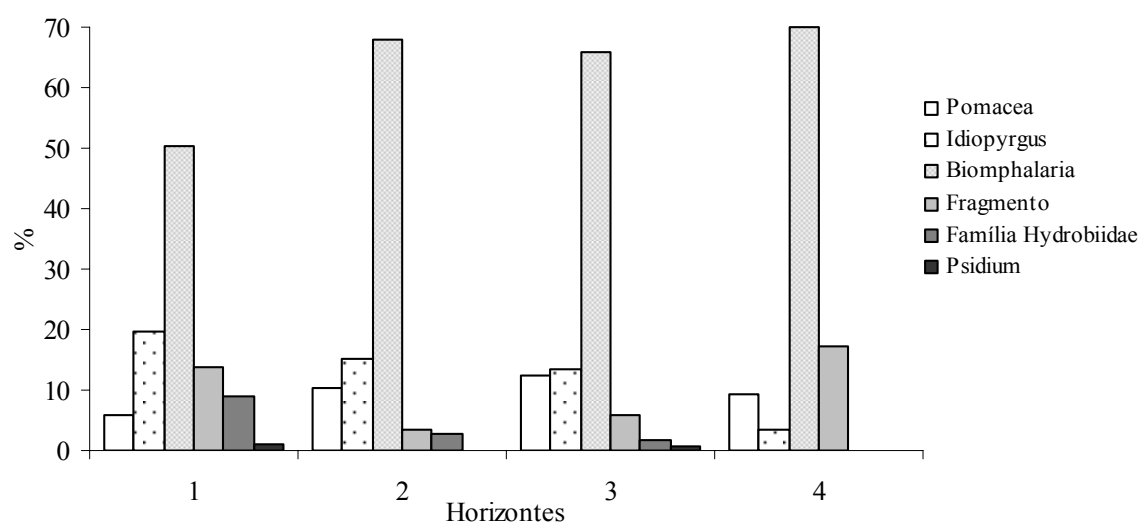

Figura 100 - Proporção de taxa por camada do bloco analisado em perfil.

Para os índices calculados a partir dos dados em perfil da análise tafonômica a diversidade em número de espécies ( $\left.\mathrm{H}^{\prime}\right)$ diminui em direção a base, assim como a equitatividade, já a dominância (D) entre as espécies aumenta em direção a base. No caso do perfil o gênero Biomphalaria é o mais dominante (Tabela 22). orientado.

Tabela 22 - Índices ecológicos para os dados coletados nas camadas analisadas em planta no bloco

\begin{tabular}{|c|c|c|c|c|c|}
\hline \multicolumn{6}{|c|}{ Índices ecológicos } \\
\hline & $\overline{\mathrm{N}}$ & $\mathrm{S}$ & Shannon $\left(\mathrm{H}^{\prime}\right)$ & Simpson (D) & Equitatividade (E) \\
\hline$\stackrel{\circlearrowright}{=} 1$ & 87 & 5 & 1,12 & 0,41 & 0,70 \\
\hline 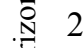 & 139 & 4 & 0,88 & 0,53 & 0,64 \\
\hline 둥 3 & 113 & 5 & 0,91 & 0,53 & 0,56 \\
\hline 4 & 96 & 3 & 0,52 & 0,73 & 0,48 \\
\hline Total & 435 & 5 & 0,9 & 0,54 & 0,56 \\
\hline
\end{tabular}




\subsubsection{Considerações}

A concentração de fósseis no bloco orientado muda quando observada em planta e em perfil. No entanto, isto não significa que a composição faunística muda ao longo da amostra, pois haveria necessidade de coleta de dados em maior extensão do depósito.

Os gastrópodes observados possuem diferentes morfologias, além de variar sua disposição no sedimento, possivelmente variando sua distribuição conforme a perspectiva de observação.

Esta comparação de tipos de análises mostra que, de acordo com o tipo de observação adotada, pode haver modificação das interpretações, por exemplo, a maior concentração de gastrópodes do gênero Biomphalaria, na análise em perfil, demonstra tendência a um ambiente menos úmido, já que são moluscos adaptados a condições temporárias, ou margens de sistemas aquáticos. Ao contrário, na análise em planta, a maior concentração do gastrópode não pulmonado Idiopyrgus, de hábito aquático, sugere ambiente mais úmido e maior volume de água.

Também sob efeito da amostragem os dados observados em perfil mostram índices de diversidade $\left(\mathrm{H}^{\prime}\right)$ menores que os obtidos para a análise dos resultados obtidos em planta. Há maior dominância (D) e consequentemente menor equitatividade de espécies para os dados em perfil.

Toma-se como resultado geral, pequenas variações de diversidade na porção analisada, com a presença de um ambiente úmido, com volume de água que permita o desenvolvimento dos gastrópodes aquáticos, mas com proximidade das margens do provável lago, devido à presença de Biomphalaria.

\subsection{Orientação dos gastrópodes}

A análise de direção preferencial foi feita em planta e em perfil no bloco orientado da Mineração Calcário Xaraés. Para a análise em planta 462 gastrópodes foram analisados, enquanto em perfil 81, considerando a orientação do ápice. 
A orientação dos bioclastos na análise em planta possui vetor médio de $248^{\circ}$, que indica, aproximadamente, oeste sudoeste, considerando $0^{\circ}$ como Norte. $\mathrm{O}$ vetor mediano de $245^{\circ}$ é influenciado por uma moda próxima a $190^{\circ}$ (Tabela 23).

A análise da direção do ápice dos gastrópodes em planta, do bloco extraído da Mineração Calcário Xaraés, mostra distribuição uniforme dos bioclastos, de acordo com o teste de Rayleigh (Figura 101). A probabilidade da direção preferencial, Teste Rayleigh (p), é inferior ao Teste Rayleigh (Z) obtido, sugerindo a rejeição de uma direção preferencial.

Para a análise em perfil, feita na face Norte do bloco, o vetor médio indica $62,61^{\circ}$, que equivale ao ângulo de inclinação da direção do ápice do bioclasto no perfil considerando o topo como $0^{\circ}$. Da mesma forma que a análise em planta, o Teste Rayleigh (p) de probabilidade é inferior ao Teste Rayleigh (Z) obtido (Tabela 23), excluindo assim, a hipótese de direção preferencial, apesar de visualmente haver certa tendência entre 0 e $150^{\circ}$ (Figura 101).

Apesar de não haver direção preferencial para a análise em planta e em perfil, os vetores médios das análises indicam mesma orientação quando referenciados (Figura 102). Isto evidencia uma relação entre as análises, ou seja, feita a análise em perfil ou em planta, os resultados não são alterados considerando o depósito homogêneo.

Tabela 23 - Teste de uniformidade para as direções do ápice dos gastrópodes do bloco orientado analisados em planta e em perfil da Mineração Calcário Xaraés.

\begin{tabular}{lll}
\hline \multicolumn{3}{c}{ Teste de Uniformidade - teste de Rayleigh } \\
\hline Índices & Planta & Perfil \\
\hline $\mathrm{n}^{\circ}$ de observações & 462 & 81 \\
Vetor médio $(\mu)$ & $248,058^{\circ}$ & $62,611^{\circ}$ \\
Magnitude do vetor resultante & 0,061 & 0,154 \\
Mediana & $245^{\circ}$ & $53^{\circ}$ \\
Parâmetro de concentração $\mathrm{k}$ & 0,123 & 0,311 \\
Variância Circular & 0,939 & 0,846 \\
Desvio Padrão Circular & $135,415^{\circ}$ & $110,917^{\circ}$ \\
Erro padrão da média & $30,749^{\circ}$ & $29,144^{\circ}$ \\
95\% Intervalo de confiança $(-/+) \mathrm{p} / \mu$ & $187,778^{\circ}$ & $5,476^{\circ}$ \\
& $308,338^{\circ}$ & $119,745^{\circ}$ \\
99\% Intervalo de confiança $(-/+) \mathrm{p} / \mu$ & $168,843^{\circ}$ & $347,529^{\circ}$ \\
Teste Rayleigh $(\mathrm{Z})$ & $327,273^{\circ}$ & $137,692^{\circ}$ \\
Teste Rayleigh $(\mathrm{p})$ & 1,733 & 1,91 \\
\hline
\end{tabular}


a

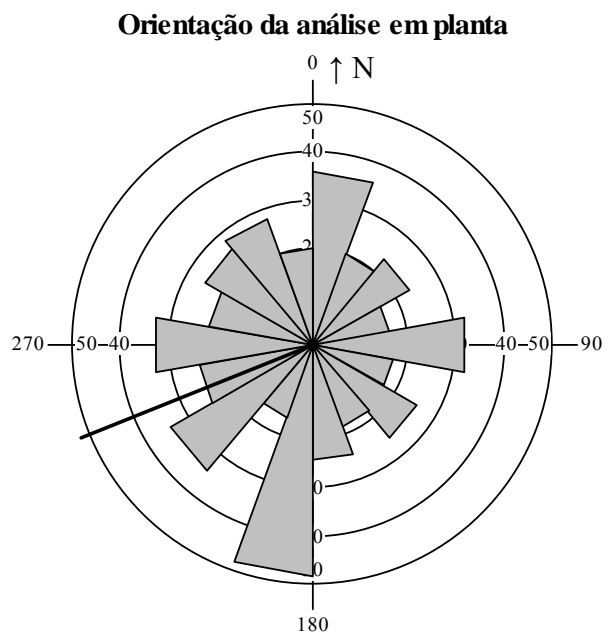

$\mathrm{b}$

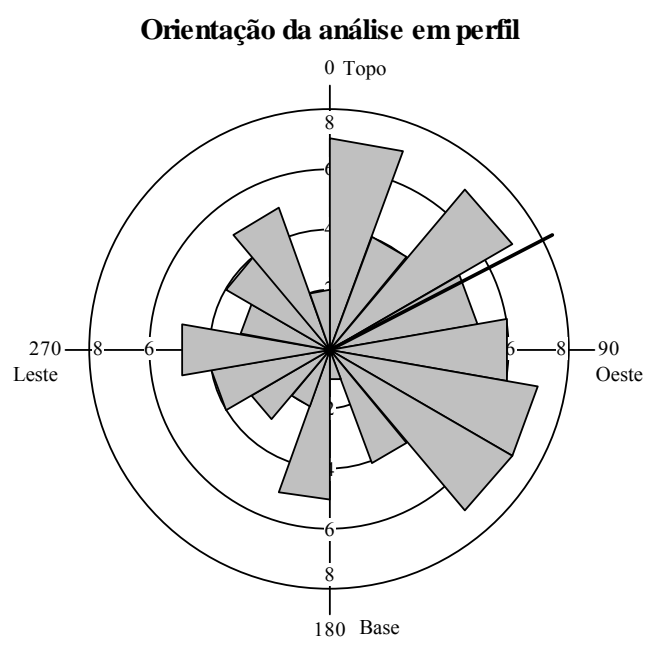

Figura 101 - Orientação dos gastrópodes na Mineração Calcário Xaraés. a) Histograma da orientação dos gastrópodes na análise em planta, $0^{\circ}$ representa o Norte e o vetor em preto indica o vetor médio. b) Histograma da orientação dos gastrópodes na análise em perfil, $0^{\circ}$ representa o Topo do perfil e o vetor em preto indica o vetor médio.

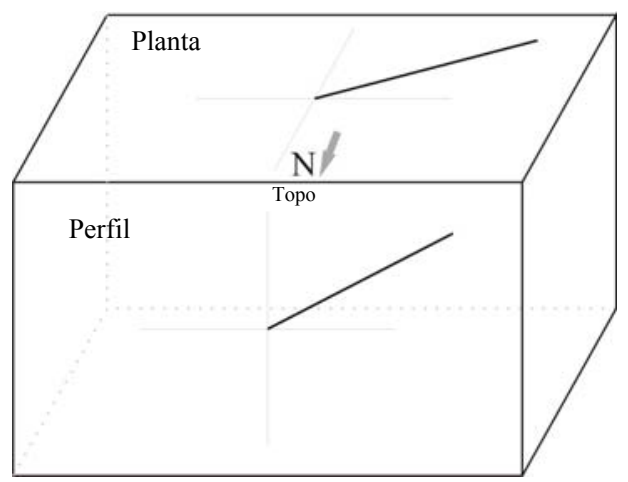

Figura 102 - Esquema do bloco analisado em planta e em perfil com os dados do vetor médio de cada análise.

6.6. Análise micropaleontológica

\subsubsection{Ostracoda}

Os ostracodes encontrados puderam ser identificados como Wolburgiopsis chinamuertensis, Ilyocypris, Cypridopsis, Cyprideis, Candona, Cypria, Darwinula e Pseudocandona. A maior parte destes indivíduos foram classificados principalmente através das impressões musculares, sendo necessária revisão taxonômica. Outras 5 carapaças inteiras não puderam ser identificadas, e foram denominadas de sp 1 a 6 . Muitos dos ostracodes lacustres são pouco conhecidos, restringindo as interpretações. 
Alguns ostracodes indeterminados não puderam ser descritos, a maior parte inteira, com incrustações carbonáticas sobre a carapaça, outros estavam fragmentados ou com muito sedimento incrustado. Outros exemplares, embora indeterminados puderam ser descritos, estando relacionados abaixo.

Família e Gênero indeterminados

Fam. et gen. Indet. 1

\section{Prancha II, 20; Prancha IV, 1; Prancha V, 15; Tabela 24}

Material e procedência: Ocorre uma valva esquerda na Mineração Calcário Xaraés na porção 2,18 , cinco carapaças inteiras no depósito 04 , e uma carapaça inteira no depósito 14.

Repositório: GP/5e-4068.50.3, GP/5e-4068.50.1, GP/5E-4086.5, GP/5E-4086.33, GP/5E-4068.25.3. O indivíduo da porção 2,18 não pode ser recuperado após o processo de MEV.

Dimensões: Cerca de $350 \mu \mathrm{m}$ de comprimento e $140 \mu \mathrm{m}$ de largura no centro da carapaça.

Descrição: É alongado, com extremidades arredondadas, liso e com poucos poros. As lamelas não se estendem ao longo da borda da carapaça, a anterior é mais longa em direção ao centro da carapaça, que a posterior. A carapaça direita é ligeiramente menor que a esquerda.

Fam. et gen. Indet. 2

\section{Prancha V, 14, Tabela 24}

Material e procedência: Ocorre uma carapaça inteira no depósito 14.

Repositório: GP/5E-4068.26.1.

Dimensões: Cerca de $360 \mu \mathrm{m}$ de comprimento, não foi possível calcular a largura pela imagem de MEV.

Descrição: É elipsóide e as carapaças direita e esquerda possuem aproximadamente mesmo tamanho. Ornamentação fracamente reticulada. 
Fam. et gen. Indet. 3

\section{Prancha IV, 5, Tabela 24}

Material e procedência: Ocorre no depósito 04 uma carapaça inteira.

Repositório: GP/5E-4068.50.3.

Dimensões: Cerca de $480 \mu \mathrm{m}$ de comprimento e maior largura na porção posterior de cerca de $180 \mu \mathrm{m}$.

Descrição: Tem forma semelhante a uma gota. A carapaça direita possui em cada extremidade duas projeções aciculares. Não possui ornamentação e apresenta poucos poros.

Fam. et gen. Indet. 4

\section{Prancha IV, 4, Tabela 24}

Material e procedência: No depósito 04 ocorrem 11 carapaças inteiras, 1 carapaça no depósito 14.

Repositório: GP/5E-4068-50.1, GP/5E-4086.5, GP/5E-4086.33.

Dimensões: Tem cerca de $400 \mu \mathrm{m}$ de comprimento e $200 \mu \mathrm{m}$ de largura máxima na porção central da carapaça.

Descrição: Ostracode oval, com maior largura na porção mediana da carapaça, apresentando linha lateral retilínea na região ventral e extremidades arredondadas. Possui ornamentação lisa e poucos poros.

Fam. et gen. Indet. 5

\section{Prancha III, 15 e 16; Prancha V, 9, Tabela 24}

Material e procedência: Fragmentos de ostracodes grandes são encontrados nos depósitos da Mineração Calcário Xaraés, na porção 1,38, e no depósito 07.

Repositório: GP/5E-4068.5.1, GP/5E-4082.13, GP/5E-4068.28.1.

Dimensões: Um dos fragmentos, com a carapaça quase completa, possui cerca de $1600 \mu \mathrm{m}$ de comprimento. 
Descrição: Aparentemente possuem carapaça lisa, mas apresentam-se bem alterados. Tem forma oval e coloração amarelada.

Tabela 24 - Ostracodes encontrados nos depósitos de micritos. Nesta tabela são contabilizadas apenas as valvas direitas, ou esquerdas, e indivíduos inteiros, para evitar a contagem em dobro do mesmo indivíduo.

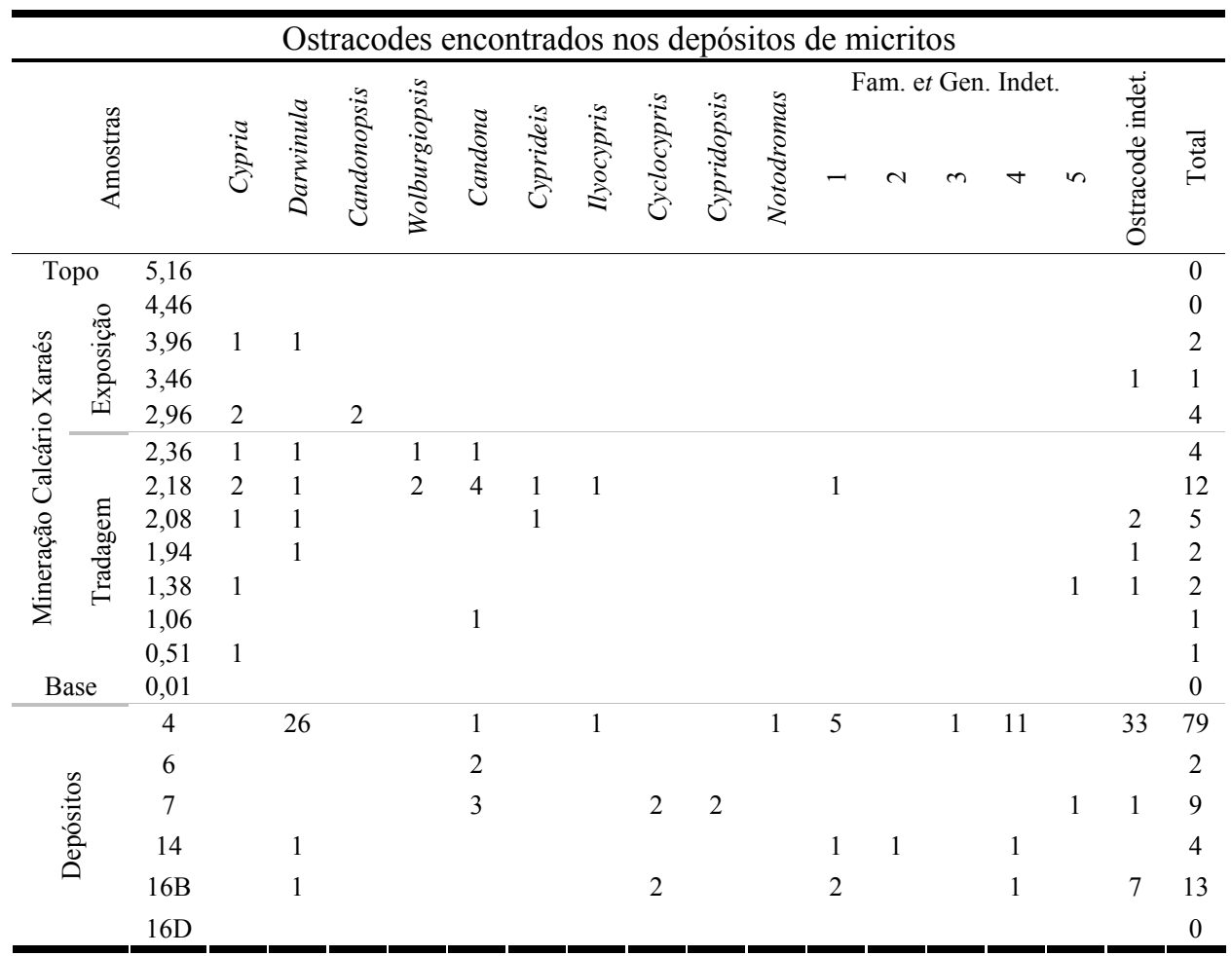

Candona

Cypria

Cyclocypris

Cyprydopsis

Darwinula

Candonopsis
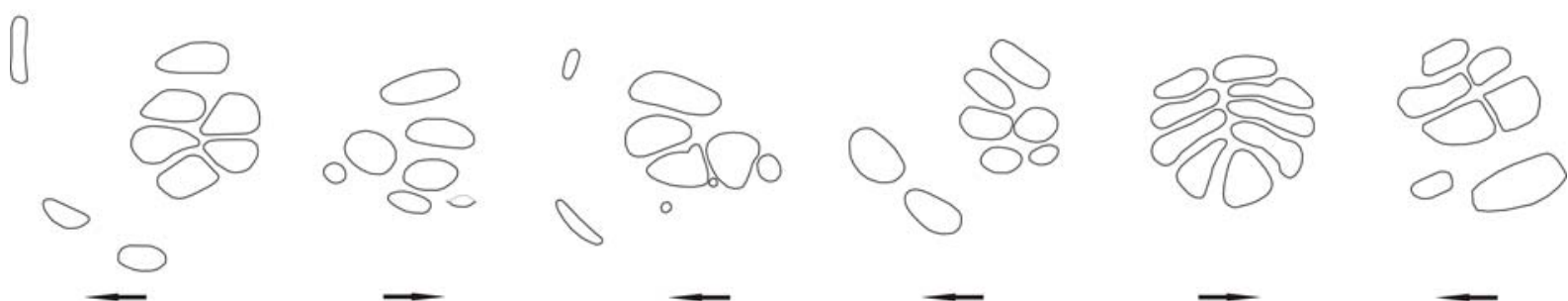

Figura 103 - Impressões musculares utilizadas para identificar os ostracodes. Modificado de Van Morkhoven (1963) e Gross (2008). 
Classe OSTRACODA Latreille, 1806

Ordem PODOCOPIDA Sars, 1866

Subordem PODOCOPINA Sars, 1866

Superfamília CYTHEROIDEA Baird, 1850

Família ILYOCYPRIDIDAE Kaufmann, 1900

Gênero Wolburgiopsis Uliana \& Musacchio, 1978

Espécie-tipo: Wolburgia? neocretacea Bertels, 1972

A atribuição em nível de família a este gênero é incerta. Ocorrem semelhanças com a Família Limnocytheridae em relação às impressões musculares e a presença de dois sulcos subverticais (Carmo et al., 2004).

Wolburgiopsis chinamuertensis (Musacchio, 1970)

1970 Wolburgia chinamuertensis Musacchio: p. 306-308, est. 1, figs 6-8.

\section{Prancha II, 13 e 14, Tabela 24}

Material e procedência: No ponto 2,36 do depósito da Mineração Calcário Xaraés, ocorre 1 valva direita e no ponto 2,18 duas valvas direitas e uma direita. Ambas as amostras obtidas por furo de trado.

Repositório: GP/5E-4068.4.3, GP/5E-4068.4.4, GP/5E-4078.25, após o MEV não foi possível recuperar as demais valvas.

Dimensões: Cerca de $350 \mu \mathrm{m}$ de comprimento e $160 \mu \mathrm{m}$ de largura.

Descrição: Tamanho diminuto, forma sub-retangular bissulcada. Possui ornamentação verrugosa com muitos poros. As margens nas porções anterior e posterior da carapaça apresentam depressão, que na margem anterior prolonga-se em direção ao centro da carapaça.

Observações: É um ostracode não marinho (Carmo et al, 2004). Descrita apenas para o Cretáceo Inferior da América do Sul. 
Subfamília ILYOCYPRIDINAE Kaufmann, 1900

Gênero Ilyocypris Brady \& Norman, 1889

Espécie-tipo: Cypris gibba Rhamdohr, 1808

Ilyocypris sp.1

\section{Prancha II, 15 e 16, Tabela 24}

Material e procedência: Representado por uma valva direita e uma esquerda, ocorre no depósito da Mineração Calcário Xaraés, no ponto 2,18 da amostragem por tradagem.

Repositório: GP/5E-4068.4.3, GP/5E-4078.26.

Dimensões: Cerca de $350 \mu \mathrm{m}$ de comprimento e $160 \mu \mathrm{m}$ de largura na porção central da carapaça.

Descrição: Morfologia alongada e subretangular nas linhas laterais, porções anteriores e posteriores da concha são arredondadas, apresenta ornamentação com forte reticulação e dois tubérculos bem pronunciados.

Observações: Ocorrem em ambientes límnicos a fracamente oligoalcalinos (Van Morkhoven, 1963; Sames, 2008). O gênero é cosmopolita, encontrado do Triássico ao Recente.

Ilyocypris sp. 2

\section{Prancha IV, 3, Tabela 24}

Material e procedência: Uma carapaça inteira é identificada no depósito 04.

Repositório: GP/5E-4068.50.2.

Dimensões: Cerca de $660 \mu \mathrm{m}$ de comprimento e $320 \mu \mathrm{m}$ de largura máxima e $280 \mu \mathrm{m}$ de largura mínima.

Descrição: É subretangular com bordas deprimidas nas extremidades, alongando-se para o centro da carapaça na região inferior-anterior, e na porção superior-posterior. Apresenta ornamentação reticulada menos pronunciada que o espécime anterior, e dois tubérculos de linhas suaves. 
Observações: Ocorrem em ambientes límnicos a fracamente oligoalcalinos (Van Morkhoven, 1963; Sames, 2008). O gênero é cosmopolita, encontrado do Triássico ao Recente (Moore, 1961).

Família NOTODROMADIDAE Kaufmann, 1900

Gênero Notodromas Liljerborg, 1853

Espécie-tipo: Cypris monacha O.F. Müller, 1776

Notodromas sp.

\section{Prancha IV, 10, Tabela 24}

Material e procedência: Encontrado somente um indivíduo inteiro no depósito 04 .

Repositório: GP/5E-4068.57.

Dimensões: Possui cerca de $320 \mu \mathrm{m}$ de comprimento e $250 \mu \mathrm{m}$ de largura.

Descrição: Tem forma ovalada, com a região ventral retilínea e é um pouco prolongado na região anterior. Possui ornamentação fracamente pontuada. O gênero é típico de água doce.

Observações: Indivíduos desta Família são tipicamente de água doce. O gênero é encontrado apenas no Recente (Moore, 1961).

Família CYPRIDIDAE Baird, 1845

Subfamília CYPRIDOPSINAE Kaufmann, 1900

Gênero Cypridopsis Brady, 1867

Espécie-tipo: Cypria vidua O. F. Muller, 1776; SD Brady \& Norman, 1889

Cypridopsis sp.

\section{Prancha V, 3 ao 7, Tabela 24}

Material e procedência: Representado por 2 valvas direitas, e 1 valva esquerda fragmentada, ocorrem no depósito 07. 
Repositório: GP/5E-4068.26.1.

Dimensões: Cerca de $150 \mu \mathrm{m}$ de comprimento e $100 \mu \mathrm{m}$ de largura máxima.

Descrição: O gênero Cypridopsis é reconhecido por suas impressões musculares segundo imagens de Gross (2008) (Figura 103). Apresenta 4 inserções musculares adutoras empilhadas, seguidas de mais duas inserções na porção posterior, a frente destas inserções. $\mathrm{Na}$ porção inferior, ocorrem duas inserções mandibulares alongadas. A carapaça é ovalada e inflada na porção central. A região posterior é alongada e deprimida nas margens, possui ornamentação pontuada e fracamente reticulada.

Observações: Espécies de Cypridopsis são nadadoras ativas, principalmente nas margens com vegetação de lagos. É um ostracode tolerante a condições oligoalcalinas (Namiotko et al., 2003). No depósito 07 a valva esquerda fragmentada possui os mesmos tipos de inserções musculares que Cypridopsis, mas a fragmentação impossibilita a descrição dos detalhes da morfologia. O gênero é cosmopolita, encontrado do Cretáceo ao Recente.

\author{
Família CYTHERIDAE \\ Subfamília CYTHERIDEINAE \\ Gênero Cyprideis Jones, 1857
}

Espécie-tipo: Candona torosa Jones, 1850

\title{
Cyprideis ? sp.
}

\section{Prancha II, 26, Tabela 24}

Material e procedência: Representado por uma valva direita na amostragem por tradagem, na porção 2,18, no depósito da Mineração Calcário Xaraés, e no mesmo depósito, no ponto 2,08 representado por um fragmento.

Repositório: GP/5E-4068.4.4.

Dimensões: Cerca de $520 \mu \mathrm{m}$ de comprimento e $290 \mu \mathrm{m}$ de largura máxima no centro da carapaça.

Descrição: Carapaça oval alongada. Ornamentada com pequenos furos na carapaça e um pequeno sulco vertical na região antero-dorsal. 
Observações: É semelhante ao ostracode descrito por Krstić (2005) do Plioceno superior da Península Balcânica do mesmo gênero. São encontrados em ambientes mesopolihalinos a pequenos lagos com alta salinidade (Van Morkhoven, 1963). Apesar desta identificação, há dúvidas se não seria um indivíduo jovem do gênero Wolburgiopsis. Encontrado do Mioceno ao Recente (Moore, 1961).

Superfamília CYPRIDOIDEA Baird, 1845

Família CANDONIDAE Kaufmann, 1900

Subfamília CANDONINAE Kaufmann, 1900

Gênero Candona Baird, 1845

Espécie-tipo: Cypris reptans Baird, 1835; SD Baird, 1846

\section{Candona sp.}

\section{Prancha II, 3 e 4, 6 e 7; Prancha II, 21 a 23; Prancha V, 8; Tabela 24}

Material e procedência: Na porção 2,18 do depósito da Mineração Calcário Xaraés, ocorrem 6 valvas, quatro valvas direitas e duas valvas esquerdas, no ponto 2,36, também da Mineração, ocorrem duas valvas direitas, no ponto 1,06 há uma valva esquerda. No depósito 04 ocorre uma carapaça inteira, em 06, uma valva direita e uma esquerda, e no depósito 07 ocorrem 2 carapaças inteiras, provavelmente de indivíduos jovens, e uma valva esquerda.

Repositório: GP/5E-4068.4.1, GP/5E-4068.4.2, GP/5E-4068.4.5, GP/5E-4068.7.1, GP/5E-4068.26.1, GP/5E-4068.50.2, GP/5E-4092.29, GP/5E-4078.7.

Dimensões: Cerca de $410 \mu \mathrm{m}$ de comprimento e $200 \mu \mathrm{m}$ de largura.

Descrição: Este gênero pode se identificado pelas impressões musculares da concha, típicas da Subfamília Candoninae (Figura 103), são cinco inserções adutoras, quatro delas agrupadas na primeira coluna, e duas na porção posterior, em frente a elas encontram-se duas inserções mandibulares na porção inferior e uma inserção frontal na porção superior. É uma concha pontuada, sem depressões ou tubérculos, apresentando-se em forma de rins ou subtrapezoidal.

Observações: É possível que haja indivíduos pertencentes ao gênero Pseudocandona, que diferem de Candona apenas nas partes moles (Van Morkhoven, 1963; Gross, 2008). 
Vivem na superfície da lama e principalmente em águas continentais (Gross, 2008), mas podem se adaptar a diversas condições ambientais (Davies \& Griffiths, 2005). Gross (op. cit.) descreveu ornamentação reticulada da carapaça de Candona, semelhante às encontradas, no ponto 2,36 há uma valva que apresenta morfologia externa muito parecida com a de Candona, no entanto, suas inserções musculares são diferentes, possuem dois pares de inserções adutoras paralelas, uma a frente e outra sobreposta a apenas uma das inserções frontais, há também duas inserções mandibulares. O gênero é cosmopolita, encontrado do Terciário ao Recente.

Gênero Candonopsis Vávra, 1891

Espécie-tipo: Candona kingsleyi Brady \& Robertson, 1870

Candonopsis sp.

\section{Prancha I, 17 e 18, Tabela 24}

Material e procedência: Ocorre na Mineração na porção 2,96, da área exposta, uma valva direita e uma esquerda, ambas fragmentadas

Repositório: Os espécimes não puderam ser recuperados.

Dimensões: Cerca de $650 \mu \mathrm{m}$ de comprimento.

Descrição: O gênero Candonopsis pode ser identificado pelas impressões musculares (Figura 103), ocorrem cinco inserções musculares adutoras, semelhantes a de Candona, mais uma grande inserção inferior, e a sua frente uma pequena. Apresenta vários poros marginais simples. O exemplar encontrado esta fragmentado impedindo maiores descrições.

Observações: O gênero Candonopsis é típico de ambientes de água doce (Van Morkhoven, 1963). É um gênero cosmopolita e encontrado apenas no Recente (Moore, 1961).

Subfamília CYCLOCYPRIDINAE Kaufmann, 1900

Gênero Cypria Zenker, 1854

Espécie-tipo: Cypris exculpta Fischer, 1854 


\section{Cypria sp.}

\section{Prancha I, 11, 12, 18, 19; Prancha II, 17, 18 e 19 e Prancha III, 13 e 14; Tabela 24}

Material e procedência: Ocorre no depósito da Mineração Calcário Xaraés em vários pontos: 3,96, uma valva direita fragmentada, 2,96, duas valvas, uma direita fragmentada e uma esquerda, 2,36, uma valva direita fragmentada, 2,18, duas valvas direitas e duas valvas esquerdas, e em 2,08, uma valva esquerda; no ponto 1,38, ocorre apenas uma valva esquerda, e no ponto 0,51 , representado por uma valva direita.

Repositório: GP/5E-4068.2.2, GP/5E-4068.4.3, GP/5E-4068.4.4, GP/5E-4068.4.5, GP/5E-4068.7.2, GP/5E-4078.7, GP/5E-4078.27.

Dimensões: Cerca de $400 \mu \mathrm{m}$ de comprimento e $190 \mu \mathrm{m}$ de largura na altura das inserções musculares.

Descrição: Reconhecido pelas impressões musculares (Figura 103), apresenta quatro ou três inserções musculares adutoras, seguidas de uma grande inserção, e duas pequenas inserções, às vezes ausentes. Possui forma trapezoidal com ornamentação reticulada e poros salientes distribuídos principalmente nas margens da carapaça.

Observações: Muito comum em águas continentais, vive em quase todos os pequenos corpos de água e canais. Prefere ambiente rico em plantas, e é um ostracode nadador. É cosmopolita e também pode ocorrer em águas salinas (Gross, 2008). Algumas espécies são indicativas de pouca movimentação do corpo de água ou corpos permanentes de água (Davies \& Griffiths, 2005). Pelas inserções musculares também é possível reconhecer outro indivíduo do gênero Cypria, no depósito da Mineração Calcário Xaraés na porção 2,96, mas com carapaça lisa e poros provavelmente diminutos, pois não é possível visualizá-los, possui cerca de $300 \mu \mathrm{m}$ de comprimento e $140 \mu \mathrm{m}$ de largura, possivelmente uma forma jovem. É um gênero cosmopolita e encontrado do Terciário ao Recente (Moore, 1961).

Genus Cyclocypris Brady and Norman, 1889

Espécie-tipo: Cypris globosa Sars, 1863

Cyclocypris sp. 
Material e procedência: Ocorrem no depósito 07 duas valvas esquerdas e uma direita, e no depósito 16B é representado por uma carapaça inteira e uma valva direita.

Repositório: GP/5E-4068.26.2, GP/5E-4068.29.1.

Dimensões: o indivíduo fragmentado possui $170 \mu \mathrm{m}$ de largura, e o indivíduo inteiro $150 \mu \mathrm{m}$ de comprimento e $70 \mu \mathrm{m}$ de largura, mesma proporção para a valva direita.

Descrição: O gênero Cyclocypris pode ser reconhecido por suas impressões musculares (Figura 103). Possui três inserções musculares adutoras em uma mesma coluna, seguidas na porção anterior por apenas uma inserção, a frente deste conjunto há duas inserções alongadas, na porção inferior a inserção mandibular e na porção superior a inserção frontal. Possui valvas infladas, subovaladas lateralmente, maior largura da carapaça próxima à porção central e porções terminais arredondadas. A valva do depósito 07 está fragmentada, e aparenta ter a maior largura deslocada para a região anterior da carapaça, os demais provavelmente são formas jovens.

Observações: Ocorre em ambientes de água doce a oligoalcalinas, ricos em vegetação. São ostracodes nadadores ativos (Van Morkhoven, 1963). Algumas espécies são indicativas de pouca movimentação do corpo de água ou corpos permanentes de água (Davies \& Griffiths, 2005). É um gênero cosmopolita e encontrado do Terciário ao Recente (Moore, 1961).

Superfamília Darwinuloidea Brady \& Normann, 1889

Família Darwinulidae Brady \& Norman, 1889

Gênero Darwinula Brady, \& Robertson, 1885 emend. Pinto \& Kotzian, 1961

Espécie- tipo: Polycheles stevensoni Brady \& Robertson, 1870

Darwinula sp.

Prancha I, 9, 10; Prancha II, 1, 2, 25; Prancha III, 3, 12; Prancha IV, 2; Prancha V, 13;

Prancha VI, 4; Tabela 24

Material e procedência: Ocorre no depósito da Mineração Calcário Xaraés, nas porções 3,96, representada por uma valva esquerda, 2,36, por uma valva esquerda, 2,18, por uma valva esquerda , 2,08, uma valva direita, 1,94, uma valva direita, e nos depósitos 04, com 
26 carapaças inteiras, no depósito 14, com uma carapaça inteira e 16B também com uma carapaça inteira.

Repositório: GP/5E-4068.2.2, GP/5E-4068.3.1, GP/5E-4068.3.3, GP/5E-4068.4.1, GP/5E-4068.4.4, GP/5E-4068.26.1, GP/5E-4068.29.2, GP/5E-4068.50.1, GP/5E-4068.50.2, GP/5E-4078.30.

Dimensões: Os indivíduos de maior tamanho variam de 415 a $460 \mu \mathrm{m}$ de comprimento e de 185 a $240 \mu \mathrm{m}$ de largura, os menores possuem 272 a $366 \mu \mathrm{m}$ de comprimento e 127 a $178 \mu \mathrm{m}$ de largura, sendo formas jovens.

Descrição: O gênero Darwinula é facilmente reconhecido por suas inserções musculares adutoras em forma de roseta, típicas do gênero (Figura 103). Possui carapaça lisa e subalongada, a extremidade posterior é arredondada e a porção anterior sofre afilamento na largura.

Observações: Pode ser encontrada em todos os ambientes de águas doce, é um gênero cosmopolita, mas rara nos trópicos. (Van Morkoven, 1963; Carmo et al., 2004; Gross, 2008). É um gênero cosmopolita e encontrado do Carbonífero ao Recente (Moore, 1961).

Ornamentações em carapaças fragmentadas

Fragmentos de ostracodes ocorrem em todos os depósitos, alguns exibindo ornamentações.

No depósito da Mineração Calcário Xaraés, no ponto 5,16 há um fragmento com ornamentação pontuada (Prancha I, 2), no ponto 3,96 ocorre um fragmento de ostracode com ornamentação reticulada e pontuada com poucos poros (Prancha I, 13), em 2,36 a ornamentação é reticulada com poros em forma de papilas (Prancha II, 8), semelhantes às descritas por Cabral et al. (2008), identificada como Globotalicypridea Cabral e Colin, possivelmente adaptada a condições mais salinas. Ainda no ponto 2,36 outros fragmentos apresentam fina reticulação (Prancha II, 10 e 11), às vezes formando pentágonos, ornamentação semelhante as encontradas por Gross (2008) em espécimes fêmeas de Candona. Um terceiro fragmento mostra ornamentação levemente pontuada no mesmo ponto (Prancha II, 9). 
No ponto 1,06 da Mineração há um fragmento com ornamentação reticulada pouco marcada, semelhante à descrita para Cypria (Prancha III, 18). Em 0,51 é observado um fragmento com ornamentação reticulada bem marcada semelhante à descrita anteriormente para Ilyocypris (Prancha III, 21).

\subsubsection{Estruturas esferoidais}

Com exceção da base do depósito da Mineração Calcário Xaraés, ponto 0,01, e o depósito 16D, são encontrados nos depósitos estruturas esféricas, descritas possivelmente como ovos de ostracodes, organismos do grupo dos Heliozoa e fungos. Não é possível definilas quando observadas em lupa, apenas em MEV é possível diferencia-las com precisão.

Algumas estruturas globulares são semelhantes aquelas descritas por Carmo (1998), Smith (1999) e Gobbo-Rodrigues (2002), e interpretadas como ovos de ostracodes.

As esferas descritas por Smith (1999), da Formação Santana na Bacia do Araripe, não são encontradas associadas as carapaças dos ostracodes, somente no mesmo depósito. Variam de 85 a $110 \mu \mathrm{m}$, algumas tem aparência enrugada, podem apresentar um ou dois buracos, resultado da eclosão dos ovos ou fragmentação (Figura 104).

As estruturas observadas em MEV são esferas sem buracos, a maior parte lisa, com diâmetros que variam entre 65 e $100 \mu \mathrm{m}$ (Figura 104 d.1; Prancha I, 14 e Prancha III, 19).

Smith (ops. cit.) também estudou ovos de ostracodes recentes, Darwinula stevensoni possui ovos alongados (Figura 104, c), semelhantes aos observados nos depósitos 04 e 14 (Figura 104 d.2; Prancha IV, 9 ; Prancha V, 16).

Estruturas esféricas com depressões ordenadas, de forma padronizada são observadas e relacionadas com a Subclasse Heliozoa (Figura 104 d.3; Prancha I, 1 e 8, Prancha IV, 6 e Prancha VI, 9), mas aparentam ter uma membrana que recobre o que deveriam ser as aberturas, que pode ser um recobrimento de carbonato que pode ter incrustado o organismo ainda em vida (Ruppert \& Barnes, 1996). 

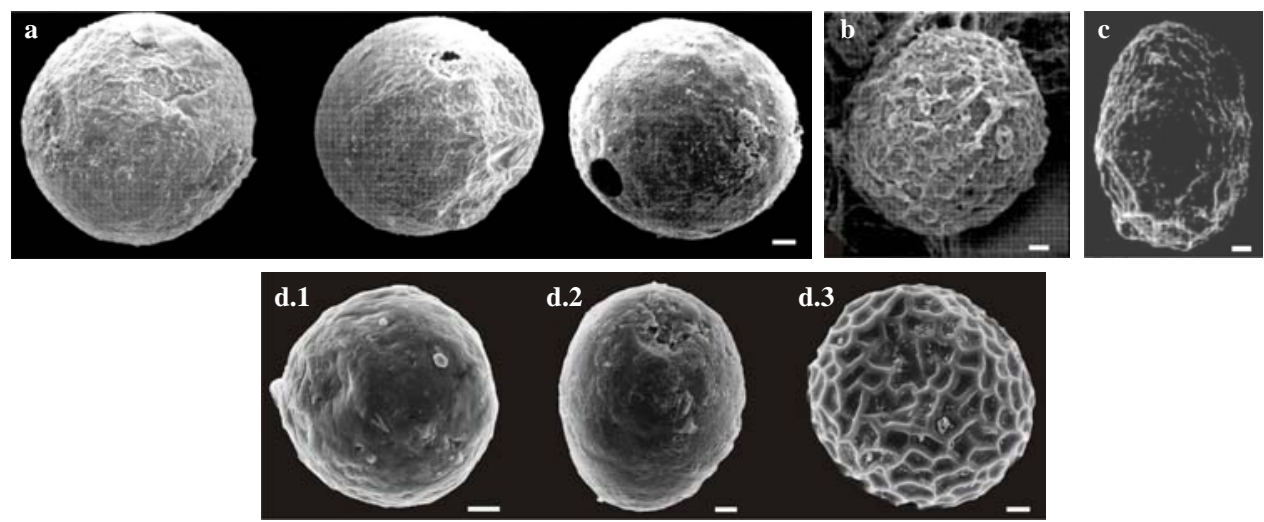

Figura 104 - Ovos de ostracodes estudados por Smith (1999). a) Esferas encontradas da Formação Santana. b) Ovos recentes do ostracode Heterocypris incongruens de espécimes criados em laboratório. c) Ovos recentes do ostracode Darwinula stevensoni de espécimes criados em laboratório. Extraído de Smith (1999). d) Estruturas interpretadas como: d.1) ovo esférico de ostracode Mineração Calcário Xaraés, ponto 1,06 do perfil; d.2) ovo alongado de ostracode, depósito 14; d.3) Heliozoa, depósito 16B. Escala $10 \mu \mathrm{m}$.

Segundo descrições de Moore (1954), indivíduos da Ordem Desmothoraca Hertwig \& Lesser, 1874, da Subclasse Heliozoa Haeckel, 1866, Classe Actinopoda, apresentam características semelhantes as observadas para as estruturas esféricas encontradas. São subglobulares com esqueleto reticulado contínuo, que pode ser de quitina com impregnações de sílica, ou raramente composto somente de sílica.

O esqueleto de quitina pode proporcionar melhor preservação que o composto por sílica em ambiente alcalino, sendo esta a provável composição das estruturas encontradas, mas ainda há possibilidade de haver precipitação de carbonato sobre as estruturas. Heliozoas são exclusivamente de água doce, a maior parte é de vida livre, frequentemente encontrados em lagos, lagoas e áreas alagadas (Moore, ops. cit.).

Estruturas esféricas ligadas a um pedúnculo, formando um acumulado de esferas são interpretadas como fungos, semelhantes a zoosporângios atuais (Figura 105 a e b). São encontradas em abundância no depósito 14 (Figura 105 c; Prancha V, 17 a 19). Considerando estas estruturas como fungos, elas podem ter se desenvolvido dentro do micrito após a extinção do depósito, ou serem atuais.

As estruturas globulares também foram inseridas na Coleção Científica do IGc-USP com as seguintes numerações: GP/5E-4070, GP/5E-4072, GP/5E-4073, GP/5E-4075, GP/5E4077, GP/5E-4080, GP/5E-4081, GP/5E-4082, GP/5E-4086, GP/5E-4092, GP/5E-4094, GP/5E-4095, GP/5E-4098, GP/5E-4100, GP/5E- 4068.1.1, GP/5E-4068.4.4, GP/5E-4068.7.1, GP/5E-4068.6.1, GP/5E-4068.25.2, GP/5E-4068.25.3, GP/5E-4068.29.1 e GP/5E-4068.49,2. 
a

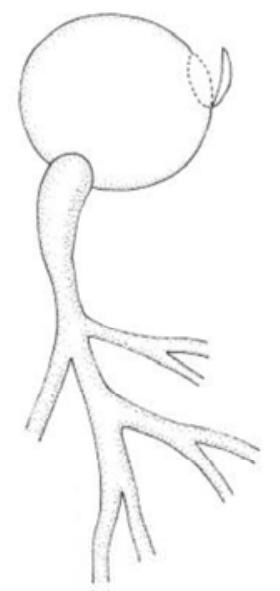

b

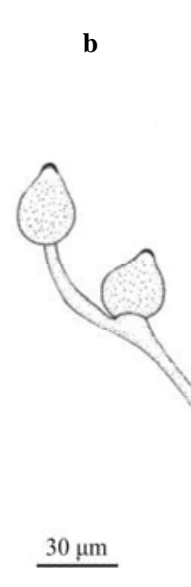

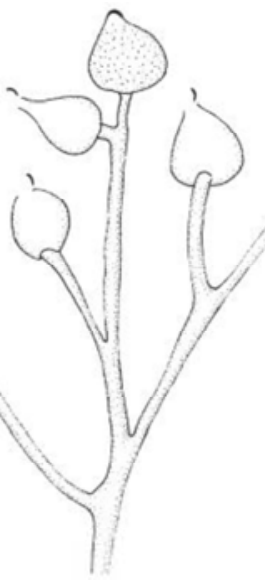

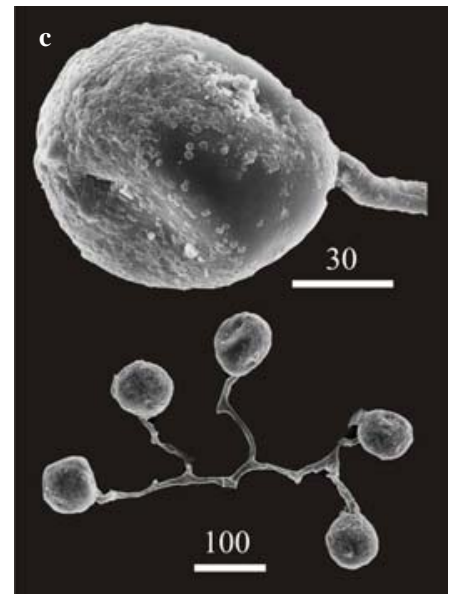

Figura 105 - Fungos atuais. a) Zoosporângio atual de Chytriomyces hyalinus Karling. b) Talo policêntrico com zoosporângios operculados de Nowakowskiella hemisphaerospora Shanor. Extraído de PiresZottarelli1 \& Rocha (2007). c) Estruturas esféricas ligadas a um pedúnculo encontradas no depósito 14.

\subsubsection{Charophytas}

A maior parte das carófitas vive em ambientes de água doce à salobra e ficam submersas e fixas no substrato. Há poucas dulciaquícolas, mas também podem ser marinhas, epífitas, viver em cascas de árvores e substratos. Ocorrem de regiões tropicais às polares e podem viver em simbiose com animais e vegetais (Mussa, 2004).

Os indivíduos da Ordem Charales (genericamente chamadas de stonewort em inglês) são utilizados como marcadores bioestratigráficos pela preservação das oogônias, também chamadas de girogônios, ou girogonites no caso dos fósseis, estrutura reprodutiva feminina, pois suas paredes celulares se calcificam enquanto vivas (Raven et al., 2002; Mussa, 2004).

Espécimes atuais vivem em águas alcalinas e podem variar normalmente de 15 a 30 $\mathrm{cm}$, mas também atingem $2 \mathrm{~m}$. Geralmente ocorre deposição de calcita nos girogonites e talos, mas podem ocorrer traços de aragonita e boa quantidade de magnésio. A estrutura dos talos das algas caráceas favorece a sedimentação das partículas em suspensão, resultando na clarificação das águas. As caráceas são uma das mais importantes fontes de alimento submerso (Tappan, 1980; Feist, 2005). 
Talos

Talos encontrados nos micritos apresentam cerca de 18 a 24 células corticais seqüenciais, do tipo haplostiquos completo, típicas do gênero Chara, que dão aspecto listrado a parte externa do fragmento (Prancha I, 16). Na Mineração, no ponto 1,38, ocorrem talos do tipo diplostiquo aulacantoso, com 9 células corticais secundárias, intercaladas por duas células corticais primárias (Figura 106). O talo possui cerca de $450 \mu \mathrm{m}$ de diâmetro e cada célula 35 $\mu \mathrm{m}$ de diâmetro. São encontrados fragmentos de talos de diversos comprimentos, desde micrométricos a centimétricos. O carbonato na porção externa do talo apresenta certo padrão na deposição, podendo ser o carbonato precipitado pela alga nos talos.

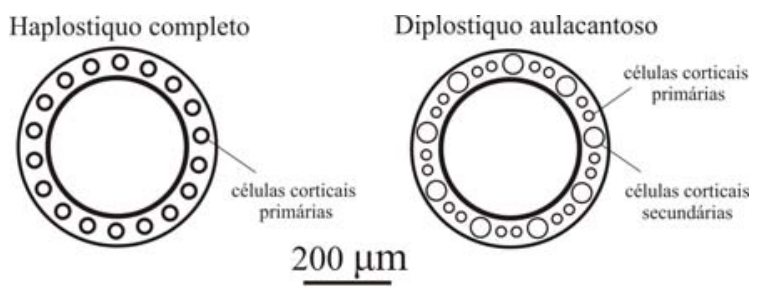

Figura 106 - Seções tranversais dos tipos de talos encontrados nos depósitos micríticos na planície da Serra da Bodoquena.

Há a presença no depósito 07 de um talo, ainda com os nós dos ramos e um fragmento de girogonite. O girogonite posiciona-se acima dos nós das ramificações (Figura 107).

O depósito da Mineração Calcário Xaraés apresenta talos de caráceas desde o ponto 0,51 até o topo do depósito (Pranchas I, 5, 16), apenas a base, que segue a deposição de oncólitos, não apresenta estruturas semelhantes. Na base ocorrem tubos carbonáticos, mas aparentemente sem ligação com as caráceas, são irregulares nas linhas laterais, não possuem os orifícios das células corticais, são lisos e possuem uma camada carbonática uniforme e sem porosidade (Prancha III, 24). Do ponto 1,94 a 1,06 da Mineração, os talos não estão bem preservados. No ponto 4,46 estão bem calcificados. Nos depósitos 04, 06, 07 e 16D também ocorrem talos de caráceas.

Na Mineração a partir do ponto 2,18 até o topo ocorrem fragmentos de talos vegetais, mas sem características de caráceas, apresentam aparência de desidratação. É possível que sejam de algas caráceas, mas por má preservação ou deposição dos fragmentos antes da 
precipitação carbonática os talos não foram bem preservados. Estes fragmentos vegetais também ocorrem nos depósitos 06, 07 e 16B.

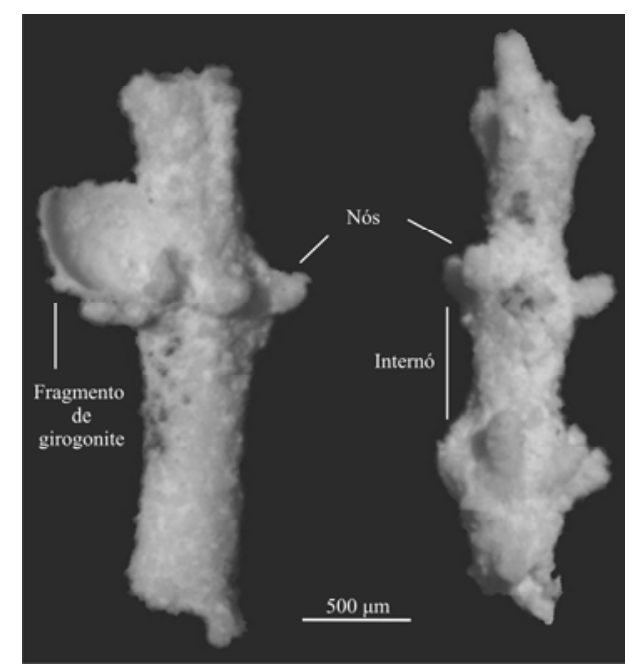

Figura 107 - Talos encontrados no depósito 07. Os talos apresentam os nós dos ramos, talo da direita possui parte de um girogonite.

\section{Girogonites}

Os girogonites encontrados pertencem ao gênero Chara Linnaeus, 1753, segundo classificação de Feist (2005). Os espécimes analisado serão depositados na coleção paleontológica do Instituto de Geociências da Universidade de São Paulo.

Filo Charophyta Migula, 1897

Classe Charophyceae Smith, 1938

Ordem Charales Lindley, 1836

Subordem Charinae Feist \& Grambast-Fessard, 1991

Família Characeae Agardh, 1824

Subfamília Charoideae Braun in Migula, 1897

Chara Linnaeus, 1753 
Todos os girogonites apresentam as características da Família Characeae: 5 células espirais sinistrais espiraladas, contínuas no ápice, a junção consiste em uma linha interrompida, onde uma das espirais se liga as demais.

As características do gênero Chara também são identificadas nos girogonites estudados, possuem ápice psilocharoide, depressão periapical ausente, convexo, nódulos apicais ausentes, e as porções finais das células apicais são mais largas (Figura 108). Em geral são elipsóides a cilindróide, alguns bem alongados. Os girogonites possuem de 10 a 12 células espirais em vista lateral.
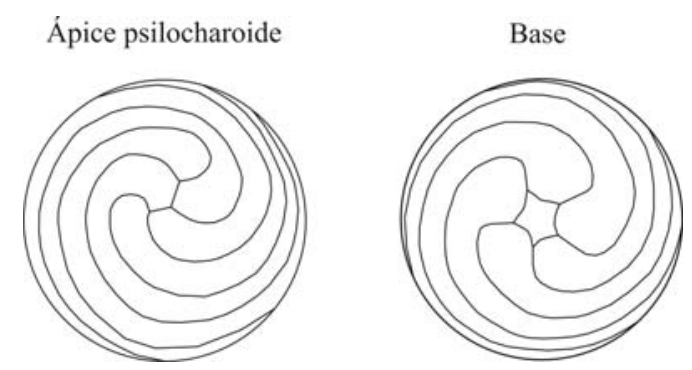
escala.

Figura 108 - Morfologia dos indivíduos do gênero Chara encontrados nos depósitos em estudo. Sem

Quatro variedades morfológicas de Chara foram identificadas e estão descritas no Quadro 01. Estes girogonites provavelmente pertencem a mesma espécie, e as variedades morfológicas podem ser resultados de variações ambientais, por exemplo, $\mathrm{pH}$ e temperatura da água, ou variações ecológicas, como a idade da alga que produziu o girogonite, ou tamanho da população de algas, que poderia afetar seu desenvolvimento.

As ocorrências de Chara restringem-se aos pontos do depósito da Mineração Calcário Xaraés 2,18, 2,08 e 1,94, e nos depósitos 04, 06, 07 e 16D. No depósito da Mineração no ponto 2,18 e 07, em maior quantidade, ocorre apenas Chara forma 4 (Prancha II, 24 e Prancha V, 10 a 12). Nos pontos 2,08 e 1,94 da Mineração ocorre apenas Chara forma 3 (Prancha III, 5 a 7, e 11), e em 16D há apenas um girogonite de Chara forma 2 (Prancha VI, 10). Nos depósitos 04 e 06 ocorrem Chara forma 1, 2 e 3, em ambos os depósitos Chara forma 3 ocorre com maior frequência (Prancha IV, 7, 8, 17, 18 e 19) (Tabela 25).

Muitos girogonites apresentam incrustações carbonáticas, impedindo sua identificação. Fragmentos de girogonites aparecem no depósito da Mineração Calcário Xaraés nos pontos 5,16 e 4,46 em pequena quantidade. 
Os girogonites foram incluídos na Coleção Científica com a seguinte numeração: Chara: 4068.3.3, 4068.4.2, 4068.6.3, 4068.25.2, 4068.28.2, 4068.28.1, 4068.33, 4068.51, 4068.52, 4068.53, 4068.54; forma 1: 4068.6.1, 4068.55; forma 2: 4068.6.3, 4068.29.3; forma 3: 4068.3.1, 4068.3.2, 4068.6.1, 4068.6.3, 4068.56.; forma 4: 4068.4.2 (Anexos F, G e H).

Quadro 01 - Variações morfológicas do gênero Chara encontrado nos depósitos de micritos da planície da Serra da Bodoquena.

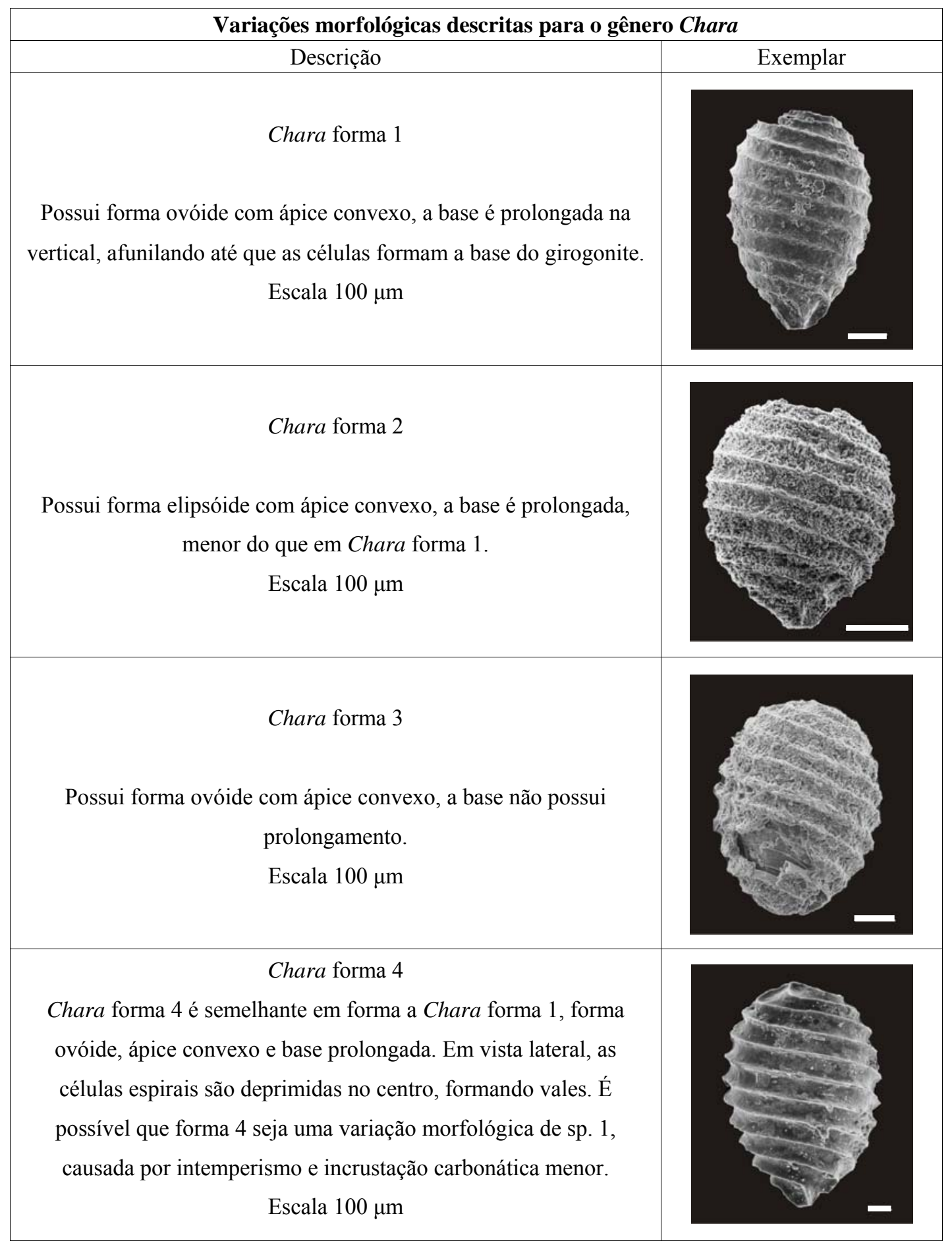


Tabela 25 - Ocorrências das variações morfológicas de Chara nos depósitos de micritos da planície da Serra da Bodoquena. Indet.: girogonites não identificados.

\begin{tabular}{cccccrrr}
\hline \multicolumn{6}{c}{ Ocorrências das variações morfológicas de Chara } \\
\hline \multicolumn{2}{c}{ Depósitos } & formas 1 & 2 & 3 & 4 & Indet. & Total \\
\hline Mineração & 2,18 & & & & 2 & 1 & 3 \\
Calcário & 2,08 & & & 2 & & 1 & 3 \\
Xaraés & 1,94 & & & 1 & & 3 & 4 \\
\hline \multirow{5}{*}{ Depósitos } & 04 & 2 & 1 & 3 & & 10 & 16 \\
& 06 & 2 & 3 & 7 & & 3 & 15 \\
& 07 & & & & 11 & 9 & 20 \\
& $16 \mathrm{D}$ & & 1 & & & & 1 \\
\hline
\end{tabular}

\subsubsection{Moluscos}

A maior parte dos moluscos encontrados na peneira de $0,5 \mathrm{~mm}$ já foram descritos, entre eles Biomphalaria, Pomacea, Idiopyrgus, indivíduos da Família Hydrobiidae, Acrobis e Psidium (Tabela 26). São indivíduos jovens, não observados na análise de macrofósseis por seu tamanho diminuto. Alguns gastrópodes não puderam ser identificados, por estarem recobertos por carbonato ou possuírem afinidades com mais de uma família (Prancha I, 4, 6 e 15; Prancha III, 10; Prancha IV, 20 e 21; Prancha V, 22, 23 e 24; Prancha VI, 1, 2 e 11).

No depósito da Mineração Calcário Xaraés indivíduos jovens de Biomphalaria (Prancha I, 7) ocorrem em quase toda a porção de micritos, com exceção dos três pontos da base (Tabela 26). O gênero Acrobis ocorre entre os pontos 2,96 e 1,94 (Prancha III, 8 e 9). Os indivíduos da Família Hydrobiidae e Idiopyrgus (Prancha I, 3), ocorrem em abundância somente no topo do depósito da Mineração, e indivíduos jovens do gênero Pomacea em menor quantidade. Os gastrópodes não identificados ocorrem entre nos pontos da porção exposta 5,16,4,46, 3,46 e 2,96, e na porção obtida por tradagem, nos pontos 2,08 e 1,94 (Prancha III, 10).

Os depósitos 04 e 06 são os que apresentam maiores concentrações de indivíduos da Família Hydrobiidae, Biomphalaria, Acrobis e Psidium (Prancha IV). O depósito 04 também possui indivíduos da Família Charopidae, Família Ancylidae e Subordem Elasmognata (Prancha V, 11, 14 e 15), e o depósito 06 um indivíduo da Família Subulinidae, Subfamília Subulininae e dois gastrópodes não identificados (Prancha IV, 20 a 23), mas é possível que sejam indivíduos recentes adicionados ao depósito por processos intempéricos. Alguns apresentam coloração e estão bem preservados. 
O depósito 14 possui 23 indivíduos da Família Hydrobiidae, 3 Acrobis e 7 indivíduos não identificados (Prancha V, 20 a 24).

Nos depósitos 16B e 16D ocorrem apenas indivíduos do gênero Biomphalaria e gastrópodes que não puderam ser identificados (Prancha VI, 1, 2, 11 e 12). Os moluscos também foram incluídos na Coleção Científica do IGc-USP (Anexos F, G e H).

Tabela 26 - Moluscos encontrados nos micritos da planície da Serra da Bodoquena.

\begin{tabular}{|c|c|c|c|c|c|c|c|c|c|c|c|c|c|}
\hline & & $\mathrm{Mo}$ & lusc & os e & con & trad & s n & $\mathrm{s} \mathrm{mi}$ & crit & & & & \\
\hline 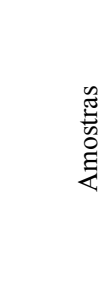 & & 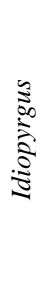 & 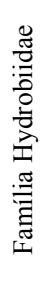 & $\begin{array}{l}\frac{a}{0} \\
\frac{0}{0} \\
\frac{0}{0} \\
\frac{0}{0}\end{array}$ & $\begin{array}{l}\tilde{0} \\
\frac{0}{0}\end{array}$ & 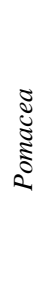 & 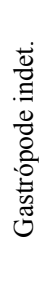 & 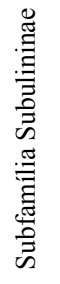 & 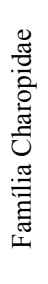 & 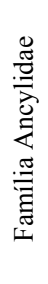 & 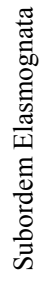 & 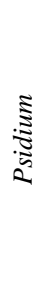 & స్ \\
\hline Topo & 5,16 & 6 & 18 & 5 & & 1 & 1 & & & & & & 31 \\
\hline$\stackrel{乛}{2}$ & 4,46 & 1 & 1 & 16 & & 2 & 4 & & & & & & 24 \\
\hline & 3,96 & & & 7 & & & & & & & & & 7 \\
\hline चี & 3,46 & & & 16 & & & 2 & & & & & & 18 \\
\hline $\begin{array}{ll}x & x \\
.0 & 1\end{array}$ & 2,96 & 1 & & 7 & 2 & & 3 & & & & & & 13 \\
\hline 氖 & 2,36 & & 1 & 3 & 4 & & & & & & & & 8 \\
\hline లే & 2,18 & & 1 & 4 & 4 & & & & & & & & 9 \\
\hline हี & 2,08 & & & 5 & 7 & & 1 & & & & & & 13 \\
\hline 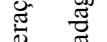 & 1,94 & & & & 3 & & 1 & & & & & & 4 \\
\hline 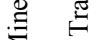 & 1,38 & & & 2 & & & & & & & & & 2 \\
\hline & 1,06 & & & & & & & & & & & & 0 \\
\hline & 0,51 & & & & & & & & & & & & 0 \\
\hline Base & 0,01 & & & & & & & & & & & & 0 \\
\hline & 4 & & 29 & 21 & 39 & & & & 1 & 2 & 1 & 2 & 95 \\
\hline o & 6 & & 52 & 16 & 18 & & 2 & 1 & & & & 2 & 91 \\
\hline 苟 & 7 & & & 5 & & & & & & & & & 5 \\
\hline о̆ & 14 & & 23 & & 3 & & 7 & & & & & & 33 \\
\hline & $16 \mathrm{~B}$ & & & 1 & & & 7 & & & & & & 8 \\
\hline & $16 \mathrm{D}$ & & & 4 & & & 1 & & & & & & 5 \\
\hline
\end{tabular}

\subsubsection{Estruturas aciculares}

São encontrados nos depósitos 06, e na Mineração Calcário Xaraés, nos pontos 2,08 e 2,18, (Pranchas II, 12 e Prancha IV, 16) estruturas aciculares, com base tripartida, sulcada externamente em cada eixo e com alguns poros visíveis, medindo entre 400 e $500 \mu \mathrm{m}$. Sugere-se que sejam estruturas corporais de invertebrados, como espículas de poríferas de água doce.

Espículas de poríferas podem ser compostas de calcita ou sílica opalina (Moore, 1955). Por tratar-se de um ambiente alcalino, é provável que as estruturas sejam compostas de 
calcita, pois a sílica não é estável nestes ambientes, ou estarem recobertas por carbonato, o que possibilitaria sua preservação.

As estruturas aciculares foram incluídas na Coleção Científica do IGc-USP com a seguinte numeração: GP/5E-4078, GP/5E-4086, GP/5E-4087, GP/5E-4092, GP/5E-4068.4.1 e GP/5E-4068.6.2.

\subsubsection{Oncólitos}

Na porção abaixo da base do depósito da Mineração Calcário Xaraés ocorrem grandes oncólitos (Figura 14). Pequenos grãos foram encontrados nas porções obtidas por tradagem da base da Mineração Calcário Xaraés, desde 0,01 até o ponto 1,06. Estes grãos encontram-se revestidos por poucas camadas carbonáticas, semelhante a dos oncólitos, com até $2000 \mu \mathrm{m}$ (Prancha III, 20, 22, 23 e 25).

Estes pequenos grãos revestidos por carbonato não atingiram tamanhos semelhantes aos observados para os oncólitos, possivelmente por mudança no paleoambiente. Infelizmente não foram obtidas amostras abaixo do nível com oncólitos, impedindo maiores interpretações.

6.6.7. Índices ecológicos da paleofauna coletada na análise micropaleotológica

A partir da análise de microfósseis foram calculados índices ecológicos referentes à diversidade (Shannon-Weaver) e dominância (Simpson) (Tabela 27). Na Mineração Calcário Xaraés, do ponto 1,38 até a base do depósito, não foram calculados os índices, pois a quantidade de fósseis não foi significativa.

Observando o índice de Shannon no depósito da Mineração Calcário Xaraés (Figura 01 ), nota-se forte queda de diversidade no ponto 3,46, assim como um grande pico em 2,18. O ponto 2,18 da Mineração, é mais diverso em número de espécies (H’) e, consequentemente, menor dominância entre as espécies.

Os depósitos menos diversos incluem o intervalo 3,46-3,96 da Mineração, e o depósito 16D. Estes micritos de menor diversidade apresentam maior dominância entre as espécies. Os demais depósitos possuem índices de diversidade que variam entre 1,20 e 1,90. 
Tabela 27 - Índices ecológicos calculados para as amostras a partir dos dados da análise de microfósseis. N-número total de indivíduos, S-número total de espécies.

\begin{tabular}{|c|c|c|c|c|c|}
\hline \multicolumn{6}{|c|}{ Índices ecológicos } \\
\hline \multicolumn{2}{|c|}{ Amostras } & $\mathrm{N}$ & $\mathrm{S}$ & Shannon $\left(\mathrm{H}^{\prime}\right)$ & Simpson (D) \\
\hline Topo & 5,16 & 31 & 5 & 1,15 & 0,40 \\
\hline \multirow{11}{*}{ 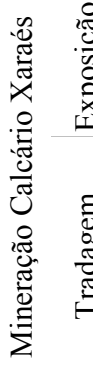 } & 4,46 & 24 & 5 & 1,04 & 0,48 \\
\hline & 3,96 & 9 & 3 & 0,68 & 0,63 \\
\hline & 3,46 & 19 & 3 & 0,54 & 0,72 \\
\hline & 2,96 & 17 & 6 & 1,59 & 0,25 \\
\hline & 2,36 & 12 & 7 & 1,75 & 0,21 \\
\hline & 2,18 & 21 & 10 & 2,12 & 0,14 \\
\hline & 2,08 & 16 & 6 & 1,42 & 0,30 \\
\hline & 1,94 & 5 & 3 & 0,95 & 0,44 \\
\hline & 1,38 & 4 & 3 & 1,04 & 0,38 \\
\hline & 1,06 & - & - & - & - \\
\hline & 0,51 & - & - & - & - \\
\hline \multirow[t]{2}{*}{ Base } & 0,01 & - & - & - & - \\
\hline & 4 & 140 & 14 & 1,90 & 0,19 \\
\hline \multirow{5}{*}{$\begin{array}{l}\frac{0}{0} \\
\frac{0}{n} \\
\stackrel{0}{0} \\
0\end{array}$} & 6 & 93 & 7 & 1,24 & 0,38 \\
\hline & 7 & 13 & 5 & 1,48 & 0,25 \\
\hline & 14 & 37 & 7 & 1,20 & 0,43 \\
\hline & $16 \mathrm{~B}$ & 21 & 8 & 1,84 & 0,19 \\
\hline & $16 \mathrm{D}$ & 5 & 2 & 0,50 & 0,68 \\
\hline
\end{tabular}

Os processos tafonômicos podem alterar os valores dos índices ecológicos. Considerando que os depósitos da Mineração Calcário Xaraés estiveram sob ação das mesmas interferências ambientais pós deposicionais, pode-se afirmar que a porção $2,18 \mathrm{~m}$ é mais diversa que as demais do perfil, assim como o intervalo 3,46-3,96 é o menos diverso. No entanto, existe a possibilidade de dissolução dos fósseis por ação da percolação de água no topo do depósito, e ação da água freática na base (Figura 109). Entre os pontos 2,96 e 2,18, haveria menor intensidade destes agentes intempéricos, a água que percola o depósito chega alcalina a estes níveis, pois já dissolveu as porções do topo, e a água freática pode não ter atingido estes níveis.

O depósito 16B, afetado por processos pedogenéticos, encontra-se entre os que possuem índice de diversidade mais homogêneo. O depósito $16 \mathrm{D}$ está exposto e não há formação de solos sobre ela, com menor diversidade, sugere-se a ação dos processos intempéricos no conteúdo fossilífero.

Os depósitos 04 e 06 provavelmente pertencem ao mesmo depósito, por sua extensão lateral. O primeiro estava sujeito a influência do rio, enquanto o segundo, só influenciado por processos pedogenéticos. Possuem índices ecológicos distintos, o depósito 04 com o número total de fósseis muito alto em relação aos demais depósitos, principalmente de ostracodes do gênero Darwinula e outros com incrustações carbonáticas (Tabela 24), estes organismos podem ser atuais, adicionados ao depósito por retrabalhamento das áreas próximas ao rio, modificando os índices ecológicos e possíveis interpretações paleoambientais. 


\section{Índice de Shannon Weaver}

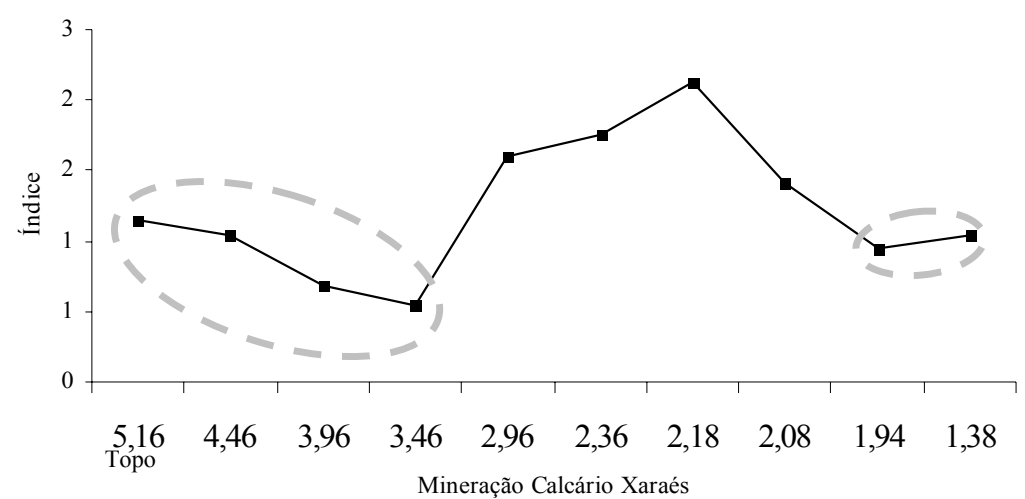

Figura 109 - Índice de Shannon Weaver calculado para os fósseis da Mineração Calcário Xaraés. Elipses indicam áreas de possível modificação intempérica no depósito.

\subsubsection{Considerações}

São comuns nos micritos indivíduos dos gêneros Biomphalaria e Acrobis e da Família Hydrobiidae.

Bivalves são raros pela ausência de movimentação das águas, pois são organismos que dependem de correntes para realizar trocas gasosas e a chegada de alimento. Indivíduos do gênero Pomacea são mais comuns nos topos dos depósitos, onde provavelmente haveria menor volume de água, sobre estes sedimentos possivelmente ocorram indivíduos tipicamente terrestres, marcando a extinção da deposição dos micritos.

Observando a Figura 110, nota-se que apesar do grande número de moluscos no topo do depósito da Mineração, o topo se caracteriza por baixa diversidade.

A diversidade do depósito aumenta em direção à base, atingindo o máximo em 2,18, onde são encontrados ostracodes, moluscos e algas caráceas, deste ponto à base a diversidade diminui, até não haver mais fósseis no depósito.

Todos ostracodes encontrados são típicos de ambientes de água doce, principalmente águas estagnadas, como lagos e pequenos corpos de água. O gênero Cypria, que ocorre preferencialmente em áreas com vegetação, é o que mais se distribui no depósito da Mineração Calcário Xaraés. 
A maior variedade de espécies de ostracodes ocorre nos pontos 2,36 e 2,18, concordando com o aumento da diversidade (H'), com indivíduos tipicamente límnicos.

\section{Fósseis no perfil da Mineração Calcário Xaraés}

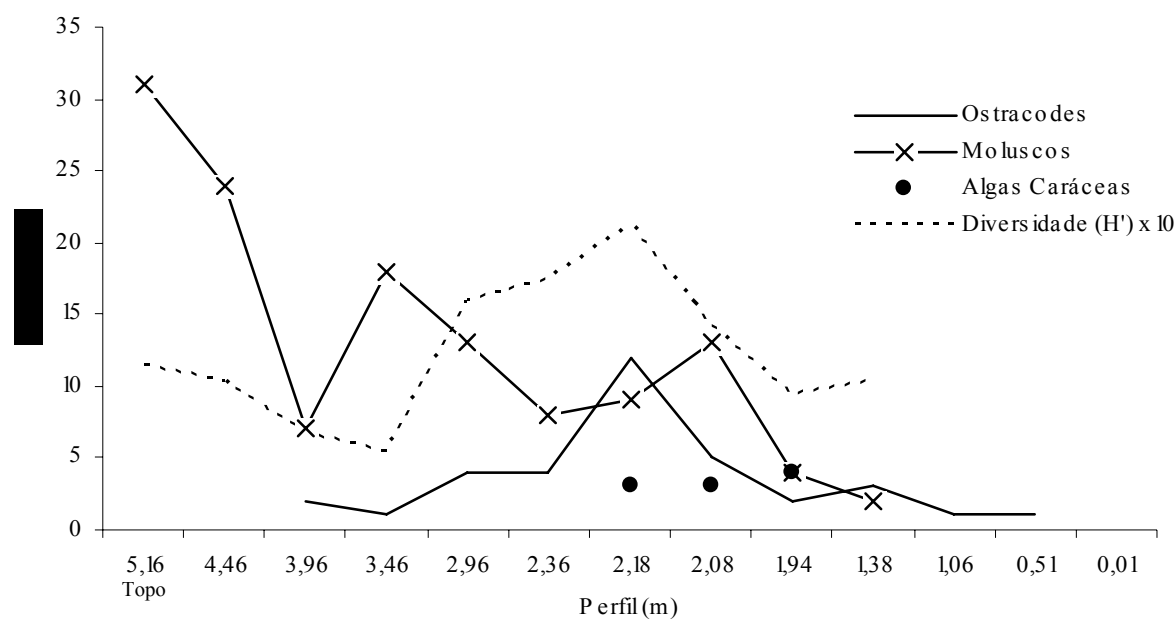
$\left(\mathrm{H}^{\prime}\right)$.

Figura 110 - Concentração de fósseis no perfil da Mineração Calcário Xaraés e o índice de diversidade

Ocorrem fragmentos de ostracodes ao longo de todo o depósito da Mineração, demonstrando a presença deles mesmo nos pontos onde não puderam ser identificadas valvas inteiras, mas provavelmente com menor concentração.

Pode-se afirmar que os girogonites ocorrem apenas nas porções 2,18 a 1,94, pois são mais resistentes a dissolução que os ostracodes, o que afastaria a hipótese de dissolução no topo e na base do depósito.

A presença de algas no intervalo 2,18 a 1,94 marca um ambiente hídrico mais estável, permitindo o desenvolvimento da vegetação, que consequentemente permitiu a maior diversidade da paleofauna.

A maior frequência de gastrópodes situa-se nas porções superiores do depósito de micritos da Mineração. Estas conchas são mais resistentes a dissolução, portanto, se estivessem presentes nas porções inferiores, em maior concentração, não teriam sido dissolvidas, já que ocorrem ostracodes nestas áreas, mais afetadas por dissolução.

Não se descarta a hipótese de dissolução dos fósseis no topo do depósito, por percolação de água, e na base, por aumento do nível freático, mas a presença de fósseis tão frágeis quanto os ostracodes, mesmo que apenas fragmentos, permite afirmar que esta dissolução não foi tão intensa. 
O depósito 04 pode conter organismos atuais, incrustados no depósito por processos de retrabalhamento, principalmente ostracodes com maior número de indivíduos, por isso apresenta alto índice de diversidade. Também ocorrem gastrópodes não encontrados nos demais micritos (Figura 111).

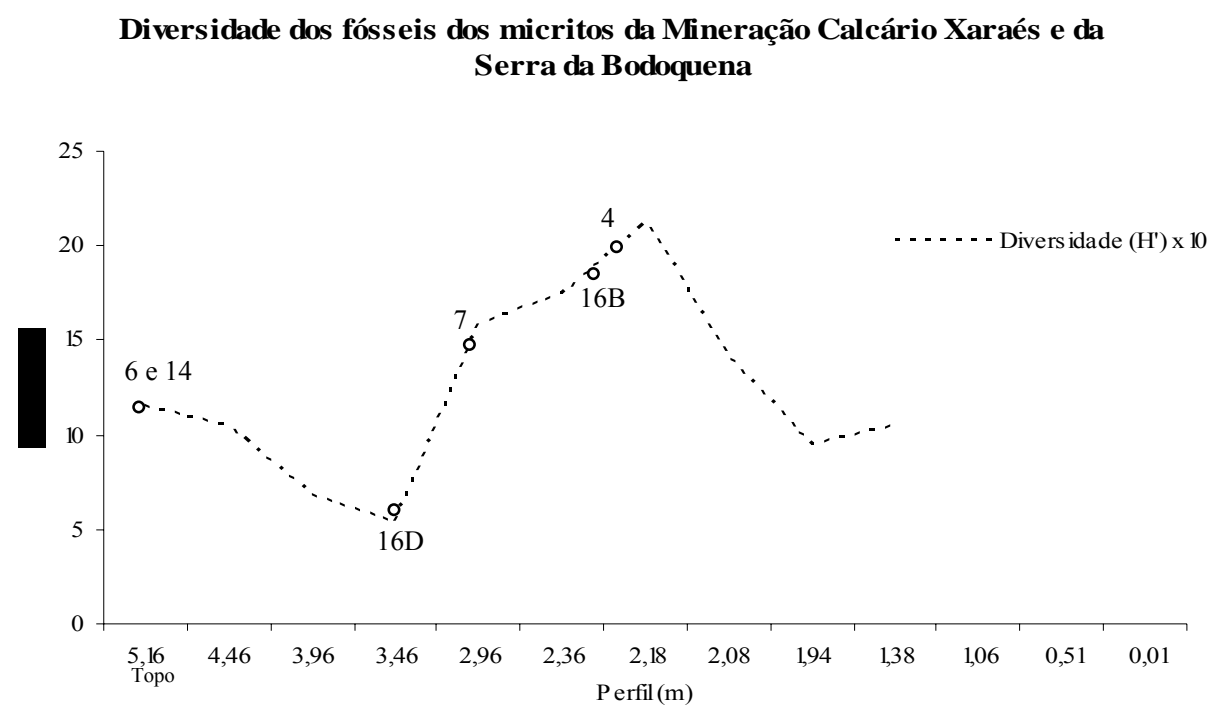

Figura 111 - Índice de diversidade dos fósseis do perfil dos micritos da Mineração Calcário Xaraés e da Serra da Bodoquena.

O depósito 04 e 06 pertencem ao mesmo afloramento de micritos, devido a sua proximidade, estando o depósito 04 sob o 06 , devido à altitude do depósito. $\mathrm{O}$ depósito 06 apresenta índice de diversidade menor que o depósito 04. Possuem, em comum, os moluscos da Família Hydrobiidae, e os gêneros Biomphalaria e Acrobis, os quais não devem ter sido transportados, pois o depósito 06 não tem influencia do rio, como o 04 . O índice de diversidade do depósito 06 assemelha-se ao do topo da Mineração Calcário Xaraés (Figura 111), onde também ocorrem poucos ostracodes.

Já o depósito 16B apresenta composição da paleofauna diferente dos micritos da Mineração, mas com similaridade do índice de diversidade com o ponto 2,36. Em ambos não ocorrem algas caráceas.

O depósito 16D, mesmo afloramento que 16B, mas intensamente intemperizado, apresenta menor índice de diversidade. Os únicos fósseis encontrados foram um girogonite de alga carácea, quatro Biomphalaria e um gastrópode não identificado, possivelmente os únicos a não serem dissolvidos. 
O depósito 07 diverge dos demais, pois apresenta grande número de girogonites, poucos gastrópodes, e a presença dos gêneros de ostracodes Cyclocypris e Cypridopsis. Possui alto índice de diversidade, mas os gastrópodes estão intensamente intemperizados, ao contrário do observado nos demais depósitos, e ainda com a presença de ostracodes bem conservados. Este depósito está em processo de dissolução, possivelmente os ostracodes e as algas caráceas sejam atuais pelo retrabalhamento dos micritos.

O depósito 14 apresenta índice de diversidade semelhante ao topo da Mineração Calcário Xaraés, possui poucos ostracodes, grande número de indivíduos da Família Hydrobiidae e a presença de um gastrópode do gênero Megalobulimulus, típico de ambientes terrestres. Este depósito marca, assim como o topo da Mineração, a evolução do depósito para um ambiente terrestre. 


\section{DISCUSSÕES}

Depósitos holocênicos com participações ponderáveis de calcários (tufas, calcretes e micritos) são frequentes na região de Bonito-MS e na Serra da Bodoquena como um todo (Oliveira, 2009). Os resultados aqui apresentados, contudo, focalizaram principalmente os micritos, em função da extensão e espessura desses depósitos ainda não encontrados em depósitos de outras regiões cársticas com desenvolvimento de tufas no Brasil.

Como a finalidade da pesquisa desenvolvida foi, principalmente, fornecer subsídios para reconstruções paleoambientais e como os micritos foram as litologias que forneceram mais informações paleontológicas, sedimentares e de isótopos $\left(\delta^{18} \mathrm{O}\right.$ e $\left.\delta^{13} \mathrm{C}\right)$, eles foram objetos preferenciais de estudo.

Os micritos são extensos e relativamente espessos em toda a região de Bonito. Contudo, a maior parte das ocorrências está intemperizada, parcialmente erodida e distribuída em áreas limitadas. Felizmente, os trabalhos de extração de micritos inconsolidados pela Mineração Calcário Xaraés, à margem do Rio Mimoso, à cerca de $19 \mathrm{~km}$ ao Sul da cidade de Bonito, forneceram uma oportunidade impar para amostrar, através de furo de trado e coletas superficiais, uma coluna de cerca de $5 \mathrm{~m}$ de micritos, onde pode ser documentada a evolução dos processos de deposição dos micritos da região, desde uma fase pré-micrito até o último processo de sedimentação, quando se atingiu a situação atual.

Os outros micritos de Bonito e da região geral de Bodoquena, foram comparados com os da frente de exploração da Mineração Calcário Xaraés. Também as ocorrências de calcários holocênicos do Pantanal e Corumbá foram visitadas.

\subsection{Os micritos da Mineração Calcário Xaraés}

Os micritos da Mineração Calcário Xaraés, obtidos em parte por coleta exposta e em parte por furo de trado, foram projetados em um perfil para estudo (Figura 110).

Comumente são encontrados na base de depósitos de tufas calcárias nódulos e oncóides, indicando maior descarga de água (Meyrick \& Preece, 2001). Na base da 
Mineração ocorrem oncólitos, parte deles possuem camadas concêntricas, indicando rolamento durante sua deposição, portanto, aumento da descarga de água.

Observando-se o esquema do perfil (Figura 112) nota-se a pequena presença de ostracodes da base até $1,94 \mathrm{~m}$ do depósito e a completa ausência de moluscos e algas caráceas. Os dados de isótopos são distintos dos demais pontos no perfil. A redução da negatividade dos valores de isótopos de oxigênio sugere neste intervalo (1) a menor intensidade dos processos evaporíticos, enquanto o aumento da negatividade dos isótopos de carbono sugere aumento quantitativo das contribuições da matéria orgânica no solo (Andrews, 2006). Isto evidencia o início dos processos deposicionais na área, e a colonização por organismos vivos.

A presença de argilominerais na base do depósito está relacionada ao aumento do volume de água, que poderia transportá-los para está área, pois a maior parte dos depósitos continentais de argilominerais é detrítica (Selley et al., 2005).

O intervalo 1,94 a 2,36m do perfil (Figura 112 2) é bem definido pela presença de uma paleofauna diversa de ostracodes e gastrópodes, e também pela presença de girogonites de algas caráceas, caracterizando uma porção com vegetação e paleofauna aquáticas.

Este intervalo (2) apresenta uma estabilização nos valores de isótopos de oxigênio e carbono, sendo um intervalo ecologicamente mais propício a colonização.

O gênero Acrobis (gastrópode), presente neste intervalo do depósito, é comum em áreas temporariamente alagadas e margens de sistemas aquáticos estáticos, mas pode ser completamente aquático (Brown et al., 1998).

A presença de girogonites de algas caráceas revela a presença de vegetação aquática, típica de lagos, principalmente alcalinos (Tappan, 1980; Feist, 2005). Ocorrem duas variedades do gênero Chara, podendo ser formas da mesma espécie, talvez por modificações morfológicas do girogonite devido a variações ambientais ou ecológicas, como altas taxas de herbivoria ou competição com outros vegetais, já que não ocorrem no mesmo nível do perfil.

Todos os gêneros de ostracodes são típicos de água doce (Van Morkhoven, 1963; Carmo et al., 2004; Krstić, 2005; Gross, 2008; Sames, 2008). Cypria é um gênero que habita áreas com bastante vegetação (Gross, 2008), ambiente confirmado pela presença de girogonites de algas caráceas. Ilyocypris pode viver em águas oligoalcalinas, enquanto Cyprideis, lagos salinos (Van Morkhoven, 1963; Krstić, 2005; Sames, 2008). Tais características ambientais podem ser explicadas pela alta concentração de carbonato nos ambientes de deposição dos micritos, ideais para a ocorrência das algas caráceas. 
A ausência de raízes, intraclastos de micritos, gretas de contração e outras estruturas sedimentares presentes em ambientes com influência de condições subaéreas, como os ambientes palustres (Alonzo-Zarza, 2003), e a presença de fósseis de ostracodes, algas caráceas e gastrópodes, caracterizam o paleoambiente gerador dos depósitos do episódio 2 da Mineração (Figura 112) como lacustre alimentado por águas subterrâneas. O local dos estudos detalhados dos depósitos da Mineração estaria longe das margens de lagos ou de rios.

A partir do ponto 2,36m do perfil da Mineração (Figura 112. 3) até o topo do depósito, os ostracodes praticamente desaparecem, representados por apenas 3 ocorrências dos gêneros Cypria, Darwinula e um indivíduo indeterminado. O gênero Darwinula habita praticamente todos os ambientes aquáticos continentais (Van Morkoven, 1963; Carmo et al., 2004; Gross, 2008), não trazendo, portanto, informações específicas sobre o paleoambiente.

Deste ponto para o topo aumentam as concentrações de gastrópodes, principalmente os macrofósseis, dominando em concentração o gênero Biomphalaria até o nível de 4,46m. Estudos com espécies atuais do gênero Biomphalaria revelam sua preferência por ambientes aquáticos pouco profundos, entre 2 e $7 \mathrm{~cm}$ de profundidade (Utzinger et al., 1997; Utzinger \& Tanner, 2000).

Segundo Tibiriçá \& Bessa (2006), estudos atuais de diversas espécies de Biomphalaria demonstraram correlação inversa entre a abundância populacional e as chuvas locais. Isto sugere que a forte presença de Biomphalaria no depósito da Mineração seria conseqüência da baixa taxa de precipitação pluviométrica no intervalo entre 2,36 e 4,46m. A presença de trona nos pontos 3,96 e 5,16 m do perfil sustentam a possibilidade de um período mais árido.

Segundo Schneck \& Fried (2005) indivíduos de Biomphalaria desenvolvem-se em condições ótimas em laboratório a $23^{\circ} \mathrm{C}$, sugerindo possível faixa de temperatura ambiental nas porções onde ocorrem indivíduos deste gênero. Outros autores sugerem condições ótimas entre 25 e $29^{\circ} \mathrm{C}$ (Loreau \& Baluku, 1987).

Estes dados corroboram as variações do isótopo de oxigênio, que após o nível de 2,36 exibem pequenas variações, sugerindo alternância entre períodos de evaporação de maior e menor intensidade.

A curva do isótopo de carbono também revela pequenas variações, demonstrando a influência da matéria orgânica do solo através de modificações ambientais ocorridas neste intervalo (Figura 112.3). 


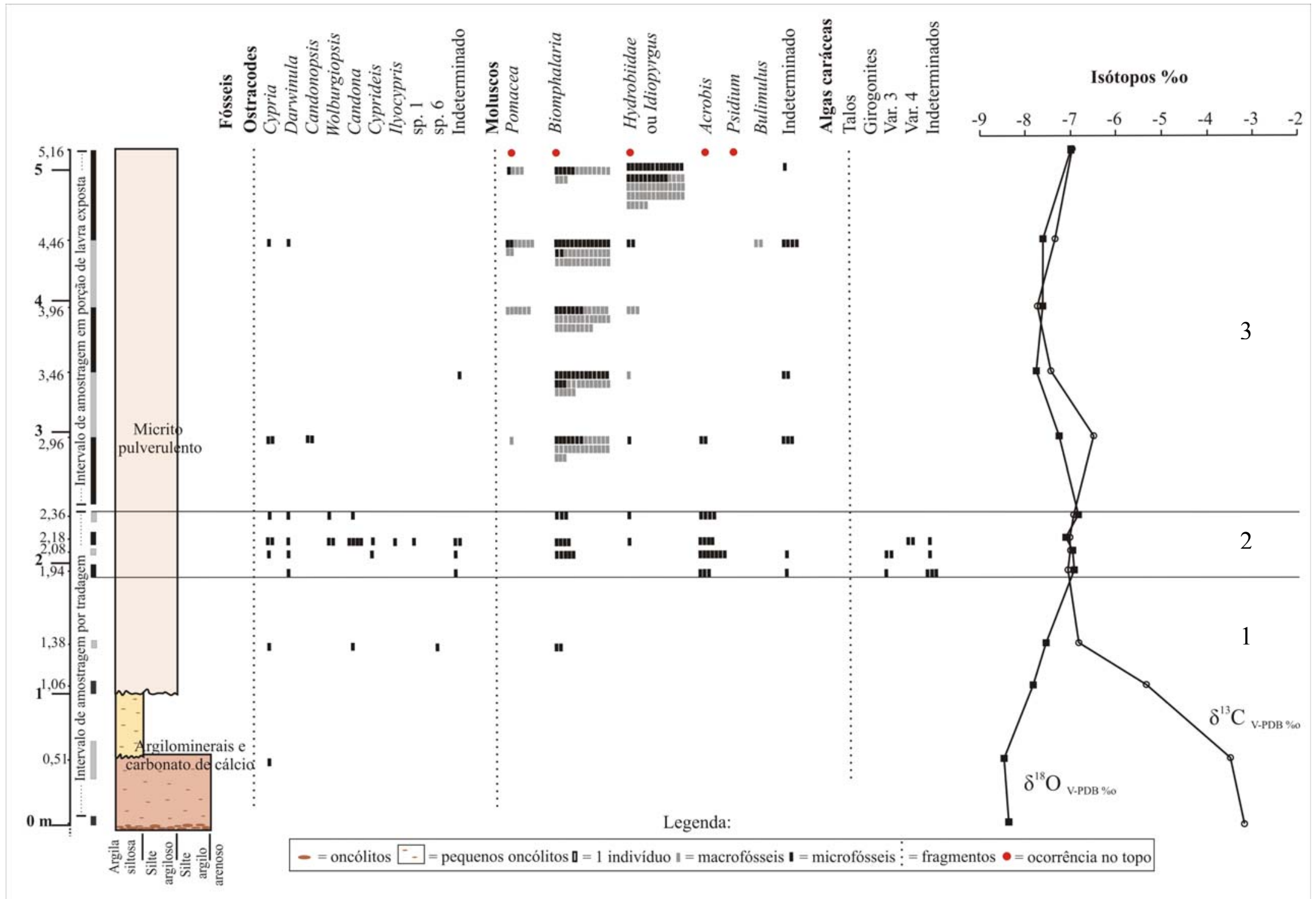

Figura 112 - Esquema dos resultados do conteúdo fossilífero, granulometria e isótopos obtidos para o depósito de micritos da Mineração Calcário Xaraés. 1, 2 e 3 referem-se aos episódios de evolução do depósito esquematizadas na Figura 113. Mais explicações no texto. 
A presença do gênero Pomacea não é elucidativa, pois é um gastrópode capaz de se adaptar a diversas condições hídricas (Mildward de Andrade, 1981 apud Pizani et al., 2005; Cowie \& Thiengo, 2003).

$\mathrm{Na}$ amostra do topo do depósito, 5,16m, há grande concentração de indivíduos da Família Hydrobiidae, principalmente do gênero Idiopyrgus (Figura 112). É um gênero sulamericano de água doce e da mesma forma que Biomphalaria habita áreas alagadas de menor volume de água (Malek, 1983). Segundo Davis (1979) Idiopyrgus também pode habitar áreas temporariamente alagadas, ter hábitos anfíbios e geralmente é encontrado junto com o gênero Biomphalaria. Na análise do bloco orientado, foram encontrados alguns indivíduos do bivalve Psidium. Segundo Meyrick \& Preece (2001) e Meyrick \& Karrow (2007) este gênero é tipicamente aquático.

O isótopo de oxigênio e de carbono do topo do depósito (Figura 112. 3) voltam a apresentar valores próximos aos observados no intervalo 2. Estes dados sugerem redução da evaporação. A presença em massa do gastrópode Idiopyrgus, marca a recolonização do ambiente.

Fragmentos de ostracodes, gastrópodes e de talos de algas caráceas aparecem em todo o perfil, em menor concentração na base. Não se descarta a hipótese de contaminação das amostras da base, mas também é possível que tenham vivido nestes pontos do depósito em pequenas concentrações, reduzindo as chances de preservação.

Apesar da ocupação da vegetação no topo do depósito de micritos da Mineração, não ficaram registrados carbonatos palustres no topo do depósito, que é um solo rico em carbonato. É provável que este processo ainda esteja em formação, devido as condições diferenciadas da região, em relação a outros depósitos palustres.

A partir dos dados obtidos, três episódios principais (1, 2 e 3 - Figura 113) refletiriam a evolução do sistema lacustre:

1. Formação da base do depósito e início da deposição dos carbonatos:

A base do depósito de micritos da Mineração Calcário Xaraés é composta por muitos oncólitos. Oncólitos se desenvolvem in situ sob condições de baixa energia durante uma 
pausa na sedimentação (Leinfelder \& Hartkopf-Fröder, 1990). Abaixo deles não foi possível realizar amostragem.

Oncólitos são produzidos em condições de pequena quantidade de água, mas a presença de alguns oncólitos envolvidos por camadas concêntricas de calcário, na base do depósito da Mineração, implica em quantidade de água suficiente para rola-los, só possível em caso de volume de água que os cubra.

Com maior elevação do nível de água, cessa-se a formação dos oncólitos e inicia-se o acúmulo de argilominerais, provavelmente transportados e precipitação de carbonato de cálcio a partir das águas ricas em bicarbonato de cálcio. Pequenos grãos revestidos por carbonato, semelhantes a oncólitos estão dispersos no sedimento, provavelmente vestígios de oncólitos retrabalhados.

Ainda neste episódio, inicia-se a sedimentação de carbonatos puros, com a persistência de alguns grãos revestidos de carbonato. Os dados da relação isotópica de oxigênio sugerem aumento do volume de água neste episódio e os de carbono, aumento da contribuição de matéria orgânica do solo.

2. Deposição de carbonatos puros, estabilidade ambiental e desenvolvimento de vegetação e comunidade animal:

Neste episódio há estabilização do volume de água, como sugerem os dados isotópicos, e deposição de carbonato de cálcio puro, o que proporcionou alta transparência da água, e colonização por ostracodes, gastrópodes e algas caráceas. A alta concentração de organismos demonstra a estabilidade do sistema, permitindo a ocupação da área.

3. Alternância dos processos evaporíticos e recarga de água, modificação da fauna:

Neste último episódio ainda há deposição de carbonatos puros, no entanto, ocorre alternância entre o processo de evaporação e a recarga de água, demonstrada pela variação 


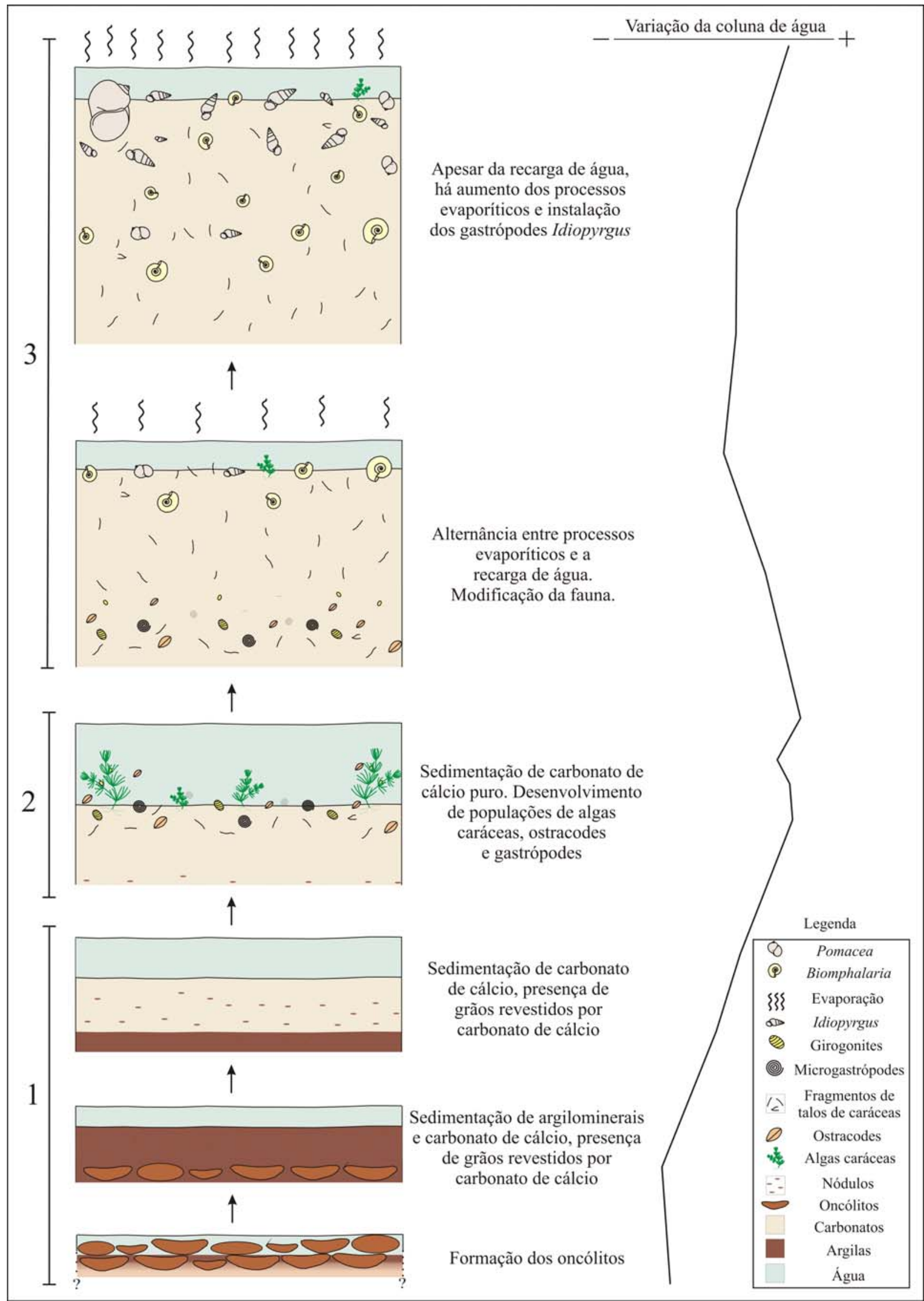

Figura 113 - Hipótese de evolução do depósito da Mineração Calcário Xaraés. O volume da coluna de água é baseado na curva obtida através dos dados de isótopos de oxigênio. Explicação no texto. 
ocorre com os dados isotópicos, além da presença de trona nos pontos 3,96 e em 5,16m, indicando períodos de aridez.

A colonização por ostracodes é extinta, assim como o gastrópode do gênero Acrobis e algas caráceas. Gastrópodes do gênero Biomphalaria em maior abundância neste episódio, sugerem pequeno volume na coluna de água, corroborando os dados isotópicos.

O último evento deste episódio é reconhecido pela redução da população de Biomphalaria e aumento da frequência da população de Idiopyrgus, que pode ocupar áreas mais secas que Biomphalaria, e teria sido causado pela diminuição do volume de água. A curva isotópica de oxigênio sugere redução da evaporação. A presença de trona e a redução da negatividade do isótopo de carbono, sugerem novamente uma fase de maior evaporação, o que provavelmente tornou as condições mais propícias a Idiopyrgus.

A partir destes episódios evolutivos do sistema lacustre hipotetizado, as análises tafonômicas do topo dos micritos da Mineração Calcário Xaraés sugerem algumas características sobre o fím da deposição de sedimentos lacustres.

Após o último evento do episódio 3 observado na Figura 113 (3) deve ter ocorrido a redução do volume de água do depósito (Figura 114 a.1), seguido pela evaporação total da água e ocupação por vegetação terrestre (a.2), e por último a ocupação de vegetação mais densa e formação de solos sobre o depósito, como visto atualmente (a.3) (Figura 114 a.4).

Os dados tafonômicos obtido da amostra orientada do topo do depósito (Figura 114) mostrou empacotamento fraco a disperso com bioclastos em posição oblíqua sem direção preferencial (Figura 114 b), demonstrando a ausência de eventos que produzissem acúmulo e orientação de bioclastos.

A maior parte dos bioclastos mostrou-se com a textura pouco alterada, mas em grande parte esbranquiçadas ou com algumas marcas de coloração, e baixa frequência de conchas fragmentadas com pequena porcentagem de área da concha afetada. Os bioclastos alterados, menos de 20\%, exibem predominantemente corrosão (Figura 114 c).

Os bioclastos esbranquiçados e a corrosão sugerem exposição da interface águasedimento, ou ainda percolação de água e modificação dos bioclastos após a deposição, sem fragmentação, que, quando ocorre, é baixa. Estas características aliadas a textura não alterada sugerem um ambiente de baixa energia. 


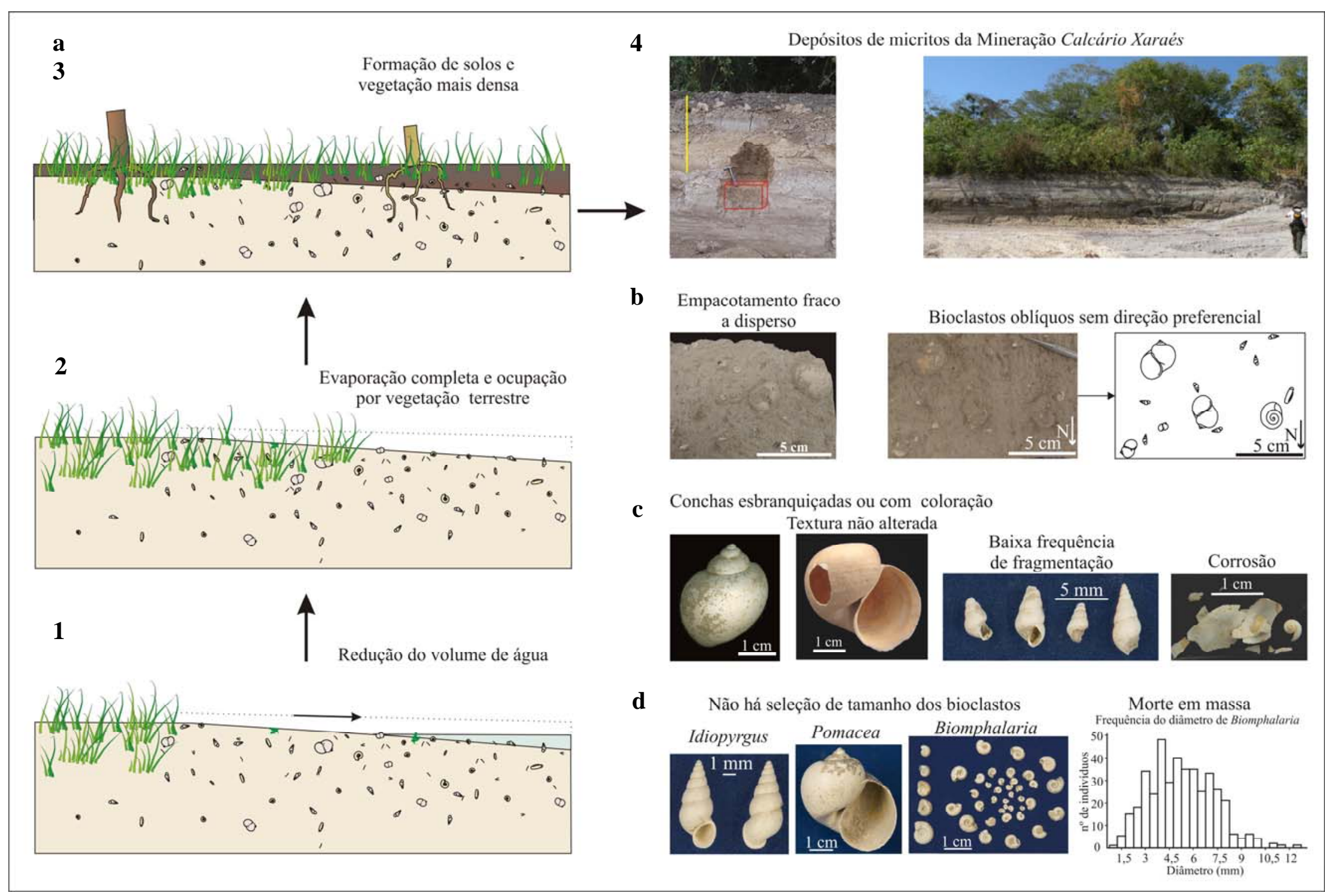

Figura 114 - Hipótese de sedimentação final do depósito de micritos da Mineração Calcário Xaraés a partir de análise do bloco orientado do topo do depósito. a) 1, 2 e 3 Hipótese dos processos finais de sedimentação do lago. 4) Depósito da Mineração Calcário Xaraés, a imagem a esquerda mostra em vermelho uma projeção do bloco estudado ainda não extraído, e em amarelo a camada de solo descartada. À direita vista geral de uma das frentes de extração de carbonatos. Mais explicações no texto. b) Feições sedimentológicas. c) Feições bioestratinômicas. d) Feições paleoecológicas. 
A paleofauna de gastrópodes dos gêneros Idiopyrgus, Pomacea e Biomphalaria se dispõe sem seleção por tamanho das conchas, sugerindo a ausência de correntes. A frequência, por tamanho, dos indivíduos de Biomphalaria reflete a população original. Comparada a estudos atuais (Utzinger et al. 1997; Utzinger \& Tanner, 2000) (Figura 114 d), possivelmente a associação reflete mortalidade em massa.

Os processos de sedimentação dos micritos da Mineração Calcário Xaraés, foram calmos, sem grandes perturbações sin ou pós-deposicionais, como estruturas de fluxos, deslizes, etc. Outras evidências de paleoambientes de baixa energia são a falta de seleção dos sedimentos e dos fósseis e bioclastos não fragmentados. As mudanças mais importantes foram as causadas por ressecamento que encerraram os processos de sedimentação, como mortalidade da população de Biomphalaria e sua substituição por Idiopyrgus.

Os dados de elementos maiores, menores e traço diferenciam apenas os pontos referentes a base do depósito de micritos composta por argilominerais. Eles mostram um agrupamento das porções referentes a micritos que compõem o perfil da Mineração Calcário Xaraés sem correlações com os dados paleontológicos e isotópicos obtidos, demonstrando a homogeneidade dos micritos quanto a estes dados.

As tufas calcárias fósseis e atuais estudadas por Oliveira (2009), também na Serra da Bodoquena, apresentam valores semelhantes aos dos micritos da Mineração Calcário Xaraés no que tange a composição química e de elementos maiores, menores e traço.

Como observado em campo, os micritos aparentam sofrer dissolução pela água dos rios atuais, principalmente no período chuvoso, que reduz o $\mathrm{pH}$ das águas dos rios. As maiores variações do isótopo de carbono sugerem modificação dos ambientes de deposição, mas com o mesmo conteúdo carbonático.

As diferenças dos dados isotópicos dos micritos da Mineração Calcário Xaraés com os resultados observados em outros calcários holocênicos da região poderiam ser explicadas pelas diferenças paleoambientais onde os calcários foram gerados. A contribuição das águas meteóricas para as águas do lago onde se depositaram os micritos da Mineração seria pequena, comparada com a água que viria do lençol freático, ou as águas das duas fontes seriam homogeneizadas no lago. O intemperismo que prevaleceu durante a formação de outros calcários da região, teria alterado a composição isotópica destes calcários. Esta hipótese ainda deverá ser testada. 
7.2. Outros depósitos de micritos da Serra da Bodoquena

A maior parte dos micritos da Serra da Bodoquena está intemperizada por exposição, pedogênese e dissolução pela água dos rios. O depósito da Mineração Calcário Xaraés é o que apresenta melhor preservação e a lavra possibilita boa visualização.

Os depósitos 04 e 06, próximos ao Rio Mimoso, pertencem a mesma área de micritos próxima as Cachoeiras do Mimoso, provavelmente formados dentro de um único sistema de deposição, mas em situações distintas de intemperismo. O depósito 04 recebe diretamente as águas do Rio Mimoso nas épocas de cheia, retrabalhando e dissolvendo seus sedimentos. Sobre o depósito 06 há crescimento de vegetação, que é removida pelas pessoas para abrir caminhos, atuando sobre ele também a exposição ao tempo.

Tanto no depósito 04, como no depósito 06, são abundantes os gastrópodes Biomphalaria, Acrobis e da Família Hydrobiidae, e o bivalve Psidium, assim como três variedades morfológicas de girogonites do gênero Chara (Figura 115).

Outros gastrópodes e dois bivalves também ocorrem nestes depósitos, assim como diversos ostracodes no depósito 04, principalmente Darwinula (Figura 115). É provável que estes organismos tenham sido transportados para estas áreas ou tenham vivido próximo a estes micritos. Sua preservação é diferente da observada na Mineração Calcário Xaraés, a maior parte está com as duas valvas, sem fragmentação, algumas muito incrustadas impedindo a identificação, é possível que tenham sido incorporadas ao depósito por retrabalhamento de sedimento atual. A ausência de ostracodes no depósito 06 pode ser reflexo da dissolução das carapaças por percolação de água.

Os valores de isótopos de carbono e oxigênio são próximos aos dos micritos da Mineração Calcário Xaraés, fase 2 (Figura 112 e 115), da mesma forma a presença de Biomphalaria e indivíduos da Família Hydrobiidae. Os gêneros Acrobis e Psidium aparecem junto com estes gastrópodes, diferindo das outras fases das ocorrências da Mineração (Figura 112,113 e 115).

O depósito 06 encontra-se em uma área com grande declividade, e o depósito 04 está sob a influência fluvial, assim sugere-se que tenham sido formados por retrabalhamento de outros depósitos, provavelmente em represamentos de água nestas áreas, mesmo com a declividade. A granulometria destes depósitos é mais grossa, de silte areno-argiloso a silte arenoso, e menor concentração de carbonatos que os da Mineração, sugerindo transporte dos 
grãos. Os argilominerais também devem ter origem alóctone. É provável que estes depósitos tenham sido áreas de alagamento do Rio Mimoso, o que se coadunaria com as evidências de transportes dos fósseis, grãos e argilas.

A análise dos dados de elementos maiores, menores e traço, para os depósitos 04 e 06, mostram estes dois depósitos com forte relação pela proximidade dos valores, já que pertencem a mesma área.

O depósito 07 (Figura 115), intemperizado pelo Rio Seputa, apresenta poucos ostracodes, apenas fragmentos de gastrópodes e grande concentração de girogonites da mesma morfologia. Seus valores de isótopos são menos negativos, bem distintos de todos os demais depósitos de micritos. A relação isotópica de oxigênio sugere menor ação evaporítica do sistema. Segundo Leng et al. (2005) a fotossíntese por algas do gênero Chara em épocas de altas temperaturas e disponibilidade de água enriquecem em ${ }^{13} \mathrm{C}$ o carbono inorgânico dissolvido, possivelmente sendo o caso deste afloramento, que exibe grande concentração de girogonites de algas do gênero Chara e valores menos negativos para $\delta^{13} \mathrm{C}_{\text {V-PDB\%o }}$ e $\delta^{18} \mathrm{O}_{\mathrm{V}}$ PDB\%o. Entretanto, é possível haver maior influência de águas subterrâneas, pois as que permanecem mais tempo no aqüífero, apresentam valores de $\delta^{13} \mathrm{C}$ V-PDB\%o menos negativos (Andrews, 2006). É um carbonato muito permeável, que pode ter propiciado a remoção de certos elementos e a dissolução de outros fósseis. Apresenta exclusivamente calcita em sua composição. É um depósito de silte muito bem selecionado e homogêneo, podendo ser a acumulação final de outros sistemas deposicionais.

O depósito 14 é um carbonato de granulometria silte argiloso (Figura 115), com 4 gêneros de ostracodes, mas em pequena concentração, gastrópodes da Família Hydrobiidae e Acrobis. A relação isotópica de oxigênio permanece dentro da faixa observada para os demais, no entanto, a de carbono é mais negativa, sugerindo maior interferência do carbono provenientes da matéria orgânica do solo (Andrews, 2006). Em campo pode-se observar, neste depósito, gastrópodes do gênero Megalobulimulus, típicos de ambientes terrestres, possivelmente explicando a relação isotópica de carbono.

Os depósito 16B e 16D pertencem ao mesmo afloramento de micritos, mas com graus de intemperismo diferentes. 16B com intenso processo pedogenético, com crescimento de vegetação e erosão, enquanto em 16D, exposto, a água da chuva, houve dissolução e posterior precipitação dos carbonatos nos poros, produzindo um depósito compacto e consolidado. 


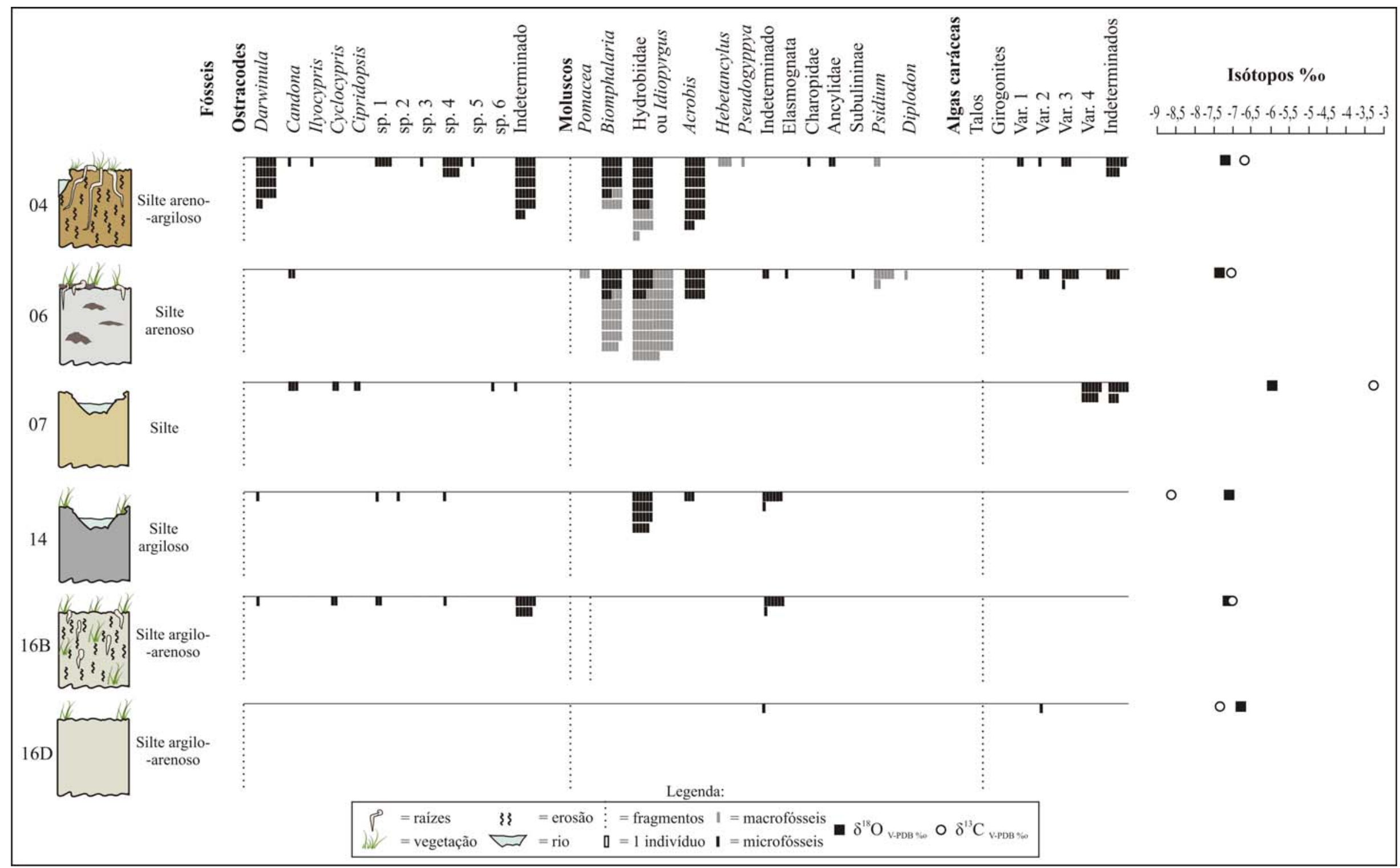

Figura 115 - Esquema dos resultados do conteúdo fossilífero, granulometria e isótopos obtidos para os depósitos de micritos da Serra da Bodoquena. Explicações 
Em 16B são encontrados ostracodes e alguns gastrópodes, mas nenhum girogonite de carácea (Figura 115). Também apresenta muita matéria orgânica atual. Em 16D são encontrados apenas poucos fragmentos de ostracodes e gastrópodes, e um girogonite de algas carácea (Figura 115).

As relações isotópicas de oxigênio e carbono possuem valores que se dispõem nas mesmas faixas que a do episódio 2 da Mineração, com poucas variações. As ações intempéricas não modificaram significantemente estes valores, apenas causaram dissoluções dos fósseis. A análise de agrupamento e a multivariada mostram semelhanças entre os dados químicos destes depósitos e os da Mineração Calcário Xaraés.

A observação dos depósitos de micritos na região permite afirmar que o intemperismo, principalmente pela água, endurece os sedimentos inconsolidados, dissolvendo parte do carbonato, que precipita nos poros do próprio sedimento. Isto pode ser observado nos depósitos da Mineração Calcário Xaraés, no leito do Rio Sucuri, na Antiga Mineração de carbonatos e no Rio Formozinho. Após o endurecimento dos micritos parece haver nova dissolução deixando-os friáveis, como observado no depósito 7 e 11 .

\subsection{As tufas da Serra da Bodoquena e os depósitos do Pantanal e Corumbá}

As Lentes do Pantanal do Miranda possuem idades semelhantes aos depósitos de tufas da Serra da Bodoquena, incluindo os micritos. Contêm gastrópodes dos gêneros Pomacea e Marisa, de hábitos semelhantes e taxonomicamente relacionados.

Pomacea é encontrada nos micritos da Serra da Bodoquena, em grande quantidade no topo dos depósitos, e em grandes extensões geográficas. Marcam o final de deposição de carbonatos no sistema lacustre da Bodoquena.

É provável que haja correlação entre as Lentes do Pantanal e os depósitos de micritos da Serra da Bodoquena, pelos gêneros de gastrópodes encontrados e idades aproximadas.

Os carbonatos da Formação Xaraiés em Corumbá, de acordo com Almeida (1945), apresentam moluscos fragmentados, como observado no depósito 34. Segundo Oliveira (2008) e Oliveira et al. (2008a) os calcretes, mais antigos, formariam a base dos depósitos de tufas na Serra da Bodoquena. Estes dados sugerem que a Formação Xaraiés se estende desde 
a Serra da Bodoquena, atravessando o Pantanal, pela sua presença em forma de Lentes, devido a erosão, atingindo Corumbá.

Segundo Ledru (1993), baseada em dados palinológicos da região central do Brasil, entre 8.500 e 5.500 anos A.P. houve aumento das temperaturas, também registradas em outros países do continente sulamericano. Estes dados concordam com a presença da deposição antiga de carbonatos na região, possivelmente em torno das idades mencionadas.

As tufas calcárias da Serra das Araras, com idades que variam de 600 a 100 mil anos A.P. a ativas (Corrêa \& Auler, 2006), são também incluídas na Formação Xaraiés (Almeida, 1945). Correlações entre os depósitos da Serra da Bodoquena, Pantanal e Corumbá são possíveis (Oliveira et al., 2008b), mas necessitam de maiores dados para corroborar correlações.

7.4. Idade dos depósitos de micritos da Serra da Bodoquena e as implicações ambientais

Datações de rochas e fósseis holocênicos da Serra da Bodoquena realizadas por diversos autores revelaram idades bem recentes (Tabela 28). Observando as idades obtidas para os micritos da Mineração (Tabela 28), sem precisão exata de correlação com o perfil aqui estudado, entre o topo, amostra de concha a $0,30 \mathrm{~m}$ de profundidade, e a amostra de concha a $3 \mathrm{~m}$ de profundidade, chegou-se a cerca de 3.600 anos de intervalo entre elas, o que equivale a cerca de 7,5 cm por 100 anos de deposição de carbonatos, pouco mais que os 4 a $7 \mathrm{~cm}$ a cada 100 anos calculado por Davies \& Griffiths (2005) para tufas de Hampshire na Inglaterra, e menos que os 14,4-16,5 cm para cada 100 anos calculados na França (Limondin-Lozouet \& Preece, 2004).

Os micritos possuem idades mais antigas que os depósitos de tufas fitohermais, 6.530 a 6.310 anos A.P. para profundidades de 3m da Mineração Calcário Xaraés próximas aos 6.469 a 5.467 anos A.P. da deposição da argila orgânica do topo do depósito do Rio Salobra (Sallun-Filho et al., 2009). As tufas fitohermais, semelhantes as atualmente formadas, possuem entre 1.986 e 3.835 anos A.P. (Sallun-Filho et al., 2009).

A idade obtida para o depósito de carbonatos da Lente do Pantanal do Miranda, 3.910 \pm 110 anos A.P. pelo método carbono 14 (Boggiani et al., 2002), apesar de não estar calibrada, é mais antiga que as conchas em micritos do topo da Mineração Calcário Xaraés, 
2.850 a 2.720 anos A.P., e mais nova que as idades obtidas para $3 \mathrm{~m}$ de profundidade, 6.530 a 6.310 anos A.P. (Sallun-Filho et al., 2009), sugerindo sua formação no mesmo intervalo de tempo que a formação dos micritos da Mineração.

Apesar destas observações, segundo Geyh et al. (1977) a datação por ${ }^{14} \mathrm{C}$ é distorcida em cerca de 1.700 anos, pois em materiais recentes, formados em água doce a concentração de ${ }^{14} \mathrm{C}$ pode ser $15 \%$ inferior ao do gás carbônico atmosférico durante sua formação. $\mathrm{Na}$ tentativa de corrigir este problema, Sallun-Filho et al. (2009) calibraram as idades com INTCAL04 Radiocarbon Age Calibration (Reimer et al., 2004), desenvolvido para calibrações em amostra do Hemisfério Norte. Segundo McCormac et al. (2004) pesquisas desenvolvendo calibrações para o Hemisfério Sul, baseadas em dados dendrocronológicos, mostraram variações em relação ao Hemisfério Norte, sendo necessária uma calibração específica para cada um dos hemisférios.

Tabela 28 - Datações obtidas pelo método ${ }^{14} \mathrm{C}$ para diversos tipos de tufa da Serra da Bodoquena. Idade calibrada com INTCAL04 Radiocarbon Age Calibration (2004) por Sallun-Filho et al. (2009). 1 - Sallun-Filho et al. (2009); 2 - Turq et al. (1987); 3 - Boggiani et al., (2002). Modificado de Sallun-Filho et al. (2009).

\begin{tabular}{|c|c|c|c|c|}
\hline \multicolumn{5}{|c|}{ Datações obtidas pelo método ${ }^{14} \mathrm{C}$ para diversos tipos de tufa da Serra da Bodoquena } \\
\hline Material & $\begin{array}{c}\text { Idade }{ }^{14} \mathrm{C} \text { anos } \\
\text { A. P. }\end{array}$ & $\begin{array}{c}\text { Idade calibrada } \\
\text { anos A.P. }\end{array}$ & $\begin{array}{l}\text { Profundidade } \\
\text { (m) }\end{array}$ & Depósito \\
\hline Concha & $2.630 \pm 60$ & 2.850 a 2.720 & 0,30 & \\
\hline Concha & $5.650 \pm 50$ & 6.530 a 6.310 & 3 & Micritos do \\
\hline Micrito & $4.200 \pm 40$ & $\begin{array}{l}4.840 \text { a } 4.780 \\
4.780 \text { a } 4.600\end{array}$ & 3 & Mineração Calcário Xaraés -1 \\
\hline Carbonato & $650 \pm 40$ & 670 a 550 & 1 & Rio Perdido - 1 \\
\hline Argila orgânica & $2.150(+500-470)$ & 3.345 a 1169 & 1,8 & \multirow{2}{*}{ Rio Salobra -2} \\
\hline Concha & $5.200(+240-230)$ & 6.469 a 5.467 & 2,1 & \\
\hline Carbonato & $3.910 \pm 110$ & - & - & Lentes do Pantanal - 3 \\
\hline \multirow{3}{*}{ Tufa fitohermal } & $2.130 \pm 60$ & $2.313 \pm 1.986$ & - & \multirow{3}{*}{ Rio Aquidabãn - 3} \\
\hline & $2.420 \pm 70$ & $\begin{array}{l}2.623 \text { a } 2.343 \\
2.713 \text { a } 2.628\end{array}$ & - & \\
\hline & $3.410 \pm 70$ & 3835 a 3.479 & - & \\
\hline
\end{tabular}

As datações por U/Th para carbonatos da Serra da Bodoquena mostraram-se ineficientes, por tratar-se de um sistema aberto (Roque, 1999; Ribeiro et al. 2001). Já os calcretes da Formação Xaraiés em Corumbá, são perfeitamente datados pelo método U/Th, resultando em uma idade pleistocênica (Roque, 1999; Ribeiro et al. 2001), não concordando 
com as idades holocênicas obtidas para os demais carbonatos, mesmo distorcidos de cerca de 1.700 anos, ficam restritos ao Holoceno.

Isto não significa que os micritos e as tufas calcárias iniciaram sua deposição apenas no Holoceno e que não correspondem à Formação Xaraiés, mas que apenas os depósitos estudados foram formados durante o Holoceno, como continuação das rochas da Formação Xaraiés.

Segundo Oliveira (2009), os calcretes da Serra da Bodoquena contêm intraclastos com fragmentos de ostracodes, sugerindo a calcretização de micritos, caracterizando a região por alternância entre fases úmidas a semi-áridas, situação que ainda permaneceu durante a deposição dos micritos da Mineração, mas de forma menos intensa.

Segundo Sallun-Filho (2005) datações em estalagmites da Serra da Bodoquena e sua relação com o volume de água dentro das cavernas, revelam níveis de água mais baixos entre 23.000 e 5.300 A.P., indicando climas mais secos, mas não áridos. A partir de 5.300 anos A.P., precipitações de crostas carbonáticas em ambientes subaquáticos, indicam níveis de água mais altos, e a estabilização de um clima mais úmido, semelhante ao atual. Tal modificação pode não ter causado o fim da deposição dos micritos, mas a formação mais evidente de tufas fitohermais, pelo aumento de fluxo de água nos rios, como visto atualmente.

Como observado em campo, os micritos mais novos são erodidos pelos rios, principalmente nas épocas chuvosas. É possível que a erosão dos micritos forneça carbonatos para a formação das tufas fitohermais, as mais antigas provavelmente participariam do mesmo processo, como pode ser deduzido pelos depósitos 03 e 11, onde ocorrem tufas formadas em quedas de água já extintas.

A presença dos carbonatos quaternários nestes depósitos sugere que houve um período mais quente e menos úmido que o atual na região, corroborado por dados palinológicos de lagos do município de Jacadigo (MS) que permitiu a individualização dos lagos entre 10.200 e 5.190 anos A.P. (Bezerra, 1999 apud Assine, 2003), possivelmente sugerindo período aproximado do início das deposições de carbonato na região.

Bertaux et al. (2002) estudaram geoquimicamente espeleotemas da caverna João Arruda em Bonito, dataram interrupções na sedimentação das estalagmites sugerindo clima mais seco entre 3.800 e 2.500 anos A.P., idade aproximada do fóssil datado para o topo da Mineração Calcário Xaraés, 2.850 a 2.720 anos A.P. (Sallun-Filho et al., 2009), sugerindo fim das deposições influenciadas pelo clima regional mais seco. 
A deposição das tufas fitohermais indica um período úmido e quente, iniciado a cerca de 2.700 anos A.P., (Sallun-Filho et al., 2009), possivelmente causando a redução dos depósitos de micritos.

Estas interpretações ainda são definitivas pela pequena quantidade de datações e o método utilizado. Novos estudos deverão ser realizados para embasar estas e futuras interpretações a respeito dos carbonatos quaternários da região da Serra da Bodoquena. 


\section{CONCLUSÕES}

Os micritos da Mineração Calcário Xaraés foram formados em um sistema lacustre, provavelmente alimentado por águas freáticas, ricas em bicarbonatos, pela dissolução dos calcários pré-cambrianos da região. Através do estudo paleontológico aliado a dados físicos e químicos pode-se determinar três episódios principais de evolução do depósito.

O primeiro episódio referente a base do perfil de micritos da Mineração Calcário Xaraés é caracterizado por um nível com oncólitos, muitos com crescimento de camadas concêntricas, indicando rolamento durante sua formação, portanto, aumento do volume de água, que cessaria a formação dos oncólitos. Houve então a sedimentação de argilominerais, provavelmente transportados, com pequenas concentrações de carbonatos, precipitados de águas freáticas ricas em bicarbonato que afloravam na área. Os argilominerais não são mais encontrados, aparecendo somente os carbonatos, indicando redução do aporte de água.

Com a estabilização do nível da água, passa-se ao segundo episódio de evolução do depósito, um nível com fósseis de ostracodes, gastrópodes e algas caráceas, que colonizaram a área em uma fase mais estável das condições ambientais.

No terceiro episódio houve variação entre aumento e redução dos processos evaporíticos, marcado pela ausência de ostracodes e algas caráceas, e predomínio do gastrópode Biomphalaria, que pode indicar pequena altura na coluna de água e temperaturas em torno de $25^{\circ} \mathrm{C}$. No topo do depósito ocorre redução da concentração de indivíduos do gênero Biomphalaria, e aumento da população de Idiopyrgus, sugerindo nova modificação das condições ambientais.

O término da deposição dos sedimentos do lago foi causado pela evaporação de todo volume de água do lago, seguido por ocupação da área por vegetação terrestre, atingindo portes como os vistos atualmente na área da Mineração Calcário Xaraés.

A análise tafonômica indicou características sobre o fim das condições propícias para a formação do depósito, como ausência de eventos que produzissem acúmulo e orientação de bioclastos, que ficaram expostos na interface água-sedimento antes do soterramento em ambiente de baixa energia, indicando que a sedimentação dos micritos da Mineração Calcário Xaraés, foram calmos, sem grandes perturbações sin ou pós-deposicionais.

Outros depósitos de micritos estudados também apresentam os fósseis de ostracodes, algas caráceas e gastrópodes. A comparação com os demais depósitos de micritos da região 
demonstrou a forte presença de indivíduos do gênero Biomphalaria e da Família Hydrobiidae colonizando os topos desses depósitos, o gênero Pomacea também é facilmente reconhecido em campo, por apresentar maior tamanho, além de ser frequêntemente encontrado sob formas viventes sobre os depósitos em geral, contribuindo para a proposta de idade recente dos depósitos. Depósitos com maior presença de grãos e bioclastos diversos podem representar planícies de alagamentos e represamentos.

Diferente de outros depósitos de tufas da Europa (Žak et al, 2001; Limondin-Lozouet \& Preece, 2004; Davies \& Griffiths, 2005 e Meyrich \& Karrow, 2007), os micritos da Serra da Bodoquena praticamente não contêm espécies de moluscos de hábitos terrestres, marcando início e término da deposição dos carbonatos sem interrupção do abastecimento de água.

Micritos consolidados são encontrados na região provavelmente originados por intemperismo causado pela água, como observado na Mineração Calcário Xaraés, na Antiga Mineração de carbonatos no centro do município de Bonito e no leito do Rio Sucuri.

O Rio Sucuri erode e expõe micritos consolidados, possivelmente pertencentes ao mesmo depósito dos micritos da Mineração Calcário Xaraés e os que foram lavrados onde hoje existe o empreendimento turístico "Praia da Figueira". Devido a proximidade destes pontos e apresentarem elevação de terreno aproximadas (Figura 48), é possível afirmar que compõem um único depósito de micritos, evidenciando uma grande área alagada durante a formação destes depósitos.

As coletas de campo mostram que os depósitos de tufas calcárias na região, fósseis e atuais, com preservação de animais e vegetais, possuem extensão muito maior que as já registradas, e provavelmente tem extensões ainda maiores, expondo-se principalmente próximos aos leitos dos rios atuais. Os micritos dissolvidos pelos rios, juntamente com os calcários do Grupo Corumbá, são fonte de carbonatos para as tufas de cachoeiras atuais.

Os depósitos de tufas calcárias da Serra da Bodoquena, principalmente micríticos, podem ter sido formados dentro do Holoceno e aqueles relacionados aos sistemas freáticos ainda encontram-se em processo de deposição.

A formação destes lagos indica um período de aumento no volume de água, seguido por aumento das temperaturas, marcando condições ambientais mais amplas, já que este tipo de depósito estende-se por uma grande área.

Estes depósitos de micritos são possivelmente mais novos que os calcretes descritos por Almeida (1945) da Formação Xaraiés, com menores valores de datações, sendo 
depositados por processos contínuos após a formação de calcretes, visto que, existe a possibilidade de um processo sazonal, entre quente e úmido e quente e seco, que produziria os micritos alternadamente aos calcretes, sendo os micritos fontes carbonáticas para os calcretes, como ocorre com as tufas formadas nos rios atuais, afetando também a região do Pantanal e Corumbá, marcados pela presença de carbonatos. Estes tipos de rochas podem representar importantes marcadores climáticos principalmente para os últimos 5.000 anos A.P., sendo que os últimos 2.700 na região podem ser caracterizados por aumento da umidade, fim da deposição dos depósitos micríticos e instalação dos depósitos de tufas de cachoeiras e barragens. 


\section{REFERÊNCIAS BIBLIOGRÁFICAS}

ALMEIDA, F. F. M. 1945. Geologia do Sudoeste Mato-grossense. Min. Agricultura, Div. Geol. Miner./DNPM. Rio de Janeiro. Boletim 116: 118 p.

ALMEIDA, F. F. M. 1964. Geologia do Centro-Oeste Mato-grossense. Min. Minas e Energia, Div. Geol. Miner./DNPM. Rio de Janeiro. Boletim 215: 96 p.

ALMEIDA, F. F. M. 1965. Geologia da Serra da Bodoquena. Min. Agricultura, Div. Geol. Miner./DNPM. Rio de Janeiro, Boletim 219: 96p.

ALONSO-ZARZA, A. M. 2003. Palaeoenvironmental significance of palustrine carbonates and calcretes in the geological record. Earth-Science Reviews. 60:261-298.

ANDREWS, J. E. 2006. Palaeoclimatic records from stable isotopes in riverine tufas: Synthesis and review. Earth-Science Reviews. 75:85-104.

ANTHONY, J. W., BIDEAUX, R. A., BLADH, K. W. \& NICHOLS, M. C. 2001-2005. Handbook of Mineralogy. Mineral Data Publishing. Disponível em: $<$ www.handbookofmineralogy.org > . Acesso em: 10/10/2007.

ARAÚJO, H. J. T.; SANTOS NETO, A.; TRINDADE, C. A. H.; PINTO, J. C. A.; MONTALVÃO, R. M. G. DE; DOURADO, T.D. de C.; PALMEIRA, R.C. de B.; TASSINARI, C.C.G. 1982 Geologia. In: Projeto Radambrasil. Folha SF-21 Levantamento de Recursos Naturais, 28. Campo Grande. Rio de Janeiro, MME. p. 9 -124.

ARAÚJO, J. F. V.; LIMA, M. I. C. DE; BEZERRA, P. E. L.; KAUL, P. F. T.; COELHO, F. A. DE J. DA F.; GONZALEZ, S. R. \& ROCHA, R. M. (Coordenadores). 1999. Glossário Geológico. IBGE. Rio de Janeiro. 214 p.

ASSINE, M. L. 2003. Sedimentação na Bacia do Pantanal mato-grossense, Centro-Oeste do Brasil. Tese de livre-docência. Instituto de Geociências e Ciências Exatas. UNESP. Rio Claro. 106f.

BERTAUX, J., SONDAG, F., SANTOS, R., SOUBIÈS, F., CAUSSE, C., PLAGNES, V., LE CORNEC, F., SEIDEL, A.. 2002. Paleoclimatic record of speleothems in a tropical region: study of laminated sequences from a Holocene stalagmite in central-west Brazil. Quaternary International 89, 3-16.

BEZERRA, M. A. O., 1999. O Uso de Multi-traçadores na Reconstrução do Holoceno no Pantanal Mato-grossense, Corumbá, MS. Tese de Doutorado. Universidade Federal de São Carlos, São Carlos, 214 f.

BOGGIANI, P. C. \& COIMBRA, A. M. 1995. Quaternary limestones of the Pantanal área, Brasil. Anais da Academia Brasileira de Ciências. 67: 343-349.

BOGGIANI, P. C.; COIMBRA, A. M.; GESICKI, A. L.; SIAL, A. N.; FERREIRA, V. P.; RIBEIRO, F. B.; FLEXOR, J.M. 2002. Tufas Calcárias da Serra da Bodoquena, MS - 
Cachoeiras petrificadas ao longo dos rios. In: Schobbenhaus, C.; Campos, D. A.; Queiroz, E. T.; Winge, M.; Berbert-Born, M. L. C. (Edits.). Sítios Geológicos e Paleontológicos do Brasil. 1. ed. Brasília: DNPM/CPRM - Comissão Brasileira de Sítios Geológicos e Paleobiológicos (SIGEP), 2002, v.01: 249-259.

BOGGIANI, P. C.; COIMBRA, A. M.; RIBEIRO, F. B.; FLEXOR, J.M.; SIAL, A. N. \& FERREIRA, V. P. 1998. Significado paleoclimático das lentes calcárias do Pantanal do Miranda - Mato Grosso do Sul. In: XL CONGRESSO BRASILEIRO DE GEOLOGIA. Anais. Belo Horizonte. pg 88.

BOGGIANI, P. C.; FAIRCHILD, T. R. \& COIMBRA, A. C. 1993. O Grupo Corumbá (Neoproterozóico-Cambriano) na região central da Serra da Bodoquena (Faixa Paraguai), Mato Grosso do Sul. Revista Brasileira de Geociências, 23(3): 301-305.

BROWN, K. M.; ALEXANDER, J. E. \& THROP, J. H. 1998. Differences in the ecology and distribution of lotic pulmonate and prosobranch gastropods. American Malacological Bulletin 14(2):91-101.

CABRAL, M. C., COLIN, J. P. \& AZEREDO, A. C. 2008. Taxonomy and palaeoecology of new brackish ostracod species from the Middle Cenomanian of Lousa, Lisbon region, Portugal. Palaeogeography, Palaeoclimatology, Palaeoecology. 264:250-262

CARMO, D.A., 1998, Taxonomia, paleoecologia e distribuição estratigráfica dos ostracodes da Formação Alagamar (Cretáceo Inferior), Bacia Potiguar, Brasil. Tese de Doutorado, UFRGS, 156p.

CARMO, D. A. DO; TOMASSI, H. Z. \& OLIVEIRA, S. B. S. G. DE. 2004. Taxonomia e distribuição estratigráfica dos ostracodes da Formação Quiricó, Grupo Areado (Cretáceo Inferior), Bacia Sanfranciscana, Brasil. Revista Brasileira de Paleontologia. 7(2):139149.

CLARKSON, E. N. K. 1993. Invertebrate palaeontology and evolution. $3^{\text {a }}$ edition. Chapman \& Hall. 434 p.

CORREAA, D. \& AULER, A. S. 2006. Caracterização, cronologia e gênese das tufas da Serra das Araras, Mato Grosso. I SIMPÓSIO DE GEOTECNOLOGIAS NO PANTANAL. Anais. Campo Grande-MS: Embrapa Informática Agropecuária/INPE. p.165-174.

CORRÊA, D. \& AULER, A. S. 2007. Caracterização, cronologia e gênese das tufas da Serra das Araras, Mato Grosso. ENCONTRO BRASILEIRO DE ESTUDOS DO CARSTE. Carste 2007. Anais. São Paulo-SP. Redespeleo Brasil. p. 11.

COWIE, R. H. \& THIENGO, S. C. 2003. The Apple snails of the Americas (Mollusca: Gastropoda: Ampullariidae: Asolene, Felipponea, Marisa, Pomacea, Pomella): A nomenclatural and type catalog. Malacologia. 45(1):41-100.

CRISTALLI, P. S. 2006 Macrofitofósseis em Tufos Calcários Quaternários do Norte da Bahia como Indicadores Paleoclimáticos. Tese de doutorado. Instituto de Geociências USP, São Paulo. 195 f. 
DAVIES, P. \& GRIFFITHS, H. I. 2005. Molluscan and ostracod biostratigraphy of Holocene tufa in the Test valley at Bossington, Hampshire, UK. The Holocene. 15(1):97110.

DAVIS, G. M. 1979. The origin and evolution of the gastropod Family Pomatiopsidae, with emphasis on the Mekong River Triculinae. Allen Press. 120p.

ERMAN, S.; PHILLIPS, F. M. \& MCPHERSON, B. J. O. L. 2005. The role of "excess" $\mathrm{CO} 2$ in the formation of trona deposits. Applied Geochemistry. 20: 2217-2232.

ESTEBENET, A. L. 1998. Allometric growth and insight on sexual dimorphism in Pomacea canaliculata (gastropoda: Ampullariidae). Malacologia. 39(1-2): 207-213.

EUGSTER, H. P. 1980. Geochemistry of evaporitic lacustrine deposits. Annual Review of Earth and Planetary Sciences. 8:35-63.

FEIST, M. (Coord.) 2005. Treatise on Invertebrate Paleontology. Part B. Protoctista 1. V.1 Charophyta. Geo. Soc. Am. and Univ. Kansas. 170p.

FORD, T. D.; PEDLEY, H. M. 1996. A review of tufa and travertine deposits of the world. Earth-Science Reviews. 41: 117-175.

FRENZEL, P.; HENKEL, D.; SICCHA, M. \& TSCHENDEL, L. 2005. Do ostracod associations reflect macrophyte communities? A case study from the brackish water of the southern Baltic Sea coast. Aquatic Science. 67:142-155.

GESICKI, A. L. D. \& RICCOMINI, C. 1998. Neotectônica na borda sudeste do Pantanal sulmatogrossense. Congresso Brasileiro de Geologia, Anais: Belo Horizonte. Brasil. p.84.

GEYH, M. A.; BENZER, J, H.; RHODESCHMAN, G. 1977. Problem of dating Pleistocene and Holocene soils by radiometric methods. In.: D. H. Yaalon (ed.) Paleopedology: origin, nature and dating of paleosoils. Jerusalem, International Soc. Soil Science and Israel University Press, 63-75.

GHILARDI, R. P. 2004. Tafonomia comparada e paleoecologia dos macroinvertebrados (ênfase em Trilobites), da Formação Ponta Grossa (Devoniano, Sub-bacia Apucarana), Estado do Paraná, Brasil. Tese de doutoramento. Instituto de Geociências. USP. $113 \mathrm{f}$.

GIANNINI, P. C. F.; SINFRONIO, E. A. S.; MELO, M. S.; FACHINI, M.; VICTORINO, M. 2004. Manual de procedimentos analíticos. Laboratório de Sedimentologia. Instituto de Geociências USP.

GOMES, C. S. F. 1988. Argilas: o que são e para que servem. Lisboa: C Gulbenkian. 457 p.

GOBBO-RODRIGUES, S. R. 2002. Carófitas e ostracodes do Grupo Bauru, Cretáceo Superior Continental do Sudeste do Brasil. Dissertação de Mestrado. UNESP: Rio Claro. 137f. 
GREKOFF, N. 1970. Aperçu sur lês Ostracodes Fossiles. Publications de L'institut Français du Pétrole. Société dês Editions Technip. Paris. 103 p.

GRIM, R. E. 1968. Clay mineralogy. McGraw-Hill: New York. 596p.

GROSS, M. 2008. A limnic ostracod fauna from the surroundings of the Central Paratethys (Late Middle Miocene/Early Late Miocene; Styrian Basin; Austria). Palaeogeography, Palaeoclimatology, Palaeoecology. 264:263-276.

GUERRA, A. T. 1993. Dicionário geológico-geomorfológico. $8^{a}$ ed. Rio de Janeiro. 446p.

HAIR, J. F. JR.; ANDERSON, R. E.; TATHAM, R. L. \& BLACK, W. C. 2005. Análise multivariada de dados. Bookman, Porto Alegre. 593p.

HOLZ, M.; SIMÕES, M. G. 2002. Elementos fundamentais de Tafonomia. UFRGS, Porto Alegre $231 \mathrm{p}$.

IMET - Instituto Nacional de Meteorologia. Climatologia. Gráficos climatológicos. Disponível em: <http://www.inmet.gov.br/html/clima.php> Acesso em: 22/08/2007.

JACKSON, M. L. \& SHERMAN, G. D. 1963. Chemical weathering of minerals in soils. Advances in Agronomy. 5:219-318.

KEITH, M. L.; ANDERSON, G. M. \& EICHLER, R. 1964. Carbon and oxygen isotopic composition of mollusk shells from marine and fresh-water environments. Geochimica et Cosmochimica Acta. 28:1757-1786.

KNIGHT, J. B.; COX, L. R.; KEEN, A. M.; SMITH, A. .; BATTEN, R. L.; YOCHELSON, E. L.; LUDBROOK, E. L. ROBERTSON, R. \& YONGE, C. M. 1960. Mollusca 1, Part I In: R. C. Moore \& C. W. Pitrat (ed). Treatise on invertebrate paleontology. University of Kansas Press and Geological Society of America. 1351 p.

KOTZIAN, C. B. \& SIMÕES, M. G. 2006. Tafonomy of recent freshwater Molluscan death assemblages, Touro Passo Stream, Southern Brazil. Revista Brasileira de Paleontolologia. 9(2): 243-260.

KRSTIĆ, N., SAVIĆ, L. \& JOVANOVIĆ G. 2005. Ostracodes and paleolimnology on examples of Balkan Peninsula. XV INTERNATIONAL SYMPOSIUM ON OSTRACODA. Anais. Berlin. 12-15.

LEDRU, M-P. 1993. Late quaternary environmental and climatic changes in central Brazil. Quaternary research. 39:90-98.

LEINFELDER, R. R.; HARTKOPF-FRÖDER, C. 1990. In situ accretion mechanism of concavo-convex lacustrine oncoids ('swallow nests') from the Oligocene of the Mainz Basin, Rhineland, FRG. Sedimentology, 37(2): 287-301.

LIMONDIN-LOZOUET, N. \& PREECE, R. C. 2004. Molluscan successions from the Holocene tufa of St Germain-le-Vasson, Normandy (France) and their biogeographical significance. Journal of Quaternary Science. 19(1) 55-71. 
LOREAU, M. \& BALUKU, B. 1987. Growth and demography of populations of Biomphalaria pfeifferi (Gastropoda, Planorbidae) in the laboratory. Journal of Molluscan Studies. 53:171-177.

LUCAS, Y.; LUIZÃO, F. J.; CHAUVEL, A.; ROUILLER, J. \& NAHON, D. 1993. The Relation Between Biological Activity of the Rain Forest and Mineral Composition of Soils. Science. 260(23):521-523.

MALEK, E. A. 1983. The South American hydrobioid genus Idiopyrgus Pilsbry, 1911. The Nautilus. 97(1) 16-20.

MANLY, J. F. JR. 1994. Multivariate statistical methods. A primer. Chapman \& Hall, London. 215p.

MARDIA, K. V. 1972. Statistics of directional data. Academic Press. 357p.

MCCORMAC, F. G.; HOGG, A. G.; BLACKWELL, P. G.; BUCK, C. E.; HIGHAM, T. F. G. \& REIMER, P. J. 2004. SHCAL04 southern hemisphere calibration, 0-11.0 cal kyr bp. Radiocarbon. 46(3):1087-1092.

MCCREA, J.M. 1950. On the Isotopic Chemistry of Carbonates and a Paleotemperature Scale. Journal of Chemical Physics. 18(6):849-857.

MEYRICK, R. A. \& KARROW, P. F. 2007. Three detailed, radiocarbon-dated, Holocene tufa and alluvial fan mollusc successions from southern Ontário: The first in northeastern North America. Palaeogeography, Palaeoclimatology, Palaeoecology. 243: 250-271.

MEYRICK, R. A. \& PREECE, R. C. 2001. Molluscan successions from two Holocene tufas near Northampton, English Midlands. Journal of Biogeography, 28, 77-93.

MINITAB 15.1.30.0 2007. Minitab Inc.

MOORE, R. C. 1954. Treatise on invertebrate paleontology. Part D. Protista 3. Geological Society of America. 195p.

MOORE, R. C. (Ed.) 1955. Treatise on invertebrate paleontology. Part E. Archaeocyatha and Porifera. Geological Society of America. 122p.

MOORE, R. C. (Ed.) 1961. Treatise on invertebrate paleontology. Part Q. Arthropoda 3. Crustacea Ostracoda. Geological Society of America. 442p.

MORI. P.E.; REEVES, S. CORREIA, C. T. \& HAUKKA, M. 1999. Development of a fused glass disc XRF facility and comparison with pressed powder pellet technique at Instituto de Geociências, São Paulo University. Revista Brasileira de Geociências. 29(3):441446.

MUSACCHIO, E. A. 1970. Ostracodos de las superfamílias Cytheracea y Darwinulacea de la Formación La Amarga (Cretacico Inferior) en la Provincia de Neuquén, Republica Argentina. Revista de la Asociación Paleontológica Argentina, 7(4):301-317. 
MUSSA, D. 2004. Paleobotânica: conceituação geral e grupos fósseis. In.: I. S. Carvalho. (ed) Paleontologia. V. 1. Editora Interciência. $2^{\mathrm{a}}$ ed. 413-508.

NAMIOTKO, T., SZCZECHURA, J., NAMIOTKO, L. 2003. Ostracoda of the Eemian Interglacial at Kruklanki in NE Poland. Studia Quarternaria 20, 3-24.

ODUM, E. P. 1988. Ecologia. Guanabara Koogan: Rio de Janeiro. 434 p.

OLIVEIRA, E. C. 2009. Tufas calcárias da Serra da Bodoquena. Dissertação de mestrado. Instituto de Geociências. USP. 147f.

OLIVEIRA, E. C.; UTIDA, G.; BOGGIANI, P. C. \& PETRI, S. 2008a. A Formação Xaraiés e as tufas calcárias da Serra da Bodoquena, MS. In: XLIV CONGRESSO BRASILEIRO DE GEOLOGIA. Anais. Curitiba-PR. p.991.

OLIVEIRA, E. C.; UTIDA, G.; BOGGIANI, P. C. \& PETRI, S. 2008b. Calcretes da Formação Xaraiés, Mato Grosso do Sul. In: XLIV CONGRESSO BRASILEIRO DE GEOLOGIA. Anais. Curitiba-PR. p.992.

PAWLOWSKY-GLAHN, V. \& EGOZCUE, J. J. 2006. Compositional data and their analysis: an introduction. In.: A., Mateu-Figueiras, G. \& PAWLOWSKY-GLAHN, V. (eds) Compositional data analysis in the geosciencies: From theory to practice. Geological Society of London. Special Publications. 264:1-10

PEDLEY, H. M. 1990. Classification and environmental models of cool freshwater tufas. Sedimentary Geology, 68:143-154.

PENTECOST, A. 1995. The Quaternary travertine deposits of Europe and Asia Minor. Quaternary Science Reviews. 14, 1005-1028.

PETRI, S. 1955. Charophyta cretácicas de São Paulo (Formação Bauru). Boletim da Sociedade Brasileira de Geologia. São Paulo. 4(1): 67-72.

PIRES-ZOTTARELLI, C. L. A. \& ROCHA, M. 2007. Novas citações de Chytridiomycota e Oomycota para o Parque Estadual das Fontes do Ipiranga (PEFI), SP, Brasil. Acta botânica brasileira 21(1):125-136.

PIZANI, N. V.; ESTEBENET, A. L. \& MARTÍN, P. R. 2005. Effects of submersion and aerial exposure on clutches and hatchings of Pomacea canaliculata (Gastropoda: Ampullariidae). American Malacological Bulletin 20:55-63.

RAVEN, P. H.; EVERT, R. F. \& EICHHORN, S. E. 2002. Biologia Vegetal. 5a ed. Editora Guanabara Koogan: Rio de Janeiro. 728p.

REIMER, P. J.; BAILLIE, M G. L.; BARD, E.; BAYLISS, A.; BECK, J. W.; BERTRAND, C. J. H.; BLACKWELL, P. G.; E BUCK, C. E.; BURR, G. S.; CUTLER, K. B.; DAMON, P. E.; EDWARDS, R. L.; FAIRBANKS, R. G.; FRIEDRICH, M.; GUILDERSON, T. P.; HOGG, A. G.; HUGHEN, K. A.; KROMER, B.; MCCORMAC, G.; MANNING, S.; RAMSEY, C. B.; REIMER, R. W.; REMMELE, S.; SOUTHON, J. R.; STUIVER, M.; TALAMO, S.; TAYLOR, F. W.; VAN DER PLICHT, J. \& 
WEYHENMEYER, C. E. 2004. INTCAL04 terrestrial radiocarbon age calibration, 0-26 cal kyr bp. Radiocarbon. 46(3): 1029-1058.

RIBEIRO, F. B.; ROQUE, A. BOGGIANI, P. C.; FLEXOR, J. M. 2001. Uranium and Thorium series desequilibrium in quaternary carbonate deposits from the Serra da Bodoquena and Pantanal do Miranda, Mato Grosso do Sul state, central Brazil. Apllied Radiation and Isotopes. 54(1): 153-173.

RICCOMINI, C. \& ASSUMPÇÃO, M. 1999. Quaternary Tectonics in Brazil. Episodes. 22(3): 221-225.

ROQUE, A. 1999. Desequilíbrio da série do Urânio e do Tório em alguns depósitos carbonáticos quaternários da Bacia do Pantanal. Tese de doutoramento. Instituto de Astronomia, Geofísica e Ciências Atmosféricas. 128 f.

RUPPERT, E. E. \& BARNES, R. D. 1996. Moluscos. Cap. 10. In.: E. E.RUPPERT \& R. D. BARNES. Zoologia dos Invertebrados. $6^{\text {a }}$ ed. Roca: São Paulo. 1029 p.

SALGADO-LABOURIAU, M. L.; CASSETI, V.; FERRAZ-VICENTINI, K. R.; MARTIM, L.; SOUBIĖS, F.; SUGUIO, K. \& TURQ, B. 1997. Late quaternary vegetacional and climatic changes in cerrado and palm swamp from central Brazil. Palaeogeography, Palaeoclimatology, Palaeoecology. 128:215-226.

SALLUN-FILHO, W. 2005. Geomorfologia e geoespeleogia do carste da Serra da Bodoquena, MS. Tese de doutorado. Instituto de Geociências - USP, São Paulo. $193 \mathrm{f}$.

SALLUN FILHO, W.; KARMANN, I.; BOGGIANI, P.C. 2004. Paisagens cársticas da Serra da Bodoquena (MS). In: Mantesso Neto, V.; Bartorelli, A.; Carneiro, C.D.R.; Brito Neves, B.B. (eds.). Geologia do continente Sul-americano: evolução da obra de Fernando Flávio Marques de Almeida. Beca, São Paulo. 423-433p.

SALLUN FILHO, W.; KARMANN, I.; SALlUN, A. E. M. \& SUGUIO, K. 2009. Quaternary tufa in the Serra da Bodoquena karst, West-central Brazil: evidence of wet period. In: International Climate Change: Global Risks, Challenges and Decisions. IOP Conf. Series: Earth and Environmental Science 6. Copenhagen. Disponível em: < http://www.iop.org/EJ/toc/1755-1315/6/7> Acesso em: 10/03/2009.

SALLUN FILHO, W.; SILVA E SILVA, L. H. \& KARMANN, I. 2007. Estromatólitos recentes do Rio Formoso, Bonito, MS. XX CONGRESSO BRASILEIRO DE PALEONTOLOGIA. Anais. Búzios-RJ. p.119.

SCHEFFLER, S. M. 2006. Levantamento Paleontológico do Projeto corredor de Biodiversidade Miranda-Serra da Bodoquena. In: M. Brambilla \& A. Pellin (Coord.). Projeto Corredor de Biodiversidade Miranda - Serra da Bodoquena: Ações Prioritárias do Plano de Conservação e Implementação. Relatório Técnico Final. Volume I. Ampliação do Conhecimento sobre a Biodiversidade e Sócio-economia. 434p.

SCHNECK, J. L. \& FRIED, B. 2005. Growth of Biomphalaria glabrata (NMRI strain) and Heliosoma trivolis (Colorado strain) under laboratory conditions. American Malacological Bulletin. 20: 71-73. 
SELlEY, R. C.; COCKS, L. R. M. \& PLIMER, I. R. 2005. Encyclopedia of Geology. Volume One. Elsevier. 594 p.

SHEPARD, F. P. 1954. Nomenclature based on sand-silt-clay ratios. Journal of Sedimentary Petrology. 24:151-158.

SIMÕES, M. G. \& GHILARDI, R. P. 2000. Protocolo tafonômico e paleoautoecológico como ferramenta nas análises paleossinecológicas de invertebrados: exemplos de aplicação em concentrações fossilíferas do Paleozóico da Bacia do Paraná, Brasil. Instituto de Geociências, UFRGS: Porto Alegre. Pesquisas em Geociências, 27(2):3-13.

SIMONE. L. R. 2006. Land and freshwater molluscs of Brazil. EGB. São Paulo. 390p.

SMITH, R. J. 1999. Possible fossil ostracod (Crustácea) eggs from the Cretaceous of Brazil. Journal of Micropalaeontology. 18:81-87.

SOARES, P. C.; ASSINE, M. L. \& RABELO, L. 1998. The Pantanal Basin: Recent tectonics, relationships to the Transbrasiliano Lineament. IX SIMPÓSIO BRASILEIRO DE SENSORIAMENTO REMOTO. Anais: Santos, Brasil. 459-469.

SUGUIO, K. 1998. Dicionário de Geologia Sedimentar e áreas afins. Bertrand Brasil: Rio de Janeiro. $1.222 \mathrm{p}$.

TAPPAN, H. 1980. Charophytes and Umbellinaceans. In: H. Tappan. 1980. The Paleobiology of Plant Protists. W. H. Freeman \& Company. San Francisco. 913-963 p.

THOMAS, J.D. \& DALDORPH, P.W. G. 1991. Evaluation of bioengineering approaches aimed at controlling pulmonate snails: The effects of light attenuation and mechanical removal of macrophytes. Journal of Applied Ecology. 28:532-546.

TIBIRIÇÁ, S. H. S. \& BESSA, E. C. A. 2006. Identificação morfológica e molecular, biometria, abundância e distribuição geográfica de Biomphalaria spp. (Preston, 1910) (Mollusca, Planorbidae) no município de Juiz de Fora, Estado de Minas Gerais. Revista Brasileira de Zoociências. 8(2): 218.

TREFETHEN, J. M. 1950. Classification of sediments. American Journal of Science. 248:55-62.

TURQ, B.; SUGUIO, K.; SOUBIÉS, F.; SERVANT, M. \& PRESSINOTI, M. N. 1987. Alguns terraços fluviais do Sudoeste e do Centro-Oeste brasileiro por radiocarbono: possíveis significados paleoclimáticos. In: I CONGRESSO DA ABEQUA, Anais: Porto Alegre (RS), Brasil. 379-392.

UREY, H. C.; EPSTEIN, S.; LOWENSTAM, H. A. \& MCKINNEY, C. R. 1951. Measurements of paleotemperatures and temperatures of the upper cretaceous of England, Denmark, and the southeastern United States. Geological Society of America Bulletin. 62(4):399-416. 
UTIDA, G.; OliveirA, E. C., PETRI, S. \& BOGGiAni, P. C. 2008. Microfósseis em micritos quaternários da Serra da Bodoquena-MS como indicadores peloambientais. In: XLIV CONGRESSO BRASILEIRO DE GEOLOGIA. Anais. Curitiba-PR. p.796.

UTIDA, G.; PETRI, S.; SALLUN FILHO, W. \& BOGGIANI, P. C. 2007. Gastrópodes em tufos calcários da Serra da Bodoquena, Bonito, MS. In: XX CONGRESSO BRASILEIRO DE PALEONTOLOGIA. Anais. Búzios-RJ. Resumos. p.146.

UTZINGER, J.; MAYOMBANA, C.; SMITH, T. \& TANNER, M. 1997. Spatial microhabitat selection by Biomphalaria pfeifferi in a small perennial river in Tanzania. Hydrobiologia 356: 53-60.

UTZINGER, J. \& TANNER, M. 2000. Microhabitat Preferences of Biomphalaria pfeifferi and Lymnaea natalensis in a Natural and a Man-made Habitat in Southeastern Tanzania. Memorial Instituto Oswaldo Cruz, Rio de Janeiro, 95(3): 287-294.

VAN MORKHOVEN, F. P. C. M. 1962. Post-Palaeozoic Ostracoda: Their morphology, taxonomy and economic use. Vol. I General. Elsevier: New York. 204 p.

VAN MORKHOVEN, F. P. C. M. 1963. Post-Palaeozoic Ostracoda: Their morphology, taxonomy and economic use. Vol. II Generic descriptions. Elsevier: New York. 478 p.

WITTE, R. S. \& WITTE, J. S. 2005. Estatística. $7^{\text {a }}$ ed. LTC. 486p.

WRIGHT, V. P. \& TUCKER, M. E. 1991. Calcretes. Oxford, Inglaterra: Blackwell Publishing. 352P.

ŽAK, K.; HLADÍKOVÁ, J.; BUZEK, F.; KADLECOVÁ, R.; LOŽEK, V.; CÍLEK, V.; KADLEC, J.; ŽIGOVÁ; BRUTHANS, J. \& ŠT’ASTNÝ, M. 2001. Holocenní vápense a krasový pramen ve Svatém Janu pod Skalou v Českém Krasu. Czech Geological Survey Special Papers. Praha. 13:135p. 
PRANCHAS 
Prancha I - Microfósseis encontrados na Mineração Calcário Xaraés, entre os pontos 5,16 e 2,96 da porção exposta do depósito.

1-5: $\quad$ ponto 5,16

1: estrutura esferoidal interpretada como possível Heliozoa

2: fragmento de carapaça de ostracode indeterminado com ornamentação pontuada

3: gastrópode da Família Pomatiopsidae, Gênero Idiopyrgus

4: gastrópode de Família e Gênero Indeterminados

5: talo de alga carácea recoberto por carbonato

6-8: $\quad$ ponto 4,46

6: gastrópode de Família e Gênero Indeterminados

7: gastrópode jovem da Família Planorbidae, Gênero Biomphalaria

8: estrutura esferoidal interpretada como possível Heliozoa

9-14: $\quad$ ponto 3,96

9 e 10: ostracode do Gênero Darwinula. 9: vista interna da valva esquerda. 10: detalhe da inserção muscular.

11 e 12: ostracode do Gênero Cypria. 11: vista interna da valva direita. 11: detalhe das inserções musculares

13: fragmento de carapaça de ostracode indeterminado com ornamentação reticulada e pontuada com poucos poros

14: estrutura esférica semelhante a ovos de ostracodes

15: $\quad$ ponto 3,46

15: gastrópode de Família e Gênero Indeterminados

16-20 ponto 2,96

16: talo de alga carácea com 24 células corticais seqüenciais, do tipo haplostiquo completo 17 e 18: ostracode do Gênero Candonopsis. 17: vista interna da valva esquerda. 18: detalhe das inserções musculares

19 e 20: ostracode do Gênero Cypria. 19: vista interna da valva direita. 20: detalhe das inserções musculares 
PRANCHA I

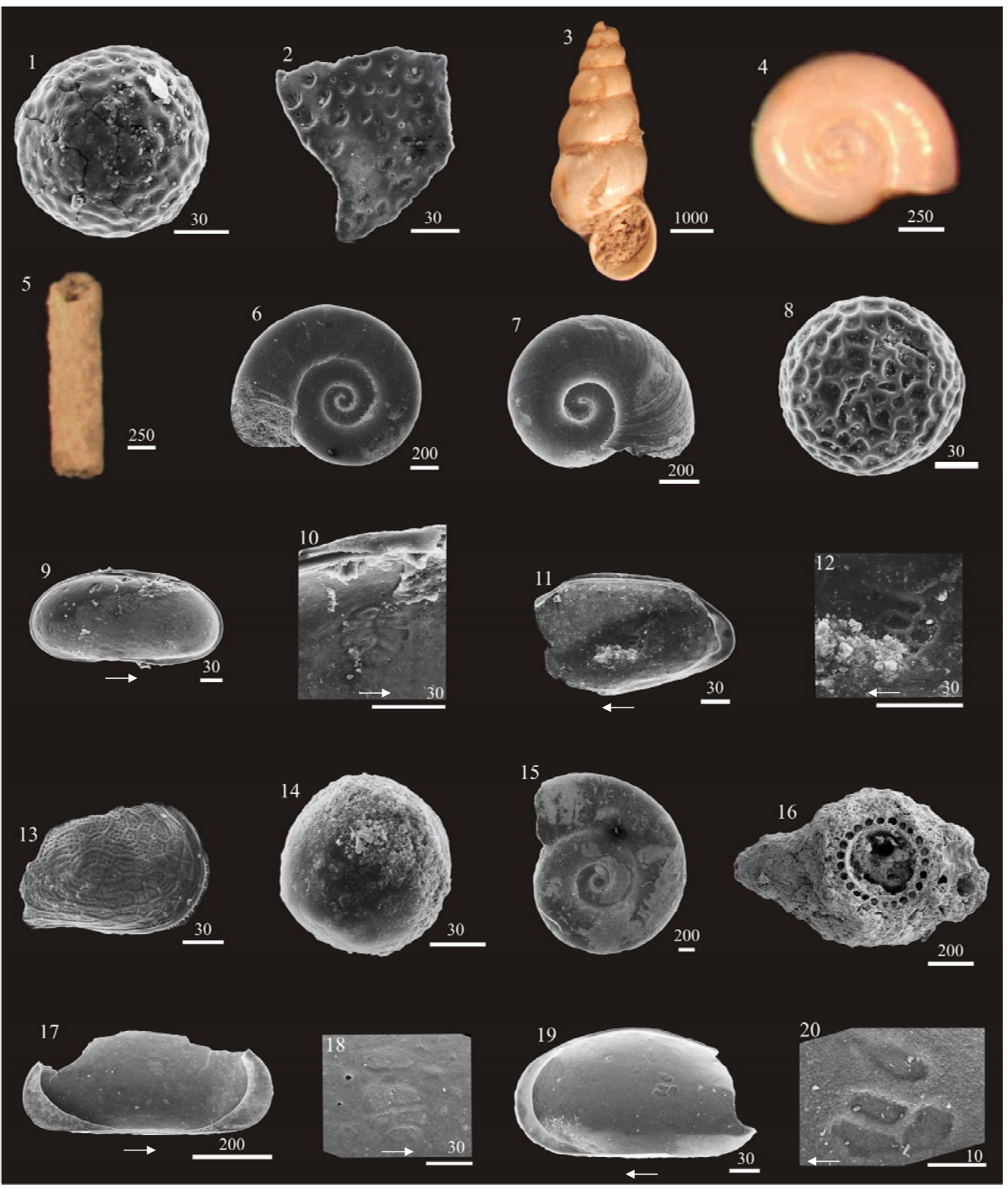


Prancha II - Microfósseis encontrados na Mineração Calcário Xaraés, entre os pontos 2,36 e 2,18 da porção obtida por tradagem do depósito.

1-11: $\quad$ ponto 2,36

1 e 2: ostracode do Gênero Darwinula. 1: vista interna da valva esquerda. 2: detalhe da inserção muscular.

3 e 4: ostracode não identificado, semelhante a Candona, quanto a morfologia externa. 3: vista interna da valva esquerda. 4: detalhe das inserções musculares

5: ostracode do Gênero Cypria. Vista interna da valva direita

6 e 7: ostracode do Gênero Candona. 6: vista interna da valva direita. 7: detalhe das inserções musculares

8: fragmento de carapaça de ostracode com ornamentação reticulada com poros em forma de papilas, semelhante a Globotalicypridea Cabral e Colin, gen. nov.

9: fragmento de carapaça de ostracode indefinido com ornamentação levemente pontuada

10 e 11: fragmento de carapaça de ostracode com reticulação formando pentágonos semelhante as de espécimes fêmeas de Candona

12-26: ponto 2,18

12: estrutura acicular, provável espícula de Porifera

13 e 14: ostracode da espécie Wolburgiopsis chinamuertensis. 13: vista interna da valva esquerda. 14: vista externa da valva direita

15 e 16: ostracode do Gênero Ilyocypris sp. 1. 15: vista lateral externa da valva esquerda. 16: vista lateral interna da valva direita.

17, 18 e 19: ostracode do Gênero Cypria. 17: vista externa da valva direita. 18: vista interna da valva esquerda. 19: detalhe das inserções musculares

20: ostracode descrito como sp.1. Vista interna da valva esquerda.

21, 22 e 23: ostracode do Gênero Candona. 21: vista externa da valva esquerda. 22: vista interna da valva esquerda. 23: detalhe das inserções musculares

24: girogonite do Gênero Chara forma 4

25: ostracode do Gênero Darwinula. Vista interna da valva esquerda

26: ostracode do Gênero Cyprideis. Vista externa da valva esquerda 
PRANCHA II

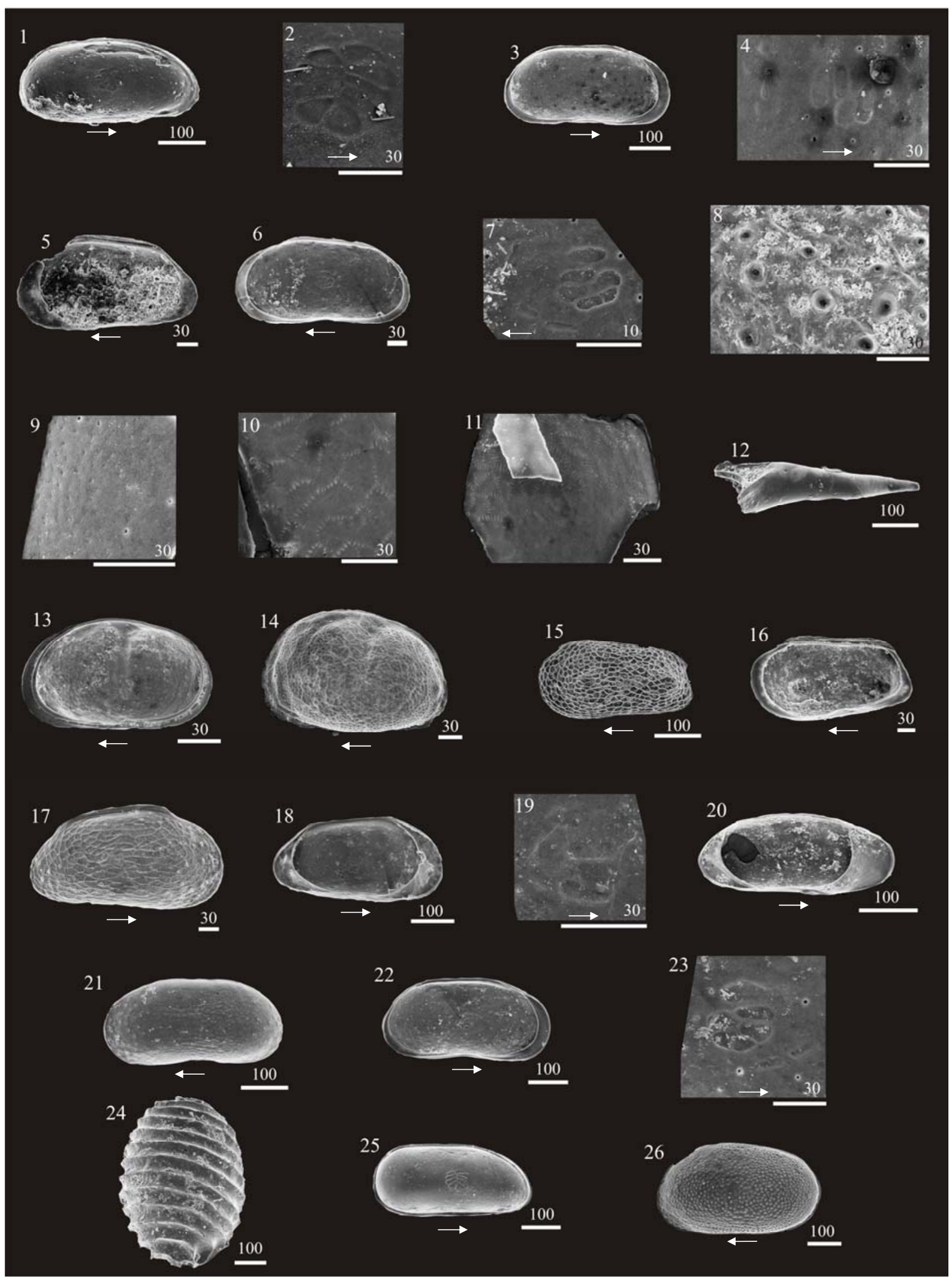


Prancha III - Microfósseis encontrados na Mineração Calcário Xaraés, entre os pontos 2,08 e 0,01 da porção obtida por tradagem do depósito.

1-9: $\quad$ ponto 2,08

1 e 2: ostracode do Gênero Cypria. 1: vista interna da valva esquerda. 2: detalhe das inserções musculares

3: ostracode do Gênero Darwinula. Vista externa da valva direita.

4: Ornamentação da carapaça do ostracode do Gênero Cyprideis

5: Girogonite do Gênero Chara, ápice.

6, 7: girogonite do Gênero Chara forma 3. 6: base. 7: vista lateral.

8 e 9: gastrópode da Família Planorbidae do Gênero Acrobis. 8: visão lateral. 9: visão do ápice

10-12: ponto 1,94

10: gastrópode de Família e Gênero Indeterminados

11: fragmento de girogonite do Gênero Chara forma 3, vista lateral.

12: ostracode do Gênero Darwinula. Vista interna da valva direita.

13-16: ponto 1,38

13 e 14: ostracode do Gênero Cypria. 13: vista interna da valva esquerda. 14: detalhe das inserções musculares

15 e 16: valva direita do ostracode Fam. et gen. Indet. 5. 15: vista interna em lupa. 16: vista interna em MEV

17-20: ponto 1,06

17: ostracode do Gênero Candona. Vista interna da valva esquerda

18: fragmento de carapaça de ostracode com ornamentação reticulada pouco marcada, semelhante à descrita para Cypria

19: estrutura esférica semelhante a ovos de ostracodes

20: grãos revestidos por poucas camadas carbonáticas

21-23: ponto 0,51

21: fragmento de carapaça de ostracode com ornamentação reticulada bem marcada semelhante à descrita para Ilyocypris

22 e 23: grãos revestidos por poucas camadas carbonáticas

24-25: ponto 0,01

24: tubos carbonáticos sem ligação com as caráceas

25: grão revestido por poucas camadas carbonáticas 
PRANCHA III
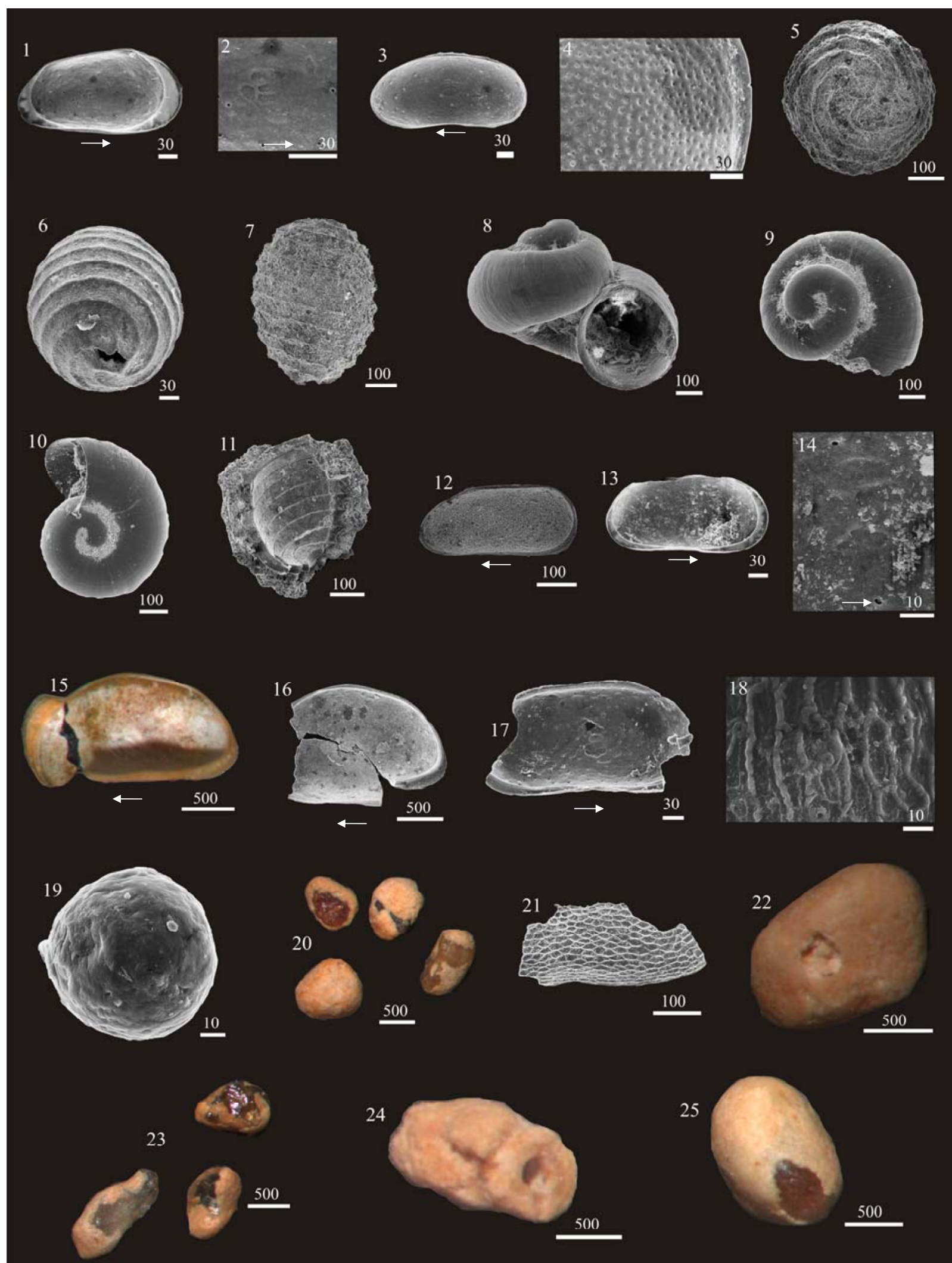
Prancha IV - Microfósseis encontrados nos depósitos 04 e 06, Cachoeiras do Mimoso.

1-15: depósito 04

1: ostracode descrito como sp.1. Vista lateral da carapaça

2: ostracode do Gênero Darwinula. Vista lateral da carapaça

3: ostracode do Gênero Ilyocypris sp. 2. Vista lateral da carapaça

4: ostracode descrito como sp.4. Vista lateral da carapaça

5: ostracode descrito como sp.3. Vista lateral da carapaça

6: estrutura esferoidal interpretada como possível Heliozoa

7: girogonite do Gênero Chara forma 1

8: girogonite do Gênero Chara forma 3

9: estruturas alongadas semelhantes aos ovos de ostracodes recentes, Darwinula stevensoni

10: ostracode do gênero Notodromas. Vista lateral da carapaça

11: gastrópode da Família Charopidae, Gênero Indeterminados

12: gastrópode da Família Hydrobiidae, Gênero Indeterminados

13: bivalve da Família Pisidiidae, Gênero Psidium

14: gastrópode da Família Ancylidae, Gênero Indeterminados

15: gastrópode da Subordem Elasmognata, Família e Gênero Indeterminados

16-23: depósito 06

16: estrutura acicular, provável espícula de Porifera

17: girogonite do Gênero Chara forma 2

18: girogonite do Gênero Chara forma1

19: girogonite do Gênero Chara forma 3

20: gastrópode de Família e Gênero Indeterminados

21: gastrópode Família e Gênero Indeterminados

22 e 23: Família Subulinidae, SubFamília Subulininae, Família e Gênero Indeterminados 
PRANCHA IV

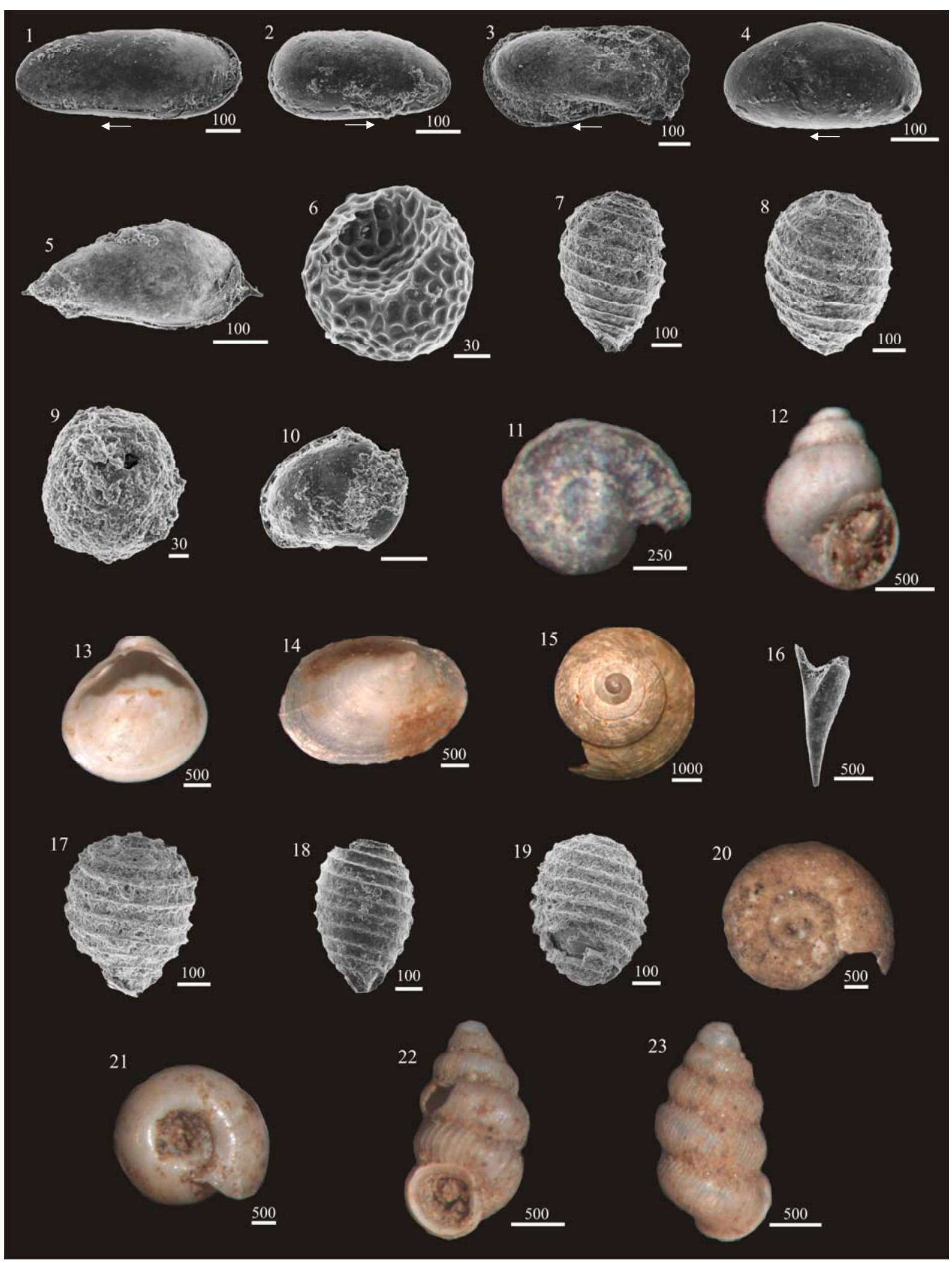


Prancha V - Microfósseis encontrados nos depósitos 07, Rio Seputa, e 14, Rio Campina.

1-12: depósito 07

1 e 2: ostracode do Gênero Cyclocypris. 1: vista interna da valva esquerda. 2: detalhe das inserções musculares

3 e 4: ostracode do Gênero Cypridopsis. 3: vista interna da valva esquerda. 4: detalhe das inserções musculares

5, 6 e 7: ostracode do Gênero Cypridopsis. 5: vista externa da valva direita. 6: vista interna da valva direita. 7: detalhe das inserções musculares

8: ostracode do Gênero Candona. Vista lateral da carapaça

9: fragmento do ostracode Fam. et gen. Indet. 5.

10, 11 e 12: girogonite do Gênero Chara forma 4, 10 e 11: vista lateral. 12: base

13-24: depósito 14

13: ostracode do Gênero Darwinula. Vista lateral da carapaça

14: ostracode descrito como sp.2. Vista dorsal da carapaça

15: ostracode descrito como sp.1. Vista lateral da carapaça

16: estruturas alongadas semelhantes aos ovos de ostracodes recentes, Darwinula stevensoni

17 a 19: estruturas esféricas interpretadas como fungos. 17: muitas esferas juntas por pedúnculo agregadas ao sedimento. 18: detalhe do pedúnculo que as une. 19: detalhe de uma das esferas.

20: gastrópode da Família Planorbidae, Gênero Acrobis

21: gastrópode da Família Hydrobiidae, Gênero indeterminado

22: gastrópode Família e Gênero Indeterminados

23 e 24: gastrópode de Família e Gênero Indeterminados. 23: ápice. 24: porção inferior 
PRANCHA V

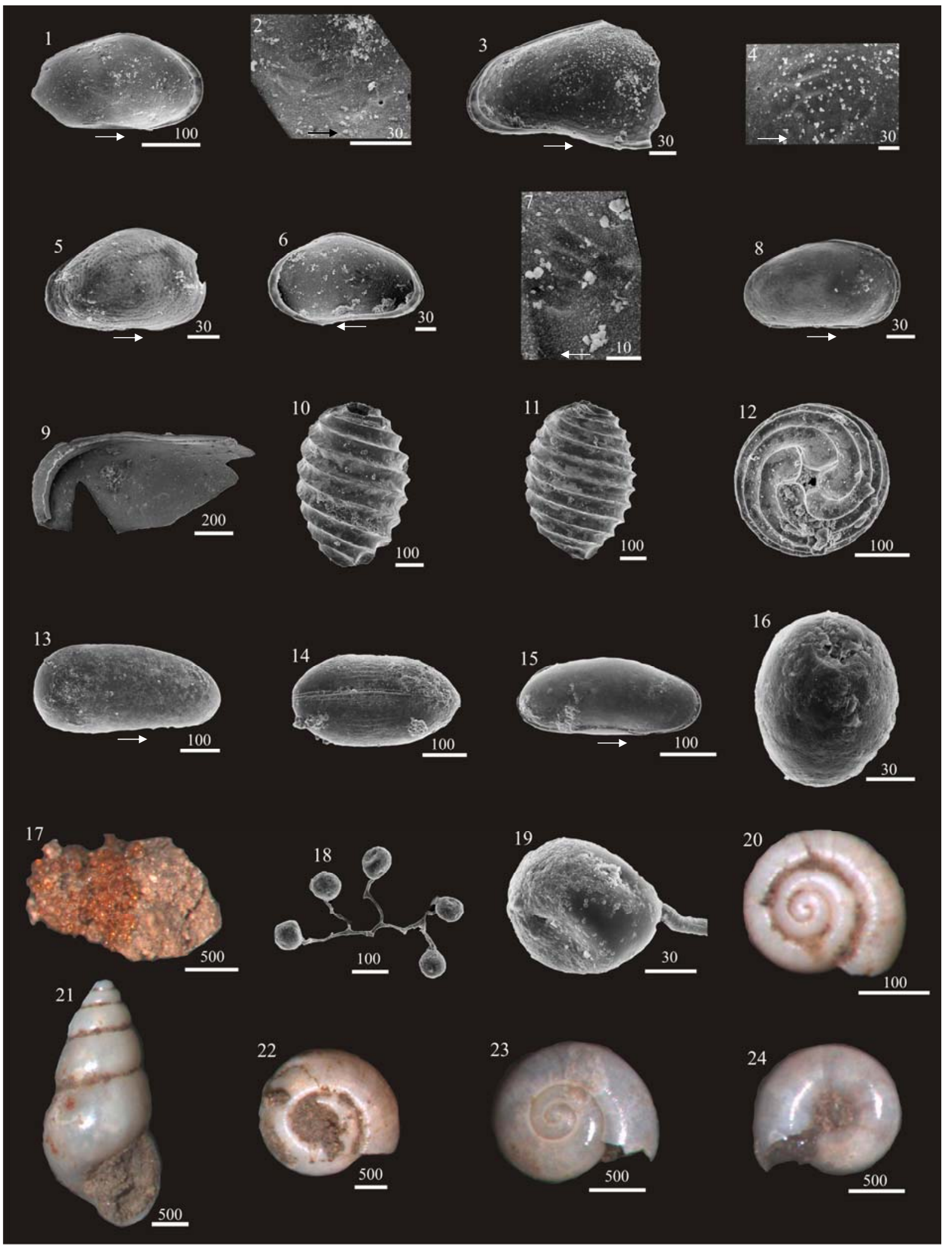


Prancha VI - Microfósseis encontrados nos depósitos 16B e 16D, Antiga Mineração de carbonatos.

1-9: $\quad$ depósito $16 \mathrm{~B}$

1: gastrópode Família e Gênero Indeterminados

2: gastrópode Família e Gênero Indeterminados

3: ostracode identificado como sp.4. Vista lateral da carapaça

4: ostracode do Gênero Darwinula. Vista lateral da carapaça

5: ostracode identificado como sp.1. Vista lateral da carapaça

6, 7 e 8: ostracode do Gênero Cyclocypris. 6: vista externa da carapaça. 7: vista interna da carapaça direita. 8: detalhe das inserções musculares

9: estrutura esferoidal interpretada como possível Heliozoa

10-12: depósito 16D

10: girogonite do Gênero Chara forma 2

11: gastrópode de Família e Gênero Indeterminados

12: gastrópode da Família Planorbidae, Gênero Biomphalaria 


\section{PRANCHA VI}

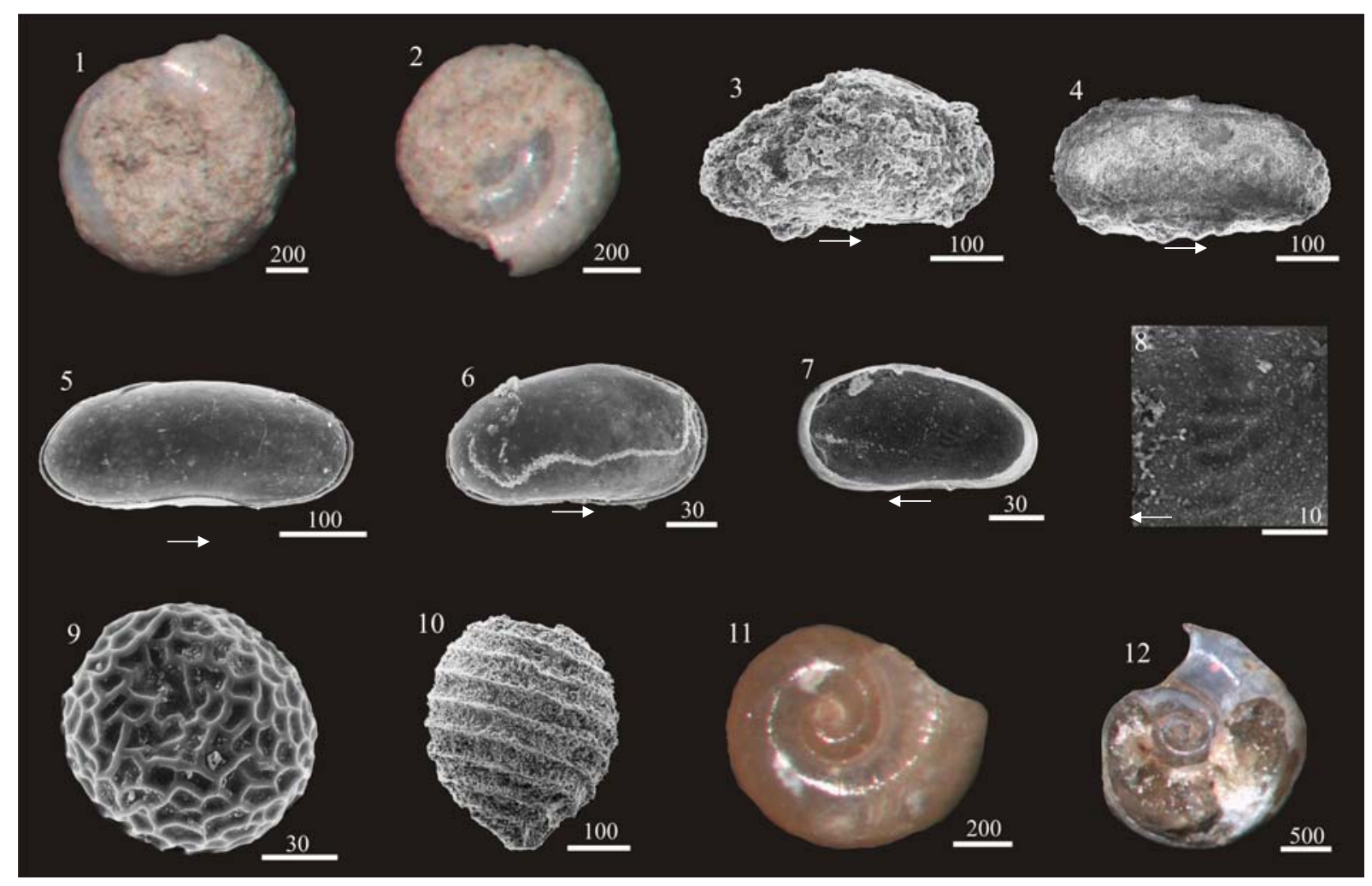




\section{ANEXOS}


FÓSSEIS EM MICRITOS DA SERRA DA BODOQUENA, BONITO-MS E SUAS CONTRIBUIÇÕES PARA AS RECONSTITUIÇÕES PALEOAMBIENTAIS E IDADES DE DEPOSIÇÃO

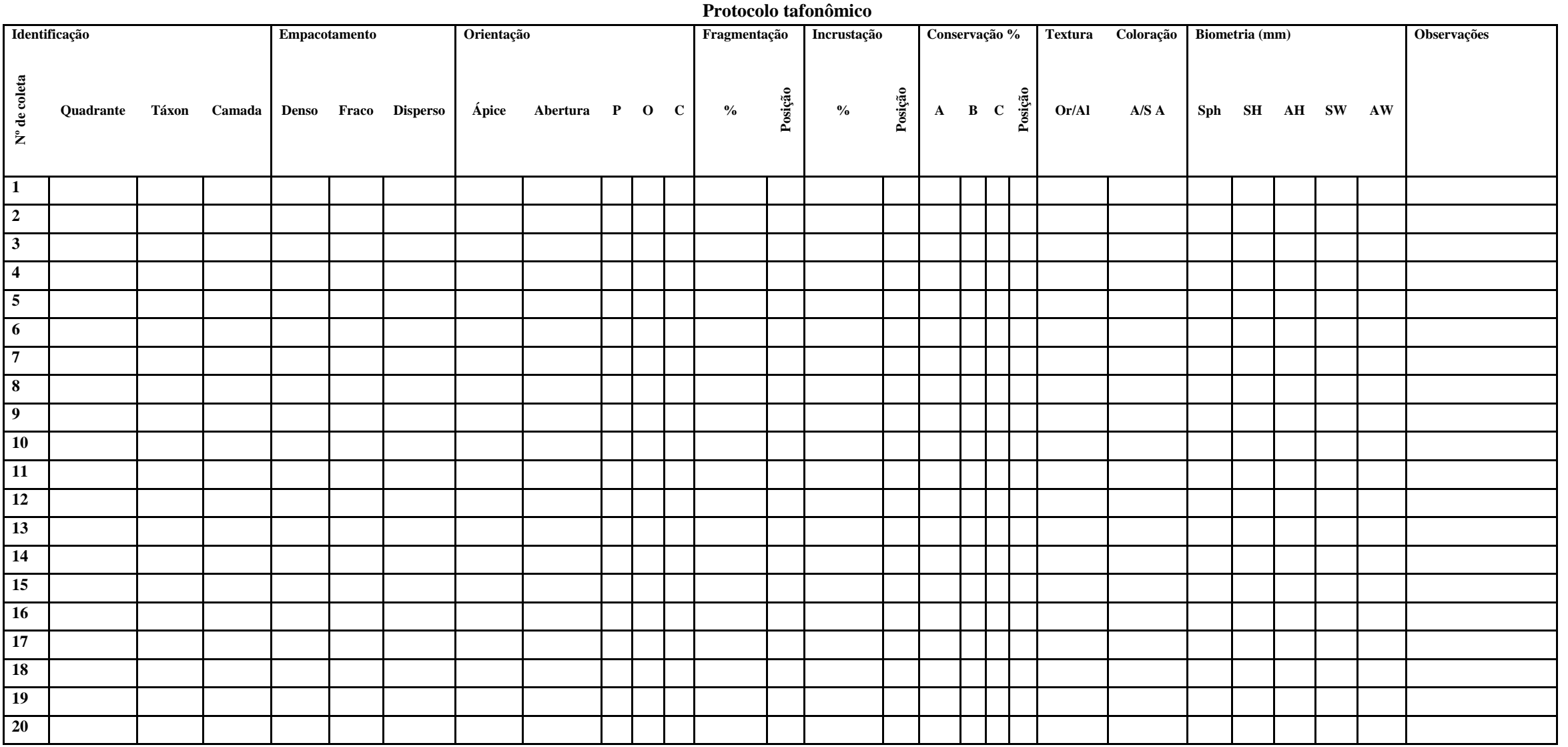

Legenda:

Orientação: P: Perpendicular; O: Oblíquo; C: Concordante

Posição da abertura da concha: 1: para cima; 2: para baixo

Posição da abertura da concha em relação ao Norte: 3: deslocada para cima; 4: deslocada para baixo; 0: sem deslocamento Incrustação: a princípio a incrustação existente é de precipitação de carbonato
Conservação: A: abrasão, B: bioerosão, C: Corrosão

Textura: Or: Original; Al: Alterada; B: Branca; M: Marcas Biometria: Sph: Altura do ápice; SH: Altura da Coloração: Al: Alterada; SA: Sem alterações concha; AH: Altura da abertur SW: Largura da concha; AW: Largura d

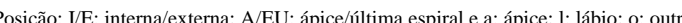

Para: Fragmentação, Incrustação por carbonato e Corrosão indicar índices: <10\%, 10-50\%, 50-90\% ou >90\%. 
Anexo B - Análise química e de elementos menores e traço das amostras do perfil da Mineração Calcário Xaraés. Elementos e óxidos obtidos da análise de fluorescência de Raio-X. Loi: Perda ao fogo. JB 1a, IPT-48 e LD: padrões. Nº: Número de referência do laboratório. Rec.: Resultado recomendado. “<”: concentração abaixo do limite de detecção do equipamento. Óxidos obtidos em porcentagem. Elementos obtidos em ppm.

\begin{tabular}{|c|c|c|c|c|c|c|c|c|c|c|c|c|c|c|c|c|c|c|c|c|}
\hline \multicolumn{21}{|c|}{ Análise composicional do perfil da Mineração Calcário Xaraés } \\
\hline Perfil (m) & $\overline{5,16}$ & 4,66 & 3,96 & \multicolumn{2}{|c|}{3,46} & \multirow{2}{*}{$\begin{array}{c}2,96 \\
07 / 1096\end{array}$} & \multirow{2}{*}{$\begin{array}{c}2,36 \\
07 / 1097\end{array}$} & \multirow{2}{*}{$\begin{array}{c}2,18 \\
08 / 338 \\
\end{array}$} & \multirow{2}{*}{$\begin{array}{c}2,08 \\
07 / 1098\end{array}$} & \multirow{2}{*}{$\begin{array}{c}1,94 \\
07 / 1099\end{array}$} & \multicolumn{2}{|c|}{1,38} & \multirow{2}{*}{$\begin{array}{c}1,06 \\
07 / 1101\end{array}$} & \multirow{2}{*}{$\begin{array}{c}0,51 \\
07 / 1102\end{array}$} & \multirow{2}{*}{$\begin{array}{c}0,00 \\
07 / 1103\end{array}$} & \multicolumn{2}{|c|}{$J B 1 a$} & \multicolumn{2}{|c|}{ CAL-S } & \multirow{2}{*}{$L D$} \\
\hline $\mathrm{N}^{\circ}$ & 07/1092 & 07/1093 & 07/1094 & /1095a & 07/1095b & & & & & & 07/1100a & 07/1100b & & & & Obtida & Rec. & Obtida & Rec. & \\
\hline \multicolumn{21}{|c|}{ Óxidos } \\
\hline $\mathrm{SiO}_{2}$ & 1,49 & 0,12 & 0,39 & $<0.03$ & $<0.03$ & $<0.03$ & 1,25 & 2,90 & 2,30 & 1,32 & 0,31 & 0,32 & 34,55 & 34,34 & 34,79 & 52,86 & 52,16 & $<0.03$ & & 0,03 \\
\hline $\mathrm{Al}_{2} \mathrm{O}_{3}$ & 1,27 & 0,42 & 0,62 & 0,13 & 0,12 & 0,09 & 1,03 & 1,46 & 1,57 & 1,12 & 0,53 & 0,53 & 12,79 & 9,05 & 6,84 & 14,53 & 14,51 & $<0.01$ & & 0,01 \\
\hline $\mathrm{MnO}$ & 0,009 & 0,007 & 0,009 & 0,006 & 0,006 & 0,006 & 0,011 & 0,014 & 0,017 & 0,022 & 0,027 & 0,028 & 0,122 & 0,045 & 0,025 & 0,149 & 0,15 & 0,004 & & 0,002 \\
\hline $\mathrm{MgO}$ & 0,23 & 0,19 & 0,20 & 0,19 & 0,19 & 0,19 & 0,19 & 0,22 & 0,19 & 0,18 & 0,17 & 0,16 & 0,63 & 0,48 & 0,38 & 7,56 & 7,75 & 0,40 & 0,39 & 0,01 \\
\hline $\mathrm{CaO}$ & 52,59 & 54,33 & 53,91 & 54,94 & 54,92 & 55,04 & 53,38 & 52,02 & 51,94 & 53,33 & 54,28 & 54,44 & 21,17 & 25,64 & 28,04 & 9,37 & 9,23 & 55,63 & 55,53 & 0,01 \\
\hline $\mathrm{Na}_{2} \mathrm{O}$ & $<0.02$ & $=0.02$ & $<0.02$ & $<0.02$ & $<0.02$ & $<0.02$ & $<0.02$ & $<0,02$ & $<0.02$ & 0.02 & 0.02 & $<0.02$ & 0,06 & 0,04 & 0,11 & 2,74 & 2,74 & $<0.02$ & & 0,02 \\
\hline $\mathrm{K} 2 \mathrm{O}$ & 0,06 & 0,02 & 0,03 & $<0.01$ & 0,01 & 0,00 & 0,04 & 0,07 & 0,07 & 0,04 & 0,02 & 0,02 & 0,65 & 0,52 & 0,42 & 1,39 & 1,42 & $<0.01$ & & 0,01 \\
\hline $\mathrm{TiO}_{2}$ & 0,066 & 0,031 & 0,036 & 0,017 & 0,011 & 0,010 & 0,057 & 0,087 & 0,093 & 0,061 & 0,030 & 0,030 & 0,719 & 0,572 & 0,469 & 1,312 & 1,3 & 0,004 & & 0,007 \\
\hline $\mathrm{P}_{2} \mathrm{O}_{5}$ & 0,097 & 0,070 & 0,060 & 0,041 & 0,040 & 0,043 & 0,075 & 0,047 & 0,060 & 0,054 & 0,028 & 0,031 & 0,076 & 0,054 & 0,043 & 0,257 & 0,26 & $<0.003$ & & 0,003 \\
\hline $\mathrm{Fe}_{2} \mathrm{O}_{3}$ & 0,40 & 0,23 & 0,38 & 0,23 & 0,23 & 0,16 & 0,46 & 0,51 & 0,53 & 0,39 & 0,26 & 0,26 & 5,97 & 3,70 & 2,64 & 9,05 & 9,1 & 0,03 & & 0,01 \\
\hline Loi & 43,30 & 43,63 & 44,40 & 43,91 & 43,84 & 43,85 & 42,79 & 42,03 & 42,32 & 42,89 & 43,78 & 42,54 & 22,75 & 24,82 & 25,71 & 1,1 & 1,1 & 43,75 & 43,75 & 0,01 \\
\hline Total & 99,51 & 99,05 & 100,04 & 99,46 & 99,37 & 99,39 & 99,28 & 99,36 & 99,09 & 99,41 & 99,44 & 98,36 & 99,49 & 99,26 & 99,47 & 100,32 & 99,72 & 99,82 & 99,67 & \\
\hline \multicolumn{21}{|c|}{ Elementos } \\
\hline$B a$ & 37 & $<3$ & 37 & 37 & $<3$ & $<37$ & 51 & 45 & $<37$ & $<37$ & 37 & 37 & 18 & 117 & 80 & 529 & 7 & & & 37 \\
\hline $\mathrm{Ce}$ & $<35$ & $<35$ & $<35$ & $<35$ & $<35$ & 42 & 36 & $<35$ & $<35$ & 39 & $<35$ & $<35$ & 65 & 70 & 40 & 75 & 66,1 & & 0,4 & 35 \\
\hline $\mathrm{Cl}$ & $<50$ & $<50$ & $<50$ & $<50$ & $<50$ & $<50$ & $<50$ & $<50$ & $<50$ & $<50$ & $<50$ & $<50$ & $<50$ & $<50$ & $<50$ & 138 & 0 & & & 50 \\
\hline Co & $<6$ & $<6$ & $<6$ & $<6$ & $<6$ & $<6$ & $<6$ & $<6$ & $<6$ & $<6$ & $<6$ & $<6$ & 11 & 7 & 6 & 36 & 39,5 & $<6$ & 0,8 & 6 \\
\hline $\mathrm{Cr}$ & $<13$ & $<13$ & $<13$ & $<13$ & $<13$ & $<13$ & $<13$ & $<13$ & $<13$ & $<13$ & $<13$ & $<13$ & 60 & 83 & 38 & 407 & 5 & & 9 & 13 \\
\hline $\mathrm{Cu}$ & & $<5$ & $<5$ & & $<5$ & & & $<5$ & $<$ & $<5$ & $<5$ & & 16 & 12 & 8 & 56 & & $<5$ & 0,013 & 5 \\
\hline$F$ & 617 & 449 & 711 & $<550$ & 669 & $<550$ & $<550$ & $<3024$ & 794 & $<550$ & 559 & 627 & 716 & 884 & 759 & $<550$ & 385 & $<550$ & & 550 \\
\hline$G a$ & $<9$ & $<9$ & & $<9$ & & & & $<9$ & $<9$ & $<9$ & & & 18 & 13 & 9 & 18 & & & & 9 \\
\hline $\mathrm{La}$ & $<28$ & $<28$ & $<28$ & $<28$ & $<28$ & $<28$ & $<28$ & $<28$ & $<28$ & $<28$ & $<28$ & $<28$ & 29 & $<28$ & $<28$ & 30 & 38 & $<28$ & 0,89 & 28 \\
\hline$N b$ & $<\quad 9$ & $<\quad 9$ & $<9$ & $<9$ & $<\quad 9$ & $<\quad 9$ & $<\quad 9$ & $<9$ & $<\quad 9$ & $<9$ & $<\quad 9$ & $<\quad 9$ & $<\quad 9$ & $<9$ & $<\quad 9$ & 27 & $\begin{array}{r}0,1 \\
27\end{array}$ & & & 9 \\
\hline$N d$ & $<14$ & $<14$ & $<14$ & $<14$ & $<14$ & $<14$ & $<14$ & 16 & $<14$ & $<14$ & $<14$ & $<14$ & $<14$ & $<14$ & $<14$ & 25 & 25,5 & $<14$ & 0,39 & 14 \\
\hline $\mathrm{Ni}$ & $<5$ & $<5$ & $<5$ & $<5$ & $<5$ & $<5$ & $<5$ & $<5$ & $<5$ & $<5$ & $<5$ & $<5$ & 19 & 15 & 12 & 144 & 0 & $<5$ & & 5 \\
\hline$P b$ & 22 & 17 & 18 & 15 & 14 & 16 & 16 & 19 & 16 & 16 & 15 & 17 & 0 & 29 & - & & 7,2 & 12 & & 4 \\
\hline$R b$ & 8 & 3 & 5 & $<3$ & $<3$ & $<3$ & 6 & 10 & 9 & 6 & 3 & & 80 & 53 & 43 & 38 & 41 & & & 3 \\
\hline$S$ & $<300$ & $<300$ & $<300$ & $<300$ & $<300$ & $<300$ & $<300$ & $<300$ & $<300$ & $<300$ & $<300$ & $<300$ & $<300$ & $<300$ & $<300$ & $<300$ & 9 & $<300$ & & 300 \\
\hline Sc & 14 & 17 & o & 17 & 15 & 20 & 14 & 54 & 16 & 17 & 18 & 19 & 14 & $<14$ & $<14$ & 30 & 9 & 17 & & 14 \\
\hline Sr & 652 & 621 & 56 & 538 & 53 & 641 & 537 & 5 & 541 & 520 & 525 & 525 & 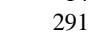 & 281 & 299 & 455 & & 225 & 233,3 & . \\
\hline$T h$ & 30 & 27 & 23 & 23 & 00 & 22 & 24 & 28 & 22 & 24 & 26 & 27 & 22 & 23 & 18 & 11 & & 21 & & 7 \\
\hline$m$ & 41 & 38 & 35 & 34 & 36 & 38 & 34 & 14 & 35 & 35 & 35 & 37 & 19 & 21 & 20 & $<3$ & & 31 & 0,82 & 3 \\
\hline V & 17 & 0 & 19 & 12 & $<9$ & $<9$ & $<9$ & 21 & $<9$ & 23 & $<9$ & 12 & 78 & 63 & 41 & 191 & 22 & 12 & & \\
\hline$Y$ & 5 & 4 & 5 & 4 & 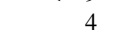 & 3 & 5 & 7 & 7 & 6 & 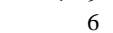 & 6 & 21 & 20 & 18 & 24 & 24 & 4 & 2,2 & 2 \\
\hline $\mathrm{Zn}$ & 13 & 9 & 10 & 7 & 8 & 7 & 8 & 1 ? & 12 & 12 & 3 & $y$ & 40 & 32 & 24 & 82 & 82 & 19 & 15 & 2 \\
\hline $\mathrm{Zr}$ & 15 & 10 & 12 & 9 & 8 & 8 & 18 & 25 & 25 & 18 & 12 & 12 & 189 & 193 & 175 & 138 & 146 & 8 & & \\
\hline
\end{tabular}


Anexo C - Análise química e de elementos menores e traços das amostras dos demais depósitos de micritos da Serra da Bodoquena. Elementos e óxidos obtidos da análise de fluorescência de Raio-X. Loi: Perda ao fogo. JB 1a, IPT-48 e LD: padrões. Nº Lab.: Número de referência do laboratório. Óxidos obtidos em porcentagem.Elementos obtidos em ppm.

\begin{tabular}{|c|c|c|c|c|c|c|c|c|c|c|c|c|}
\hline \multicolumn{13}{|c|}{ álise composicional dos depósitos de micritos da Serra da Bodoquena } \\
\hline $\begin{array}{c}\text { Amostras } \\
\mathrm{N}^{\circ} \mathrm{Lab}\end{array}$ & $\begin{array}{r}04 \\
08 / 342 a^{-1}\end{array}$ & $\begin{array}{l}A \\
08 / 342 b\end{array}$ & $\begin{array}{c}06 A \\
08 / 340\end{array}$ & $\begin{array}{c}07 A \\
08 / 341\end{array}$ & $\begin{array}{c}14 A \\
07 / 1104\end{array}$ & $\begin{array}{c}16 B \\
07 / 1107\end{array}$ & $\begin{array}{c}16 D \\
08 / 339\end{array}$ & Obtida & $\begin{array}{l}J B 1 a \\
\text { Recomendada }\end{array}$ & $\begin{array}{l}\text { IPT-48 } \\
\text { Obtida }\end{array}$ & Recomendada & $L D$ \\
\hline \multicolumn{13}{|c|}{ Óxidos } \\
\hline $\mathrm{SiO}_{2}$ & 15,67 & 15,73 & 29,84 & 0.03 & 35,65 & 0.03 & 1,95 & 52,66 & 52,16 & 0,45 & 0,45 & 0,03 \\
\hline $\mathrm{Al}_{2} \mathrm{O}_{3}$ & 3,56 & 3,58 & 3,16 & 0.03 & 6,71 & 0.01 & 0,28 & 14,58 & 14,51 & 0,16 & 0,17 & 0,01 \\
\hline $\mathrm{MnO}$ & 0,022 & 0,021 & 0,030 & 0,076 & 0,023 & 0.002 & 0,007 & 0,150 & 0,15 & 0,014 & 0,014 & 0,002 \\
\hline $\mathrm{MgO}$ & 1,42 & 1,40 & 1,12 & 0,17 & 1,22 & 1,59 & 1,53 & 7,84 & 7,75 & 21,4 & 21,2 & 0,01 \\
\hline $\mathrm{CaO}$ & 40,43 & 40,58 & 32,56 & 55,05 & 25,79 & 52,92 & 51,82 & 9,3 & 9,23 & 31,3 & 31 & 0,01 \\
\hline $\mathrm{Na}_{2} \mathrm{O}$ & 0,07 & 0,06 & 0,19 & 0.02 & 0,26 & 0.02 & 0.02 & 2,7 & 2,74 & 0,07 & 0,013 & 0,02 \\
\hline $\mathrm{K}_{2} \mathrm{O}$ & 0,73 & 0,75 & 0,72 & 0.01 & 0,99 & 0.01 & 0,06 & 1,38 & 1,42 & 0,03 & 0,026 & 0,01 \\
\hline $\mathrm{TiO}_{2}$ & 0,164 & 0,164 & 0,178 & 0.007 & 0,405 & 0,005 & 0,032 & 1,320 & 1,3 & 0,007 & 0,006 & 0,007 \\
\hline $\mathrm{P}_{2} \mathrm{O}_{5}$ & 0,076 & 0,077 & 0,086 & 0,005 & 0,138 & 0,055 & 0,051 & 0,254 & 0,26 & 0,049 & 0,022 & 0,003 \\
\hline $\mathrm{Fe}_{2} \mathrm{O}_{3}$ & 1,34 & 1,34 & 1,25 & 0,36 & 2,54 & 0,05 & 0,24 & 9,03 & 9,1 & 0,18 & 0,017 & 0,01 \\
\hline Loi & 36,09 & 36,12 & 31,01 & 44,20 & 25,75 & 44,61 & 43,24 & 1,1 & 1,1 & 46,9 & 46,9 & 0,01 \\
\hline Total & 99,57 & 99,82 & 100,14 & 99,86 & 99,48 & 99,23 & 99,21 & 100,31 & 99,72 & 100,56 & 99,82 & \\
\hline \multicolumn{13}{|c|}{ Elementos } \\
\hline $\mathrm{Ba}$ & 210 & 190 & 210 & 51 & 191 & 47 & 70 & 486 & 497 & & & 37 \\
\hline $\mathrm{Ce}$ & 35 & 35 & 35 & 35 & 58 & 37 & 66 & 84 & 66,1 & & & 35 \\
\hline $\mathrm{Cl}$ & 50 & 50 & 50 & 50 & 50 & 50 & 50 & $<50$ & 170 & & & 50 \\
\hline Co & 6 & 6 & 6 & 6 & 6 & 6 & 6 & 39 & 39,5 & & & 6 \\
\hline $\mathrm{Cr}$ & 14 & 13 & 17 & 13 & 81 & 13 & 13 & 414 & 415 & & & 13 \\
\hline $\mathrm{Cu}$ & 9 & 10 & 7 & 5 & 13 & 5 & 5 & 56 & 55,5 & & & 5 \\
\hline$F$ & 2357 & 2355 & 1784 & 3423 & 826 & 653 & 2962 & $<550$ & 385 & & & 550 \\
\hline$G a$ & 9 & 9 & 9 & 9 & 8 & 9 & 9 & 18 & 18 & & & 9 \\
\hline La & 28 & 28 & 28 & 28 & 31 & 28 & 28 & 44 & 38,1 & & & 28 \\
\hline$N b$ & 9 & 9 & 9 & 9 & 9 & 9 & 9 & 26 & 27 & & & 9 \\
\hline$N d$ & 29 & 14 & 25 & 18 & 14 & 14 & 14 & 37 & 25,5 & & & 14 \\
\hline $\mathrm{Ni}$ & 6 & 5 & 5 & 5 & 13 & 5 & 5 & 142 & 140 & & & 5 \\
\hline$P b$ & 13 & 14 & 12 & 17 & 14 & 14 & 11 & $<4$ & 7,2 & & & 4 \\
\hline$R b$ & 37 & 37 & 34 & 3 & 63 & 3 & 7 & 39 & 41 & & & 3 \\
\hline$S$ & 300 & 300 & 319 & 300 & 300 & 300 & 300 & $<300$ & 9 & & & 300 \\
\hline Sc & 42 & 40 & 33 & 59 & 14 & 15 & 53 & 30 & 27,9 & & & 14 \\
\hline Sr & 76 & 78 & 57 & 891 & 89 & 41 & 43 & 461 & 443 & & & 2 \\
\hline$T h$ & 14 & 14 & 11 & 22 & 17 & 20 & 17 & 8 & 8,8 & & & 7 \\
\hline$U$ & 8 & 8 & 5 & 17 & 17 & 30 & 10 & $<3$ & 1,6 & & & 3 \\
\hline V & 28 & 28 & 22 & 9 & 39 & 9 & 9 & 214 & 220 & & & 9 \\
\hline$Y$ & 13 & 14 & 13 & 4 & 18 & 4 & 4 & 24 & 24 & & & 2 \\
\hline$Z n$ & 19 & 18 & 20 & 7 & 33 & 7 & 7 & 82 & 82 & & & 2 \\
\hline $\mathrm{Zr}$ & 70 & 70 & 89 & 3 & 137 & 15 & 17 & 141 & 146 & & & 2 \\
\hline
\end{tabular}


ANEXO D - Mapa geológico da Serra da Bodoquena- MS, Brasil e depósitos estudados. Pontos em preto indicam áreas de estudo. Pontos em vermelho indicam municípios. Modificado de: Sallun-Filho (2005).
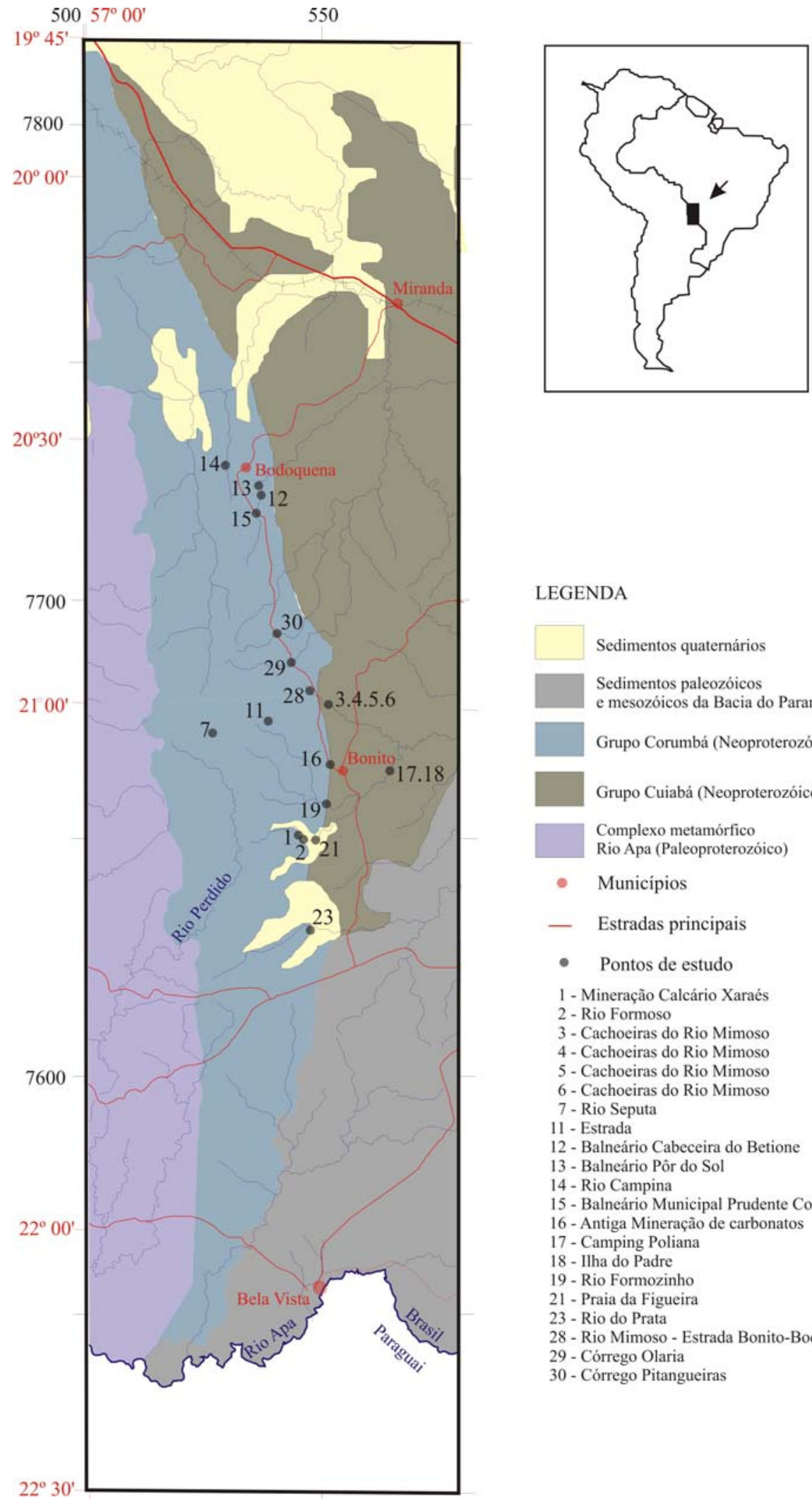

LEGENDA

$$
\begin{aligned}
& \text { Sedimentos quaternários } \\
& \text { Sedimentos paleozóicos } \\
& \text { e mesozóicos da Bacia do Paraná } \\
& \text { Grupo Corumbá (Neoproterozóico) } \\
& \text { Grupo Cuiabá (Neoproterozóico) } \\
& \text { Complexo metamórfico } \\
& \text { Rio Apa (Paleoproterozóico) } \\
& \text { - Municípios } \\
& \text { - Estradas principais } \\
& \text { - Pontos de estudo }
\end{aligned}
$$




\begin{tabular}{|c|c|c|c|c|c|}
\hline \multicolumn{6}{|c|}{ ANEXO E } \\
\hline GP/1E & Ponto & Amostra & Procedência & Coletor & Descrição \\
\hline 5700 & 1 & 1 & $\begin{array}{l}\text { Formação Xaraiés, Mineração } \\
\text { Calcário Xaraés, Bonito, MS }\end{array}$ & $\begin{array}{l}\text { Patrícia C. } \\
\text { de Souza }\end{array}$ & $\begin{array}{l}\text { Conjunto de gastrópodes da espécie Pomacea canaliculata e } \\
\text { alguns jovens e fragmentos }\end{array}$ \\
\hline 5701 & 1 & 07TUF01 1 & $\begin{array}{l}\text { Formação Xaraiés, Mineração } \\
\text { Calcário Xaraés, Bonito, MS }\end{array}$ & Giselle Utida & Conjunto de gastrópodes do gênero Pomacea \\
\hline 5702 & 1 & 07TUF01 2 & $\begin{array}{l}\text { Formação Xaraiés, Mineração } \\
\text { Calcário Xaraés, Bonito, MS }\end{array}$ & Giselle Utida & Conjunto de gastrópodes do gênero Biomphalaria \\
\hline 5703 & 2 & Ponto 02 RM-1 & Formação Xaraiés, Rio Formoso, Bonito, MS & Giselle Utida & Gastrópodes da Família Thiaridae, possivelmente atuais \\
\hline 5704 & 4 & Ponto 04 CT2 & Formação Xaraiés, Rio Mimoso, Bonito, MS & Giselle Utida & Conjunto de gastrópodes do gênero Pomacea \\
\hline 5705 & 4 & Ponto 04 CT2 & Formação Xaraiés, Rio Mimoso, Bonito, MS & Giselle Utida & Conjunto de bivalves do gênero Diplodon \\
\hline 5706 & 7 & 07TUF07C & Formação Xaraiés, Rio Seputa, Bonito, MS & Giselle Utida & Conjunto de gastrópodes do gênero Pomacea \\
\hline 5708 & 12 & 07TUF12F 2 & Formação Xaraiés, Rio Betione, Bonito, MS & Giselle Utida & Conjunto de gastrópodes do gênero Biomphalaria \\
\hline 5709 & 12 & 07TUF12F 3 & Formação Xaraiés, Rio Betione, Bonito, MS & Giselle Utida & $\begin{array}{l}\text { Conjunto de gastrópodes da Família Hydrobiidae, possíveis } \\
\text { gêneros Idiopyrgus e Littoridina }\end{array}$ \\
\hline 5710 & 12 & $12 \mathrm{~F}$ & Formação Xaraiés, Rio Betione, Bonito, MS & Giselle Utida & Gastrópode do gênero Hyalina, possivelmente recente \\
\hline 5711 & 15 & 07TUF15A 1 & $\begin{array}{c}\text { Formação Xaraiés, Balneário Municipal } \\
\text { Prudente Corrêa, Bonito, MS }\end{array}$ & Giselle Utida & Conjunto de gastrópodes do gênero Pomacea \\
\hline 5712 & 15 & 07TUF15A 2 & $\begin{array}{l}\text { Formação Xaraiés, Balneário Municipal } \\
\text { Prudente Corrêa, Bonito, MS }\end{array}$ & Giselle Utida & Conjunto de gastrópodes do gênero Biomphalaria \\
\hline 5713 & 15 & 07TUF15A 3 & $\begin{array}{l}\text { Formação Xaraiés, Balneário Municipal } \\
\text { Prudente Corrêa, Bonito, MS }\end{array}$ & Giselle Utida & $\begin{array}{l}\text { Conjunto de gastrópodes da Família Hydrobiidae, possíveis } \\
\text { gêneros Idiopyrgus e Littoridina }\end{array}$ \\
\hline 5714 & 16 & 07TUF16A 1 & $\begin{array}{l}\text { Formação Xaraiés, Bonito, MS, anti } \\
\text { mineração de carbonatos, centro da cidade }\end{array}$ & Giselle Utida & Conjunto de gastrópodes do gênero Pomacea \\
\hline
\end{tabular}




\begin{tabular}{|c|c|c|c|c|c|}
\hline \multicolumn{6}{|c|}{ ANEXO E cont. } \\
\hline GP/1E & Ponto & Amostra & Procedência & Coletor & Descrição \\
\hline & & & & & \\
\hline 5715 & 16 & 07TUF16A 2 & $\begin{array}{l}\text { Formação Xaraiés, Bonito, MS, antiga } \\
\text { mineração de carbonatos, centro da cidade }\end{array}$ & Giselle Utida & Conjunto de gastrópodes do gênero Biomphalaria \\
\hline 5716 & 17 & 07TUF17C & Formação Xaraiés, Rio Formoso, Bonito, MS & Giselle Utida & Conjunto de gastrópodes do gênero Pomacea \\
\hline 5717 & 17 & 07TUF17C1 & Formação Xaraiés, Rio Formoso, Bonito, MS & Giselle Utida & 2 gastrópodes do gênero Pomacea \\
\hline 5718 & 17 & 07TUF17C2 & Formação Xaraiés, Rio Formoso, Bonito, MS & Giselle Utida & 3 gastrópodes do gênero Idiopyraus \\
\hline & & & & & \\
\hline 5719 & 17 & 07TUF17C3 & Formação Xaraiés, Rio Formoso, Bonito, MS & Giselle Utida & Conjunto de gastrópodes do gênero Biomphalaria \\
\hline 5720 & 38 & Ponto 38 & $\begin{array}{l}\text { Formação Xaraiés, Lentes do Pantanal do } \\
\text { Miranda, Estrada Parque Pantanal Sul, MS }\end{array}$ & Giselle Utida & Conjunto de gastrópodes do gênero Marisa \\
\hline 5721 & 1 & 07TUF01 & $\begin{array}{l}\text { Formação Xaraiés, Mineração } \\
\text { Calcário Xaraés, Bonito, MS }\end{array}$ & $\begin{array}{l}\text { Patrícia C. } \\
\text { de Souza }\end{array}$ & Gastrópode do gênero Bulimulus \\
\hline 5722 & 1 & C1,0-1,5.1 & $\begin{array}{l}\text { Formação Xaraiés, Mineração } \\
\text { Calcário Xaraés, Bonito, MS }\end{array}$ & Giselle Utida & Conjunto de gastrópodes do gênero Pomacea e fragmentos \\
\hline & & & & & \\
\hline 5723 & 1 & C1,0-1,5.2 & $\begin{array}{l}\text { Formação Xaraiés, Mineração } \\
\text { Calcário Xaraés, Bonito, MS }\end{array}$ & Giselle Utida & Conjunto de gastrópodes do gênero Biomphalaria \\
\hline 5724 & 1 & C1,0-1,5.3 & $\begin{array}{l}\text { Formação Xaraiés, Mineração } \\
\text { Calcário Xaraés, Bonito, MS }\end{array}$ & Giselle Utida & Conjunto de gastrópodes do gênero Idiopyrgus \\
\hline 5725 & 1 & C2,0-2,5.1 & $\begin{array}{l}\text { Formação Xaraiés, Mineração } \\
\text { Calcário Xaraés, Bonito, MS }\end{array}$ & Giselle Utida & Conjunto de gastrópodes do gênero Pomacea \\
\hline 5726 & 1 & C2,0-2,5.2 & $\begin{array}{l}\text { Formação Xaraiés, Mineração } \\
\text { Calcário Xaraés, Bonito, MS }\end{array}$ & Giselle Utida & Conjunto de gastrópodes do gênero Biomphalaria \\
\hline 5727 & 1 & C2,0-2,5.3 & $\begin{array}{l}\text { Formação Xaraiés, Mineração } \\
\text { Calcário Xaraés, Bonito, MS }\end{array}$ & Giselle Utida & Conjunto de gastrópodes do gênero Idiopyrgus \\
\hline 5728 & 16 & 07TUF16B & $\begin{array}{c}\text { Formação Xaraiés, Antiga Mineração } \\
\text { de Calcários, Bonito, MS }\end{array}$ & Giselle Utida & Fragmentos de conchas de moluscos \\
\hline & & & & & \\
\hline
\end{tabular}




\begin{tabular}{|c|c|c|c|c|c|}
\hline \multicolumn{6}{|c|}{ ANEXO E cont. } \\
\hline GP/1E & Ponto & Amostra & Procedência & Coletor & Descrição \\
\hline 5729 & 1 & C0,5-1,0 & $\begin{array}{l}\text { Formação Xaraiés, Mineração } \\
\text { Calcário Xaraés, Bonito, MS }\end{array}$ & Giselle Utida & Conjunto de gastrópodes do gênero Biomphalaria \\
\hline 5730 & 1 & C0,0-0,5 & $\begin{array}{l}\text { Formação Xaraiés, Mineração } \\
\text { Calcário Xaraés, Bonito, MS }\end{array}$ & Giselle Utida & $\begin{array}{l}\text { Conjunto de gastrópodes do gênero Biomphalaria e do gênero } \\
\text { Pomacea }\end{array}$ \\
\hline 5731 & 1 & $\mathrm{C} 1,5-2,0.1$ & $\begin{array}{l}\text { Formação Xaraiés, Mineração } \\
\text { Calcário Xaraés, Bonito, MS }\end{array}$ & Giselle Utida & Conjunto de gastrópodes do gênero Pomacea \\
\hline 5732 & 1 & $\mathrm{C} 1,5-2,0.2$ & $\begin{array}{l}\text { Formação Xaraiés, Mineração } \\
\text { Calcário Xaraés, Bonito, MS }\end{array}$ & Giselle Utida & Conjunto de gastrópodes do gênero Biomphalaria \\
\hline 5733 & 1 & C1,5-2,0.3 & $\begin{array}{l}\text { Formação Xaraiés, Mineração } \\
\text { Calcário Xaraés, Bonito, MS }\end{array}$ & Giselle Utida & Um indivíduo de Bulimulus \\
\hline 5734 & 4 & 07TUF04A & $\begin{array}{l}\text { Formação Xaraiés, Cachoeiras } \\
\text { do Mimoso, Bonito, MS }\end{array}$ & Giselle Utida & $\begin{array}{l}\text { Conjunto de moluscos, Psidium, gastrópode da Subordem } \\
\text { Elasmognata, gastrópode da Família Ancylidae }\end{array}$ \\
\hline 5735 & 4 & 07TUF04A & $\begin{array}{l}\text { Formação Xaraiés, Cachoeiras } \\
\text { do Mimoso, Bonito, MS }\end{array}$ & Giselle Utida & Conjunto de gastrópodes, Biomphalaria e Família Hydrobiidae \\
\hline 5736 & 4 & 07TUF04A & $\begin{array}{l}\text { Formação Xaraiés, Cachoeiras } \\
\text { do Mimoso, Bonito, MS }\end{array}$ & Giselle Utida & Gastrópode do gênero Pomacea \\
\hline 5737 & 6 & 07TUF06A & $\begin{array}{l}\text { Formação Xaraiés, Cachoeiras } \\
\text { do Mimoso, Bonito, MS }\end{array}$ & Giselle Utida & Conjunto de bivalves do gênero Psidium \\
\hline 5738 & 6 & 07TUF06A & $\begin{array}{l}\text { Formação Xaraiés, Cachoeiras } \\
\text { do Mimoso, Bonito, MS }\end{array}$ & Giselle Utida & Conjunto de moluscos, Diplodon, Pomacea, Biomphalaria \\
\hline 5739 & 6 & 07TUF06A & $\begin{array}{c}\text { Formação Xaraiés, Cachoeiras } \\
\text { do Mimoso, Bonito, MS }\end{array}$ & Giselle Utida & Conjunto de gastrópodes da Família Hydrobiidae \\
\hline
\end{tabular}




\begin{tabular}{|c|c|c|c|c|c|c|}
\hline \multicolumn{4}{|c|}{$N^{o}$ de entrada GP/5E 4068} & \multicolumn{3}{|r|}{ ANEXO F } \\
\hline Quadrante & Linha & $\begin{array}{c}\text { Posição no } \\
\text { perfil (m) }\end{array}$ & Amostras & Proveniência & Coletor & Descrição \\
\hline & & & & & & \\
\hline 1 & 1 & 5,16 & $\mathrm{C} 2,0-2,5$ & $\begin{array}{l}\text { Formação Xaraiés, Mineração } \\
\text { Calcário Xaraés, Bonito, MS } \\
\text { UTM: 544652; } 7650534\end{array}$ & $\begin{array}{l}\text { Giselle } \\
\text { Utida }\end{array}$ & $\begin{array}{l}4 \text { Estruturas globulares, duas desconhecidas, } \\
\text { Heliozoa, provavel ovo de ostracode }\end{array}$ \\
\hline & & & & & & \\
\hline 1 & 2 & 4,46 & $\mathrm{C} 1,5-2,0$ & $\begin{array}{c}\text { Formação Xaraiés, Mineração } \\
\text { Calcário Xaraés, Bonito, MS } \\
\text { UTM: 544652; } 7650534\end{array}$ & $\begin{array}{l}\text { Giselle } \\
\text { Utida }\end{array}$ & $\begin{array}{l}\text { Gastrópode não identificado, gastrópode do } \\
\text { gênero Biomphalaria }\end{array}$ \\
\hline & & & & & & \\
\hline 2 & 1 & 3,46 & C $0,5-1,0$ & $\begin{array}{l}\text { Formação Xaraiés, Mineração } \\
\text { Calcário Xaraés, Bonito, MS } \\
\text { UTM: 544652; } 7650534\end{array}$ & $\begin{array}{l}\text { Giselle } \\
\text { Utida }\end{array}$ & $\begin{array}{l}\text { Gastrópode não identificado, gastrópode do } \\
\text { gênero Biomphalaria }\end{array}$ \\
\hline & & & & & & \\
\hline 2 & 2 & 3,96 & C $1,0-1,5$ & $\begin{array}{l}\text { Formação Xaraiés, Mineração } \\
\text { Calcário Xaraés, Bonito, MS } \\
\text { UTM: 544652; } 7650534\end{array}$ & $\begin{array}{l}\text { Giselle } \\
\text { Utida }\end{array}$ & Ostracodes, Darwinula, Cypria, indeterminado \\
\hline & & & & & & \\
\hline 3 & 1 & 1,94 & T72-82 & $\begin{array}{c}\text { Formação Xaraiés, Mineração } \\
\text { Calcário Xaraés, Bonito, MS } \\
\text { UTM: 544652; } 7650534\end{array}$ & $\begin{array}{l}\text { Giselle } \\
\text { Utida }\end{array}$ & $\begin{array}{l}\text { Girogonite do gênero Chara forma 3, gastrópode } \\
\text { indeterminado, ostracode do gênero Darwinula }\end{array}$ \\
\hline & & & & & & \\
\hline 3 & 2 & 2,08 & T58-63 & $\begin{array}{l}\text { Formação Xaraiés, Mineração } \\
\text { Calcário Xaraés, Bonito, MS } \\
\text { UTM: 544652; } 7650534\end{array}$ & $\begin{array}{l}\text { Giselle } \\
\text { Utida }\end{array}$ & $\begin{array}{c}\text { Girognites do gênero Chara forma 3, gastrópodes } \\
\text { do gênero Acrobis }\end{array}$ \\
\hline & & & & & & \\
\hline 3 & 3 & 2,08 & T58-63 & $\begin{array}{l}\text { Formação Xaraiés, Mineração } \\
\text { Calcário Xaraés, Bonito, MS } \\
\text { UTM: 544652; } 7650534\end{array}$ & $\begin{array}{l}\text { Giselle } \\
\text { Utida }\end{array}$ & $\begin{array}{l}\text { Girogonite do gênero Chara, ostracode indeterminado, } \\
\text { ostracode do gênero Darwinula }\end{array}$ \\
\hline & & & & & & \\
\hline 4 & 1 & 2,18 & T48-58 & $\begin{array}{c}\text { Formação Xaraiés, Mineração } \\
\text { Calcário Xaraés, Bonito, MS } \\
\text { UTM: 544652; } 7650534\end{array}$ & $\begin{array}{l}\text { Giselle } \\
\text { Utida }\end{array}$ & $\begin{array}{l}\text { Espícula de porifera, } 2 \text { ostracodes do gênero Darwinula, } \\
4 \text { ostracodes do gênero Candona }\end{array}$ \\
\hline & & & & & & \\
\hline
\end{tabular}




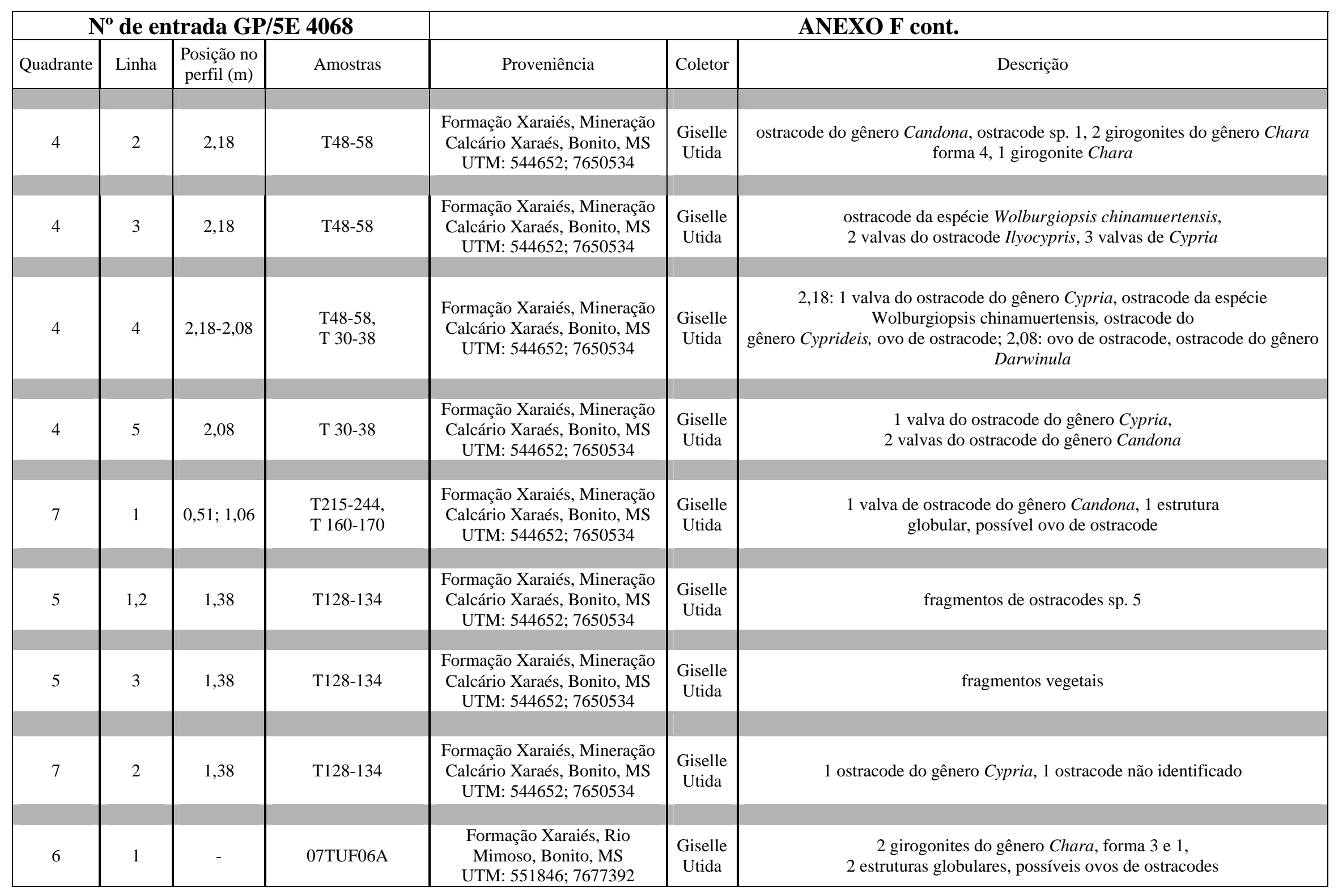




\begin{tabular}{|c|c|c|c|c|c|c|}
\hline \multicolumn{4}{|c|}{$\mathrm{N}^{0}$ de entrada GP/5E 4068} & \multicolumn{3}{|r|}{ ANEXO F cont. } \\
\hline Quadrante & Linha & $\begin{array}{c}\text { Posição no } \\
\text { perfil (m) }\end{array}$ & Amostras & Proveniência & Coletor & Descrição \\
\hline & & & & & & \\
\hline 6 & 2 & - & 07TUF06A & $\begin{array}{l}\text { Formação Xaraiés, Rio } \\
\text { Mimoso, Bonito, MS } \\
\text { UTM: 551846; 7677392 }\end{array}$ & $\begin{array}{l}\text { Giselle } \\
\text { Utida }\end{array}$ & $\begin{array}{l}1 \text { estrutura não identificada, } 1 \text { possível espícula } \\
\text { de porifera, } 1 \text { estrutura não identificada }\end{array}$ \\
\hline & & & & & & \\
\hline 6 & 3 & - & 07TUF06A & $\begin{array}{l}\text { Formação Xaraiés, Rio } \\
\text { Mimoso, Bonito, MS } \\
\text { UTM: 551846; 7677392 }\end{array}$ & $\begin{array}{l}\text { Giselle } \\
\text { Utida }\end{array}$ & $\begin{array}{l}\text { Girogonites do gênero Chara, } 2 \text { girogonites forma } 3 \text {, } \\
2 \text { girogonites forma } 2\end{array}$ \\
\hline 6 & 4 & - & 07TUF06A & $\begin{array}{l}\text { Formação Xaraiés, Rio } \\
\text { Mimoso, Bonito, MS } \\
\text { UTM: 551846; } 7677392\end{array}$ & $\begin{array}{l}\text { Giselle } \\
\text { Utida }\end{array}$ & 1 girogonite do gênero Chara forma 3 \\
\hline & & & & & & \\
\hline 25 & 1 & - & 07TUF17A & $\begin{array}{l}\text { Sedimentos do Rio } \\
\text { Formoso, Bonito, MS } \\
\text { UTM: 564035; 7665028 }\end{array}$ & $\begin{array}{l}\text { Giselle } \\
\text { Utida }\end{array}$ & 3 possíveis tecamebas, 1 ostracode, 1 possível tecameba \\
\hline & & & & & & \\
\hline 25 & 2 & - & $\begin{array}{l}\text { 07TUF17A } \\
\text { /14A }\end{array}$ & $\begin{array}{c}\text { 17: Sedimentos do Rio } \\
\text { Formoso, 14: Formação } \\
\text { Xaraiés, Rio Campina, } \\
\text { Bonito, MS } \\
\text { UTM: 17: 564035; 7665028; } \\
\text { 14: 529466; } 7728054\end{array}$ & $\begin{array}{l}\text { Giselle } \\
\text { Utida }\end{array}$ & $\begin{array}{c}\text { 17: } 2 \text { giroginites, 14: } 1 \text { ovo de ostracode, } 1 \text { possível tecameba, } 1 \text { ovo de } \\
\text { ostracode }\end{array}$ \\
\hline & & & & & & \\
\hline 25 & 3 & - & 07TUF14A & $\begin{array}{l}\text { Formação Xaraiés, Rio } \\
\text { Campina, Bonito, MS } \\
\text { UTM: 14: 529466; } 7728054\end{array}$ & $\begin{array}{l}\text { Giselle } \\
\text { Utida }\end{array}$ & $\begin{array}{c}1 \text { ovo de ostracode, ostracode sp. 1, } 1 \text { ostracode não identificado, estruturas } \\
\text { globulares semelhantes a fungos }\end{array}$ \\
\hline & & t & & & & \\
\hline 26 & 1 & - & $\begin{array}{l}\text { 07TUF14A } \\
\text { /07A }\end{array}$ & $\begin{array}{l}\text { Formação Xaraiés, 14: } \\
\text { Rio Campina, 07: Rio } \\
\text { Seputa, Bonito, MS } \\
\text { UTM: 14: 529466; } 7728054\end{array}$ & $\begin{array}{l}\text { Giselle } \\
\text { Utida }\end{array}$ & $\begin{array}{l}\text { 14: } 1 \text { ostracode do gênero Darwinula, } 1 \text { ostracode sp. 2, } \\
\text { 07: } 1 \text { ostracode do gênero Cypridopsis, } 1 \text { ostracode do gênero Candona }\end{array}$ \\
\hline & & & & & & \\
\hline 26 & 2 & - & 07TUF07A & $\begin{array}{l}\text { Formação Xaraiés, Rio } \\
\text { Seputa, Bonito, MS } \\
\text { UTM: 526992; 7670727 }\end{array}$ & $\begin{array}{l}\text { Giselle } \\
\text { Utida }\end{array}$ & $\begin{array}{c}1 \text { ostracode do gênero Cyclocypris, } 1 \text { ostracode sp. 5, } 1 \text { possível estrutura } \\
\text { tubular }\end{array}$ \\
\hline & & & & & & \\
\hline
\end{tabular}




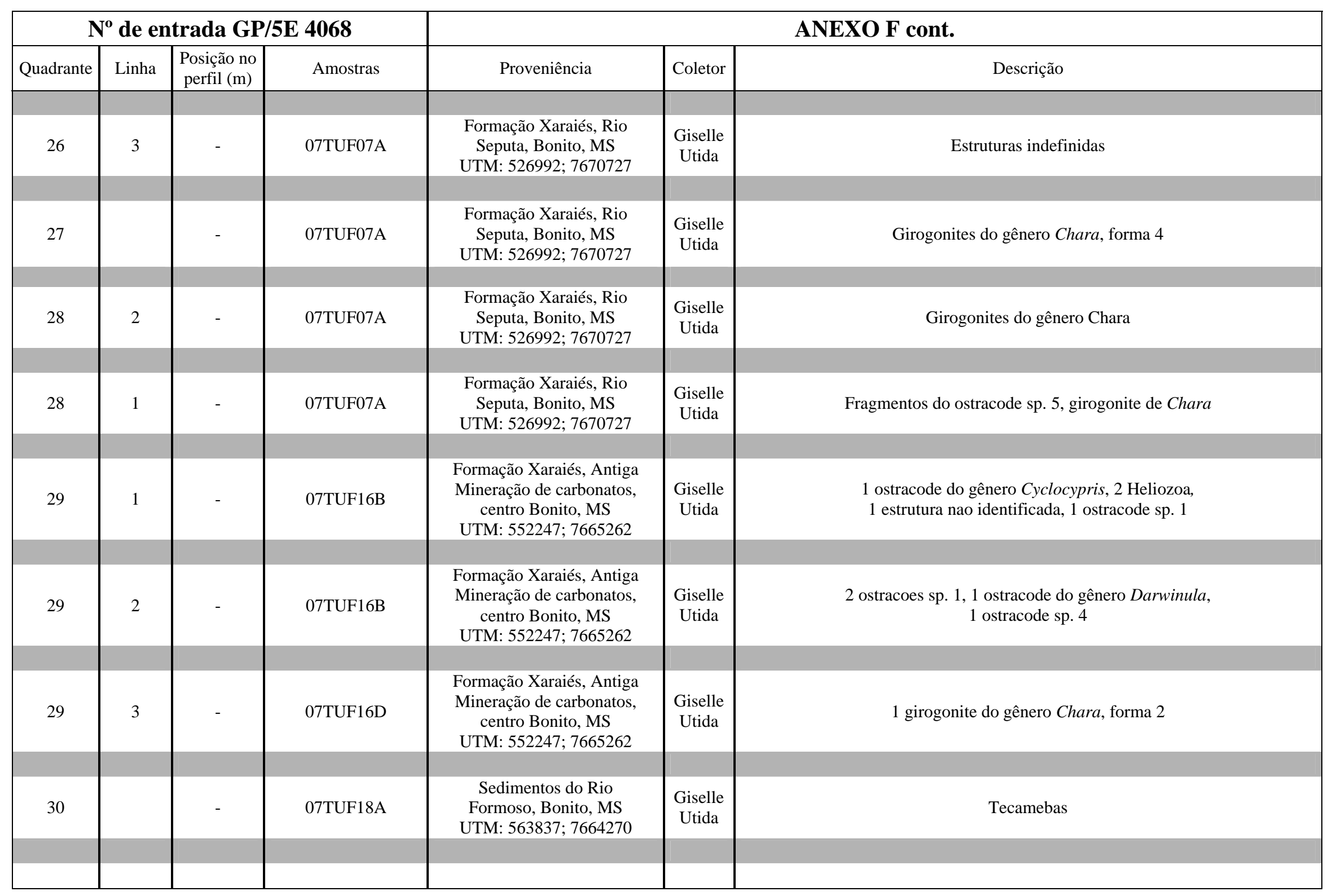




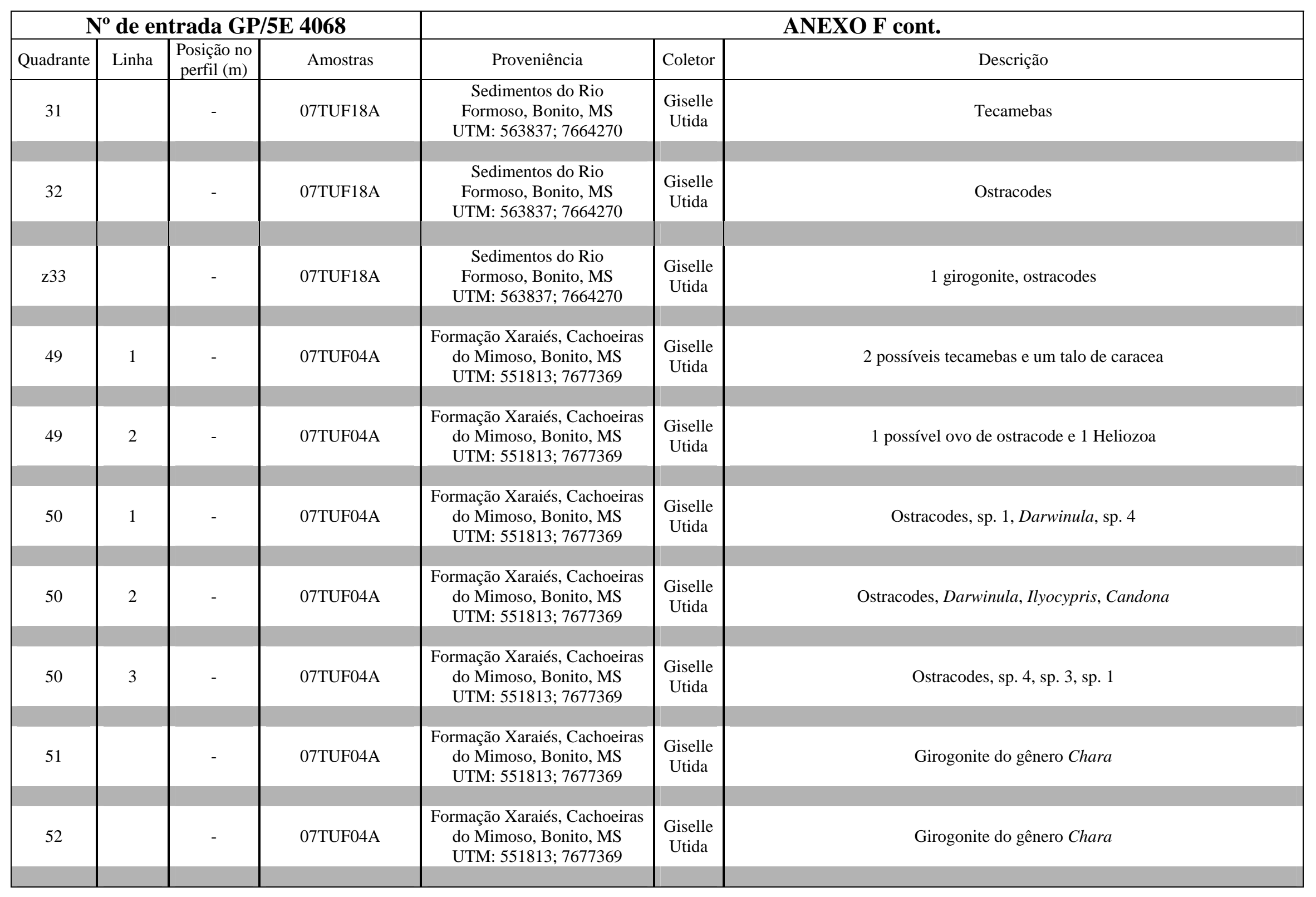




\begin{tabular}{|c|c|c|c|c|c|c|}
\hline \multicolumn{2}{|c|}{$\mathbf{N}^{\mathbf{0}}$ de entrada GP/5E 4068 } & \multicolumn{2}{|c|}{ ANEXO F cont. } \\
\hline Quadrante & Linha & $\begin{array}{c}\text { Posiç̃o no } \\
\text { perfil (m) }\end{array}$ & Amostras & Proveniência & Coletor & Descrição \\
\hline 53 & - & 07TUF04A & $\begin{array}{c}\text { Formação Xaraiés, Cachoeiras } \\
\text { do Mimoso, Bonito, MS } \\
\text { UTM: 551813; 7677369 }\end{array}$ & $\begin{array}{c}\text { Giselle } \\
\text { Utida }\end{array}$ & Girogonite do gênero Chara \\
\hline 54 & - & 07TUF04A & $\begin{array}{c}\text { Formação Xaraiés, Cachoeiras } \\
\text { do Mimoso, Bonito, MS } \\
\text { UTM: 551813; 7677369 }\end{array}$ & $\begin{array}{c}\text { Giselle } \\
\text { Utida }\end{array}$ \\
\hline 56 & - & 07TUF04A & $\begin{array}{c}\text { Formação Xaraiés, Cachoeiras } \\
\text { do Mimoso, Bonito, MS } \\
\text { UTM: 551813; 7677369 }\end{array}$ & $\begin{array}{c}\text { Giselle } \\
\text { Utida }\end{array}$ \\
\hline 57 & - & 07TUF04A & $\begin{array}{c}\text { Formação Xaraiés, Cachoeiras } \\
\text { do Mimoso, Bonito, MS } \\
\text { UTM: 551813; 7677369 }\end{array}$ & $\begin{array}{c}\text { Giselle } \\
\text { Utida }\end{array}$ & Girogonite do gênero Chara, forma 1 \\
\hline 55 & - & 07TUF04A & $\begin{array}{c}\text { Formação Xaraiés, Cachoeiras } \\
\text { do Mimoso, Bonito, MS } \\
\text { UTM: 551813; 7677369 }\end{array}$ & $\begin{array}{c}\text { Giselle } \\
\text { Utida }\end{array}$ & Girogonite do gênero Chara, forma 3 \\
\hline
\end{tabular}




\begin{tabular}{|c|c|c|c|c|c|c|}
\hline \multirow{2}{*}{ GP/5E } & \multirow{2}{*}{ Amostras } & \multirow{2}{*}{$\begin{array}{l}\text { Posição no } \\
\text { perfil (m) }\end{array}$} & \multicolumn{4}{|c|}{ ANEXO G } \\
\hline & & & Proveniência & Coletor & Quadrantes & Descrição \\
\hline \multirow{8}{*}{4069} & \multirow{8}{*}{ C2,0-2,5-B } & \multirow{8}{*}{5,16} & \multirow{8}{*}{$\begin{array}{c}\text { Formação Xaraiés, } \\
\text { Mineração Calcário Xaraés, } \\
\text { Bonito, MS } \\
\text { UTM: 544652; } 7650534\end{array}$} & \multirow{8}{*}{$\begin{array}{l}\text { Giselle } \\
\text { Utida }\end{array}$} & & \\
\hline & & & & & $\frac{1,2}{3}$ & $\begin{array}{l}\text { Gastrópodes do gênero Biomphalaria } \\
\text { Gastrópode indeterminado }\end{array}$ \\
\hline & & & & & 4 ao 7 & Gastrópodes da Família Hydrobiidae \\
\hline & & & & & 8 ao 15 & Gastrópodes do gênero Idiopyrgus \\
\hline & & & & & 16 & Gastrópode do gêneero Pomacea \\
\hline & & & & & 17 a 37 & Fragmentos de gastrópodes \\
\hline & & & & & 38,39 & Fragmentos vegetais \\
\hline & & & & & 40 ao 48 & Estrutura vegetal recorbeta por carbonato \\
\hline & & & & & & \\
\hline \multirow{10}{*}{4070} & \multirow{10}{*}{ C2,0-2,5-A } & \multirow{10}{*}{5,16} & \multirow{10}{*}{$\begin{array}{c}\text { Formação Xaraiés, } \\
\text { Mineração Calcário Xaraés, } \\
\text { Bonito, MS } \\
\text { UTM: 544652; } 7650534\end{array}$} & \multirow{10}{*}{$\begin{array}{l}\text { Giselle } \\
\text { Utida }\end{array}$} & 1,2 & Gastrópodes da Família Hydrobiidae \\
\hline & & & & & 3 & ? \\
\hline & & & & & 4 & Estruturas globulares \\
\hline & & & & & 5,13 ao 17,23 & Matéria orgânica \\
\hline & & & & & 59 & $?$ \\
\hline & & & & & 60 & Estrutura recoberta por carbonato, ostracode? \\
\hline & & & & & 58 & Fragmentos vegetais \\
\hline & & & & & 12,38 & Fragmentos de ostracodes ou gastrópodes \\
\hline & & & & & $10,11,34,37,47,49$ & Estruturas globulares \\
\hline & & & & & & Diversos fragmentos de gastrópodes \\
\hline & & & & & & \\
\hline \multirow{8}{*}{4071} & \multirow{8}{*}{ C1,5-2,0-A } & \multirow{8}{*}{4,46} & \multirow{8}{*}{$\begin{array}{c}\text { Formação Xaraiés, } \\
\text { Mineração Calcário Xaraés, } \\
\text { Bonito, MS } \\
\text { UTM: 544652; } 7650534\end{array}$} & \multirow{8}{*}{$\begin{array}{l}\text { Giselle } \\
\text { Utida }\end{array}$} & 1 ao 5 & Gastrópodes indeterminados \\
\hline & & & & & 7 & Gastrópode do gênero Pomacea \\
\hline & & & & & 8 ao 10 & Gastrópode do gênero Idiopyrgus \\
\hline & & & & & 11 ao 24,49 & Gastrópode do gênero Biomphalaria \\
\hline & & & & & 51 & Gastrópode do gênero Pomacea \\
\hline & & & & & 27 ao 35,40 ao 48,52 ao 59 & Fragmentos de gastrópodes \\
\hline & & & & & 36 & Fragmentos de talos de algas caraceas \\
\hline & & & & & 60 & Fragmento vegetal \\
\hline \multirow{8}{*}{4072} & \multirow{8}{*}{ C1,5-2,0-B } & \multirow{8}{*}{4,46} & \multirow{8}{*}{$\begin{array}{c}\text { Formação Xaraiés, } \\
\text { Mineração Calcário Xaraés, } \\
\text { Bonito, MS } \\
\text { UTM: 544652; } 7650534\end{array}$} & \multirow{8}{*}{$\begin{array}{l}\text { Giselle } \\
\text { Utida }\end{array}$} & 267 & Ectrutura olobular \\
\hline & & & & & $\frac{2,6,7}{3}$ & $\begin{array}{l}\text { Estrutura globular } \\
\text { Fragmento de ostracode }\end{array}$ \\
\hline & & & & & 5 & Fragmento vegetal \\
\hline & & & & & 13,14 & Fragmento vegetal \\
\hline & & & & & $15,16,27$ & Estruturas globulares \\
\hline & & & & & 26 & Fragmento de girogonite \\
\hline & & & & & 25 & estruturas revestidas por carbonato \\
\hline & & & & & & Diversos fragmentos de carapaças \\
\hline
\end{tabular}




\begin{tabular}{|c|c|c|c|c|c|c|}
\hline \multirow{2}{*}{ GP/5E } & \multirow{2}{*}{ Amostras } & \multirow{2}{*}{$\begin{array}{l}\text { Posição no } \\
\text { perfil (m) }\end{array}$} & \multicolumn{4}{|c|}{ ANEXO G cont. } \\
\hline & & & Proveniência & Coletor & Quadrantes & Descrição \\
\hline & & & & & & \\
\hline \multirow{6}{*}{4073} & \multirow{6}{*}{ C1,0-1,5 } & \multirow{6}{*}{ 3,96 } & \multirow{6}{*}{$\begin{array}{c}\text { Formação Xaraiés, } \\
\text { Mineração Calcário Xaraés, } \\
\text { Bonito, MS } \\
\text { UTM: } 544652 ; 7650534\end{array}$} & \multirow{6}{*}{$\begin{array}{l}\text { Giselle } \\
\text { Utida }\end{array}$} & $1,3,6,11$ & fragmentos de ostracodes \\
\hline & & & & & $4,8,13$ ao 16 & matéria orgânica \\
\hline & & & & & $5,7,9,10,12$ & \begin{tabular}{|l|} 
estruturas globulares \\
\end{tabular} \\
\hline & & & & & 37 ao 39,49 ao 51 & fragmentos vegetais \\
\hline & & & & & 25 ao $27,54,55,59,60$ & gastrópodes do gênero Biomphalaria \\
\hline & & & & & $40,41,52,53$ & estruturas tubulares recobertas por carbonato \\
\hline & & & & & & \\
\hline \multirow{4}{*}{4074} & \multirow{4}{*}{$\mathrm{C} 0,5-1,0-\mathrm{A}$} & \multirow{4}{*}{3,46} & \multirow{4}{*}{$\begin{array}{c}\text { Formação Xaraiés, } \\
\text { Mineração Calcário Xaraés, } \\
\text { Bonito, MS } \\
\text { UTM: 544652; } 7650534\end{array}$} & \multirow{4}{*}{$\begin{array}{l}\text { Giselle } \\
\text { Utida }\end{array}$} & 1,2 & gastrópodes indeterminados \\
\hline & & & & & 3 ao 12,21 ao 24,27 & gastrópodes do gênero Biomphalaria \\
\hline & & & & & 13 ao 19 & fragmento vegetal \\
\hline & & & & & 28 ao 31,37 ao 43,49 ao 55 & fragmento de gastrópodes \\
\hline & & & & & & \\
\hline \multirow{5}{*}{4075} & \multirow{5}{*}{ C0,5-1,0-B } & \multirow{5}{*}{3,46} & \multirow{5}{*}{$\begin{array}{c}\text { Formação Xaraiés, } \\
\text { Mineração Calcário Xaraés, } \\
\text { Bonito, MS } \\
\text { UTM: 544652; } 7650534\end{array}$} & \multirow{5}{*}{$\begin{array}{l}\text { Giselle } \\
\text { Utida }\end{array}$} & 2 & gastrópode do gênero Biomphalaria \\
\hline & & & & & 3,8 & fragmentos de gastrópodes \\
\hline & & & & & 4 ao 6 & fragmento de vegetais \\
\hline & & & & & 7 & estrutura globular \\
\hline & & & & & 10 & fragmentos de ostracodes \\
\hline & & & & & & \\
\hline \multirow{6}{*}{4076} & \multirow{6}{*}{$\mathrm{C} 0,0-0,5$} & \multirow{6}{*}{2,96} & \multirow{6}{*}{$\begin{array}{c}\text { Formação Xaraiés, } \\
\text { Mineração Calcário Xaraés, } \\
\text { Bonito, MS } \\
\text { UTM: 544652; } 7650534\end{array}$} & \multirow{6}{*}{$\begin{array}{l}\text { Giselle } \\
\text { Utida }\end{array}$} & $1,4,5,8,9$ & fragmentos de ostracodes \\
\hline & & & & & 6,12 & matéria orgânica \\
\hline & & & & & 10,27 & Gastrópode indeterminado \\
\hline & & & & & 25 & Gastrópodes do gênero Acrobis \\
\hline & & & & & 28 aо 32 & Gastrópodes do gênero Biomphalaria \\
\hline & & & & & 49,50 & fragmentos de gastrópodes \\
\hline \multirow{8}{*}{4077} & \multirow{8}{*}{ Т30-38 } & \multirow{8}{*}{2,36} & \multirow{8}{*}{$\begin{array}{c}\text { Formação Xaraiés, } \\
\text { Mineração Calcário Xaraés, } \\
\text { Bonito, MS } \\
\text { UTM: 544652; } 7650534\end{array}$} & & $1,13,25,39,40,51,52$ & fragmentos de ostracodes \\
\hline & & & & & 2 ao $4,14,16$ ao 18 & estruturas globulares \\
\hline & & & & & 37,42 & gastrópodes do gênero Acrobis \\
\hline & & & & & 26 & estruturas vegetais \\
\hline & & & & Utida & $23,49,50$ & estruturas revestidas por carbonato \\
\hline & & & & & $\begin{array}{c}8 \text { ao } 12,20 \text { ao } 24,24,32 \text { ao } 36,44 \\
\text { ao } 48,56 \text { ao } 60\end{array}$ & fragmentos de gastrópodes \\
\hline & & & & & 54 & gastrópode do gênero Idiopyrgus \\
\hline & & & & & 43 ao 55 & gastrópodes do gênero Biomphalaria \\
\hline & & & & & & \\
\hline
\end{tabular}




\begin{tabular}{|c|c|c|c|c|c|c|}
\hline \multirow{2}{*}{ GP/5E } & \multirow{2}{*}{ Amostras } & \multirow{2}{*}{$\begin{array}{l}\text { Posição no } \\
\text { perfil (m) }\end{array}$} & \multicolumn{4}{|c|}{ ANEXO G cont. } \\
\hline & & & Proveniência & Coletor & Quadrantes & Descrição \\
\hline & & & & & & \\
\hline \multirow{16}{*}{4078} & \multirow{16}{*}{ T48-58-A } & \multirow{16}{*}{2,18} & \multirow{16}{*}{$\begin{array}{c}\text { Formação Xaraiés, } \\
\text { Mineração Calcário Xaraés, } \\
\text { Bonito, MS } \\
\text { UTM: 544652; } 7650534\end{array}$} & \multirow{16}{*}{$\begin{array}{l}\text { Giselle } \\
\text { Utida }\end{array}$} & $1,4,8$ & provaveis espículas de porifera de água doce e estruturas globulares \\
\hline & & & & & $2,6,11$ & fragmentos de ostracodes \\
\hline & & & & & $7,35,36$ & ostracodes do gênero Cypria e Candona \\
\hline & & & & & 16 & prováveis espículas de porifera de água doce \\
\hline & & & & & 18 & fragmentos de girogonites \\
\hline & & & & & 19 & gastrópodes do gênero Acrobis \\
\hline & & & & & 20 & gastrópode da Família Hydrobiidae \\
\hline & & & & & 21,22 & gastrópodes do gênero Biomphalaria \\
\hline & & & & & $23,31,37$ ao 52 & fragmentos de ostracodes \\
\hline & & & & & 26 & Ostracodes do gênero Ilyocypris \\
\hline & & & & & 25,29 & Ostracodes da espécie Wolburgiopsis chinamuertensis \\
\hline & & & & & 27,28 & Ostracodes do gênero Cypria \\
\hline & & & & & 30 & Ostracode do gênero Darwinula \\
\hline & & & & & 49 & fragmentos de gastrópodes \\
\hline & & & & & 43,44 & matéria orgânica \\
\hline & & & & & 57 ao 60 & estruturas recobertas por carbonato \\
\hline & & & & & & \\
\hline \multirow{4}{*}{4079} & \multirow{4}{*}{ T48-58-B } & \multirow{4}{*}{2,18} & \multirow{4}{*}{$\begin{array}{c}\text { Formação Xaraiés, } \\
\text { Mineração Calcário Xaraés, } \\
\text { Bonito, MS } \\
\text { UTM: 544652; } 7650534\end{array}$} & \multirow{4}{*}{$\begin{array}{l}\text { Giselle } \\
\text { Utida }\end{array}$} & 1,2 & fragmentos de ostracodes \\
\hline & & & & & 3,4 & gastrópodes do gênero Biomphalaria \\
\hline & & & & & 5,25 ao 44 & fragmentos de gastrópodes \\
\hline & & & & & 6 ao 11 & fragmentos de algas caraceas \\
\hline & & & & & & \\
\hline \multirow{12}{*}{4080} & \multirow{12}{*}{ T58-63 } & \multirow{12}{*}{2,08} & \multirow{12}{*}{$\begin{array}{c}\text { Formação Xaraiés, } \\
\text { Mineração Calcário Xaraés, } \\
\text { Bonito, MS } \\
\text { UTM: 544652; } 7650534\end{array}$} & \multirow{12}{*}{$\begin{array}{l}\text { Giselle } \\
\text { Utida }\end{array}$} & $5,11,12,18,19,29$ & fragmentos de ostracodes \\
\hline & & & & & $1,8,10$ & estruturas globulares \\
\hline & & & & & 4 & estruturas tubulares revestidas por carbonato \\
\hline & & & & & 9,16 & fragmento de girogonite \\
\hline & & & & & 14 & gastrópodes do gênero Acrobis e 1 indivíduo jovem de Biomphalaria \\
\hline & & & & & $20,21,49,50$ & fragmentos de talos de caraceas \\
\hline & & & & & 25 & gastrópode indeterminado \\
\hline & & & & & 26 & gastrópodes do gênero Acrobis \\
\hline & & & & & 27 & gastrópodes do gênero Biomphalaria \\
\hline & & & & & 28 & girogonite indeterminado \\
\hline & & & & & 51 ao 53 & fragmentos de conchas? \\
\hline & & & & & 48,54 ao 60 & fragmentos de gastrópodes \\
\hline & & & & & & \\
\hline
\end{tabular}




\begin{tabular}{|c|c|c|c|c|c|c|}
\hline \multirow{2}{*}{ GP/5E } & \multirow{2}{*}{ Amostras } & \multirow{2}{*}{$\begin{array}{l}\text { Posição no } \\
\text { perfil (m) }\end{array}$} & \multicolumn{4}{|c|}{ ANEXO G cont. } \\
\hline & & & Proveniência & Coletor & Quadrantes & Descrição \\
\hline & & & & & & \\
\hline \multirow{9}{*}{4081} & \multirow{9}{*}{$\mathrm{T} 72-82$} & \multirow{9}{*}{1,94} & \multirow{9}{*}{$\begin{array}{c}\text { Formação Xaraiés, } \\
\text { Mineração Calcário Xaraés, } \\
\text { Bonito, MS } \\
\text { UTM: 544652; } 7650534\end{array}$} & \multirow{9}{*}{$\begin{array}{l}\text { Giselle } \\
\text { Utida }\end{array}$} & $4,5,10,16$ & Fragmentos de ostracodes \\
\hline & & & & & 39 ao 44,51 ao 56 & Fragmentos de gastrópodes \\
\hline & & & & & 3 & Fragmento de matéria orgânica \\
\hline & & & & & $6,7,25$ & Fragmentos de girogonites \\
\hline & & & & & 8,9 & Estruturas globulares \\
\hline & & & & & 11 & Gastrópodes indeterminados e do gênero Acrobis \\
\hline & & & & & 12 & Girogonites indeterminados \\
\hline & & & & & 14,15 & Fragmentos de talos de algas caraceas \\
\hline & & & & & $37,38,49,50$ & Fragmentos diversos \\
\hline & & & & & & \\
\hline \multirow{7}{*}{4082} & \multirow{7}{*}{ T128-134 } & \multirow{7}{*}{1,38} & \multirow{7}{*}{$\begin{array}{c}\text { Formação Xaraiés, } \\
\text { Mineração Calcário Xaraés, } \\
\text { Bonito, MS } \\
\text { UTM: 544652; } 7650534\end{array}$} & \multirow{7}{*}{$\begin{array}{l}\text { Giselle } \\
\text { Utida }\end{array}$} & 1,2 & Estruturas globulares \\
\hline & & & & & 3 ao $5,7,8,10$ & Fragmentos de ostracodes \\
\hline & & & & & 9,15 & Gastrópodes do gênero Biomphalaria \\
\hline & & & & & $12,27,28,37$ ao 41,49 & Talos de algas caraceas \\
\hline & & & & & 13,14 & Ostracodes sp. 5 \\
\hline & & & & & 16,17 & Fragmentos de gastrópodes \\
\hline & & & & & 50,54 & Fragmentos de folhas? \\
\hline & & & & & & \\
\hline \multirow{6}{*}{4083} & \multirow{6}{*}{ T160-170 } & \multirow{6}{*}{1,06} & \multirow{6}{*}{$\begin{array}{c}\text { Formação Xaraiés, } \\
\text { Mineração Calcário Xaraés, } \\
\text { Bonito, MS } \\
\text { UTM: 544652; } 7650534\end{array}$} & \multirow{6}{*}{$\begin{array}{l}\text { Giselle } \\
\text { Utida }\end{array}$} & 49 ao 51 & Grãos cobertos por carbonato \\
\hline & & & & & 52 & Fragmentos de gastrópodes \\
\hline & & & & & $27,37,40$ & Fragmentos de ostracodes \\
\hline & & & & & 38 & Fragmentos de talos de caraceas \\
\hline & & & & & 39 & Fragmentos de gastrópodes \\
\hline & & & & & 25 & Estruturas tubulares \\
\hline & & & & & & \\
\hline \multirow{4}{*}{4084} & \multirow{4}{*}{$\mathrm{T} 215-244$} & \multirow{4}{*}{0,51} & \multirow{4}{*}{$\begin{array}{c}\text { Formação Xaraiés, } \\
\text { Mineração Calcário Xaraés, } \\
\text { Bonito, MS } \\
\text { UTM: 544652; } 7650534 \\
\end{array}$} & \multirow{4}{*}{$\begin{array}{l}\text { Giselle } \\
\text { Utida }\end{array}$} & 49 ao 54 & Grãos revestidos por carbonato \\
\hline & & & & & 55 & Fragmentos de gastrópodes \\
\hline & & & & & $13,26,27$ & Fragmentos de ostracodes \\
\hline & & & & & 28 & Carapaças diversas \\
\hline & & & & & & \\
\hline \multirow{3}{*}{4085} & \multirow{3}{*}{ T259-266 } & \multirow{3}{*}{0,01} & \multirow{3}{*}{$\begin{array}{c}\text { Formação Xaraiés, } \\
\text { Mineração Calcário Xaraés, } \\
\text { Bonito, MS } \\
\text { UTM: 544652; 7650534 }\end{array}$} & & 9,10 & Estrutura em forma de feijão recoberta por carbonato \\
\hline & & & & $\begin{array}{l}\text { Giselle } \\
\text { Utida }\end{array}$ & 11 ao 16 & Grãos recobertos por carbonato \\
\hline & & & & & 17,19 & Fragmentos de ostracodes \\
\hline
\end{tabular}




\begin{tabular}{|c|c|c|c|c|c|}
\hline \multirow{2}{*}{ GP/5E } & \multirow{2}{*}{ Amostra } & \multicolumn{4}{|r|}{ ANEXO H } \\
\hline & & Proveniência & Coletor & Quadrantes & Descrição \\
\hline \multirow{12}{*}{4086} & \multirow{12}{*}{ 07TUF04A-A } & \multirow{12}{*}{$\begin{array}{l}\text { Formação Xaraiés, } \\
\text { Rio Mimoso, Bonito, MS } \\
\text { UTM: 551813; } 7677369\end{array}$} & \multirow{12}{*}{$\begin{array}{l}\text { Giselle } \\
\text { Utida }\end{array}$} & 1 ao 3 & Girogonites do gênero Chara,forma 1, 2,3 e indeterminados \\
\hline & & & & 4 & Estrutura acicular semelhante a uma espícula de porifera \\
\hline & & & & 5 ao 12,14 & Ostracodes diversos, gêneros Darwinula, sp. 1, sp. 4 e não identificados \\
\hline & & & & 15 & Gastrópode não identificado \\
\hline & & & & 16 ao 20 & Gastrópodes do gênero Acrobis \\
\hline & & & & 21,22 & Fragmentos de ostracodes \\
\hline & & & & 23,24 & Estruturas globulares e fragmentos de insetos \\
\hline & & & & 25 aо 32 & Fragmentos de talos de caraceas \\
\hline & & & & 33 ao 35 & Ostracodes diversos, gêneros Darwinula, sp. 1, sp. 4 e não identificados \\
\hline & & & & 37 ao 39,41 & Fragmentos de ostracodes \\
\hline & & & & 36 & Estruturas não identificadas \\
\hline & & & & 41 & Estruturas globulares \\
\hline & & & & & \\
\hline \multirow{12}{*}{4087} & \multirow{12}{*}{ 07TUF04A-B } & \multirow{12}{*}{$\begin{array}{c}\text { Formação Xaraiés, } \\
\text { Rio Mimoso, Bonito, MS } \\
\text { UTM: 551813; } 7677369\end{array}$} & \multirow{12}{*}{$\begin{array}{l}\text { Giselle } \\
\text { Utida }\end{array}$} & 1 & Estrutura acicular, semelhante a uma espícula de porifera \\
\hline & & & & 2 & Ostracodes diversos, gêneros Darwinula, sp. 1, sp. 4 e não identificados \\
\hline & & & & 3 & Fragmentos de ostracodes \\
\hline & & & & 4 & Girogonites do gênero Chara, forma 1, 2, 3 e indeterminados \\
\hline & & & & 5 & Bivalve do gênero Psidium \\
\hline & & & & 6 ao 10 & Fragmentos de bivalves \\
\hline & & & & 11 & Gastrópode da Família Ancylidae \\
\hline & & & & 12 & Fragmentos de ostracodes \\
\hline & & & & 13 ao 21,23 & Gastrópodes do gênero Biomphalaria \\
\hline & & & & 25 & Gastrópode da Família Charopidae \\
\hline & & & & 26 ao 34 & Gastrópodes da Família Hydrobiidae \\
\hline & & & & 37 ao 60 & Fragmentos de gastrópodes \\
\hline & & \multirow{6}{*}{$\begin{array}{l}\text { Formação Xaraiés, } \\
\text { Rio Mimoso, Bonito, MS } \\
\text { UTM: 551813; } 7677369\end{array}$} & \multirow{6}{*}{$\begin{array}{l}\text { Giselle } \\
\text { Utida }\end{array}$} & & \\
\hline \multirow{5}{*}{4088} & \multirow{5}{*}{ 07TUF04A-C } & & & 1 ao 12 & Fragmentos de gastrópodes \\
\hline & & & & 13 ao 22 & Fragmentos de talos de caraceas \\
\hline & & & & 23 & Grãos recobertos de carbonato \\
\hline & & & & $24,25,27$ ao 31 & Fragmentos de vegetais \\
\hline & & & & 26 & Ostracodes indeterminados fixos na matriz \\
\hline & & & & & \\
\hline & & & & & \\
\hline
\end{tabular}




\begin{tabular}{|c|c|c|c|c|c|}
\hline \multirow{2}{*}{ GP/5E } & \multirow{2}{*}{ Amostra } & \multicolumn{4}{|c|}{ ANEXO H cont. } \\
\hline & & Proveniência & Coletor & Quadrantes & Descrição \\
\hline & & & & & \\
\hline \multirow{9}{*}{4089} & \multirow{9}{*}{ 07TUF06A-A } & \multirow{9}{*}{$\begin{array}{c}\text { Formação Xaraiés, } \\
\text { Rio Mimoso, Bonito, MS } \\
\text { UTM: 551846; } 7677392\end{array}$} & \multirow{9}{*}{$\begin{array}{l}\text { Giselle } \\
\text { Utida }\end{array}$} & 1 ao 3 & Estruturas vegetais e animais provavelmente atuais \\
\hline & & & & 4 & Bivalve do gênero Psidium \\
\hline & & & & 5,6 & Fragmentos de bivalve \\
\hline & & & & 7 & $\begin{array}{l}\text { Gastrópode da Família Subulinidae, SubFamília Subulininae, Família e Gênero } \\
\text { Indeterminados }\end{array}$ \\
\hline & & & & 8 aо 32 & Gastrópodes da Família Hydrobiidae \\
\hline & & & & 33 ao 37,39 ao 43 & Gastrópodes do gênero Biomphalaria \\
\hline & & & & 38,44 & Gastrópode indeterminado \\
\hline & & & & 45 ao 48 & Estruturas tubulares \\
\hline & & & & 49 ao 60 & Fragmentos vegetais \\
\hline & & \multirow{3}{*}{$\begin{array}{c}\text { Formação Xaraiés, } \\
\text { Rio Mimoso, Bonito, MS } \\
\text { UTM: 551846; 7677392 }\end{array}$} & & & \\
\hline \multirow{2}{*}{4090} & \multirow{2}{*}{ 07TUF06A-B } & & \multirow{2}{*}{$\begin{array}{l}\text { Giselle } \\
\text { Utida }\end{array}$} & 1 ao 14 & Fragmentos vegetais \\
\hline & & & & 15 ao 57 & Fragmentos de conchas \\
\hline & & & & & \\
\hline \multirow{6}{*}{4091} & \multirow{6}{*}{ 07TUF06A-C } & \multirow{6}{*}{$\begin{array}{c}\text { Formação Xaraiés, } \\
\text { Rio Mimoso, Bonito, MS } \\
\text { UTM: 551846; } 7677392\end{array}$} & \multirow{6}{*}{$\begin{array}{l}\text { Giselle } \\
\text { Utida }\end{array}$} & 1 & Gastrópode da Família Hydrobiidae \\
\hline & & & & 2 & Fragmentos vegetais \\
\hline & & & & 3 & Estruturas tubulares \\
\hline & & & & 4 & Fragmentos de bivalves \\
\hline & & & & 5 ao 7 & Fragmentos de carapaças diversas \\
\hline & & & & 8 ao 55 & Fragmentos de moluscos \\
\hline & & & & & \\
\hline \multirow{14}{*}{4092} & \multirow{14}{*}{ 07TUF06A-D } & \multirow{14}{*}{$\begin{array}{c}\text { Formação Xaraiés, } \\
\text { Rio Mimoso, Bonito, MS } \\
\text { UTM: 551846; } 7677392\end{array}$} & \multirow{14}{*}{$\begin{array}{l}\text { Giselle } \\
\text { Utida }\end{array}$} & 1 ao 4 & Girogonites do gênero Chara formas 1, 2 e 3 \\
\hline & & & & 5 ao 7 & Gastrópodes do gênero Acrobis \\
\hline & & & & 8 & Fragmentos de carapaças diversas \\
\hline & & & & 9 & Possível espícula de porifera \\
\hline & & & & 10 & Fragmentos de girogonites \\
\hline & & & & 13 ao 17 & Estruturas globulares \\
\hline & & & & 18,19 & Estruturas vegetais possivelmente atuais \\
\hline & & & & $11,20,21$ ao 25 & Fragmentos diversos de invertebrados \\
\hline & & & & 26 & Fragmentos de talos de caraceas \\
\hline & & & & & Muito fragmento vegetal na lâmina \\
\hline & & & & 29 & Ostracodes do gênero Candona \\
\hline & & & & 30,31 & Fragmentos de diversas carapaças \\
\hline & & & & 32 ao 36 & Estruturas globulares, possivelmente fungos \\
\hline & & & & 38 & estruturas globulares \\
\hline
\end{tabular}




\begin{tabular}{|c|c|c|c|c|c|}
\hline \multirow{2}{*}{ GP/5E } & \multirow{2}{*}{ Amostra } & \multicolumn{4}{|c|}{ ANEXO H cont. } \\
\hline & & Proveniência & Coletor & Quadrantes & Descrição \\
\hline & \multirow{7}{*}{ 07TUF07A-A } & & & & \\
\hline \multirow{6}{*}{4093} & & \multirow{6}{*}{$\begin{array}{l}\text { Formação Xaraiés, } \\
\text { Rio Seputa, Bonito, MS } \\
\text { UTM: 526992; 7670727 }\end{array}$} & \multirow{6}{*}{$\begin{array}{l}\text { Giselle } \\
\text { Utida }\end{array}$} & 1 & Ostracodes sp. 5 \\
\hline & & & & 2 & Fragmentos de ostracodes \\
\hline & & & & 3 ao 7 & Gastrópodes do gênero Biomphalaria \\
\hline & & & & 8 & Fragmentos de gastrópodes \\
\hline & & & & 9 ao 19 & Fragmentos de talos de caraceas \\
\hline & & & & 20 aо 30 & Placas recobertas de carbonato \\
\hline & & & & & \\
\hline \multirow{9}{*}{4094} & \multirow{9}{*}{ 07TUF07A-B } & \multirow{9}{*}{$\begin{array}{l}\text { Formação Xaraiés, } \\
\text { Rio Seputa, Bonito, MS } \\
\text { UTM: 526992; 7670727 }\end{array}$} & \multirow{9}{*}{$\begin{array}{l}\text { Giselle } \\
\text { Utida }\end{array}$} & 1 ao 12 & Girogonites do gênero Chara, os recobertos por carbonato são da forma 4 \\
\hline & & & & 15 & Fragmentos de gastrópodes \\
\hline & & & & $13,14,16$ & Estruturas diversas não identificadas \\
\hline & & & & 17,18 & Fragmentos de ostracodes \\
\hline & & & & 19 ao 31 & Estruturas recobertas por carbonato, algumas semelhantes a ostracodes \\
\hline & & & & 32,33 & Fragmentos de ostracodes, muito frágeis, posívelmente jovens \\
\hline & & & & 34 & Estruturas globulares \\
\hline & & & & 35,43 & Fragmentos de girogonites \\
\hline & & & & 37 ao 42,44 & Fragmentos de ostracodes \\
\hline & & & & & \\
\hline \multirow{9}{*}{4095} & \multirow{9}{*}{ 07TUF14A--A } & \multirow{9}{*}{$\begin{array}{c}\text { Formação Xaraiés, } \\
\text { Rio Campina, Bonito, MS } \\
\text { UTM: 529466; } 7728054\end{array}$} & \multirow{9}{*}{$\begin{array}{l}\text { Giselle } \\
\text { Utida }\end{array}$} & 1 & Estruturas globulares, provaveis fungos atuais \\
\hline & & & & 2 & Ostracode \\
\hline & & & & 3 & Gastrópodes do gênero Acrobis \\
\hline & & & & 5 & Fragmentos de gastrópodes \\
\hline & & & & 6 & Estruturas tubulares, fragmentos de talos de caraceas \\
\hline & & & & $4,7,8$ & Estruturas atuais \\
\hline & & & & 9,15 & Fragmentos de ostracodes \\
\hline & & & & 10,13 & Estruturas globulares \\
\hline & & & & 12 & Estruturas globulares, provaveis fungos \\
\hline \multirow{10}{*}{4096} & \multirow{10}{*}{ 07TUF14A-B } & \multirow{10}{*}{$\begin{array}{c}\text { Formação Xaraiés, } \\
\text { Rio Campina, Bonito, MS } \\
\text { UTM: 529466; } 7728054\end{array}$} & \multirow{10}{*}{$\begin{array}{l}\text { Giselle } \\
\text { Utida }\end{array}$} & & \\
\hline & & & & $\frac{2}{3}$ & $\begin{array}{l}\text { Estruturas vegetais } \\
\text { Estruturas globulares, provaveis fungos }\end{array}$ \\
\hline & & & & 4 ao 6 & Grãos revestidos por carbonato \\
\hline & & & & 7 & Gastrópodes da Família Hydrobiidae \\
\hline & & & & $9,10,12$ & Gastrópodes não identificados \\
\hline & & & & 11 & Gastrópodes do gênero Acrobis \\
\hline & & & & 13 ао 21 & Gastrópodes da Família Hydrobiidae \\
\hline & & & & 22 ao 24,28 ao 50 & Fragmentos de gastrópodes \\
\hline & & & & 25 ао 26 & Fragmentos de bivalves \\
\hline & & & & 27 & Fragmentos de carapaças \\
\hline
\end{tabular}




\begin{tabular}{|c|c|c|c|c|c|}
\hline \multirow{2}{*}{ GP/5E } & \multirow{2}{*}{ Amostra } & \multicolumn{4}{|c|}{ ANEXO H cont. } \\
\hline & & Proveniência & Coletor & Quadrantes & Descrição \\
\hline & & & & & \\
\hline \multirow{5}{*}{4097} & \multirow{5}{*}{ 07TUF16B-A } & \multirow{5}{*}{$\begin{array}{l}\text { Formação Xaraiés, } \\
\text { Antiga mineração de } \\
\text { carbonatos, Centro Bonito, MS } \\
\text { UTM: 552247; } 7665262\end{array}$} & \multirow{5}{*}{$\begin{array}{c}\text { Giselle } \\
\text { Utida }\end{array}$} & 2 & Gastrópodes do gênero Biomphalaria \\
\hline & & & & 1,3 ao 7 & Gastrópodes indeterminados \\
\hline & & & & 8 aо 27 & Fragmentos de gastrópodes \\
\hline & & & & 28 ao 30 & Estruturas recobertas por carbonato \\
\hline & & & & 40 & Fragmentos de insetos atuais \\
\hline & & & & & \\
\hline \multirow{9}{*}{4098} & \multirow{9}{*}{ 07TUF16B-B } & \multirow{9}{*}{$\begin{array}{l}\text { Formação Xaraiés, } \\
\text { Antiga mineraçã̃o de } \\
\text { carbonatos, Centro Bonito, MS } \\
\text { UTM: 552247; } 7665262\end{array}$} & \multirow{9}{*}{$\begin{array}{l}\text { Giselle } \\
\text { Utida }\end{array}$} & 1 & Possíveis ostracodes recobertos por carbonato \\
\hline & & & & 2,3 & Ostracodes indeterminados \\
\hline & & & & $5,14,25,26$ & Fragmentos de ostracodes \\
\hline & & & & 6 & Gastrópode do gênero Biomphalaria \\
\hline & & & & $7,8,15$ & Estruturas globulares, possíveis Helizoas \\
\hline & & & & 9,16 & Estruturas globulares, possíveis fungos \\
\hline & & & & 10 & Estruturas vegetais \\
\hline & & & & $11,12,17$ & Fragmentos de insetos atuais \\
\hline & & & & 27 & Estruturas globulares diversas \\
\hline & & & & & \\
\hline \multirow{4}{*}{4099} & \multirow{4}{*}{ 07TUF16D-A } & \multirow{4}{*}{$\begin{array}{l}\text { Formação Xaraiés, } \\
\text { Antiga mineração de } \\
\text { carbonatos, Centro Bonito, MS } \\
\text { UTM: 552247; } 7665262\end{array}$} & \multirow{4}{*}{$\begin{array}{c}\text { Giselle } \\
\text { Utida }\end{array}$} & $1,2,4,5$ & Gastrópodes do gênero Biomphalaria \\
\hline & & & & 3 & Gastrópode indeterminado \\
\hline & & & & 6 ao 30 & Fragmentos de gastrópodes \\
\hline & & & & 31 ao 38 & Estruturas revestidas por carbonato \\
\hline & & & & & \\
\hline \multirow{3}{*}{4100} & \multirow{3}{*}{ 07TUF16D-B } & \multirow{3}{*}{$\begin{array}{c}\text { Formação Xaraiés, } \\
\text { Antiga mineração de } \\
\text { carbonatos, Centro Bonito, MS } \\
\text { UTM: 552247; 7665262 }\end{array}$} & \multirow{3}{*}{$\begin{array}{l}\text { Giselle } \\
\text { Utida }\end{array}$} & 2 & Fragmentos e talos de caraceas \\
\hline & & & & 3,4 & Fragmentos diversos \\
\hline & & & & 5,6 & Fragmentos e ostracodes e uma estrutura globular \\
\hline
\end{tabular}

